\title{
Juan Pivel Devoto y la Colección de clásicos uruguayos como constructora de un canon literario nacional (1953-1982)
}

Universidad Nacional de La Plata, Doctorado en Letras

Candidato: Mag. Néstor J. Gutiérrez

Directora de Tesis: Dra. Alejandra Mailhe

Codirector: Dr. Luis Delio Machado 
A mi padre, mi primer lector 
ÍNDICE

Introducción

Capítulo 1: Estado de la cuestión

Capítulo 2: Las primeras empresas editoriales y el desarrollo del mercado editorial

Capítulo 3: Como Pivel no hay. Un intelectual al servicio del Estado nacional

Capítulo 4: La forma del libro

Capítulo 5 «Prólogos de la Colección...»

Capítulo 6: El cielo canónico uruguayo y la Colección...

Capítulo 7: Censura y autocensura en la Colección...

Conclusiones generales

Anexos

Bibliografía 


\section{AGRADECIMIENTOS}

Al emprender mi tesis de maestría hace algunos años, entendí que los historiadores uruguayos debían llevar a cabo una diversificación de sus objetos de estudio, saliendo de la historia política, económica y social decimonónica.

Los estudios sobre el libro y la edición implican perspectivas innovadoras que permiten comprender mucho mejor la historia cultural e intelectual a nivel nacional y regional. En Argentina encontré un campo en pleno desarrollo y con resultados que en Uruguay no existían. Durante el II Coloquio Argentino de Estudios sobre el Libro y la Edición (2016), realizado en Córdoba, me encontré con Alejandra Torres Torres, quien tenía los mismos intereses que yo; lo extraño es que el germen del primer grupo de investigación uruguayo sobre el libro y la edición se conoció en Argentina.

En este inicio/cierre, quisiera agradecer especialmente a quienes me permitieron llevar adelante este trabajo. Inicialmente quiero agradecer a mi tutora argentina la Dra. Alejandra Mailhe, quien me recibió cálidamente durante múltiples tardes en su hogar. Gracias a sus consejos y correcciones — con mucha paciencia — pude hacerme preguntas de las que no había reparado sobre mi propio objeto de estudio. Sin su dirección, mucho de lo que aquí se va a leer no existiría.

Posteriormente, doy las gracias y dedico también esta tesis a mi tutor uruguayo, el Dr. Luis Delio Machado, quien me animó a seguir el programa de doctorado en La Plata y por quien sentí una alta estima intelectual.

También quiero agradecer a la Universidad Nacional de La Plata, que me permitió ingresar a su programa de doctorado, cumpliendo y superando ampliamente con mis expectativas académicas.

A los trabajadores de los archivos y bibliotecas que consulté en estos años — Biblioteca Nacional y Archivo General de la Nación (AGNU) de Uruguay, Centro de Documentación y Biblioteca Pivel Devoto de la Universidad de Montevideo, Universidad de la República e Instituto de Profesores Artigas-; sin su profesionalidad y amabilidad hubiera sido imposible bucear entre tantas hojas y ríos de tinta.

A mis compañeros de investigación del Grupo (Inter) disciplinario de Estudios sobre el Campo Historiográfico-Editorial (GIECHE) Leonardo Guedes y Alejandra Torres Torres, que siempre estuvieron dispuestos a intercambiar bibliografía, opiniones y soluciones a diversos problemas que se nos fueron presentando tanto individual como grupalmente.

A mis colegas y amigos Silvana Espiga, Alfredo Alpini, Laura de la Rosa y Juan Felártigas, que en las interminables charlas sobre historia, literatura y otras misceláneas, 
muchas veces sin saberlo, me dejaron pensando en aquello sobre lo que estuve trabajando en estos años.

En lo personal, agradezco a mi madre y a mi hermana, que fueron apoyos constantes en este proceso, y eternas interesadas en cómo venían mis estudios. 


\section{INTRODUCCIÓN}

Esta tesis de doctorado se propuso llevar adelante una investigación centrada en dos protagonistas: la Colección de Clásicos Uruguayos y Juan E. Pivel Devoto. En el caso de Uruguay, estamos frente a un trabajo innovador que tiene como objeto de estudio la Colección..., aspecto que hasta el momento no ha sido abordado en profundidad. Respecto a la mencionada serie de libros, consideramos que debido a sus características — que observaremos oportunamente- se pretendió llevar a cabo, por parte del Estado a través de este proyecto editorial, una selección de publicaciones canónicas en materia literaria e historiográfica principalmente.

Respecto a la figura de Pivel, podemos definirlo como un protagonista - historiador, funcionario del Estado, militante político, editor, intelectual, profesor, y tantos otros roles más - que está presente directa o indirectamente en todo el trabajo. Cada documento y cada proyecto encarnado en la Colección ... parece haber sido pensado por él.

Iniciaremos esta tesis reseñando los principales estudios historiográficos y literarios que nos permitieron desarrollar nuestra investigación. Posteriormente, en el capítulo 2, «Las primeras empresas editoriales y el desarrollo del mercado editorial», realizaremos un repaso desde la gestación del campo intelectual uruguayo hasta la aparición de los primeros editores encargados de iniciar la producción libresca en el país hacia fines del siglo XIX, desde el pionero Antonio Barreiro y Ramos, pasando por otros empresarios gallegos — que tuvieron una amplia tradición editora en el Uruguay, y que dinamizaron la producción libresca en el país-, hasta la aparición de la Colección... En este sentido, pretendemos realizar una revisión panorámica que esclarezca dónde se inscribieron las ediciones estatales.

Luego nos concentraremos en las distintas generaciones literarias (del Ateneo, del Novecientos, del Centenario y Crítica) que fueron protagonistas del catálogo de la Colección..., para estudiar posteriormente la incidencia de cada una de ellas en la conformación del canon nacional, y observar la postura conservadora que el Estado tuvo al hacer ingresar autores generalmente editados antes de 1950. Finalizaremos haciendo referencia al Golpe de Estado de 1973, y la dictadura que cortó el normal desarrollo cultural del Uruguay.

Para el capítulo 3, «Como Pivel no hay. Un intelectual al servicio del Estado nacional», trabajaremos sobre la figura del editor más importante de todo el proyecto editorial estudiado. Recorreremos su biografía, centrándonos en los primeros años del joven Pivel. Nuestro interés 
serán sus primeros trabajos como historiador, atendiendo a las redes intelectuales que le permitieron hacerse con la dirección del Museo Histórico Nacional (MHN), institución que fue su reducto de formación de discípulos y, en donde actuó en favor de su proyecto historiográfico.

Estudiaremos sus años de madurez, mientras trabajaba como funcionario público en puestos administrativos, de forma paralela a su actividad como historiador. Claramente es Pivel uno de los protagonistas fundamentales de nuestro trabajo; por él pasarán cada una de nuestras perspectivas de análisis, ya que, como afirmamos, la nación cultural se construyó bajo su atenta mirada.

Su pasaje como Ministro de Instrucción Pública y Seguridad Social (1963-1967), en el inicio del segundo gobierno colegiado del Partido Nacional, le permitirá hacerse cargo de la Colección... Con su nuevo rol de editor jefe de esa serie de libros, se terminará de dar forma al catálogo, luego de la publicación récord de más de setenta volúmenes en cuatro años.

Finalmente, trabajaremos con un ejemplo de las redes intelectuales creadas por Pivel, luego de ocupar los distintos puestos hegemónicos dentro de la administración estatal, reconstruyendo un concurso de investigación histórica donde el ganador fue su discípulo y colaborador Alfredo Castellanos.

En el capítulo 4, «La forma del libro», estudiaremos en detalle la Colección... Primeramente observaremos cómo se constituyó, por parte del Estado uruguayo, el novel proyecto editorial. Posteriormente, trabajaremos con el catálogo y su confección por parte de la Comisión editora. También haremos hincapié en las características físicas de los volúmenes, e intentaremos reconstruir el círculo de comunicación creado para toda la serie: impresión, distribución y venta, entre otros aspectos.

Además, pretendemos observar las particularidades que se le agregó a la serie de libros estatales, cuando Pivel se hizo cargo de la comisión en los años sesenta. Por ello, la forma que tomó la Colección... no puede separarse del estudio de su editor más importante.

Para el capítulo 5, «Prólogos de la Colección...», realizaremos un análisis de los prólogos de algunas de las obras que integran el catálogo, aquí considerados como dispositivos de conducción de lectura, claves para entender qué se buscaba resaltar, por parte del Estado, para conformar a los nuevos ciudadanos desde el punto de vista cultural.

En este caso, nos centraremos en algunos ejemplos de fuentes historiográficas y literarias. Observaremos cómo Pivel, en su doble tarea de editor y de prologuista, condujo las miradas de los lectores hacia determinados tópicos ligados a su trabajo como historiador. La nación uruguaya fue la meta, y esa construcción cultural fue a imagen y semejanza del proyecto intelectual del propio Pivel. 
En el capítulo 6, «El cielo canónico uruguayo y la Colección ...», tendremos en cuenta los diversos cánones creados por tres tipos de fuentes. Para la crítica literaria, pondremos especial énfasis en la lectura que realizó Carlos Roxlo hacia principios del siglo XX, que sigue siendo una obra de referencia hasta el día de hoy.

También estudiaremos las diferentes colecciones de libros hechas por editores privados que fomentaban la publicación de determinados autores del Uruguay, y los programas de enseñanza secundaria que, desde otro ámbito — público estatal—, pugnaban por integrar algunos autores y libros a la lista. Tanto la elección de obras como los generadores de dichas selecciones, fueron los temas que nos interesaron en este capítulo de manera detallada. Finalmente, reflexionaremos sobre aquellos autores que consideramos integrantes de las «constelaciones canónicas» de Uruguay, considerando cuál fue la relación que tuvieron con la Colección...

Para finalizar, en el capítulo 7, «Censura y autocensura en la Colección ...», analizaremos, a nivel general, cómo se gestaron las selecciones por parte de la Comisión, y cuál fue el rol de Pivel en este punto.

Además, presentaremos tres casos de censura tanto en prólogos de las obras como en autores para integrar el catálogo de la Colección... Señalaremos lo sucedido con la censura al historiador Eduardo Acevedo - junto con algunos otros casos menores_-, y al prologuista Roberto Bula Píriz, amén de considerar la autocensura de Alberto Zum Felde. 


\section{CAPÍTULO 1 \\ ESTADO DE LA CUESTIÓN}

Este trabajo tiene como protagonista a una colección de libros que pretendió construir un canon oficial nacional. Cada una de las palabras que conforman la afirmación anterior supone una serie de interrogantes que la historiografía ya ha tratado.

Con respecto al nacionalismo, consideramos los postulados de Anderson (2011) para pensar la Colección... como parte de la constitución de una comunidad imaginada, tanto de textos sintetizadores de la identidad nacional, como de lectores, aunque en un período posterior a la fundación nacional analizada por este autor.

Nuestra investigación pretende realizar un estudio detallado sobre las formas de producción del nacionalismo dentro del ámbito cultural. Con Anderson, definimos una nación como

...una comunidad políticamente imaginada como inherentemente limitada y soberana. Es imaginada porque aun los miembros de la nación más pequeña no conocerán jamás a la mayoría de sus compatriotas, no los verán ni oirán siquiera hablar de ellos, pero en la mente de cada uno vive la imagen de su comunión (Anderson, 2011, p. 23).

Para explicar el surgimiento de dicha idea, el autor señala que fueron tanto la novela como el periódico los que forjaron dicha comunidad, y es por ello que resalta a todos los «lectores semejantes, a quienes se relacionaba a través de la imprenta, [que] formaron, en su invisibilidad visible, secular, particular, el embrión de la comunidad nacionalmente imaginada» (Anderson, 2011, p. 73). Por ende, las afirmaciones de Anderson nos permiten esclarecer teóricamente el sentido de nuestra investigación, y remarcar su importancia fundamental para comprender la construcción de la nacionalidad desde el ámbito cultural. ${ }^{1}$

Desde un enfoque próximo al de Anderson, apelamos al filósofo Sloterdijk para preguntarnos «¿Qué otra cosa son las naciones modernas sino eficaces fícciones de públicos

\footnotetext{
${ }^{1}$ También tenemos en cuenta la postura de Bhabha (2010), al pensar la nación como una construcción narrativa e ideológica ambivalente, generada como consecuencia de la disputa discursiva constante en el tránsito de la historia. A su vez, pensamos con Foucault (2010a) el discurso nacionalista como aquel que sienta sus bases en el conocimiento de la historia y en otras conformaciones ideológicas (como la novela, y más específicamente la novela histórica).
} 
lectores que, a través de unas mismas lecturas, se han convertido en asociaciones de amigos que congenian?» (Sloterdijk, 2000, pp. 24-25). En función a este planteo, creemos que la Colección... fue un proyecto que buscó crear esa noción de nacionalidad sobre la base de los textos publicados. ${ }^{2}$

Tomando en cuenta lo trabajado en Uruguay, creemos que uno de los libros más esclarecedores fue el de Real de Azúa, Los orígenes de la nacionalidad uruguaya (1990). En esta obra (en donde se seleccionan trabajos inéditos del pensador), cada uno de los treinta y cinco capítulos aborda el problema del nacionalismo. Este libro criticó la postura historiográfica clásica que buscó las raíces nacionales en las poblaciones indígenas que habitaron nuestro actual territorio. Real de Azúa llevó adelante una excelente obra crítica, documentada y detallada, que desarmó conscientemente cada uno de los postulados esgrimidos por el nacionalismo histórico llevado a cabo por los primeros historiadores uruguayos, y sostenido entre otros por Pivel. ${ }^{3}$ Este estudio erudito permitió observar la base de los constructos discursivos sobre los que se sustentó el concepto de "nación" que el Estado uruguayo pretendió difundir entre la ciudadanía.

Por otro lado, contamos también con el trabajo dirigido por Caetano (2000), que investigó las celebraciones del Centenario del Uruguay hacia 1930, y resaltó el carácter cultural como uno de los rasgos fundamentales para reforzar el sentimiento nacional, además de la tarea que cumplió la educación con sus manuales para la escuela primaria. ${ }^{4}$ Sobre la educación como vehículo de construcción de la nacionalidad, debemos resaltar los trabajos que componen la Historia de la educación uruguaya, ${ }^{5}$ con investigaciones sobre la reforma escolar vareliana y sus consecuencias en el país, que nos permiten visibilizar la formación ciudadana relacionada con la creación de nuevos lectores y con la orientación de las primeras lecturas.

Otro de los ámbitos sobre el que necesitamos centrarnos tiene que ver con las colecciones de libros. Inicialmente y sobre el estudio de colecciones editoriales claves en la formación de la identidad nacional, contamos — entre otros — con el análisis de Olivero (1999), que propone estudiar las distintas colecciones (religiosas, literarias, de propaganda y de divulgación científica) de Francia en el siglo XIX, basándose en la creación de sus catálogos — con especial hincapié en la Colección Charpentier-, y prestando atención a la construcción de ciudadanos

\footnotetext{
${ }^{2}$ Además, también resultan pertinentes los trabajos de Sommer (2010) sobre la novela romántica y la conformación nacional en términos culturales.

${ }^{3}$ Deberíamos agregar el trabajo de Ribeiro (1994), donde se hace referencia a varios de los historiadores que trabajaron a fines del siglo XIX y algunos años más adelante, que fueron responsables del discurso histórico nacional.

${ }^{4}$ Sobre este punto son esclarecedores los trabajos de Acree (2013) y Espiga (2015).

${ }^{5}$ Mena Segarra, Palomeque y Delio Machado (2009), y Palomeque (2012).
} 
— «lúcidos y conscientes»- republicanos. Olivero intenta llevar adelante una investigación centrada en la recepción, estudiando la circulación del libro a nivel regional y en el extranjero.

Los estudios sobre las colecciones de libros, en el ámbito regional, no son algo nuevo, ya que existe gran cantidad de trabajos que han sido esclarecedores y permiten un avance teóricometodológico clave para nuestra investigación. Degiovanni (2007 y 2015) aborda la Biblioteca Argentina $^{6}$ y La Cultura Argentina ${ }^{7}$ (ambas, de 1915), dirigidas por Ricardo Rojas y José Ingenieros respectivamente. A partir de la lectura de Degiovanni, podemos repensar nuestros dos objetos de estudio: la Colección... y Pivel. Degiovanni estudia la puja, dentro del campo intelectual argentino en formación, por imponer una colección de clásicos de la literatura y/o del pensamiento nacionales, que colaborasen en la consolidación de la argentinidad, entre el lectorado ampliado por la reciente alfabetización masiva. Esta puja buscaba, luego de los festejos del Centenario de la Revolución de Mayo (1810), establecer una lectura del pasado y de la identidad argentina a través de textos que aprehendieran las principales características simbólicas y materiales de la argentinidad. El "ser argentino" podía moldearse a partir de la selección de ciertos textos historiográficos, periodísticos, científicos, literarios y ensayísticos, en las colecciones.

Por otra parte, además del sentido simbólico, estaba el aspecto material: ambas colecciones también editaron obras que ya habían dejado de imprimirse y que estaban agotadas, o que tenían poca circulación masiva por ser de lujo.

En la colección que dirigía Rojas se pretendía cohesionar los valores de la argentinidad frente a los cambios que provocaba el llamado "aluvión inmigratorio". Esas posibles alteraciones en términos sociales podrían establecer la caída de las lógicas políticas e ideológicas conservadoras, permitiendo el avance de movimientos socialistas y radicales, alentados por los cambios en las leyes electorales. Por lo tanto, la colección dirigida por Rojas se reconocía como necesaria para mantener la cohesión conservadora de los valores de la nacionalidad argentina.

Gracias a los cambios en las políticas lectoras que había emprendido el Estado argentino a fines del siglo XIX, y que habían hecho disminuir el analfabetismo del $78 \%$ en 1869 al $35 \%$ en 1914, además de un marcado aumento de los sectores medios de la población — de un $15 \%$ a un $40 \%$ entre 1870 y 1914 - el libro era el mejor vehículo para lograr los objetivos trazados (Degiovanni, 2007, p. 12).

\footnotetext{
${ }^{6}$ Rojas publicó, durante algo más de una década, 29 libros, con una tirada cercana a los mil ejemplares por título (Degiovanni, 2007, p. 16).

${ }^{7} \mathrm{La}$ colección de Ingenieros, en diez años, publicó 125 volúmenes, con tiradas que iban de entre tres y cinco mil ejemplares (Degiovanni, 2007, p. 16).
} 
Seis meses después de la aparición de la colección de Rojas, Ingenieros hizo lo mismo, dando lugar a una disputa por los usos del pasado y sobre el porvenir de la Argentina, desde la cultura letrada. Esto generó una polémica entre dos tendencias nacionales asumidas por «la Biblioteca Argentina y La Cultura Argentina, [que] constituyeron así instancias mediadoras en la construcción e imposición de un imaginario de amplias proyecciones sociales» (Degiovanni, 2007, p. 13).

Además, cada obra de las dos colecciones poseía el agregado de los prólogos que, como aparatos de reinterpretación de los textos y de redireccionamiento de lecturas, permitían organizar, con una coherencia buscada, cada obra en una lógica totalizante. Al vincular los textos en el interior de una misma colección, se forja un imaginario nacional canónico, dándole una supuesta coherencia a los proyectos editados.

Cada una de las colecciones estudiadas por Degiovanni respondía a definiciones de argentinidad que dependían de las diferentes «posiciones ideológicas, prácticas disciplinantes y bases sociales» (Degiovanni, 2007, p. 14) a las que respondía cada autor, en lucha por la hegemonía del campo intelectual, y por la imposición de un canon nacional cultural.

Además, el estudio de las formas de circulación, de las políticas editoriales y de los vínculos con el Estado - ya que se trata de dos colecciones relacionadas con capitales privados - , se vincula estrechamente con lo postulado en este trabajo de doctorado.

El proyecto de Ingenieros, según Degiovanni, tuvo un impacto popular muy superior al de Rojas, convirtiendo su colección de libros en la serie más exitosa en términos simbólicos y materiales. El enfrentamiento culmina con la muerte de Ingenieros en 1925, y con la imposibilidad de continuar con la colección, por parte de Rojas, por problemas económicos, en 1928, sumándose además el quiebre institucional del primer ciclo democrático que supuso el Golpe de Estado de 1930.

También podemos mencionar el reciente trabajo de Ribadero (2016), sobre las editoriales Indoamérica y Coyoacán dirigida por Jorge Abelardo Ramos, donde se publicaron obras de autores argentinos y latinoamericanos. Ribadero estudia el entramado de relaciones sociales y las distintas formas materiales que permitieron llevar a cabo esos proyectos, haciendo especial hincapié en la correspondencia como fuente historiográfica. A su vez, el autor lleva adelante un perfil biográfico político e intelectual del editor haciendo hincapié en sus comienzos en el trotskismo, donde adquirió varios conceptos que fueron fundamentales en su futuro próximo, a la hora de analizar el ascenso de Perón y el peronismo al poder en Argentina. Por lo tanto, tenemos que destacar el análisis de Ribadero sobre el trabajo editorial de Ramos, que se enfocó en romper la hegemonía del campo cultural liberal argentino de los años cuarenta y cincuenta 
con Indoamérica, y que buscó luego de la Revolución Cubana, a través de Coyocán, sensibilizar al público lector sobre los problemas que aquejaban al continente latinoamericano.

Por su parte, Sorá (2010) estudia la colección Tierra Firme, que se desarrolla en el Fondo de Cultura Económica (FCE) de México, con una impronta netamente americanista. El autor revela cómo, desde dicha serie de libros, se fomenta - en coincidencia con nuestra investigación - la circulación de ideas y la construcción de redes de figuras involucradas en esta colección, pensada como un espacio privilegiado de religación transnacional. Más recientemente, este mismo autor ha completado su trabajo sobre el FCE y agregado información sobre la editorial Siglo XXI (Sorá, 2017). Allí se ha enfocado en su editor Arnaldo Orfila Reynal que, con su doble función de intelectual y editor — como en el caso de Pivel—, le imprimió un sesgo claramente progresista a los catálogos en los que trabajó, dejando entrever la relación entre su postura ideológica y el intento de construcción de un nuevo tipo de lectorado de clases medias.

También hemos tenido en cuenta el aporte de Mailhe (2018) en relación con la «Biblioteca Humanior del americanista moderno», proyecto editorial dirigido por José Imbelloni, apuntando a un lectorado culto universitario - aunque, como se demuestra en el trabajo, supo llegar a un público más amplio-que se busca concientizar sobre la importancia cultural del americanismo. A través de esta colección editorial, Imbelloni apostaba forjar un americanismo científico, basado en la legitimación de la antropología como disciplina propia, poniéndola en posición de privilegio respecto del resto de las Humanidades.

Finalmente, contamos con el trabajo de Antequera (2004) sobre la Biblioteca Ayacucho, que desde 1974 realiza una selección de textos latinoamericanos que van desde la Colonia hasta el siglo XX, buscando la integración cultural del continente. Esta investigación, sumada al testimonio de Rama (1981), permite observar los enfrentamientos entre diversos intelectuales del período, la concepción subyacente a la elaboración de una colección latinoamericana de literatura e ideas, y la relación de su director, Rama, con el Estado venezolano, que financia este proyecto editorial.

El proyecto de Rama se diferencia con respecto al desarrollado por el Estado uruguayo: uno pretende crear una colección de libros para celebrar la diversidad, buscando la unificación latinoamericana a través de sus letras, mientras que el otro necesita eliminar las diferencias internas, unificar criterios y separar a una nación respecto del resto del continente.

Por otro lado, contamos con los esclarecedores trabajos que realizó de Diego (2015), donde repasa las diversas políticas editoriales llevadas a cabo en América Latina durante el siglo XX, señalando la dificultad de aislar el estudio del libro y la edición en Argentina, en un mercado cada día más integrado. Este análisis nos interesa particularmente para el caso 
montevideano. En especial, la integración regional e internacional del mercado permite encontrar puntos de conexión, ya que en Uruguay son absolutamente escasas las investigaciones sobre el período y la temática. La dificultad de aislar los estudios tiene que ver con la confección de los cánones nacionales, y la casi inexistencia de un canon latinoamericano, como bien postuló Zanetti (1998). Dejando fuera tres excepciones - las de Rama, Cosío Villegas y Henríquez Ureña - De Diego tuvo que aceptar por momentos el corte del objeto de estudio en función de lo argentino, pero sin desestimar las conexiones regionales, y muchas veces con estudios de casos iberoamericanos, con especial foco en México y España.

Uno de los planteos que desarrolla el investigador se adentra en el intento de dar respuesta a la pregunta: «¿hasta qué punto la presencia de un editor marca la política editorial de una empresa, o hasta qué punto es la empresa la que marca las decisiones editoriales de ese editor?» (De Diego, 2015, p. 35). En nuestro caso, es válida no solo la pregunta sino también la doble respuesta, ya que Pivel, en su función de editor y de Ministro, siguió su propia política editorial gracias a los dineros del Estado. Sin embargo, cuando simplemente fue editor y perdió su papel al frente del Ministerio, tuvo que editar aquello que resolvían los integrantes de la clase política.

Finalmente, consideramos también el trabajo de Subercaseaux (2000) sobre la importancia de la circulación del libro en Chile, y su relación con el Cono Sur, atendiendo a la historia de la sociedad y la cultura en relación a la historia de la edición. El enfoque se basa en que no se puede estudiar el libro sin observar la sociedad que lo crea, ni estudiar una sociedad sin prestar atención a las ideas y los libros que circulan por ella (Subercaseaux, 2010, p. 8).

Con respecto al contexto editorial del período aquí estudiado, en el caso particular de Uruguay, Torres Torres (2012) reconstruye el ambiente editorial de los años cincuenta y sesenta. Este trabajo repasa los inicios y el posterior auge de las primeras empresas editoriales, tales como Alfa y Asir, demostrando su influencia cultural en el medio uruguayo, como protagonistas del boom de las letras latinoamericanas durante los años sesenta.

Si bien existe otro trabajo contemporáneo al hecho por la investigadora (Fernández y Villa, 2012), el de Torres Torres apuesta a las múltiples aristas reseñadas por los postulados que la historiografía del libro y la edición han propuesto en los últimos años. Además, se centra en el siglo XX en Uruguay, y no en el XIX, como en el caso de Fernández y Villa. El estudio de Torres Torres pone de manifiesto la importancia que tienen este tipo de investigaciones, ya que desentraña la particular relación de las empresas editoriales con el empuje de las publicaciones desarrolladas por los integrantes de la llamada Generación crítica, doblemente protagonistas como autores y editores de sus propios libros y revistas.

Además, su estudio no se agota en sus editoriales y sus catálogos, sino que también le da especial importancia al contexto sociocultural del Uruguay, y a la figura del editor, destacándose 
especialmente el estudio sobre Benito Milla. Tanto los sellos editoriales de Milla como sus colecciones de libros pretendían establecerse en el campo literario con propuestas diferenciadas respecto de otros cánones postulados por colecciones privadas y por parte del Estado. La Colección..., durante el período posterior al trabajado por esta investigación, ${ }^{8}$ editó a muchos de los autores impresos en Alfa y Asir. Por tanto, los escritores propuestos por dichas editoriales, sobre todo desde la Enciclopedia Uruguaya y el Capitulo Oriental, hicieron mella en el canon oficial. ${ }^{9}$

Específicamente sobre la Colección... dirigida por Pivel, contamos con algunos trabajos breves que abordan lateralmente el tema como los de Ribeiro (1994), Zubillaga (2002) y Sansón (2006). En general, analizan este proyecto editorial a partir de la figura de su director, como parte de su obra intelectual, destacando la importancia del fomento de la lectura lograda por la serie de libros.

También nuestra Tesis de maestría (Gutiérrez, 2013) realizó un primer estudio formal de la Colección..., caracterizando algunas de sus intervenciones, desde que comenzó a editarse hasta 1967, cuando decayó el número de publicaciones. En dicha investigación se consideraron las políticas estatales que orientaron la edición de determinados autores y no de otros, qué textos eran seleccionados, y se indagó inicialmente en torno a las razones de dicha selección.

Con relación a la figura de Pivel, Vidaurreta (2001) reconstruyó su vida personal y académica, reflexionando sobre su trayectoria en los diversos cargos públicos. En general, tal como puede entreverse en su tarea intelectual a la luz del trabajo de Vidaurreta, Pivel usaba palabras de otros para hacerse halagos autocomplacientes, construyendo sobre sí mismo, por ejemplo, la imagen de un funcionario e investigador full time.

Al mismo tiempo, Zubillaga (2002) y Sansón (2006) han indagado en torno a su actividad intelectual, orientada a la historiografía y al desempeño de cargos como agente cultural ligado a funciones públicas. Además, recientemente Espeche (2016) analizó el discurso historiográfico de Pivel, en función de cómo se fue «blanqueando» la Historia, gracias a sus esfuerzos intelectuales a través de la tradición selectiva que construyó. Recordemos que durante la primera mitad del siglo XX la Historia oficial del Uruguay era una versión tejida desde el Partido Colorado y sobre todo sostenida por los historiadores Francisco Bauzá y Eduardo Acevedo. Durante la segunda mitad del siglo XX, Pivel se encargó de amalgamar a la versión colorada una visión revisionista blanca hija de su militancia en el Partido Nacional y de sus contactos con el líder político Luis Alberto de Herrera. Una vez tejida una supuesta Historia

\footnotetext{
${ }^{8}$ Desde los años 2000, se han editado muchos de los autores de la Generación crítica: Carlos Martínez Moreno, Amanda Berenguer, Juan Carlos Onetti y María Inés Silva Vila, entre otros.

${ }^{9}$ Ver Capítulo 6.
} 
nacional oficial y neutral, la tarea historiográfica de Pivel se encaminó a reforzarla durante los años posteriores.

Para definir y problematizar el concepto de "canon", haremos hincapié en una serie de autores que nos han ayudado a reflexionar sobre su construcción (Bloom, 2012; Bourdieu, 1999; Even-Zohar, 1990; Harris, 1998; Kermode, 1998; Pozuelo Yvancos, 1998; Sullá, 1998). Inicialmente, contaremos con Bloom (2012), aunque con recaudos — atendiendo a su posición cerrada, conservadora de la tradición literaria occidental—, y con Bourdieu (1999) y Even-Zohar (1990), apelando a una definición del "canon” como espacio en constante disputa. Algunos autores problematizan desde otras miradas la generación del canon; tal es el caso de Robinson (1998) desde el feminismo, y de Gates (1998) desde la tradición afroamericana, o Moretti (2015), que lo define como una forma de salvar obras del «basurero de la literatura». También repensamos esta definición del canon en diálogo con el concepto de «hegemonía discursiva» en la tesis de Angenot (2010).

En relación con América Latina, Zanetti (1998) pone en consideración la problemática del canon latinoamericano en formación, frente a los ya constituidos y estudiados cánones nacionales. Por otro lado, Cella (1998) remarca la importancia del canon como producto social que, a su vez, es criterio de fijación de reglas y límites del arte. Jitrik (1998), por su parte, hace hincapié en lo marginal, aquello que queda apartado del canon al que considera con un carácter cambiante y múltiple.

También deben considerarse los proyectos de construcción de un canon literario nacional, emprendidos por la crítica literaria, y elaborados con posterioridad a la etapa que es aquí nuestro objeto de estudio. En este sentido, para reconstruir parte de la crítica literaria uruguaya contemporánea a la Colección..., tendremos en cuenta tanto las investigaciones sobre el semanario Marcha (1939-1974) en su sección literaria, y sobre el Capítulo Oriental (19681969) y la Enciclopedia Uruguaya (1968-1970), como la obra crítica de Rodríguez Monegal (1966) y de Rama (1972), claves para aprehender otros modelos canónicos de la literatura nacional. Contamos con trabajos como los de Real de Azúa (1973 y 1984), Aínsa (2002) y Cosse (2008), para pensar una periodización de las diversas generaciones intelectuales nacionales. En particular, Rocca (2006) aborda los recorridos intelectuales de dos críticos fundamentales del período a estudiar — Rodríguez Monegal y Rama, ambos ligados a la serie de libros aquí analizada-, quienes mientras se edita la Colección..., colaboran prologando algunos tomos en ella, al tiempo que producen interpretaciones de la literatura a priori disidentes con respecto a la canonización efectuada por este proyecto editorial. El trabajo de 
este investigador permite observar la relación de ambos críticos con las páginas literarias del semanario Marcha, y la influencia de éste en el campo intelectual uruguayo.

También Rocca (2009) lleva adelante un detallado análisis crítico de algunas de las principales publicaciones periódicas en el Uruguay del período, señalando la dificultad de realizar un estudio separado del ámbito argentino, debido al constante intercambio con la otra orilla — plagada de «encuentros y desarmonías» entre los de «allá» y los de «aquí», según palabras del autor - y comprobando además la preocupación — común entre los intelectualespor fomentar la publicación de los propios escritores uruguayos.

Específicamente sobre el semanario Marcha, contamos con las investigaciones de diversos autores, tales como Alfaro (1984), Rocca (1992), Peirano Basso (2001) y Espeche (2010), entre otros. Estos trabajos permiten comprender la trascendencia de dicha publicación en el campo intelectual uruguayo, como ámbito privilegiado de discusión y enfrentamiento político, estético y cultural en general, entre diversos protagonistas del período, tales como Rama, Rodríguez Monegal, Pivel y Real de Azúa.

Del estado de la cuestión aquí esbozado, se desprende que solo existen trabajos centrados en la publicación de obras de autores uruguayos, durante los años cincuenta y sesenta, que revisan algunos de los intentos por conformar un canon literario, pero solo por parte de la crítica. Además del trabajo ya citado de Torres Torres (2012) sobre Milla y Rama, no se han constatado investigaciones que hayan indagado en torno a la figura de los editores, ${ }^{10} \mathrm{y}$ menos aun al modo en que la Colección... dirigida por Pivel buscó formar un canon literario nacional, atendiendo a la polémica —implícita o explícita — con respecto a otras formas de pensar, en la época, la formación de un canon. Tampoco contamos con un estudio centrado en la figura de Pivel como intelectual formador del nacionalismo uruguayo, sobre todo a partir de su papel como director de dicha serie de libros, en la que se entrecruzan los críticos, los editores y otros intelectuales.

Esta tesis doctoral busca avanzar en algunos tópicos —apenas relevados pero no profundizados en la tesis de maestría defendida en 2013-, especialmente con respecto a la disputa discursiva por la conformación de un canon literario nacional, atendiendo además al papel de este proyecto editorial en la consolidación de la figura de Pivel en el campo intelectual nacional.

\footnotetext{
${ }^{10}$ Están comenzando a desarrollarse algunos estudios sobre editores, gracias al Grupo (Inter) disciplinario de estudios sobre el campo historiográfico-editorial (IPA, CFE) que coordino desde fines de 2018. Dentro de este grupo, se ha reparado en las figuras de Antonio Barreiro y Ramos, Francisco Vázquez Cores, Claudio García y Orsini Bertani.
} 


\section{Los aportes desde la historia del libro y la edición}

Con relación al estudio de la circulación de lo escrito dentro del «círculo de comunicación» (Darnton, 2010), pretendo basarme en algunos lineamientos de historiadores contemporáneos que intentaron desarrollar lo que denominamos "Historia del libro y de la edición" (Febvre y Martin, 2005; Escarpit, 1968; Cavallo y Chartier, 1998; Chartier, 2005; Finkelstein y McCleery, 2014; Barbier, 2015; Dujovne, 2015 y De Diego, 2019), dentro de la "Historia intelectual".

El inicio de los estudios sobre el libro y su proceso de producción estuvo dado por La aparición del libro (1958/2005) de Febvre y Martin. El libro aborda el proceso de producción — la creación de los tipos móviles, la imprenta y la composición, entre otras- y las materias primas necesarias para llevarlo a cabo, con un capítulo inicial específico sobre el papel y los centros papeleros. Además, también se centra en su circulación, tratando el libro como mercancía dentro del mercado. Este trabajo, renovador en su momento, dio inicio a una serie de estudios que se diversificaron y profundizaron con el tiempo, a la vez que permitió la formulación de nuevas preguntas sobre cada etapa del proceso, junto con la incorporación de innovaciones metodológicas importantes.

Por otro lado Chartier (2005), siguiendo los lineamientos de Michel de Certeau, propone asociar la crítica textual, la Historia del libro (estudiando el objeto impreso en cuestión), y la llamada "Sociología de las prácticas de lectura", tendiendo así a establecer una relación entre las modalidades de apropiación de los textos y el proceso de su interpretación.

Dujovne (2015) aporta una investigación que parte de los postulados de la llamada “Sociología de la edición”. Su trabajo sobre el libro judío supone un excelente ejemplo de cómo integrar el estudio de una colección o serie de volúmenes y su relación con el mercado, los intelectuales, editores, traductores, partidos políticos e instituciones judías extranjeras y nacionales, entre otros actores.

Para problematizar algunos postulados metodológicos sobre el vocabulario a utilizar y los intercambios académicos de la Historia de la edición y del libro, creemos pertinente tener en cuenta lo planteado por De Diego (2019). El autor escoge varios temas sobre los que se debate en al ámbito académico actual: las relaciones entre los editores y las políticas editoriales; las diferencias entre el estudio del libro, la edición y la lectura; las investigaciones centradas en lo nacional frente a las que pretenden tener un alcance internacional; las conflictivas relaciones entre lo disciplinario y lo interdisciplinario, y los alcances de los estudios cuantitativos y cualitativos. En cada uno de ellos, las reflexiones llevadas a cabo por el investigador permiten precisar la terminología utilizada a lo largo de esta tesis. 


\title{
CAPÍTULO 2
}

\section{LAS PRIMERAS EMPRESAS EDITORIALES Y EL DESARROLLO DEL MERCADO EDITORIAL}

Editar libros en una plaza tan pequeña como la montevideana, a fines del siglo XIX, era una tarea quijotesca. ${ }^{11}$ Con menos de un millón de habitantes y con una tasa de alfabetización debajo del $70 \%$, Uruguay era un ámbito poco atractivo para producir libros. ${ }^{12}$

A principios del siglo XX, y gracias al primer censo que se realizó en 1908, se produjeron algunos datos sobre el círculo editorial nacional. En consecuencia,

\begin{abstract}
...es posible identificar la existencia en la capital de siete imprentas, veinticuatro tipografías, dos talleres gráficos, ocho talleres de encuadernación y dieciséis establecimientos de librerías, además de otros veintiocho que comparten el comercio de libros con la venta de papelería y anexos, y otra línea que destaca «Papelerías y librerías con talleres gráficos», totalizando en este caso 17. Una docena de personas trabajan en las librerías, mientras que en librerías y papelerías con talleres gráficos se emplea a 261, siendo 691 los tipógrafos (entre ellos, dos mujeres). Este último guarismo es altísimo, si se toma en cuenta que, por ejemplo, los jardineros registrados por el documento censal son 353 y los profesores de todas las asignaturas, tanto en Educación media como superior, llegan apenas a 293. Es decir, los profesores son el $40 \%$ de la cantidad de tipógrafos de la capital uruguaya. Solo para tomar un término de comparación, en 1889 los tipógrafos eran 602, es decir, un $15 \%$ menos que en 1908. El minucioso registro oficial no incluye en su nomenclatura la palabra «editorial» ni discrimina —no podía hacerlo- la producción especializada de libros de la de otros impresos (Rocca, 2012).
\end{abstract}

El comienzo del mercado editorial estuvo relacionado con la inmigración, especialmente con la gallega. Mayoritariamente, los futuros editores comenzaron sus días como libreros y se independizaron posteriormente gracias al ahorro de un capital inicial y a sus relaciones con los autores y compradores.

El pionero en el negocio fue Antonio Barreiro y Ramos, quien comenzó publicando la mayoría de los autores de historia y literatura de la época. Sin embargo, como veremos, prontamente surgieron otros competidores.

\footnotetext{
${ }^{11}$ Según los censos, en 1860 había en Montevideo 57.913 habitantes, mientras que en 1908, 309.231 (Nahum, 2007).

${ }^{12}$ Según el censo de 1908, en Uruguay había 1.054.190 habitantes, y una tasa de analfabetismo del 35,44\% (Nahum, 2007).
} 
Barreiro y Ramos era oriundo de un pueblo español llamado Laracha, a $25 \mathrm{~km}$ de La Coruña. En 1867, cuando tenía 16 años, llegó a Montevideo y comenzó a trabajar en la librería más importante de la capital, llamada Real y Prado. Según se contó en un folleto consagratorio de su figura, ${ }^{13}$ desde los primeros años comenzó a estudiar por su cuenta contabilidad y francés, además de leer todo tipo de libros que conseguía gracias a su empleo de librero. Según contaba su empleado y biógrafo Benjamín Fernández y Medina, «...los días y horas que otros dedican á fiestas y diversiones, él los consagraba al estudio y á la conversación con hombres superiores á él en edad, y que, como Carrera, eran tan útiles como los mejores libros» (1918, p. 4).

Barreiro y Ramos tuvo contacto, desde su adolescencia, con editores y libreros españoles que le permitieron entender y replicar ciertas medidas innovadoras para su nuevo negocio. En 1871 fundó la Librería Nacional, dedicada a la venta de libros de texto para los estudiantes de enseñanza primaria y media. Según Fernández y Medina, Barreiro pensaba que

\begin{abstract}
...la cultura intelectual se debía hacer cada día más intensa, que el afán de ilustrarse se extendía á todas las clases — que la escuela y el espíritu democrático auxiliaban una evolución igualitaria que hacía confundir á los nativos con los extranjeros-, á los trabajadores de la última hora con los hijos de los trabajadores de la primera hora, realizándose en cierta forma la parábola de la retribución que no mira cuándo empezó cada uno sino lo que ha hecho y puede hacer (Fernández y Medina, 1918, p. 5).
\end{abstract}

En 1881 Barreiro fue a Europa a estudiar personalmente las impresoras, librerías y casas editoras. A raíz de la crisis económica de 1890, la imprenta tuvo que parar sus actividades. Una vez superada la recesión, hacia 1895 se retomó la producción, y uno de los libros más importantes de la historiografía nacional, la Historia de la dominación española en el Uruguay de Francisco Bauzá, inauguró el nuevo ciclo de edición.

Como consecuencia de los múltiples problemas que encontraba en el proceso editorial, y como forma de mejorar sus ganancias, Barreiro comenzó a instalar los primeros talleres gráficos del país, que contaban con máquinas para la impresión y encuadernación, y con litografía. Es importante reseñar que fue el primero que pudo completar el ciclo editorial, al editar, imprimir y comercializar sus propios libros. ${ }^{14}$

En 1903 editó una serie de libros en octavo menor sobre historia uruguaya, conocida como la Biblioteca Popular de Historia Nacional, en cuya justificación se leía que

...sabido es de todos que entre nosotros las obras de carácter histórico no llegan hasta las clases populares, ni menos a manos de la infancia, debido al

\footnotetext{
${ }^{13}$ El que escribió el folleto fue Benjamín Fernández y Medina, quien trabajó con Barreiro durante sus últimos 25 años. Allí se intenta hacer ver al fundador de la librería como un self-made man.

${ }^{14} \mathrm{El}$ catálogo llegó a contar con más de un centenar de obras. Ver Apéndice.
} 
hecho de ser aquéllas excesivamente costosas, demasiado extensas, al par que su estudio requiere cierra preparación especial que, por desgracia, ni todo el pueblo posee, ni se suministra a la infancia [...]; lo que nos induce a creer que todo empeño hecho en el sentido de difundir la historia patria entre has clases sociales de posición humilde, tendrá buena acogida, por más que esta, por grande que sea, no compense lo bastante la magnitud de la empresa que abordamos (cf. en Zubillaga, 1999, p. 140).

Entre 1902 y 1912 Barreiro volvió a viajar a Europa para estudiar los progresos en las artes gráficas y comprar elementos para mejorar las condiciones del taller, así como también para responder a las necesidades que se tenía en el país.

Entre 1890 y 1916 — año de la muerte de Barreiro y Ramos_, funcionó la llamada "Tertulia de Barreiro", donde políticos, poetas, ensayistas y otras personas de la cultura debatían temas de actualidad. También era un lugar de encuentros, además de un espacio fundamental para tejer redes intelectuales en el pequeño campo intelectual del Uruguay; muchos de sus miembros pasaron a integrar los catálogos de esta primera editorial uruguaya.

Otro editor gallego que llegó, pasada la segunda mitad del siglo XIX, fue Francisco Vázquez Cores. Gracias a la amistad que desarrolló con el impulsor de la reforma escolar, José Pedro Varela, a su profesión de maestro y la pésima calidad de los libros escolares de la época pensó en manuales para el uso escolar que abarcaran gran cantidad de disciplinas como Historia, Geografía, Idioma español o Zoología, entre otras.

En 1883, gracias a un crédito otorgado por Barreiro y Ramos, Vázquez Cores pudo abrir la Librería Universal y comercializar sus propios libros. Finalmente, entre 1886 y 1913, se imprimieron miles de manuales que sirvieron a los escolares uruguayos. También tuvieron éxito los famosos Cuadernos de escritura Vázquez Cores, que marcaban las líneas para una buena caligrafía e incluían dibujos sobre las correctas posturas a la hora de escribir.

Junto a Dornaleche y Reyes ${ }^{15}$, Vázquez Cores editó al poeta Francisco Acuña de Figueroa (Zubillaga, 1999, p. 141). Sin embargo, sus negocios terminaron mal, ya que se fundió, y en 1914 terminó muriendo en la extrema pobreza en un hospital de beneficencia.

Debemos agregar a esta lista a José María Serrano, dueño de la Librería Cervantes, quien editaba pero no imprimía sus libros, ya que nunca contó con imprenta propia y, a raíz de dicho problema, las tenía que contratar externamente.

El autor más importante que tuvo para editar fue José Enrique Rodó, quien entre 1909 y 1913 publicó Motivos de Proteo y el Mirador de Próspero (en primeras ediciones), y Ariel en una reimpresión. Además de dedicarse a cuidar las ediciones del ensayista, lo asesoró internacionalmente, cumpliendo un rol de agente hacia Europa y el resto de América Latina.

\footnotetext{
${ }^{15}$ Esta editorial estuvo mayoritariamente enfocada en libros de derecho, y funcionó entre 1881 y 1926.
} 
Gracias a sus vínculos con Rodó, pudo editar a integrantes de su círculo, como Hugo Barbagelata, Juan Antonio Zubillaga, Asdrúbal Delgado, Baltasar Brum, Ariosto González y Orestes Araújo (Zubillaga, 1999, p. 142).

El único de los editores que era de origen italiano fue Orsini Bertani, quien tuvo fuerte presencia dentro del mundo literario, manteniendo vínculos con numerosos integrantes de la Generación del Novecientos.

Por su ideología anarquista, Orsini tuvo que huir de Italia en 1889, llegando primero a la Argentina. Hacia 1900 fue perseguido políticamente, lo que implicó su desembarco en Montevideo, donde fundó la Librería Moderna, y donde terminó por adherirse al anarcobatllismo $^{16}$. En 1904 creó su editorial — con la que publicó 135 títulos — con dineros de su padre, un reconocido importador de productos italianos afincado en Buenos Aires (Rocca, 2012).

Entre 1927 y 1931, publicó la revista literaria La Pluma (bimensual), que tuvo entre sus colaboradores a varios literatos y pensadores uruguayos de la época, importantes y consagrados, como Juana de Ibarbourou, Juan José Morosoli, Roberto Ibáñez, Emilio Oribe, Francisco Espínola, Luisa Luisi y Alberto Zum Felde, quien era su director (Torres Torres, 2012, p. 45).

Como editor, también publicó a Julio Herrera y Reissig, Emilio Frugoni, Líber Falco, Delmira Agustini y Florencio Sánchez, entre otros. Según Pablo Rocca, Bertani fue el «primer editor puro en Montevideo, es decir de quien sin desprenderse de otras actividades (librero, impresor), apostó por la formación de un catálogo de libros independiente de esas otras vías» (2012, p. 2).

Como decía el ex director de La Pluma,

...su librería — lo de Orsini, decíase — instalada en el punto más estratégico de la calle Sarandí, fue centro de tertulia literaria en aquellos años febriles en que la sociología revolucionaria y la lírica decadente compartían los entusiasmos de la juventud. Todas las tardes - a la hora del paseo crepuscular por esa aorta urbana - la pequeña librería congregaba a la élite de nuestros escritores. Fue este Orsini — tipo inteligente y dinámico— quien, después de su famosa venta de la colección Sempere a quince centésimos el tomo siembra pródiga de «cultura» en el ambiente popular- estableció una imprenta y se puso a editar generosamente a todos los escritores nuevos (Zum Felde, 1930, pp. 67-68).

Las inexistentes políticas estatales de apoyo a empresas culturales, el pequeño mercado y la apuesta en favor de libros con poco éxito comercial — como los de poesía- hicieron que la

\footnotetext{
${ }^{16}$ Así se llamó una corriente del anarquismo uruguayo que apoyó, durante la segunda presidencia de Battle y Ordóñez, las medidas tomadas durante su período de gobierno.
} 
actividad editora de Bertani comenzara a mermar a fines de la década del diez, lo que llevó a su inexorable desaparición en 1917.

Contemporáneo de Bertani fue Claudio García — también de origen gallego, como los anteriores reseñados_- Llegado a Montevideo en 1894, García comenzó su negocio comprando y vendiendo libros usados. Luego de un breve paso por Buenos Aires, donde estuvo en contacto con los círculos intelectuales porteños en los que se encontraba José Ingenieros, decidió fundar su editorial en 1914 bajo el nombre de La bolsa de los libros (Zubillaga, 1999).

Gracias a ediciones baratas,

...muchos de los títulos publicados por «La Bolsa de los Libros», la libreríaeditorial de Claudio García, surgieron por la demanda de los desasistidos estudiantes y profesores del ámbito secundario para cumplir con su tarea didáctica. Esto explica la presencia de pequeñas antologías poéticas de José Asunción Silva, Rubén Darío, Olavo Bilac, Baudelaire y tantos otros integrados a las exigencias oficiales (Rocca, 2012, p. 7).

García puso en circulación dos colecciones: Cultura, que contó con ochenta volúmenes de escritores internacionales dispuestos a cumplir con los programas de estudios secundarios y preparatorios, y Rodó, de autores nacionales, con 150 títulos que superaron el medio millón de ejemplares (Speroni, 1989, p. 10). Estas series de libros, que alcanzaron amplia difusión gracias a los importantes tirajes y bajo costo - entre $\$ 0,30$ y $\$ 1$ y con descuentos para estudiantes y profesionales-, fueron posibles gracias al poco interés que tuvo García en hacerse cargo de los derechos de autor y del pago de regalías ${ }^{17}$ (Speroni, 1989).

El editor conseguía recursos gracias a su actividad como vendedor de libros usados, de la que obtenía el dinero que luego invertía en la imprenta. Durante cuarenta años editó todo lo que llegaba a sus manos. García empezó con folletos que vendía a un costo de entre cinco y diez centésimos, luego se encargó de imprimir obras literarias y de jurisprudencia, que hacía sin importar su éxito editorial o a sabiendas del rotundo fracaso de muchas de sus publicaciones (García Berisso, 1956).

En los años cuarenta La bolsa de los libros editó la Biblioteca Rodó, que pretendía representar lo mejor de las letras uruguayas. ${ }^{18}$ La corta aventura de esta serie de libros dará inicio a un largo impasse editorial.

\footnotetext{
${ }^{17}$ Tuvo un enfrentamiento con Leopoldo Lugones, a raíz de su obra Las montañas de oro, que García editó sin consentimiento ni autorización. Este hecho valió la llegada del escritor a Montevideo, pidiendo una ley de propiedad intelectual, sin que revistiera consecuencia alguna para García, quien mantuvo sus procedimientos (Speroni, 1989).

${ }^{18}$ Ver capítulo 6.
} 


\section{El impasse de los libros y el boom de las revistas}

Hacia fines de los años veinte y principios de los cincuenta, el grueso de las publicaciones fue hecho por las revistas literarias y la prensa periódica. Si bien existieron algunas pequeñas editoriales artesanales con muy baja tirada y circulación, el campo cultural se vio invadido por las revistas, que se multiplicaron y fueron el principal órgano de expresión de los escritores por aquellos años.

Como expresaba Rama,

... la muchedumbre de revistas, semanarios y colecciones populares de literatura (la novela levanta su vuelo) tendrán vidas intensas y por lo general efímeras, y en los 20 se presencia un «boom» que púdicamente se ahorró esta denominación de mercadeo. Pareció posible que los intelectuales actuaran directamente sobre el público (y este reactuara sobre ellos, imponiéndoles incluso una escritura y especiales formas) sin que esa comunicación fuera orientada y condicionada desde el poder, sean quienes fueran los que lo ocupaban (Rama, 1998, p. 169).

Este primer boom del que hablaba Rama es observable en la gran cantidad de títulos que comenzaron a comercializarse durante los años reseñados, entre los que encontramos a Los Nuevos (1920-1921), Semanal Film (1920), Cinema y Teatros (1920-1921), Reseña (19221927), Cine Revista (1922-1923), Analectas (1923-1924), Alfar (1923-1955), Boletín de Teseo (1923-1925), Actualidades (1924), La Cruz del Sur (1924-1931), Páginas de Arte (1926-1927), La Pluma (1927-1930), Cartel (1929-1931), La Gaceta de Montevideo (1930), La Escoba (1934), Hiperión (1935-1950), Bosquejos (1935-1936), Aportación (1935), Caminos (1935), Ensayos (1936-1939), Cine/Radio/Actualidad (1936), Círculo y Cuadrado, Revista de la Asociación de Arte Constructivo (1936-1943), AIAPE (1936-1944), El David (1937-1939), Revista Nacional de Literatura (1938-1968), Las Compañias (1938-1956), Mentor (1938-1945) y Ansina (1939-1942). ${ }^{19}$

Esa multiplicación de las revistas, y la caída del negocio librero, dieron lugar a una de las generaciones literarias menos recordadas de las letras nacionales y de las más cuestionadas por parte de los intelectuales de las décadas posteriores. ${ }^{20}$ Hablamos de la Generación de 1930, también llamada del Centenario ${ }^{21}$. Los integrantes de la Generación crítica la definían como un grupo de escritores que vivió a costa de favores políticos, publicando para una pequeña camarilla autocomplaciente de seguidores, haciendo circular sus escasas producciones literarias

\footnotetext{
${ }^{19}$ Ver: Anáforas, en: http://anaforas.fic.edu.uy/jspui/.

${ }^{20}$ Durante los años treinta, Uruguay vivió el ocaso del batllismo, junto a las consecuencias de la crisis de 1929. A nivel político, gobernaba el primer presidente y luego dictador Gabriel Terra.

${ }^{21}$ En 1930 se conmemoraba el centenario de la primera y derogada — hacía tan solo trece años-Constitución.
} 
para un reducido grupo o incluso para instituciones estatales que se apropiaban de los pocos ejemplares salidos en ediciones únicas. Entre sus nombres más importantes podemos citar a Francisco Espínola, Susana Soca, Juan José Morosoli, Justino Zavala Muniz o Líber Falco, entre otros.

Las pocas publicaciones en formato libro que se podían realizar, por lo pequeño del mercado y lo costoso de cada ejemplar, terminaban siendo adquiridas por el Estado uruguayo. Según se pudo constatar, la manera habitual que utilizaba la administración estatal era la compra directa de entre doscientos y trescientos ejemplares para repartir entre instituciones públicas. ${ }^{22}$ Asegurarse dicha compra permitía pagar los gastos de la obra, que eran financiados por sus autores.

Si bien en Uruguay los problemas editoriales estaban extendidos en el tiempo, en la vecina orilla la situación era diferente. Como consecuencia de la Guerra Civil Española (1936-1939), gran cantidad de editores y sus respectivas casas editoriales emigraron hacia el continente americano; muchos figuras del exilio español llegaron a Buenos Aires. Según de Diego (2014), entre los años 1938 y 1955 Argentina se encontraba en la edad de oro de la industria editorial. A modo de ejemplo citaremos tres casos.

En 1937 Manuel Olarra, Gonzalo Losada y Julián Urgoiti fundaron la editorial Espasa Calpe. De ese núcleo fundacional saldrán los tres sellos editoriales más importantes de la época. En 1938 sacaron la conocida Colección Austral. Sus números de producción fueron realmente impresionantes: en casi treinta años, había editado mil quinientas obras con entre diez y veinte títulos nuevos por año — con tiradas de primera edición que llegaban a los doce mil ejemplares, y varias reimpresiones de seis mil-. De la producción total, cerca del $30 \%$ se exportaba a otros mercados regionales (De Diego 2014, pp. 97-98).

En 1938 Losada se desvinculó de la editorial, y en agosto abrió la suya propia para competir con Austral ${ }^{23}$. También sacó una colección, llamada Contemporánea, que más adelante se transformó en Clásica y Contemporánea, con cuatrocientos títulos en su haber.

Posteriormente, en diciembre de 1938, Urgoiti fundó la editorial Sudamericana, que durante los años cuarenta no publicó casi autores argentinos, pero que hacia los sesenta, en plena ebullición del mercado editorial, configuró el canon regional con Julio Cortázar,

\footnotetext{
${ }^{22}$ Algunos de los autores que utilizaron este método durante los años treinta y cuarenta fueron Daniel Vidart en Tomás Berreta, Luis Alberto Caputi en El vitral de los cuervos, César Aguirrezabala en Sobre las viñas muertas, Carlos A. Oliveri en Aportes a la historia de la Marina de guerra nacional, Lauro Ayestarán en Música en el Uruguay, José Antuña en Un panorama del espíritu, Ida Vitale en Poesía dada, Antonio Larreta en Oficio de Tinieblas, Juan José Morosoli en Vivientes y, la Revista Asir que solicitó la compra de la novela Lloverá siempre de Carlos Denis Molina (AGNU, Ministerio de Instrucción Pública).

${ }^{23}$ Entre los fundadores también se encontraban Guillermo de Torre, Atilio Rossi, Amado Alonso, Pedro Hernríquez Ureña y Francisco Romero, a los que se agregaron posteriormente los hermanos Luis y Felipe Jiménez de Asúa, Teodoro Becú y Lorenzo Luzuriaga (De Diego, 2014, p. 99).
} 
Leopoldo Marechal y Ernesto Sábato, entre otros — junto a Borges, quien editó en Emecé, fundada en 1939 por Mariano Medina y Álvaro Casas- (De Diego, 2014).

Esas tres editoriales ampliaron y diversificaron sus mercados durante las décadas posteriores, hasta que España pasó nuevamente a producir sus libros, y el enfoque de su producción pasó al mercado interno y al sudamericano, para dar lugar al famoso boom de los años sesenta.

Claramente, estas editoriales tuvieron éxito sosteniéndose en una coyuntura económica favorable para la Argentina y la región —el desarrollo del modelo de industrialización por sustitución de importaciones y la Segunda Guerra Mundial—, además de la ampliación sostenida del público lector. Para poner en números esta Edad de oro, podemos decir que en Argentina, durante el período $1900-1935$, se registraron 2.350 obras, mientras que en los tres años siguientes, 5.536. En números de ejemplares vendidos, entre 1936 y 1940, fue de 34 millones, y entre 1951 y 1955, de 169 millones. El promedio de tiraje, entre 1938 y 1955, fue de siete mil ejemplares, y además cerca del $40 \%$ de los libros se exportaban (De Diego, 2014, pp. 112-113).

En los catálogos de la época, la mayor parte de los libros producidos no eran de autores argentinos, ya que el mercado estaba más centrado en la exportación. Sin embargo, durante los sesenta, la situación cambió drásticamente: la autoría de las obras pasó a centrarse en los argentinos, y las ventas, en el mercado nacional (De Diego, 2014).

\section{Marcha y la Generación crítica}

Al finalizar la década del treinta, apareció una de las publicaciones más importantes del panorama cultural uruguayo: Marcha. El semanario tuvo directa relación con una de las generaciones de mayor importancia en el medio intelectual, la Generación crítica o del 45.,Ese año fue elegido en forma autorreferencial por Emir Rodríguez Monegal24 —en relación con su asunción

\footnotetext{
${ }^{24}$ Emir Rodríguez Monegal (1921-1985) fue una de las figuras críticas más importantes del período. Fue redactor de notas sobre distintas expresiones artísticas en los campos de la literatura, el teatro y el cine. Al frente del semanario Marcha (1944-1959) escribió gran cantidad de notas de carácter literario y puso nombre, como hemos ya mencionado, a la Generación crítica. Carlos Real de Azúa lo definió como un hombre que «fijó lo que habían de ser los gustos y categorías del sector más considerable de la generación», que ejerció la crítica con «la pasión por la lucidez (una palabra que fue bandera de casi todos), el rigor judicativo, la reverencia por los valores de perfección estructural y formal y por la riqueza imaginativa, el desdén por la trivialidad testimonial, el emotivismo, el regionalismo, la inflación expresiva, el desprecio por la literatura protegida, oficial y perfunctoria, la urgencia por una exploración desapasionada de nuestro caudal literario y un inventario de lo salvable de él, la prescindencia de toda consideración 'extraliteraria' y 'extraobra' (de piedad, pragmática, beneficiente, civil). Y todavía el ensanchamiento de idiomas y lecturas y la congregación olímpica de unos dioses mayores: Proust y Henry James, Joyce, Kafka, Gide, Faulkner, Shaw, Mann, Virginia Woolf entre otros universales; y los hispanoamericanos Borges y Neruda y Luis do Rego y Manuel Rojas; y los uruguayos revalorizados o ensalzados: Acevedo Díaz, Quiroga y Rodó, Espínola y Onetti» (Real de Azúa, 1964, pp. 550-551). Rodríguez Monegal diseminó también sus ideas desde Número y El País. Publicó una importante cantidad de libros que recolectaron muchas de sus notas
} 
de la dirección de Marcha-. Según Rodríguez Monegal, allí se nucleó un grupo de intelectuales uruguayos que intentaron desarrollar su actividad creativa en momentos en que el mercado era realmente minúsculo.

Rodríguez Monegal consideraba que uno de los grandes responsables en la gestación del nuevo grupo de escritores fue el semanario Marcha, creado por Carlos Quijano. Su trascendencia en la realidad del Uruguay no se vería marcada por su militancia política - como pretendía Rodríguez Monegal-, sino por su proyecto periodístico. El primer número de Marcha salió en junio de 1939 y en esa difícil tarea fue ayudado por Julio Castro — maestro de profesión y especialista en el acontecer nacional — y por Juan Carlos Onetti — secretario de redacción, «a la orden las 25 horas del día», según se ocupaba de manifestar el propio escritor. También participaron Francisco Espínola como crítico teatral, Lauro Ayestarán en la sección musical, Arturo Despouey en cine, Dionisio Trillo Pays, quien tomó la posta después de Onetti en la página literaria, y Pivel como habitual colaborador en la parte histórica (Rodríguez Monegal, 1966, p. 24). También se ha querido llamar a este grupo de escritores como la Generación de Marcha. Si bien en su momento hubo un extenso debate sobre cómo se debía denominar a dichos intelectuales, el nombre más extendido dentro de la academia fue el de Generación crítica.

Desde el primer momento, los intelectuales que integraron esa generación discutieron cuándo datar su comienzo. Una de las fechas propuestas fue 1939 cuando, como ya dijimos, salió a la venta el primer número de Marcha. También ese año se publicó una de las obras que establecería un cambio radical en la literatura, El pozo de Juan Carlos Onetti, considerado por entonces como el patriarca generacional, quien marcó un nuevo rumbo en muchos aspectos por ejemplo, fue la primera novela uruguaya que tuvo como escenario a la ciudad de Montevideo y donde se trabajó con un personaje principal inscrito en los márgenes de la sociedad-.

La publicación de una de las primeras notas críticas realizadas en Marcha, por parte de Onetti, refuerza su imagen como precursor de esta generación. El título fue «La piedra en el charco» (Onetti, 28 de julio de 1939) y su firmante, a través de un seudónimo, se presentó como Periquito el aguador. Esa sería la primera nota — apenas unas veinte líneas en cada una de las tres columnas que la integraron, bien espaciadas y separadas por asteriscos, junto a algunas

críticas y en algunos casos algunas conferencias como José Enrique Rodó en el Novecientos (1950), Objetividad de Horacio Quiroga (1952), Narradores de esta América (1962), Eduardo Acevedo Díaz (1963) y Literatura Uruguaya del medio siglo (1966). Estuvo presente como prologuista de la Colección en cuatro obras: Nativa, Grito de Gloria y Lanza y Sable de Eduardo Acevedo Díaz, y en una selección de cuentos de Horacio Quiroga. Ver también Alsina Thevenet y Rocca (1994) y Rocca (2006). 
ilustraciones - que daría comienzo a la actividad exclusivamente crítica desde las páginas literarias de Marcha.

La figura del escritor, para el creador de la mítica Santa María, debía dedicarse solo a la escritura propiamente dicha y no intervenir en política. Esta sería una postura enfrentada tiempo después por los adeptos a la imagen del escritor comprometido, impulsada por las ideas militantes de Jean Paul Sartre.

El magisterio de los integrantes de dicha Generación no solo se realizó desde las publicaciones periódicas, las cátedras de letras de la Facultad de Humanidades y Ciencias, y dentro del Instituto de Profesores Artigas (IPA), sino también desde otros ámbitos de sociabilidad como los cafés, en los que tuvieron lugar tertulias, como en el caso de los famosos Polo Bamba, Tupí Nambá, Café Metro, El Ateneo, Libertad, Sorocabana o Sportman, entre otros.

Según describía Rama,

\begin{abstract}
...en aquellas ciudades donde el progreso económico había distendido a la sociedad, acrecentando el número potencial de consumidores, proveyéndolos de recursos suficientes, se presenciaría una sostenida actividad intelectual para proveer a ese público de ideas de objetos culturales, desarrollando mensajes educativos que no solo no pasaban por los órganos del poder sino que se enfrentaban a ellos. Aunque son muchos y de variadas maneras, los que contribuyen a este fin, es en las filas del pensamiento crítico opositor donde se reclutan los primeros contingentes, auspiciando experiencias que resultaron asombrosas por lo desconocidas y que diseñaron el primer camino independiente del poder que transitaron los intelectuales, en el cual persistieron algunos hasta nuestros días (Rama, 1998, p. 163).
\end{abstract}

Rama observaba algo extensible a Latinoamérica, que podía aplicarse a lo sucedido en Montevideo durante los años posteriores al batllismo. Ese grupo de intelectuales que fue ganando autonomía encontraría su tribuna editorial en el semanario de Quijano. Por Marcha pasaron importantes representantes del pensamiento uruguayo. Tan solo con observar la lista de nombres de sus colaboradores, o simplemente con hojear algunas de sus páginas, vemos la importancia de aquellos articulistas y la trascendencia de sus palabras en aquellos años. Hablamos de momentos claves a nivel interno e internacional: recordemos que hacia setiembre de 1939, comenzaba la Segunda Guerra Mundial, que terminó en 1945, fecha que finalmente fue utilizada para designar a este grupo de intelectuales. Posteriormente se observó el inicio del mundo bipolar con la llamada Guerra Fría, que trajo consecuencias en Uruguay, con un posterior escenario de enfrentamiento entre posturas contrapuestas, a lo que se sumó la Revolución Cubana de 1959, que sacudió el continente americano. 
Los integrantes del 45 fueron reconocidos por parte de la historia literaria como una generación crítica debido a su postura frente a la realidad. La crítica fue su valor más enaltecido y reafirmado en cada una de sus posiciones militantes. Esta generación quiso impulsar desde su misión comprometida un triple cambio, ya que "implantó el inconformismo y la modestia y prescindió de todo apoyo oficial; restauró la crítica literaria documentada y rigurosa; renovó el estilo, acercando la literatura a la realidad circundante, poniéndola al alcance de la comunidad para la cual se produce" (Maggi, 1968, p. 34).

Desde la conformación de la Generación crítica, se publicaron gran cantidad de revistas sobre literatura, historia, filosofía y demás aéreas del pensamiento. Entre ellas pueden mencionarse Clinamen — cinco números, 1947-1948—, Escritura — nueve entregas, 19471950_, Asir —39 entre 1948 y 1959—, Marginalia — seis publicaciones, 1948-1949—; Número -31 entregas entre 1949 y 1964 - Entregas de la Licorne —-13 números en su etapa uruguaya, 1953-1961 - y Nexo — cuatro números, 1955-1959—. Por esta razón, también fue propuesto para ellos el apodo de Generación de las revistas.

La postura crítica que proclamaba la nueva generación parecía que lo había abarcado todo, estableciendo un mínimo denominador común, como se encargó de observar Rama:

\begin{abstract}
... la tarea de los poetas, de los revisionistas históricos, de los nacionalistas y ruralistas, de los narradores del presente social, de los editorialistas de Marcha, de la multiplicidad de críticos [de cine, de teatro, de música, de literatura], de los cristianos de una economía humana, de los sucesivos movimientos estudiantiles, de los sectores de extracción marxista, de las ideologías «terceristas», de los hombres que hicieron el nuevo teatro, de los pintores desde el taller Torres García hasta la explosión de individualidades, de las revistas literarias y cada vez más políticas, de las agrupaciones ideológicas del tipo Nuevas Bases, concluimos razonando que todos ellos corresponden a la asunción de una conciencia crítica (Rama, 1969, p. 103).
\end{abstract}

Ese corte transversal que detallaba el autor fue el que convirtió esta nueva posición crítica en uno de los focos que pretendía el cambio político durante los años posteriores. El estrato social de estos integrantes era en su mayoría de las clases medias, que se sentían despechadas contra las promesas incumplidas del batllismo. Carlos Maggi sintetizó el cometido de este grupo de intelectuales diciendo que

...ninguno de ellos se cree escritor ni admite que nadie lo sea, salvo la prueba de una obra valiosa y resistente. La literatura es para ellos un oficio difícil de aprender y por cuyo ejercicio no se puede pedir nada como no sea la posibilidad de ser actuante dentro de la comunidad en la cual se vive. La modestia, la dureza y el inconformismo con los mayores y con los coetáneos [rivales o amigos], el desinterés por el dinero, la fama inmediata o el favor 
oficial de cualquier clase, son los signos éticos, la reacción de los jóvenes que irrumpen en Montevideo hacia el final de la segunda guerra mundial y que en los siguientes veinte años habrían de transformar el clima cultural del país (Maggi, 1968, p. 35).

El escritor uruguayo definía el grupo que él integraba como gente con cierta humildad intelectual que pensaba más allá de su encasillamiento, buscando la autonomía económica y de pensamiento, sin rendir cuentas al Estado y con un objetivo claro: transformar la realidad cultural del Uruguay.

Para Rama, la postura crítica de esta generación se resumía en «el cuestionamiento de las formas establecidas, problematizándolas, separando aisladamente sus partes integrantes, desintegrándolas bajo la óptica analítica - para así, atomizadas, destruirlas» (Rama, 1971, p. 345). En resumidas cuentas, durante las décadas del cuarenta y del cincuenta, los críticos no hicieron más que atacar las ideas constitutivas del imaginario cultural uruguayo, para luego instalarse en los puestos clave de generación de cultura, y desde allí establecer una nueva manera de ver las cosas.

Los integrantes de la Generación crítica actuaron en varios frentes. Por ejemplo, el periodismo, desde Marcha — considerado el órgano oficial de todos sus integrantes- y más tarde desde las páginas culturales de diarios de amplia circulación como El País y El Día. También ejercieron sus puntos de vista desde sus profesiones liberales y desde la burocracia estatal, u ocupando diversos puestos clave dentro del campo intelectual. Y por último, en la educación, actuando desde su función docente en todos los niveles. Además,

\footnotetext{
... a medida que la educación fue alcanzando a sectores mayores del país y por lo tanto debió recabarse la colaboración de un mayor número de cuadros educadores, fue el profesorado la salida económica de la intelectualidad crítica y fue a través de las aulas donde se impartió un nuevo espíritu, más objetivo y más moderno, para encarar los problemas del país. Así se comenzó a instruir a las nuevas generaciones para un país distinto del que se vivía, con lo cual se provocó una violenta incorporación juvenil al esfuerzo renovador, crítico, que signaba a los profesores (Rama, 1971, pp. 386-387).
}

Nada mejor para diseminar su evangelio que adoptar una posición hegemónica de los entonces claves puestos docentes que formarían las nuevas generaciones, bajo el espíritu crítico y con multitud de nuevas ideas, que permitirían crear un público por el que ellos reclamaban día y noche en diversas manifestaciones.

Rodríguez Monegal comentaba que la mayor parte de los integrantes de la nueva generación tenían, como centro común de estudios, el Instituto Alfredo Vásquez Acevedo 
(IAVA), lugar al que volverían, años más tarde, como profesores de Literatura — como en el caso de Real de Azúa, Domingo Luis Bordoli, ${ }^{25}$ José Pedro Díaz, Guido Castillo, Idea Vilariño y Ángel Rama - y de Historia — como Pivel y muchos de sus mentores - ${ }^{26}$ Algunos de ellos también continuaron su labor docente en la Facultad de Humanidades y en el IPA (Rodríguez Monegal, 1966, p. 73). Rodríguez Monegal destacó, dentro de este grupo, la acción de Roberto Ibáñez, fundador del Instituto Nacional de Investigaciones y Archivos Literarios (INIAL) de la Biblioteca Nacional, y uno de los integrantes de la Generación crítica, quien desde su puesto en la Inspección de Literatura de Enseñanza Secundaria, influyó en la confección de los programas, introduciendo nuevas posturas entre los jóvenes docentes. ${ }^{27}$

Hacia 1955, ya inmersos en la crisis económica que siguió en Uruguay hasta los años setenta, observamos una división entre dos posturas intelectuales dominantes. Una serie de revistas, publicadas durante estos dos períodos, marcaron a fuego cada una de las promociones críticas a las que nos referimos. Un primer grupo que tendría como fecha de inicio 1947, integrado por Clinamen, Escritura, Asir, Marginalia y Número, publicaciones que tuvieron como factor común su poca inquietud social y política, por lo que las podríamos llamar como no comprometidas. Por otro lado, hacia 1954, Nuestro Tiempo, Nexo, Tribuna Universitaria y Estudios, vinculables a la segunda promoción de los críticos, aquellos que sí calificaríamos de comprometidos con la demanda de cambio social y político y que fueron denominados por Rama como la Generación de la crisis.

A continuación, intentaremos presentar un análisis de la situación editorial del Uruguay durante los años cincuenta.

\section{La crisis editorial de los cincuenta}

La idea que subsistió por parte de la Generación crítica, en las páginas de Marcha, fue que durante toda la década del cincuenta poco o nada se divulgaba en materia de publicaciones de escritores uruguayos, y que además la calidad de las lecturas eran malas, además del bajo nivel de lectura de la población.

\footnotetext{
${ }^{25}$ Bordoli (1919-1982) tuvo remarcada presencia en la crítica literaria gracias a su formación como docente, la cual le permitió hacerse cargo del grupo Asir y estar en la dirección de la revista desde 1949 hasta su último número. De formación católica, prefirió a los autores que siguieran su línea espiritual, como Zorrilla y Bauzá, para escribir muchos de sus trabajos críticos que le abrieron camino para obtener algún premio como ensayista por Vida de Juan Zorrilla de San Martín (1961). Su presencia no solo fue desde lo escrito, sino que también participó en programas radiales que tuvieron la literatura como norte (Real de Azúa, 1964, pp. 502-505). Fue autor de los prólogos de tres títulos de la Colección...: Motivos de Crítica de Osvaldo Crispo Acosta «Lauxar»; Selección de poesías de Romildo Risso, y Selección de cuentos de Yamandú Rodríguez.

${ }^{26}$ Sobre las redes intelectuales de Pivel, ver el Capítulo 3.

${ }^{27}$ Volveremos a hablar de él en el Capítulo 3.
} 
El diagnóstico hecho por los diversos críticos, durante los años cincuenta, fue que Uruguay vivía una crisis editorial. No solo era imposible editar libros, sino que tampoco había un público con aptitudes para la compra de lo que se escribía. La función de estos grupos intelectuales era crear su propio público lector, y Marcha fue el lugar elegido para llegar a tal fin.

Tomemos el ejemplo de Rodríguez Monegal (1953), quien analizaba la situación que vivían las letras nacionales y su imposibilidad de editar. El crítico consideraba que este cuadro de crisis no solo se debía a la insuficiencia de lectores, sino también a la falta de impulsos editoriales por parte del Estado.

Durante los años cincuenta, el problema editorial era constantemente mencionado por los escritores. La casi inexistencia de casas editoriales hacía muy difícil la publicación. Solo algunas de ellas subsistían gracias a la impresión de libros para la educación secundaria; otras realizaban apuntes mimeografiados para los estudiantes universitarios, y alguna otra editaba libros de prosa o verso, pero en general de autoría de los propios dueños de la editorial. En contraposición, Rodríguez Monegal (1953) rememoraba lo sucedido en el 900, cuando sí existían varios editores, y para los autores de la correspondiente generación, era posible tener un vínculo con los lectores. Dicha conexión era resultado del entonces considerable número de publicaciones.

El diagnóstico realizado para buscar el porqué de aquella situación, en la década del cincuenta, mostró que el alto costo de la producción partía de problemas que comenzaban con la materia prima, pasando por la falta de tecnología y por los gastos de distribución, además de las dificultades de circulación de capital en un mercado pequeño como el de Uruguay. Para peor, dicho mercado estaba inundado de libros extranjeros que eran más baratos que los impresos en el medio nacional.

Para hacer frente a este problema, se plantearon varias soluciones, desde distintas filas del círculo de producción literaria. La mayor parte de ellas reclamaba la exoneración de impuestos de las materias primas, en la distribución y para los capitales orientados a las empresas editoriales. Todas ellas, por tanto, planteaban como principal solución la intervención del Estado. La idea era abaratar el libro lo más posible, para competir con las importaciones desde América y España.

Desde este punto de vista, el libro debía estar al alcance de la población para que los potenciales compradores lo vieran como una inversión en cultura y no como un gasto innecesario. Según cálculos de Rodríguez Monegal (1953), el proceso de producción costaba en torno al $40 \%$ o $50 \%$ del precio final. Por otra parte, era necesario reducir el gasto en la 
distribución, ya que un libro que en Montevideo costaba $\$ 3,{ }^{28}$ llegaba a costar en Rivera cerca de $\$ 3,80$. Por último, los editores tenían en cuenta que atraer capitales para la industria editorial también era un problema, ya que se necesitaban entre seis y ocho años para que la inversión se recuperara.

Una de las soluciones que manejaba este crítico literario era crear una editorial estatal, pero no para que fuera utilizada con propósitos políticos, sino para compartir con los ciudadanos muchas de las obras de autores que nunca pudieron ser editados y cuyos derechos se encontraban en manos del Estado. Los ejemplos que mencionó fueron el de Carlos Vaz Ferreira y el de José Enrique Rodó.

Rodríguez Monegal sabía de los proyectos estatales, y claramente esta opinión era más un pedido o una exigencia que un comentario apuntado al azar. Como sabemos, este autor fue integrante del staff de prologuistas de la Colección...

Otro de los escollos señalados por Rodríguez Monegal (1953) era la escasez de público dispuesto a leer a escritores nacionales. Entre los uruguayos, nadie era tan leído en aquellos años como Francisco Espínola o Juan Carlos Onetti, quienes algunas veces agotaban sus ediciones, pero los libros de autores extranjeros como Jorge Luis Borges, Jean Paul Sartre, Franz Kafka y Antonio Machado, para nombrar solo algunos, también se agotaban.

Según muchos de los integrantes de la Generación crítica, al público había que crearlo mediante el ejercicio de la crítica. El crítico debería indicar al lector qué comprar. Ahora bien; si Uruguay se enorgullecía de tener un índice de analfabetismo bajo, los alfabetizados no eran sin embargo buenos lectores.

Rodríguez Monegal apuntaba contra una presunta cultura superficial, y disparaba irónicos comentarios contra aquellos que leían las novelas policiales del Séptimo Círculo y contra quienes compraban la revista Life en español, las tiras cómicas o simplemente los diarios, para concentrarse especialmente en las secciones deportivas. Finalmente sentenciaba:

\begin{abstract}
¿De qué sirve (de qué le sirve al poeta) vivir en una nación de alfabetos si esos alfabetos no leen, o leen solo los subproductos de una actividad literaria? La verdad es que no hay público para el escritor serio. O mejor dicho: no hay público bastante (Rodríguez Monegal, 1953).
\end{abstract}

Concluía con una posición marcadamente negativa, manifestando que la situación general de nuestra cultura tendería a empeorar, y que sería muy difícil que alguna vez apareciera un mercado para el escritor nacional. Nos interesa reparar en el concepto de escritor serio, que

\footnotetext{
${ }^{28}$ En 1953 un libro salía lo mismo que un cajón con 24 botellas de $330 \mathrm{~cm}^{3}$ de Coca Cola (Marcha, 17 de abril de 1953).
} 
creemos no sería otro que aquel integrado a la nueva generación de autores. Rodríguez Monegal consideraba que el problema no era del escritor sino del público lector. Esta idea de construir lectores será el mantra de los integrantes del 45.

Rodríguez Monegal consideraba necesario educar al lector, y nadie mejor capacitado para ello que esa nueva generación de personalidades que practicaban la crítica como una manera de militancia cultural, para socavar el conformismo intelectual de nuestro país.

Posteriormente, en un artículo publicado hacia fines de 1954 en Marcha, Rodríguez Monegal realizaba un racconto de lo sucedido en el país en referencia al ciclo de producción literaria, y lanzaba la pregunta «¿A dónde va la Literatura Nacional?». El copete de la nota parece demoledor:

... 1954 ha sido uno de los peores años para las letras nacionales. Un año de escasez y dificultades crecientes, de huelga gráfica y triunfo de la oficialización literaria, de seguro aumento del costo del libro y de parejo aumento de la reticencia del lector frente al producto nacional. Sería muy fácil inventar responsables y acusar a la gestión ministerial o a cierta Sociedad de Escritores (de cuyo nombre más vale no acordarse) ${ }^{29}$ de muchas de estas calamidades (Rodríguez Monegal, 1954, p. 17).

Para poner un ejemplo, durante el año mencionado, Marcha destacó que muy pocos escritores llegaron a editar, entre ellos el ya clásico Onetti, con una nouvelle como Los adioses; Clara Silva con Los delirios; Carlos Brandy con Los viejos muros, y Juan Cunha con Triple tentativa. En cambio, muchos otros no lo pudieron hacer, como Mario Benedetti o Idea Vilariño. Además, aquel también fue un año fatídico para las revistas literarias, puesto que muchas dejaron de publicarse, y otras lo hicieron con mucho retraso y con merma de sus actividades. Nombre se imprimió solo una vez; Número, en dos entregas, publicó tres números en vez de cuatro; Asir, que tendría que haber sacado al mercado ocho ediciones, tan solo pudo publicar tres, y por último Agón directamente desapareció. Como excepción, en este panorama para las letras uruguayas, Entregas de La Licorne planificó y puso en marcha tres de sus números, que salieron sin percances. Susana Soca, su directora, en su mecenazgo intelectual, podía hacer el esfuerzo económico del cual otras revistas estaban privadas. ${ }^{30}$ Sin embargo, la Colección de Clásicos Uruguayos, dirigida por Pivel, había sacado cuatro tomos a la calle, ${ }^{31}$ lo que marcaba la importancia que estaba adquiriendo la publicación estatal.

\footnotetext{
${ }^{29}$ En referencia a la Asociación Uruguaya de Escritores (AUDE).

${ }^{30}$ Para más información sobre la vida y obra de Susana Soca al frente de su revista La Licorne en sus dos épocas (París y Montevideo), ver Amengual (2012).

${ }^{31}$ Estudios Filosóficos de José P. Massera, Paja brava de El Viejo Pancho, Doñarramona de José Pedro Bellán y Soledad y el Combate de la tapera de Eduardo Acevedo Díaz.
} 
El problema para publicar era constantemente reiterado por Marcha: los altos costos de la producción total hacían imposible la impresión. Además, el Estado se mostraba inepto frente a esta situación. La falta de fomento y las desacertadas intervenciones estatales no pudieron resolver el problema durante toda esa década. ${ }^{32}$ La prueba de dicha imposibilidad era que incluso muchos de los autores ya conocidos debían apelar a editoriales extranjeras para publicar. Por ejemplo, la ya consagrada Juana de Ibarbourou publicaba en Buenos Aires o en Madrid.

Al escritor le parecía muy difícil publicar, ya que el público lector prácticamente no existía, y pedir préstamos o hacer esfuerzos económicos importantes no era atractivo vista la situación del momento. Podemos concluir que, según algunos integrantes de la Generación crítica, en los años cincuenta las formas dominantes de conexión entre los escritores y el público lector fueron los diarios y revistas.

Sin embargo, sabemos que la Colección... tuvo un importante rol dentro del mundo editorial nacional. Desde 1953 hasta 1959 habían salido al mercado un total de 28 tomos y alrededor de 112.000 ejemplares. Sin embargo, si bien el número de títulos fue abrumador para la época, la prensa periódica de los años cincuenta fue indiferente a la serie editada por el Estado. En cambio, luego dejará de ser ignorada, ya que varios integrantes de las páginas literarias de Marcha también actuarán como prologuistas en los sesenta, sobre todo durante la estadía de Pivel en el Ministerio de Instrucción Pública y Seguridad Social.

\section{La Feria del Libro, la solución de los sesenta y el boom editorial}

La palabra boom no era del gusto de Julio Cortázar, quien consideraba inapropiado el uso de un anglicismo para un fenómeno latinoamericano e hispanohablante. Esa explosión trascendió en la historia literaria como el momento en el que un importante grupo de escritores de América Latina se hicieron conocidos a nivel mundial gracias al aumento en las ventas de sus libros. ${ }^{33}$

En Uruguay, ya desde la década del cuarenta, se reclamaba desde diversos ámbitos de la cultura una intelectualidad más conectada con el mundo cotidiano del lector, y que llevara a

\footnotetext{
${ }^{32}$ Constantemente, desde diversos órganos de prensa y publicaciones periódicas, los integrantes de la Generación crítica se quejaban de los premios ministeriales que se entregaban a los autores, con pequeñas sumas calificadas de limosnas, que impedían el pago de una edición.

${ }^{33}$ Estos años fueron de fermento cultural y de un gran optimismo revolucionario, intrínsecamente conectado con las noticias que desde Cuba comenzaban a resonar en todo el continente, y a reorientar la mirada geopolítica de los Estados Unidos y del resto del bloque capitalista. La Revolución Cubana merece ser tomada como un mojón importante en el ambiente cultural uruguayo. Aquello que los intelectuales proclamaban desde la cultura tenía su correlato en la política. El triunfo de una revolución popular, mediante las armas, contra un enemigo directamente conectado con una de las potencias hegemónicas en aquel mundo bipolar, parecía demostrar que comprometerse con la realidad y esforzarse por cambiarla podía rendir sus frutos. Cuando Cuba se pasó definitivamente al bloque socialista, en abril de 1961, la Guerra Fría terminó de impregnar el ambiente intelectual y político regional. Ver Marchesi (2019).
} 
cabo una obra en la cual el lector pudiera reconocerse. Durante los años del boom, este tipo de obras empezó a salir a la luz, y el público lector comenzó a ampliarse comprando cada vez más ejemplares.

Rodríguez Monegal comentaba, sobre la realidad de la literatura uruguaya en los sesenta, que a nivel económico Uruguay no tenía peso en el mercado literario, pero que había algunas iniciativas que certificaban su pretensión de existencia:

- La Feria del Libro inaugurada en el Palacio Municipal a fines del año pasado y que demostró que hay un público para ciertos autores nacionales;

- El éxito de la colección Letras de hoy (dirigida por Ángel Rama, editada por Benito Milla, de la Editorial Alfa) que reúne textos de nuevos y consagrados escritores nacionales;

- La fundación de la Editorial Asir (con gente de esta revista y de la revista Número) para publicar con sentido cooperativo autores uruguayos;

- Una iniciativa del Banco de la República (Préstamo para Ediciones Uruguayas de Interés Cultural) que mejora las condiciones económicas con que un escritor puede solicitar un crédito. [...] Sin embargo, la situación sigue siendo negra (Rodríguez Monegal, 1961).

En enero de 1960 tuvo lugar la primera edición de la Feria Nacional del Libro y el Grabado, realizada en el atrio de la Intendencia Municipal de Montevideo. Gracias a un crecimiento sostenido de asistentes, la Feria demostró a los libreros de Uruguay que el libro nacional podía ser tan buen o mejor negocio que el extranjero. En consecuencia, como señala Torres Torres (2012), los libreros empezaron a exhibir muchos más libros uruguayos en sus locales e hicieron la publicidad correspondiente, que no había existido durante los años anteriores. La aparición de dos sellos editoriales en el medio nacional — Alfa y Asir — habilitó el inicio de las ediciones comerciales para la nueva generación, y facilitó el alejamiento de los escritores de la necesidad de publicar libros pagados por ellos mismos.

Según cálculos presentados por Maggi para la Encliclopedia uruguaya, con el año 1959 como referencia, sobre la base de cien títulos de publicaciones uruguayas, con un tiraje de unos quinientos ejemplares cada uno, la cantidad de libros vendidos estuvo en torno a los cincuenta mil. En cambio, hacia 1967, sobre unos doscientos títulos en el mercado, con un tiraje de 2500 ejemplares cada uno, la cantidad de libros vendidos se ubicó en el medio millón. El aumento exponencial de las ventas, durante esos años, muestra la importancia del fenómeno del consumo del libro ocurrido en Uruguay (Maggi, 1968, pp. 33-41).

Como dato estadístico, el crítico uruguayo destacaba que «un ejemplar del semanario Marcha del mes de diciembre de 1967 contiene más de veinte grandes anuncios que publicitan 
la venta de libros nacionales, cuando el total de anuncios de este difundido semanario no pasa de treinta» (Maggi, 1968, p. 38). Además, el precio de algunos de los libros editados por la editorial Alfa en esos años costaba lo mismo o menos que una entrada de cine, o incluso el equivalente a dos limones (Maggi, 1968, p. 38).

Sin embargo, y en contradicción a lo afirmado por Torres Torres (2012), Maggi señalaba que los factores que ayudaron al resurgimiento de la industria editorial uruguaya fueron resumidos en la conformación de un nuevo público lector por parte de la Generación crítica, las ayudas económicas del Estado a través de préstamos del Banco República, la coyuntura económica, política y social nacional e internacional enmarcada en las consecuencias que produjo la Revolución Cubana, y las diversas iniciativas privadas para llevar a cabo la venta de libros de autores uruguayos como la Feria del Libro.

En la primera Feria, hubo pocas expectativas de venderle al público los libros uruguayos remanentes de la producción de 1950 a $1960 .{ }^{34}$ Fue una gran sorpresa que, en el día de la inauguración, se vendieran veinte mil pesos en mercadería, lo que equivalía a unos tres mil volúmenes. ${ }^{35} \mathrm{Si}$ bien las ventas se sostuvieron, Rama propuso algunos cambios que fueron tenidos en cuenta luego por los organizadores. Para el intelectual uruguayo, el mes elegido para desarrollar el evento fue equivocado: diciembre era un mejor momento para poner en marcha el proyecto, debido a la cercanía con las fiestas y al cobro de los medios aguinaldos - lo que hubiera generado una mayor cantidad de ventas - Entre los escritores más vendidos estuvieron Serafín García, Osiris Rodríguez Castillo, Juan Carlos Onetti, Mario Benedetti, Horacio Quiroga, Joaquín de Viana, Enrique Amorim y Felisberto Hernández (Rama, 1961).

En consecuencia, y para dar un ejemplo, a partir de 1962 se pudo observar en las páginas de Marcha que el número de noticias sobre escritores uruguayos y sus obras iría en aumento, ya que antes la mayor parte de las notas literarias tenían como asunto a los extranjeros, debido a la poca producción de libros nacionales.

De manera contemporánea al éxito de las ferias de libros, surgieron algunas medidas tendientes a favorecer la aparición de empresas editoriales. Así, para ayudar a los escritores a concretar sus obras, Felipe Gil — director del Banco República—, Carlos Maggi — abogado del banco-y Ángel Rama redactaron una ley denominada “de Préstamos al Autor Nacional”. Para recibir el dinero, el autor debía presentar su texto, y éste ser aceptado por una comisión integrada por Rodolfo Tálice (Facultad de Humanidades de la Universidad de la República), Francisco Espínola (Ministerio de Instrucción Pública y Seguridad Social), Washington de

\footnotetext{
${ }^{34}$ Es interesante notar que, si bien desde la Feria se pusieron a la venta discos y grabados uruguayos, los primeros no tuvieron mucho éxito, ya que la producción era muy escasa en el país. En cambio, los grabados tuvieron una buena acogida, superando las expectativas.

${ }^{35} \mathrm{La}$ Feria tuvo una duración de veinte días y la visitaron más de veinte mil personas (Rama, 1961).
} 
María (Banco República) y Carlos Maggi, como secretario. Luego abrirían una cuenta corriente para que el autor operara junto con los demás integrantes de la empresa -impresor y encuadernador, entre otros- El interés que se le cobraría sería de un $5 \%$, y las amortizaciones serían en varios años. Como garantía se tomaría el sueldo del titular o un tercio de lo pedido. Esta solución fue solicitada por numerosos autores que se vieron beneficiados. Estos préstamos permitieron la multiplicación de las obras uruguayas, aunque no implicaba un beneficio económicos para los autores.

Rodríguez Monegal recordaba una anécdota de Benedetti para ilustrar el poco margen de ganancia que los libros de Uruguay daban a sus autores: en un diálogo entre el escritor uruguayo y una periodista argentina, la cronista le preguntó cómo hacían los escritores para vivir de lo que vendían, hecho que resultaba imposible en nuestro medio según el autor, ya que siempre había que tener un trabajo público o de otro tipo. El país de la cola de paja fue best-seller ni bien salió a la venta. Con la primera edición, que fue cooperativa, Benedetti no ganó nada (Ediciones Asir, 1200 ejemplares), en la segunda ganó \$ 1700 (Ediciones Ciencias, 2000 ejemplares), y la tercera le dejó \$ 2000 (Ediciones Ciudad Vieja, 2000 ejemplares). En casi nueve meses se vendieron las tres ediciones. El escritor tomó como referencia que un contador podía llegar a ganar, haciendo contabilidades sueltas, cerca de $\$ 4000$ al mes (Rodríguez Monegal 1961), lo que permitió una buena comparación con su labor como escritor de bestsellers.

Respecto de los nuevos lectores que empezaron a impulsar las ventas durante la década del sesenta, Benito Milla ${ }^{36}$ — editor, librero, director de la revista Deslinde, creador de la editorial Alfa - creía que existía un nuevo público lector entre la gente joven, que era la misma que apoyaba el fenómeno cineclubístico y los teatros independientes. Sostenía que dicho público

...es un lector especializado que lee a aquellos escritores en los que se refleja viva la problemática actual. De ahí el interés que ha despertado la colección Letras de Hoy. En cierto sentido, es un lector que ha sido formado por los mismos escritores que lee, esa generación del 45 que irrumpió en la literatura uruguaya con un sentido más vivo y polémico del arte literario.

En vez de situarse en el Olimpo y escribir para la posteridad, el escritor del 45 hizo periodismo y crítica literaria, fundó revistas, dio conferencias y participó en mesas redondas, escribió hasta en las paredes y fue a buscar al lector a su cueva. Pero sobre todo lo hizo hablando con él los problemas que le interesaban vitalmente, examinando el mundo en que tanto el autor como el lector están inmersos. Hizo del lector su cómplice (Milla en Rodríguez Monegal, 1961).

\footnotetext{
${ }^{36}$ Ver más en Torres Torres (2012).
} 
Para agregar, Rodríguez Monegal citó a Ángel Rama, quien a su vez definió a ese nuevo público como de

... origen burgués, intelectual en sus actitudes básicas y hasta generacional por sus gustos. Es cierto que ese público también ha agotado ediciones de gente mayor, como Espínola, Juan Carlos Onetti, Morosoli, Felisberto Hernandez y Enrique Amorim. Pero precisamente lo que une a estos escritores mayores con los del 45 es una actitud similar frente a la materia literaria y, sobre todo, frente al problema de la comunicación con el lector (Rama en Rodríguez Monegal, 1961).

Si bien estos comentarios que citamos no son objetivos, ya que pretenden legitimar su propia tarea como intelectuales, Rodríguez Monegal consideraba que, para terminar de acercar al lector y al autor, era necesario contactar al primero mediante un instrumento idóneo como la revista literaria.

El crítico literario reconoció, para su autoconsagración, que otro de los puntos que permitió la proximidad entre escritura y lectura fue el papel de la crítica, refiriendo un caso en que «una reseña violenta» - Ruben Cotelo en El País — provocó una segunda edición del libro de Benedetti El país de la cola de paja.

Sin embargo, el problema fundamental seguía siendo económico, ya que era muy caro editar, y se mencionaba que se vivía en una especie de siglo XVIII europeo, por lo artesanal de la producción y porque el escritor debía asociarse con el librero y compartir ganancias o pérdidas. Además, no se podía hacer un catálogo de todos los libros editados, ya que, para ello, era fundamental conformar una colección de libros, por lo que era necesario contar con un capital:

Hay aquí un círculo vicioso. Para vender libros hay que hacer propaganda, pero para poder hacer propaganda hay que tener dinero y para tener dinero hay que vender libros [...] Cuatro avisos en cuatro de los más importantes diarios de Montevideo costarían lo mismo que toda la edición del libro (Rodríguez Monegal, 1961).

Por lo tanto, Rodríguez Monegal seguía insistiendo en que la única solución eran las editoriales estatales. Ese sería el caso de lo que quiso hacer Pivel desde un proyecto que presentó ante el Consejo Departamental, a través de la Dirección de Artes y Letras, en el que planificaba la fundación de una Editorial Municipal, que finalmente fue creada en 1958, pero que no llegó a publicar nada debido al magro presupuesto asignado de sesenta mil pesos, que no alcanzaba ni para iniciar las tareas. Pivel expresó que su proyecto de subsidio estatal era la única solución al 
problema. El historiador quería emular lo sucedido en México con el Fondo de Cultura Económica, que dependía del banco oficial y que se convirtió en uno de los principales sellos editores de la América hispanohablante (Rodríguez Monegal, 1961; Sorá, 2017).

Respecto a los préstamos bancarios, Pivel no veía en ello una solución:

- Parece una broma. Obligar al escritor a seguir practicando la gimnasia de los préstamos. Pero si van ciegos a la Caja Nacional. Que pongan ese millón como capital inicial de una editorial y entonces será otra cosa. Hay que evitar que el escritor siga siendo editor de sus libros. Mire, yo publiqué un libro una vez y lo tenía apilado aquí (señala un rincón, también cubierto de ejemplares). Cada amigo que entraba se llevaba uno; no se lo podía negar.

Editar un libro no significa solo imprimirlo. También hay que distribuirlo en librerías, también hay que enviarlo al interior y al exterior, también hay que comercializarlo. El escritor no puede ocuparse de eso. Si se ocupa, entonces deja de ser escritor para convertirse en editor. Pivel insiste, habla, se apasiona. Le recuerdo que en un artículo de El País calificó al préstamo de una aspirina para el cáncer. Me irrumpe con vehemencia:

- Sí, pero una aspirina de oro.

- La solución está en una editorial del Estado, o financiada por el Estado. Pivel habla y sus proyectos van tomando forma. Se podría editar una colección de clásicos uruguayos, que tendría salida permanente y ayudaría a compensar las pérdidas provocadas por algunos libros nuevos. La Biblioteca Artigas no tiene fondos y está dependiendo de los benditos duodécimos de presupuesto reducido. Se podrían hacer ediciones de clásicos universales.

-No se ha hecho nunca un Quijote uruguayo, me dice. Yo creo que el Estado no perdería y hasta podría ganar. Pero habría que organizarlo todo de otra manera. Hay que fundar un Instituto del Libro, como tienen en Brasil, donde están organizados admirablemente. No hay que pensar en soluciones pequeñas y tímidas, de corto alcance. Hay que plantear en grande y el Estado tiene la obligación de hacerlo (Entrevista a Pivel en Rodríguez Monegal, 1961).

El análisis y la solución planteados por el historiador eran coherentes con toda su obra hasta ese momento, y con su posterior actividad como ministro dos años más tarde. Como sabemos, finalmente se editaron los clásicos universales y se publicó un Quijote uruguayo, ${ }^{37}$ pero su trascendencia no fue acorde al planteo inicial, y una vez terminado el período de Pivel en el Ministerio, los Clásicos Universales ${ }^{38}$ dejaron de aparecer.

Sin embargo, vale la pena recordar que, hacia 1965, con Pivel al frente del Ministerio de Instrucción Pública y Previsión Social, fueron introducidos varios cambios en la normativa vigente para el abaratamiento de la producción de libros en nuestro país. En el artículo 45 de la Ley 13319, se puede leer:

\footnotetext{
${ }^{37}$ Sin embargo, no fue el primero, ya que en 1880 la Imprenta de La Colonia Española había hecho uno. No sabemos si Pivel tenía conocimiento de esta primera edición, o si ignorarla era una buena idea para buscar fondos.

${ }^{38}$ Ver anexo con la lista de títulos.
} 
A partir de la promulgación de la presente ley, quedan exoneradas del pago de cualquier impuesto, tasa o contribución, la impresión de libros y folletos de autores nacionales y la venta de libros, revistas de carácter literario, científico, artístico, docente, así como material educativo. ${ }^{39}$

Al decir del Ministro, dicha disposición legal «resultó ambigua, de interpretación difícil, e inconducente en su aplicación. Por eso recurrimos al expediente de proponer un artículo sustitutivo, en la primera oportunidad que se presentó» (Castro, 1965). Esa oportunidad fue el 29 de junio de 1965, cuando el artículo 79 de la Ley 13349 modificó el anterior, estableciéndose el siguiente texto:

Los talleres gráficos, empresas editoriales y librerías, en la parte de su giro relativa a la impresión y venta de libros, folletos y revistas de carácter literario, científico, artístico, docente y material educativo, estarán exonerados de los impuestos que gravan sus capitales, ventas, entradas, actos, servicios y negocios, con exclusión de los impuestos a la renta.

Dichas empresas deberán abonar tales impuestos cuando recaigan sobre bienes que no estén directamente afectados al giro que da mérito a esta disposición y sobre ventas, entradas, actos y negocios, de cualquier índole, que no se relacionen directamente con el cumplimiento del giro exonerado. [...]

Las materias primas para la fabricación de papeles y cartulinas cuyo destino exclusivo sea la impresión de las publicaciones y material educativo arriba expresado gozarán de la exoneración de todos los impuestos que gravan su importación. La fabricación y comercialización de dichos papeles y cartulinas se beneficiarán de las exoneraciones indicadas en los incisos precedentes.

Los fabricantes reducirán en un $30 \%$ (treinta por ciento) los precios de venta al público, vigentes al $1 .^{\circ}$ de mayo de 1965 , de los papeles y cartulinas cuyo destino sea la impresión de las publicaciones y material educativo mencionados, no disminuyendo en ningún caso la calidad de cada tipo de papel o cartulina.

Los talleres gráficos, empresas editoriales y librerías aplicarán los papeles y cartulinas favorecidos con el descuento arriba indicado exclusivamente para la impresión de las publicaciones y material educativo ya expresados. ${ }^{40}$

Para aplicar dicha medida, el Estado creó la Comisión del Papel, que contaba con representantes del Poder Ejecutivo como los Ministros de Industria, de Instrucción Pública y de Hacienda. Desde el sector privado estaba integrada por fabricantes de papel e impresoras. Por estos medios, el Estado buscó, y finalmente consiguió, el abaratamiento del libro nacional.

\footnotetext{
${ }^{39} \mathrm{http} / / /$ www.parlamento.gub.uy/leyes/AccesoTextoLey.asp?Ley=13319\&Anchor= ${ }^{40} \mathrm{http}$ ://www.parlamento.gub.uy/leyes/AccesoTextoLey.asp?Ley=13349\&Anchor=
} 
En su primer detalle anual, la comisión informó que de las 61 empresas que se registraron, 22 hicieron uso de las facilidades. En total, dichas organizaciones editoriales imprimieron, contando libros y revistas, 1.256.926 ejemplares. Las publicaciones por rubro fueron expuestas de la siguiente forma: literatura —menos poesía—, 40; historia, 29; poesía, 22; derecho, 19; matemática, 14; libros de lectura, 12; pedagogía, 12; otros tipos, más de 10 (Castro, 1965).

La comisión se encargaba de desgravar la fabricación de papeles nacionales, y como consecuencia, el precio bajó un $30 \%$, lo que puede ser traducido, en referencia a una publicación de entre quinientos y dos mil ejemplares, a una baja del $10 \%$ del costo. También, para más de cinco mil impresiones, la comisión calculaba que podía llegar a un $20 \%$. La eficacia de dicha baja llegaba en general a libros escolares o liceales, y no tanto al resto de las obras en el mercado. Rama reconocía la importancia de los cambios en los precios, pero no creía que fuera la solución definitiva. El crítico uruguayo hacía el siguiente razonamiento: de un libro que costaba alrededor de $\$ 140$, gracias a la ley pasaba a valer 126 , y eso no era tanta rebaja como para que el público se lanzara ávido a comprar ejemplares en gran cantidad (Rama 1966).

Todas estas actividades ayudaron, cada una desde su respectiva posición, no solo a abaratar el precio del libro en Uruguay, sino también a generar un nuevo mercado, que permitió su expansión durante los años sesenta.

\section{El final de un ciclo}

Durante 1972, y como consecuencia del Año Internacional del Libro, en el auditorio Carlos Vaz Ferreira de la Biblioteca Nacional, se realizó, durante dos horas, un coloquio que versaba sobre los problemas que existían para la publicación e impresión de libros, y que llevó por título Una política nacional del libro (AA.VV., 1972). Lo interesante de la reunión fue que se invitó a personas involucradas en los distintos procesos de producción para que vertieran sus opiniones y diagnósticos sobre los problemas de los últimos veinte años. Los participantes fueron Fernando Aínsa, Guzmán Barreiro, Nilya Ziegler, Julio C. da Rosa, Ignacio Espinosa, Héctor D’Elía, Manuel Irisarri, Julio César Jauregui, Jorge Riet y Arturo Sergio Visca. ${ }^{41}$

\footnotetext{
${ }^{41}$ Visca (1917-1993) es definido resumidamente como un «antiguo estudiante de medicina y aprendiz de revolucionario, aspirante a narrador, [...] encontró en el correr de los años, su auténtica vocación en la crítica y el ensayo [...]. Visca ha concentrado casi exclusivamente su labor en la literatura nacional, de cuyo sector narrativo, especialmente, es con seguridad el más completo conocedor» (Real de Azúa 1964, p. 489). Participó en varias publicaciones llevadas a cabo por la Generación crítica como Asir —en su consejo editorial一, escuetamente en Marcha, también en Entregas de la Licorne, y estuvo al frente de la página dominical de El País en su sección literaria, entre otras. Fue uno de los más prolíferos prologuistas de la Colección... Llegó a publicar nueve prólogos dentro de nuestro período de estudio: Gaucha, y una selección de cuentos de Javier de Viana; Pasar de Mateo Magariños Solsona; Cuentos de Benjamín Fernández y Medina; Ensayos de Carlos Reyles; Antología de Fernán Silva Valdez, Crónicas de un crimen de Justino Zabala Muniz, Anecdotario del uruguayo Santiago Marcos; y
} 
Al comienzo de la discusión, el tópico abordado fue el de los libros extranjeros, los que en su mayoría no llegaban a nuestra plaza, y mucho menos aquellos no traducidos al español. Los lectores estaban bastante desinformados de lo último que se publicaba en las diversas áreas en Hispanoamérica. El ejemplo que propuso Visca, teniendo en cuenta un best-seller latinoamericano, fue el libro que escribió, en 1971, Mario Vargas Llosa sobre Gabriel García Márquez (García Márquez: historia de un deicidio), el cual, luego de seis meses de publicado en la mayoría de los países del continente americano, no había llegado aún al Uruguay. Ello era visto como demostración del peligroso aislamiento cultural del país, y también como una variable del descenso del nivel cultural en Uruguay.

Lo más llamativo de la reunión era la sensación de nueva crisis en la publicación nacional, que años posteriores se hizo realidad como consecuencia del golpe de Estado de 1973. En cambio, en Una política nacional del libro (1972) se destacó que el mejor período para la venta y producción de libros fue entre 1965 y 1967. Posteriormente comenzó un declive que hacía recordar los problemas enfrentados durante los años cincuenta. El ex presidente de la Comisión Nacional del Papel, Julio César Jáuregui, recordaba que

\begin{abstract}
... en el 65, en el 66 y en el 67 nos leíamos todo lo que podíamos leer escrito por nosotros. Ya no podíamos leer más, porque se leían todos los libros: el mercado interno se vio plenamente satisfecho, tan satisfecho, que los editores recogían libros viejos para darlos a la plaza, porque el autor no producía en la misma proporción, porque no puede vivir de solo escribir (AA.VV., 1972, p. 25).
\end{abstract}

En referencia a la mirada que tenían los impresores respecto del mismo problema, los invitados al coloquio hablaron sobre la necesidad de contar con operarios mejor capacitados para el proceso, y se reparó especialmente en la lentitud y en lo caro de la producción debido a que el país estaba rezagado a nivel tecnológico. Las máquinas quedaban viejas u obsoletas en un par de años y era muy difícil, por parte de los impresores, hacerse de nuevos equipos por lo costoso que resultaba invertir en ellos.

Por último, estos expertos en la producción de libros hablaron del papel. La producción de papel en Uruguay no daba para la demanda que había de él, y eso causaba que muchas veces los libros no se pudieran imprimir, lo que al parecer del representante de la Asociación de Impresores del Uruguay, el ingeniero Guzmán Barreiro, era

...gravísimo, porque frente al esfuerzo de una cantidad de elementos que intervienen en la publicación del libro, nos encontramos con la falla de uno de

Lauracha de Otto Miguel Cione. Una vez instaurada la dictadura siguió trabajando en la Biblioteca Nacional como su director. 
los eslabones más importantes de la cadena, que es la materia prima para poder realizar la impresión (AAVV, 1972, p. 15).

Manuel Irisarri, de la Asociación de Fabricantes de Papel, manifestó que el mayor problema que encontraba era la imposibilidad de importar materia prima para la producción del papel y que, para ello, eran necesarios los dólares que el Banco Central debería otorgar, ya que la imposibilidad de obtener las divisas necesarias para la importación hacía imposible su fabricación. Por último, Irisarri fijó el comienzo de la crisis del libro luego de 1965.

Sorprende ver, en diálogo con el catálogo de la Colección..., la relación entre la producción de libros por parte de las series de libros privadas y las del Estado. Como veremos en el capítulo 4, durante los años de mayor producción de libros nacionales, la Colección... acompañó con la cantidad de títulos editados y los grandes tirajes. El mercado asumió, a través del consumo, las obras contemporáneas y los clásicos de la literatura y la historia uruguayas.

Volviendo al coloquio, para la promoción de la lectura de los libros, desde la Escuela Universitaria de Bibliotecología y Ciencias Afines — representada por Nilya Ziegler- era necesario promocionar los libros nacionales y crear más y mejores bibliotecas, ya que se consideraba eran insuficientes y muy desactualizadas, además de contar con material poco interesante para los lectores. Ignacio Espinosa resaltó la necesidad de crear dichas bibliotecas para intentar generar un mercado interno fuerte y, luego, como una evolución natural, recién apuntar a la exportación de libros, aspecto que veía lejano debido a las condiciones económicas de nuestro país y a la importante competencia de grandes centros editoriales como los de Buenos Aires, México y España.

Julio C. da Rosa, en oportunidad de señalar su opinión como escritor, marcaba la imposibilidad de los autores de vivir de su trabajo, ya que las políticas nacionales del libro no permitían expandir la producción a otros países de habla hispana, expansión que podía dar chance a los escritores uruguayos de sobrepasar el escaso mercado nacional de no más de dos millones y medio de personas, el cual, para quienes más publicaban representaba aproximadamente dos mil lectores.

Claro que, otra vez, las soluciones para gran parte de los asistentes debían ser desarrolladas, o por lo menos planteadas, por el Estado. Todavía existía una visión puramente estatista o, en términos de nuestro medio, «batllista», para encontrar una solución, aspecto que mostraba una importante contradicción. Si bien muchos de los exponentes no eran las personalidades más representativas de la Generación critica, al leer sus alocuciones reconocemos muchas de las ideas no eran originales, podemos verlas repetidas durante los años sesenta por el semanario Marcha. 
Finalmente, el golpe de Estado de 1973 cortó de raíz tanto lo planteado por los participantes de dicho congreso como el libre desarrollo cultural en el Uruguay. Hacia los años setenta y comienzos de los ochenta, el panorama era absolutamente distinto. Gran parte de la intelectualidad tuvo que emigrar. El exilio fue la carta más jugada por muchos de los integrantes de la Generación crítica en sus dos promociones. Otros no corrieron esa «suerte», y fueron desaparecidos por los militares - como el maestro Julio Castro, solo para citar uno de los nombres que colaboraron con Marcha.

La censura del gobierno de facto comenzó a aplicarse con más ferocidad meses después del golpe. Marcha fue cerrado en 1974. La dictadura hizo imposible el natural desarrollo del campo cultural uruguayo, y ese corte abrupto ha mostrado sus consecuencias nefastas hasta nuestros días.

Luego de 1973, el Ministerio de Instrucción Pública - llamado de Cultura durante esos años - y el resto de las instituciones culturales, fueron intervenidas. Sin embargo, Pivel se mantuvo como Director del Museo Histórico Nacional (MHN). Ese puesto, dentro de la administración, le permitió continuar en la Comisión de la Colección...

En 1982, como consecuencia de las negociaciones entre los partidos políticos y el gobierno dictatorial, Pivel renunció a su cargo, ya que fue uno de los representantes del Partido Nacional en la mesa de diálogo. ${ }^{42}$ Años después, y con la llegada de la democracia, el historiador volvería a los cargos públicos, pero ya al frente del órgano rector de la educación pública.

En el siguiente capítulo, consideraremos diversas caras de Pivel: historiador, político, administrador, editor y prologuista, como uno de los protagonistas más importantes de la cultura en el Uruguay de los últimos cincuenta años del siglo XX.

${ }^{42}$ Ver Capítulo 3. 


\section{CAPÍtULO 3}

\section{“COMO PIVEL NO haY". Un INTELECTUAL AL SERVICIO DEL ESTAdO NACIONAL}

En el Uruguay de los años cincuenta, alentado por ciertos éxitos deportivos a nivel internacional y un relativo bienestar económico (Frega, 2008), se creía en la excepcionalidad del país con respecto al resto de los países latinoamericanos. Una de las expresiones más repetidas por aquel entonces, además de la autoconsideración como la "Suiza de América", era: "como el Uruguay no hay". El título de este capítulo juega con dicha consideración, ya que la posición hegemonizante de Pivel comienza a ejercerse en la mitad del siglo XX; si Uruguay era una excepción, Pivel, dentro del campo intelectual, comenzaba a construirse como tal.

El intelectual posee parte del capital cultural, dentro del campo de poder, pero a su vez es dominado por la clase dominante (Bourdieu, 1999). Es desde este aspecto fundamental que debemos entender al intelectual en sus diferentes posiciones y decisiones dentro del campo cultural. Sin embargo, no todos los intelectuales cuentan con el mismo capital simbólico —que depende de su autoridad, poder o prestigio - para definir la cultura legítima (Altamirano, 2013, p. 97).

Este capítulo intenta estudiar la intensa actividad intelectual de Pivel, identificando las instituciones y los intelectuales que permitieron que su discurso se convirtiera en dominante a nivel historiográfico y cultural. También pretende trabajar sobre su periplo biográfico - gracias a su militancia política, a su actividad como funcionario estatal y a sus redes intelectuales - como ejemplo de intelectual de derecha. Además, observaremos cómo Pivel asumió su rol como agente de producción de significados, en convergencia con las corrientes conservadoras de la época. Finalmente, nos interesa ver cómo, una vez asentado como autoridad oficial estatal, se desenvolvió en su función de editor de la Colección..., desde donde afianzó su proyecto cultural conservador.

Juan Ernesto Pivel Devoto, hijo de Juan Pivel — de supuesto origen vasco-francés ${ }^{43}$ - y de Laura Devoto — hija de italianos ${ }^{44}$ —, nació en 1910 y se crió en un hogar de clase media en

\footnotetext{
${ }^{43}$ Según cuenta su hijo Juan Pablo, los Pivel serían originarios de la región de Lorena. Véase, Entrevista a Pivel.

${ }^{44}$ Los Devoto serían de Chiavari, un pueblo cerca de Génova. Véase, Entrevista a Pivel.
} 
el departamento de Paysandú (Vidaurreta, 2001, p. 17). Fue un autodidacta orgulloso en momentos en que no existían aún ni la Facultad de Humanidades y Ciencias de la Educación, creada en 1945, ni el IPA, fundado en 1949, centros donde se forman hasta el día de hoy a historiadores y docentes de Historia. Pivel se dedicó desde los 18 años a la docencia, actividad en la cual se desempeñó hasta 1982, cuando fue destituido por la dictadura cívico-militar.

Además de su obra como historiador, es necesario agregar su tarea como editor, que incluye las 44 entregas de la Revista Histórica, los 28 volúmenes del Archivo Artigas y los 165 tomos de la Colección de Clásicos Uruguayos (1953-1982) en los que, como ya señalamos, tuvo responsabilidad directa.

Su primer contacto con la Historia fue a través del Ensayo de historia patria (1913) de HD - Hermano Damasceno, seudónimo de Gilberto Eduardo Perret—, libro que le sirvió de manual a todos los estudiantes de educación primaria y media, y en el que se establecen los pilares de la Historia “nacional” y “patriótica” (Palomeque, 2012; Sansón, 2011b).

Pivel recuerda en una entrevista hecha por Vidaurreta que los primeros libros no escolares que leyó fueron Tabaré y La Leyenda Patria de Juan Zorrilla de San Martín (Vidaurreta, 2001, p. 20). ${ }^{45}$ Debemos remarcar que Vidaurreta se transforma en su biógrafa ya que el trabajo editado primeramente en Estados Unidos ${ }^{46}$ intentó realizar, sobre la base de un diálogo entre el protagonista y su ex colaboradora, iniciado en 1955, una semblanza de la personalidad intelectual de Pivel. Es la más extensa entrevista que se le realizara. Este libro fue tomado como una fuente importante para observar las redes intelectuales pivelianas, conformadas en los primeros años de su carrera como investigador. También resulta un importante documento porque constan, en los papeles de Pivel en el Archivo General de la Nación —en adelante AGNU-, varias copias con las correcciones hechas por el protagonista de la entrevista. Esto supone la construcción de un libro autobiográfico, que puede ser visto como una forma de autoconsagración.

Prosiguiendo con la semblanza de Pivel, a los ocho años, con un grupo de compañeros, decidió publicar el periódico El Uruguay, en donde comenzó escribiendo sobre personajes históricos, ayudado por el libro de HD. Uno de los primeros fue Leandro Gómez, héroe blanco de la resistencia en Paysandú frente al ejército reunido por el colorado Venancio Flores en 1865.

Durante el batllismo, su familia tuvo un buen pasar económico, lo que le permitió viajar a Montevideo en 1919, en donde se instaló a estudiar en los Talleres Don Bosco, de enseñanza religiosa y privada. Pivel cuenta, construyendo su imagen de self made man, que en aquellos

\footnotetext{
${ }^{45}$ Estos libros lo marcaron durante todo su derrotero como lector, lo que se traduce luego en la importancia atribuida por Pivel a este autor dentro de la Colección..., de quien edita varios títulos.

${ }^{46}$ Editado posteriormente en la Hispanic American Historical Review bajo el título "Interview to Juan E. Pivel Devoto" (febrero de 1989).
} 
años, leía y recortaba todos los diarios, y los pocos ahorros que conseguía guardar, los invertía en libros con los que fue conformando lo que más adelante será una de las bibliotecas más importantes de Uruguay. Según consta en una serie de artículos sobre bibliotecas de intelectuales, presentados por Ángel Rama en el semanario Marcha en 1961, su biblioteca contaba con alrededor de treinta mil volúmenes, repartidos en todas las partes imaginables de su casa. La mayor parte era de Historia, como era de esperar.

En 1923, ingresó en la educación secundaria en el IAVA — que en ese entonces dependía de la Universidad - . Justo en aquel año culminaban las obras para la erección del monumento a Artigas en la plaza Independencia, las cuales siguió de cerca. A partir de ese momento, comenzó a estudiar a este prócer gracias a la lectura de La Epopeya de Artigas de Zorrilla de San Martín, libro que le había regalado su madre, quien también le obsequió Historia de la dominación española en el Uruguay de Francisco Bauzá, el historiador que más marcó a Pivel en su vida (Vidaurreta, 2001, p. 24). El día de la inauguración del monumento, el 28 de febrero de 1923, Pivel se encontraba entre los asistentes y escuchó todos los discursos, entre ellos el del propio Zorrilla.

En el IAVA, donde Pivel cursó el secundario, se encontraban los mejores docentes del país. Además, ese liceo contaba con una biblioteca bien nutrida. Según recordaba Pivel, allí comenzó a dedicarse enteramente al estudio de la historia (tanto era su interés, que quedaba libre por faltas en las distintas asignaturas, las que finalmente debía rendir en forma libre; Vidaurreta, 2001, p. 23).

A la hora de ingresar al nivel terciario, su decisión fue continuar con los estudios humanísticos, entre los que se orientó hacia la abogacía, ya que no existía aún la Facultad de Humanidades.

Al no haber una institución que formara en estudios terciaros sobre Historia, los futuros investigadores debían, en su mayoría, hacerse de planes de lecturas, influidos por otras obras de importancia historiográfica o por docentes y demás investigadores amateurs que pudieran sugerir derroteros ya transitados por ellos. En consecuencia, Pivel decidió cursar únicamente las materias que le interesaban dentro de la Facultad de Derecho, y armarse un plan de lecturas, que cumplía a rajatabla, con Bauzá como guía.

Su larga carrera política e intelectual lo llevó a ser director del Museo Histórico Nacional (1940-1982) —en adelante MHN- y a integrar diversas comisiones interesadas en la conservación del patrimonio histórico del Uruguay. Fue gracias Luis Alberto de Herrera que Pivel pudo acceder al puesto de director, luego de la muerte de Daniel Martínez Vigil en 1940. 
El MHN, creado en 1838, fue pensado como una institución que contribuyera a la conformación histórica de la identidad nacional. La llegada de Pivel a dicho recinto decantaba una de las tantas posibilidades que tenía en su horizonte de expectativas. Desde sus redes políticas se le habían ofrecido algunos cargos dentro de la órbita estatal como el de diplomático o incluso el de diputado por el Partido Nacional; sin embargo, ingresar al MHN le permitió posicionarse como una figura dentro del campo historiográfico que intentaba narrar una historia nacional que revisara el relato oficial. Desde allí, Pivel organizó y aumentó la documentación existente; adquirió obras a través de canjes con otras instituciones similares en América; obtuvo ocho nuevos locales -casas de distintos próceres patrios-, y retomó la publicación oficial del Museo denominada la Revista Histórica, a partir de 1942.

Sobre Luis Alberto de Herrera, debemos recordar que no solo fue un caudillo de trascendente actuación política para los blancos - ya que los llevó a ganar su primera elección nacional, para alcanzar el Poder Ejecutivo, luego de 93 años_-, sino que también fue una figura importante para la historiografía nacional. Dueño de una obra conceptualizada como "revisionista", ${ }^{47}$ Herrera se abocó a reconsiderar los distintos tópicos de la Historia oficial uruguaya, correspondientes a una mirada netamente colorada. Dentro de sus puntos más sobresalientes, podemos destacar la formulación de una postura federal, blanca y defensora de la figura del fundador de su partido, el ex presidente Manuel Oribe $-\mathrm{y}$ por ende, la de Juan Manuel de Rosas, aliado natural del presidente depuesto-.

El revisionismo uruguayo tuvo fuerte relación con el argentino, y es por ello que la Guerra Grande fue el tema más reseñado. Entre las obras más importantes de Herrera, encontramos $L a$ tierra charrúa (1901), La Revolución Francesa y Sud América (1910), El Uruguay internacional (1912), La misión Ponsonby (1930), La Paz de 1828 (1940), Orígenes de la Guerra Grande (1941) y Antes y después de la Triple Alianza (1951). Pivel fue continuador de los tópicos planteados por los revisionistas, aunque la historiografía uruguaya no lo considere uno de ellos. ${ }^{48}$

Generalmente, Pivel fue reconocido en el medio cultural uruguayo como el historiador oficial de la nación. Entre sus obras más importantes debemos mencionar Historia de los partidos políticos en el Uruguay (1942), Historia de la República Oriental del Uruguay (1945), Raíces coloniales de la Revolución Oriental (1952), Historia de los partidos y de las ideas políticas en el Uruguay (1956) y Los bancos, 1868-1876 (1976), entre otras.

\footnotetext{
${ }^{47}$ Ver Ribeiro (1991), Rilla (2008) y Soler (1993).

48 Ver Ribeiro (1991), Rilla (2008), Sansón (2006 y 2007) y Soler (1993).
} 
Durante la dictadura cívico-militar (1973-1985), Pivel continuó sus actividades dentro del Estado como director del MHN, editando la Colección ... desde 1973 hasta 1982, cuando fue destituido.

Una vez finalizada la dictadura, fue nombrado presidente del Consejo Directivo Central (Codicen) de la Educación Pública, durante la primera administración de Julio María Sanguinetti como Presidente de la República, entre 1985 y 1990. Ese fue el último cargo público que desempeñó, ya que murió en Montevideo el 11 de febrero de 1997.

\section{El joven Pivel (1930-1940)}

Si bien el título de este segmento parece poco original — porque remite al joven Marx, al joven Hegel, y hasta al joven Quijano, en Uruguay_-, encierra un irónico oxímoron, pues hablar de Pivel supone generalmente hacer referencia al historiador, y la imagen que se repite es la de un hombre con pelo grisáceo, enjuto y ya entrando en la ancianidad ${ }^{49}$.

Sin embargo, existió un joven Pivel que, entre sus veinte y treinta años, se encargó de escribir, investigar y recabar información y documentación, además de gestar sus redes intelectuales, para finalmente llegar a ser director del MHN en 1940.

El corpus documental que hemos empleado, para estudiar al joven Pivel, se centró en el período 1928-1940, entre su egreso del colegio secundario y su nombramiento como director del MHN.

Como dijimos, en sus primeros años Pivel fue muy influido por Francisco Bauzá. La obra que lo marcó, como estudioso de la historia nacional, fue la Historia de la dominación española en el Uruguay, de cuyo prólogo (del propio Bauzá) se valió como guía de sus futuras lecturas historiográficas, ya que en dicha obra se hacía un recorrido crítico sobre los libros de Historia de América y del Río de la Plata previos al suyo, de fines del siglo XIX. Remarquemos: Pivel utilizó la lista que proporcionó Bauzá en su prólogo, como guía para sus propias lecturas (Vidaurreta, 2001), como forma de poseer una base historiográfica en la que apoyarse para sus futuras investigaciones y referencias eruditas.

Si nos acercamos a la «Reseña preliminar» de la Historia de la dominación..., podemos observar el orden dispensado por Bauzá a la bibliografía que consideraba pertinente consultar. Allí estableció distintos niveles: inicialmente, la enumeración de los archivos de cronistas, escritores, viajeros, historiadores y demás autores que abordan el período colonial; luego, la bibliografía jesuítica argentina y brasileña, para cerrar con la uruguaya, que es la que nos interesa considerar aquí.

\footnotetext{
${ }^{49}$ Ver más adelante la imagen del maduro Pivel.
} 
Lo que Bauzá apreciaba como el «mayor tesoro bibliográfico», era la serie documental de la Biblioteca del Comercio del Plata, en cuyas páginas estaban las colecciones de Florencio Varela, Andrés Lamas y Vicente Fidel López (Bauzá, 1965, pp. 63-64). Posteriormente, mencionó otras dos colecciones documentales: los Libros capitulares de Montevideo (en cuatro volúmenes), iniciada por Antonio Mascaró y terminada por Isidoro de María, y el Límite Oriental del territorio de Misiones (en dos volúmenes), donde estaba el Diario de Cabrer, publicado por Melitón González. Para finalizar la lista, Bauzá hizo referencia al Artigas (un volumen) de Clemente Fregeiro. ${ }^{50}$

Con respecto a los libros de historia, Bauzá mencionó a 17 autores, de los cuales seis fueron publicados por la Colección... (tres tuvieron prólogo de Pivel, lo que demuestra el interés y la perseverancia de sus primeras y juveniles lecturas). ${ }^{51}$

Además de lo editado en la Colección... suponemos, como consecuencia de lo manifestado por Pivel (Vidaurreta, 2001), que el resto de los autores leídos probablemente durante su juventud fueron, entre otros, De Pascual, cuyo seudónimo era Adadus Calpi (Historia de la República Oriental del Uruguay) —aunque, según comentaba Bauzá, estaba muy desacreditado entre los americanistas-, Francisco Berra (Bosquejo Histórico de la República Oriental del Uruguay), quien fuera también desautorizado, Antonio N. Pereira (Artigas y Las invasiones inglesas al Río de la Plata); Antonio Díaz (Biografía de Artigas), Juan Maeso (El General Artigas), Domingo Ordoñaña (Fray Bernardo de Guzmán), Gregorio Pérez Gomar (Américo Vespucio), Víctor Arreguine (Historia del Uruguay), Andrés Lamas (Estudio sobre el escudo de armas de Montevideo), Mariano Soler (La América precolombina), y José Figueira (Los primitivos habitantes del Uruguay). ${ }^{52}$

El plan de lecturas que siguió Pivel fue completado con el estudio directo de los documentos disponibles en Uruguay. Por ello, comenzó sus visitas asiduas a diversos repositorios como el AGNU, el Archivo de la Catedral y el Archivo del Estado Mayor del Ejército, donde luego de tantos años de consulta fue alistado como soldado para seguir con sus búsquedas. Desde allí comenzó a formar las redes intelectuales que le permitieron ser un ilustre conocido en el pequeño campo intelectual uruguayo. En consecuencia, y gracias a su interés por la historia, terminó convirtiéndose en docente e investigador.

\footnotetext{
${ }^{50}$ Dentro de esta colección documental sobre Artigas, se extrajo un artículo escrito por Frigeiro, que fue editado en el tomo titulado La independencia nacional (1975), publicado por la Colección... y prologado por Pivel.

${ }^{51}$ Hablamos de Isidoro de María (1957), Montevideo Antiguo; Alejandro Magariños Cervantes (1963), Estudios históricos, políticos y sociales sobre el Río de la Plata; Juan M. de la Sota (1965), Historia del territorio oriental del Uruguay. Los otros autores publicados pero no prologados por Pivel fueron: Carlos María Ramírez (1953), Artigas; Dámaso A. Larrañaga (1965), Selección de escritos, y Francisco Acuña de Figueroa (1978), Diario histórico del sitio de Montevideo.

${ }^{52}$ La lista se encuentra en Bauzá (1965, pp. 64-65).
} 
Luego de sus estudios nóveles, se ocupó de la transcripción de documentación relacionada con la historia nacional y diplomática, preparando las series documentales que posteriormente utilizó como base para sus afirmaciones como encumbrado historiador. En sus primeros años de carrera, abordó el período de formación del nuevo Estado uruguayo (1826-1835), centrándose en sus misiones diplomáticas, debido a su función como investigador del Ministerio de Relaciones Exteriores.

Respecto a sus publicaciones, destacamos tres etapas: la primera tuvo que ver con sus investigaciones nóveles sobre las imprentas; luego, con sus estudios diplomáticos, para finalizar, con su primera investigación de importancia, que lo catapultó como un serio e influyente historiador.

Es necesario señalar que, en sus dos publicaciones iniciales de 1930, se encargó del estudio de la imprenta del Ejército Republicano, de la Provincia Oriental, y de la de San Carlos de Maldonado (las últimas dos, con la ayuda de su amigo y mentor religioso, el jesuita Guillermo Furlong Cardiff ${ }^{53}$, quien complementaría los estudios del lado argentino).

Por ejemplo, en su segundo trabajo, titulado Historia y bibliografía de la Imprenta de la Provincia (1826-1828) y de la Imprenta San Carlos (1930), Pivel ensayó un estado de la cuestión con respecto a lo que se había escrito sobre las imprentas, con foco en los errores que habían cometido los historiadores anteriores, frente a lo cual demostraba su propio conocimiento del campo, y una postura crítica y detallista ante la investigación histórica. Este rasgo fue desarrollado posteriormente por Pivel, quien siempre hizo alarde de su sabiduría histórica, citando obras y documentos in extenso, ${ }^{54}$ además de que, para apoyar su discurso y ser más efectivo en sus valoraciones, criticaba a varios historiadores reconocidos.

La mayor parte de los documentos citados en Historia y bibliografía... eran inéditos, según mencionó Pivel (Vidaurreta, 2001, p. 40). Justamente, este segundo artículo, que parece más acabado que el primero, posee un detalle interesante, ya que Pivel y Furlong asumieron un error en la publicación anterior sobre el mismo tema, editado en Buenos Aires. ${ }^{55}$ Ambos afirmaron que

...al terminar la guerra del Brasil, en el año 1828, la Imprenta del Ejército fue conducida a la Aguada, pasando a ser entonces Imprenta del Estado y

\footnotetext{
${ }^{53}$ Furlong Cardiff (1889-1974) fue un prolifero historiador íntimamente emparentado con la Iglesia Católica, ya que era sacerdote jesuita. Hacia 1930, en una estadía en el Colegio Sagrado Corazón de Montevideo, tuvo contacto con varios historiadores, entre ellos Pivel, con quien trabó amistad y con el que colaboró en sus primeros trabajos historiográficos.

${ }^{54}$ En el caso de Pivel, no es una exageración decir que citaba extensamente documentos o autores. En varios de sus libros lo hacía, a menudo, por más de cinco páginas, generalmente como forma de ilustrar aquello que explicaba o afirmaba.

${ }^{55}$ Es raro que el Pivel más maduro asumiera sus errores. En sus publicaciones posteriores, si bien podía cambiar de parecer, no registraba esos cambios o errores. Veremos algunos ejemplos a lo largo del capítulo.
} 
refundiéndose luego con la Imprenta Republicana, la que hacíamos aparecer como ex imprenta de la provincia. Tal afirmación, fruto de un error lamentable que nos apresuramos a rectificar, es inexacta. La Imprenta del Ejército, una vez firmada la paz y luego conducida a la Aguada, no fue la Imprenta del Estado como decíamos, sino que se denominó Imprenta de la Libertad, la que, instalada en Montevideo, funcionó en esta ciudad por varios años (Pivel y Furlong, 1930, p. 19).

Sin embargo, también se citó una inexactitud cometida por Isidoro de María en Montevideo Antiguo, respecto del nombre de un prensista, José María Rosete, mencionado varias veces por De María pero que, según probara Pivel, no aparecería en ninguna lista de las consultadas. ${ }^{56}$ Posteriormente se transcribieron las tablas del debe y haber de la Imprenta de la provincia, así como los traslados, costos y alquiler de sus distintas piezas. Además, se adjuntaron los contratos de los distintos empleados que trabajaron, señalando sueldos y nombres, manifestando un conocimiento cuantitativo y cualitativo del objeto de estudio. Finalmente, se enumeró aquello que se imprimió y en qué lugar del territorio se hizo, ya que era una imprenta circulante. Respecto a la imprenta de Maldonado, Pivel manifestó que existió pero que, al no haber documentación disponible, no se pudo desarrollar un estudio más detallado.

Estos primeros artículos, producidos por el joven Pivel, ponen en evidencia el esfuerzo de generarse un espacio en el campo intelectual nacional, apelando al mérito propio de un investigador en formación. La acumulación de citas como marca erudita, la falta de interpretación global para con la historia uruguaya y regional, la escasez de reflexiones y los apuntes de detalles menores, sin afirmaciones innovadoras (como en el ejemplo arriba mencionado), evidencian su carácter amateur.

Sin embargo, también podemos advertir que los trabajos iniciales de Pivel presentan un camino que quedó trunco para la historiografía uruguaya, ya que se los puede considerar como antecedentes de la llamada "Historia del libro", dentro de la Historia cultural. Pivel quedó en la primera fase, estudiando las imprentas, sin seguir adelante en su indagación sobre el circuito de comunicación, tal como sería postulado mucho después por Robert Darnton (2010). El posterior derrotero biográfico de Pivel, y su lento pero seguro avance en el campo historiográfico nacional, lo hicieron mantener una línea tradicional, ocupada más por los estudios políticos que por otras formas de historia innovadoras, e incluso de vanguardia para la época. La muerte de Eduardo Acevedo Vázquez y la dirección del MHN, así como el apoyo político del herrerismo, le facilitarían las tareas.

\footnotetext{
${ }^{56}$ Puede consultarse en Pivel y Furlong (1930, nota 16, pp. 16-17).
} 


\section{La historia diplomática}

Luego de sus primeras dos publicaciones como investigador entre 1931 y 1933, Pivel llevó adelante una serie de estudios histórico-diplomáticos, gracias a su ingreso en la Comisión de Límites del Ministerio de Relaciones Exteriores. El interés por este tipo de temas fue, como recordó él mismo en la entrevista realizada por Vidaurreta ya mencionada, enmarcado dentro del problema que representaba en la época la falta de límites geográficos con Argentina y la imprecisión con respecto a Brasil, que recién años más tarde pudo ser resuelta entre los dos países (Vidaurreta, 2001, p. 40).

Los artículos que derivaron de dichas investigaciones fueron editados en el Boletín ${ }^{57}$ del Ministerio de Relaciones Exteriores, que reiniciaba sus publicaciones (segunda época), y en la Revista del Instituto Histórico y Geográfico del Uruguay. Las temáticas se relacionaban con documentación diplomática —misiones de Nicolás Herrera y Francisco Muñoz- y con estudios críticos de algunos documentos — como sobre Fructuoso Rivera y los «Corsarios artiguistas»-

Fue en la primera publicación de su segunda época como investigador, llamada $D e$ nuestra historia diplomática, donde la dirección del Boletín subrayó la presencia del novel investigador:

El «Boletín» ha sido feliz pues pudo confiar esa investigación documental al señor Juan E. Pivel Devoto, que reúne ampliamente todas las condiciones necesarias. A su estudiosa pasión por la papelería y a su notoria capacidad une la consagración de ser autor de libros que, como — entre otros- «La misión de Nicolás Herrera a Río de Janeiro», están construidos con verdadero criterio científico y redactados con severa elegancia (Pivel, 1933a, p. 4).

Esa calidad demostrada como archivista y paleógrafo, así como también sus dotes como investigador, permitieron su designación para desarrollar dicha investigación, como si fuera un mérito destacable entre los demás. Sin embargo, lo que no se dice es que, en este éxito, también jugó un papel importante el buen manejo de las redes intelectuales por parte del propio Pivel.

El futuro director de la Colección... llevó adelante la transcripción de dos documentos para anexionar a la historia diplomática del Uruguay. Si bien las fuentes habían sido editadas, Pivel dijo que «Al proceder [...] a su publicación, lo hacemos como corresponde: respetando fielmente la forma del original, fundamental detalle éste que no ha sido observado por los

\footnotetext{
${ }^{57}$ Según se puede leer en su justificación, la idea del Boletín era editar «documentos inéditos, metódicamente agrupados, de carácter histórico-diplomático, relativos al país. Con ello se tiene el propósito de ir poniendo a disposición de los historiadores y de los historiógrafos, materiales desguazados, extraídos de nuestro disperso acervo documental» (Pivel, 1933a, p. 3).
} 
publicistas antes citados» (1933b, p. 5). Este punto fue insistentemente repetido por Pivel en las distintas instancias de reunión que tuvo con la comisión editora del Archivo Artigas, donde el respeto por el documento era una de sus obsesiones y por lo que se ganó duros enfrentamientos hasta con el propio presidente de la Comisión, Eduardo Acevedo.

En la entrevista realizada por Vidaurreta (2001), Pivel recordó uno de sus primeros trabajos de envergadura, al señalar que, como consecuencia de sus viajes a Río de Janeiro en agosto de 1935, y su posterior ingreso al Instituto Histórico y Geográfico del Uruguay, pudo editar sus investigaciones en la publicación anual de dicha institución. El artículo sobre $E l$ Congreso Cisplatino (1821) (1937) fue, según sus grandilocuentes palabras, «respaldado por una rigurosa contribución documental hasta entonces desconocida» (Vidaurreta, 2001, p. 37). Además, señaló que

... espíritus circunspectos calificaron mi obra de «irreverente». Después de algunos años recién pude apreciar el grado de inconsciencia que entrañaba el rumbo de mis investigaciones, que no respondían a otro objeto que a abrir camino claro a la verdad histórica del Uruguay (Vidaurreta, 2001, p. 37).

Todo acto de memoria supone un ejercicio de resignificación de los acontecimientos a la luz del presente, y sobre todo de la intención de autolegitimación. En este caso, Pivel pretendió resaltar a posteriori, en sus orígenes de investigador, la obra nacional llevada adelante como historiador.

Sin embargo, al analizar detalladamente el artículo referido, podemos contradecir esta mirada homogénea sobre la totalidad de su legado historiográfico.

Inicialmente, el joven Pivel citaba a los historiadores de rigor: durante sus años de formación como investigador, siempre remarcó la importancia que tuvieron estas figuras (Blanco Acevedo, Magariños Cervantes, De María y Bauzá, entre otros) para la Historia de la historiografía nacional. También señalaba a Eduardo Acevedo, quien más adelante sería un intrigante olvido en su reelaboración del canon personal.

A su vez, y llamativamente con respecto al resto de su obra, mencionaba de buena gana a Francisco Berra, quien tendrá oportunidad de ser destronado en varios prólogos de Pivel editados por el Estado — tanto en la Colección... como en el Archivo Artigas-. Así, por ejemplo, en referencia al uso de moños azules en los brazos de los portugueses en el Congreso Cisplatino, en la nota 35 se puede leer: «El DR. FRANCISCO BERRA, con la base del artículo del Argos, que reproducimos bajo el n. ${ }^{\circ}$ 37, séptima parte del presente Repertorio, dice, en su Bosquejo histórico, no siempre bien apreciado, a propósito de las fiestas del 5 de agosto...» 
(Pivel, 1937a, p. 142).$^{58} \mathrm{Si}$ bien parece una minucia, la referencia a Berra como un autor «no siempre bien apreciado», chocaría duramente con la opinión posterior que tuvo el propio Pivel maduro sobre dicha obra y sobre su autor. ${ }^{59}$

Inteligentemente, Pivel actuó como archivista de sí mismo, buscando homogeneidad en el relato de su biografía, tanto política como intelectual. Debemos señalar que al investigador, y en este caso también hablo por mí, se le hace muy difícil encontrar las marchas y contramarchas que tanto Pivel como cualquier otra persona tienen durante su vida. Como observamos, las primeras publicaciones de Pivel tuvieron un factor común que luego se repitió constantemente en su obra madura, con respecto al supuesto apego riguroso al documento. En el artículo señalado, se presentó una selección del repertorio documental vinculado al período de control lusitano (1820-1824), aunque primero Pivel llevó adelante un estudio crítico de dichos documentos, para luego citarlos íntegramente en el apéndice.

Pivel describió los antecedentes del Congreso, e hizo referencia a la gran variedad de documentos consultados, de manera exacta, resaltando parte de lo citado y señalando estrictamente de dónde había sido extraído. El artículo al que hacemos referencia fue acompañado por seis imágenes, pertenecientes a los protagonistas de lo narrado, y por algunas medallas de la época en manos del MHN. En otros casos, en los pies de página, se citaban documentos enteros como forma probatoria, a veces por más de una página, aunque sin estudio crítico. Es, sin dudas, su primer trabajo extenso, con 314 páginas, de las cuales 265 constituyen un apéndice documental, lo que demuestra el enorme peso dado a las fuentes primarias en desmedro de la interpretación.

Además, su estilo de escritura era desprolijo, con oraciones extremadamente largas y poco claras. Por ejemplo, puede leerse que

...mientras la Corte de don Juan VI en los doce años de residencia en Río de Janeiro, había intentado llevar a la práctica —y realizado en parte- el plan del Conde da Barca en el sentido de desarrollar una política que convirtiese a Portugal en gran potencia americana, como medio de compensar el abandono que hicieran de ella en el Congreso de Viena los otros estados europeos, las ideas liberales que se agitaban entonces en Europa habían ido madurando lentamente en la península un movimiento que estalló en 1820 (Pivel, 1937a, pp. 115-116).

Durante todo el artículo, Pivel llevó adelante el relato de los acontecimientos sin ninguna valoración histórica interpretativa, de forma coherente con respecto a su perspectiva

\footnotetext{
${ }^{58}$ Mayúsculas en el original. El destacado es mío.

${ }^{59}$ Este punto será desarrollado con detalle en el Capítulo 7, cuando se analice el modo en que Pivel mantuvo la censura estatal sobre la obra de Berra.
} 
conservadora y acrítica para con la historia. Recién sobre el final, ensayó una serie de reflexiones heurísticas:

Los documentos que forman este libro, han sido reunidos en larga y penosa tarea. Al margen de otras actividades que guardan poca relación con la historia, la búsqueda de los antecedentes que a ella se van incorporando en un devenir sin término, presenta mayores dificultades. El placer de haberlas vencido y la emoción que depara ese peregrinaje por los Archivos - campo yermo en el concepto de muchos- es la única recompensa a que aspiró el autor de estas páginas, que ofrece a los estudiosos y profesores de su país, un manojo de documentos que encontró dispersos. Aun cuando adivine la sonrisa irónica de quienes sostienen desdeñosamente que es esta una tarea inferior de heuristicos y papelistas. Por cuanto siempre ha pensado que, entre nosotros, los estudios formales de historia son, desgraciadamente, casi confidenciales... (Pivel, 1937a, p. 160).

La mejor manera de resaltar las investigaciones, y sobre todo el trabajo con archivos, era explicitar esos elementos en el cierre del artículo. Pivel señaló varias cosas que resultaban interesantes y que dejaban entrever el panorama del campo historiográfico uruguayo. Al inicio citó las dificultades que enfrentaba, para desarrollar una investigación, por culpa de los archivos. El acceso a los mismos no estaba nada aceitado en los años treinta, y el ingreso estaba reservado a unos pocos investigadores con vinculaciones políticas y personales de cuantía. Esos escollos fueron resueltos por el joven Pivel, gracias a sus redes intelectuales.

Por otro lado, defendió su labor esgrimiendo que los estudios «formales» en Historia eran «casi confidenciales», denostando a muchos investigadores sin mencionarlos, para no ganarse enemigos y para dejar un vacío a ser llenado por él mismo, gracias a la legitimidad otorgada por sus propios lectores. Además, Pivel dejó entrever lo pequeño que era el campo historiográfico uruguayo.

Finalmente, una vez que asumió como director del MHN, sus publicaciones tuvieron cambios sustanciales. ${ }^{60}$ Por ejemplo, los temas sobre los que editó estuvieron vinculados a su nueva función en el Estado, ya que Artigas y la independencia de Uruguay comenzaron a ganar importancia en su trabajo, consumiendo sus tiempos de investigador. La variedad de temas dio paso a lo que le interesaba al Estado para afianzarse simbólicamente y construir ciudadanía.

Podría decirse, en función de lo desarrollado hasta aquí, que la llegada de Pivel a la dirección del MHN había tenido que ver con sus «dotes» como investigador. Sin embargo, si nos

\footnotetext{
${ }^{60}$ Sus artículos fueron publicados por la revista de la UTU (Universidad del Trabajo del Uruguay) llamada Voluntad.
} 
detenemos a considerar en las redes intelectuales tejidas durante su juventud, nuestra perspectiva sobre su derrotero biográfico puede modificarse.

\section{El joven Pivel y la formación de sus redes intelectuales (1928-1940)}

El concepto de redes intelectuales ${ }^{61}$ sugiere la relación entre un conjunto de personas que se abocan a la producción y difusión de sus ideas, y que se vinculan entre sí, debido a su actividad intelectual. En este punto, ese concepto puede articularse muy bien con las nociones de "campo intelectual" y de "campo cultural", desarrolladas por Bourdieu (2002).

Hablar de las redes intelectuales de Pivel, antes de ser director del MHN, supone ver el recorrido de un simple estudiante de secundaria con deseos de convertirse en historiador, con sobradas ganas de lograr sus objetivos a través del capital social que podía acumular en un pequeño medio intelectual como el montevideano de los años veinte y treinta.

Debemos destacar que la consideración de sus redes nos hace reparar en varios núcleos intelectuales y de poder bien constituidos, donde lo que buscó Pivel fue ingresar a cada uno de ellos gracias a cierta fama de joven erudito y con un vasto conocimiento de los archivos éditos e inéditos. En este caso, analizaremos cuatro de ellos: el núcleo historiográfico, el políticoadministrativo, el militar y el religioso.

Durante su estadía como estudiante de los cursos secundarios en el IAVA, Pivel tuvo profesores que contaban con ciertos puestos de privilegio en el campo cultural nacional. Uno de esos docentes, Julio Lerena Juanicó (poeta, escritor y docente), fue fundamental para el ingreso de Pivel dentro del campo historiográfico en formación, ya que en 1928 le presentó a Daniel García Acevedo, Gustavo Gallinal, Mario Falcao Espalter, ${ }^{62}$ Pablo Blanco Acevedo, Felipe Ferreiro y Luis Alberto de Herrera (Vidaurreta, 2001, pp. 28-29). También es bueno remarcar que, además de presentarlo en sociedad, el poeta estaba al frente del Archivo de la Catedral de Montevideo, por lo que, en consecuencia, luego de largas horas de consultas, conoció allí a Alfonso Llambías de Azevedo. ${ }^{63}$ Las cercanas relaciones entre el joven estudiante Pivel y Lerena Juanicó también pueden ser rastreadas en la biblioteca personal del historiador. Existen actualmente dos libros dedicados al poeta que sugieren cierta influencia directriz gestada durante los primeros años de su formación intelectual. Al prestarle o regalarle obras a

\footnotetext{
${ }^{61}$ En este capítulo será tomado sobre la base de Devés Valdés (2007).

${ }^{62}$ Merecedor de un tomo dentro de la Colección... llamado El Uruguay entre dos siglos (1983). Cabe destacar que un ejemplar de la obra (Entre dos siglos. El Uruguay alrededor de 1800 impreso en 1922, en la que se basa el editado por el Estado) se encontraba en la biblioteca de Pivel, dedicado por Falcao Espalter (1932), con una dedicatoria en la que se lo llamaba a Pivel «investigador y amigo».

${ }^{63}$ Éste se encargó del prólogo de los dos tomos de Emilio Oribe (1968), Poética y plástica, editados por la Colección...
} 
quien, de alguna manera, era su discípulo, seguramente terminó influyendo en esas lecturas y en otras de las que no tenemos registro. Además, estos libros de Lerena Juanicó estuvieron en la biblioteca piveliana hasta el final de sus días, lo que remarca su influencia y cariño. ${ }^{64}$ Este núcleo de influencia política e intelectual que señalamos, no diferenciado en el Montevideo de los años reseñados, refuerza sus vínculos con la Iglesia Católica, institución a la que estuvo ligado durante toda su vida.

Según la historiografía Pivel era un católico practicante ${ }^{65}$, aunque su hijo lo contradice efusivamente ${ }^{66}$. Gracias a sus vínculos con la Iglesia, llegó a tener como compañero en la Orden Tercera de los franciscanos a Enrique Gamio, quien lo presentó en el liceo Gabriela Mistral, donde comenzó a dictar clases de historia en 1930.

Por otro lado, debemos indicar que el mejor lugar para desarrollar las redes intelectuales, dentro del campo historiográfico, se encontraba en las habituales reuniones realizadas por el Instituto Histórico y Geográfico del Uruguay. A raíz de los vínculos construidos por el joven Pivel dentro de dicha institución, primero pudo ingresar en 1931 como miembro común y, luego, en 1935, se gestó su consolidación como miembro de número, con récord de votos según él mismo recordara (Vidaurreta, 2001, p. 36).

Gracias a su relación con el Instituto, Pivel conoció a Virgilio Sampognaro ${ }^{67}$ dentro del AGNU, en 1928. Por él ingresó a la Comisión de Límites, donde se acercó a la historia diplomática y pudo editar algunos artículos dentro de la Revista del Ministerio de Relaciones Exteriores, que había vuelto a ser editada. Sin embargo, cuando Sampognaro dejó su puesto de canciller del Uruguay por el de embajador en Alemania, en 1934, la Revista dejó de salir. En parte, esto generó el vuelco de Pivel hacia la docencia (Vidaurreta, 2001, pp. 32-34).

De todos los historiadores conocidos por el joven Pivel en 1928, algunos nombres fueron fundamentales para permitirle continuar su rápido ascenso. Primero, García Acevedo lo autorizó a ingresar en los archivos personales de Lucas Obes $^{68}$ y de Julio Herrera y Obes ${ }^{69}$, y le facilitó la consulta de la correspondencia de Nicolás Herrera, lo que le valió varias publicaciones durante su etapa juvenil.

\footnotetext{
${ }^{64}$ Agreguemos que Lerena Juanicó murió en 1938, sin ver la llegada de Pivel a la dirección del MHN.

${ }^{65}$ Ver Rilla (2008), Sansón (2006 y 2007) y Vidaurreta (2001).

${ }^{66}$ Ver Entrevista a Pivel.

${ }^{67}$ Las relaciones vienen de antes. si bien nunca hubo un vínculo directo entre los dos, Sampognaro fue amigo de su padre, y además su hijo fue amigo en la infancia de Pivel.

${ }^{68}$ De origen patricio, Lucas Obes (1782-1838), fue una de las figuras políticas más activas en los años de la transición entre la colonia y la definitiva independencia. Fue Ministro de Gobierno del primer presidente del Uruguay, Fructuoso Rivera el fundador del Partido Colorado, donde fue la figura dominante de la política en aquellos años.

${ }^{69}$ Fue presidente del Uruguay (1890-1894) y figura del civilismo colorado. Descendiente de Lucas Obes integró el patriciado uruguayo.
} 
Además, también tuvo contacto con Felipe Ferreiro (senador por el Partido Nacional, historiador, miembro y presidente del Instituto Histórico), quien fuera más adelante su íntimo amigo, y con quien logró la agregatura en Historia americana para dar clases en la sección femenina del IAVA. Según manifestó Pivel, con Ferreiro discutió sobre la Guerra Grande, y en función de dichas discusiones terminó publicando un libro sobre el conflicto (Vidaurreta, 2001, pp. $42-48) .^{70}$

Gracias a su relación con el político blanco, Pivel viajó por primera vez a Río de Janeiro en 1934, para realizar trabajos relacionados con su función de investigador. Allí se dedicó a la copia de documentos que fueron publicados por la Revista del Instituto, entre 1937 y 1938, y que le valieron los elogios de Ferreiro. Años más tarde, Pivel recordó, en entrevista con Vidaurreta, la definición que el historiador hizo sobre su persona: «un joven sabio que reúne, a preclaras dotes de talento y cultivada ilustración, un entusiasmo abnegado y sin límites por la investigación y el mayor progreso de la Historia» (Vidaurreta, 2001, p. 38). Este recuerdo, muy elogioso, por cierto, es rescatado del olvido por su propio protagonista, a manera de auto-elogio que casualmente pintaba la humildad de Ferreiro, pero también lo «joven» y «sabio» que era considerado por entonces Pivel.

En dicho viaje, y tras el intento de Pivel de ingresar a Itamaratí en busca de documentación sobre la historia del Uruguay, logró, por intermedio del historiador Pablo Blanco Acevedo, acercarse personalmente a su hermano, el embajador uruguayo Juan Carlos Blanco. ${ }^{71}$ Este último hizo los arreglos necesarios para que pudiera tener contacto con documentos alojados en el Ministerio de Relaciones Exteriores en Brasil, sobre todo aquellos pertenecientes al período cisplatino (Vidaurreta, 2001, pp. 34-35), ${ }^{72}$ lo que permitió la configuración de su importante artículo sobre el tema.

Finalmente, podemos entender la indudable significación que Pivel le otorgó a su amistad con Ferreiro, quien era, a su vez, amigo y colaborador de uno de los políticos más importantes del período: Herrera. Fue el caudillo blanco quien, como sabemos, influyó sobre Pivel y lo ayudó a llegar a ser director del MHN. Algo que no fue recordado por el viejo Pivel es que, como forma de agradecimiento post mortem (Ferreiro murió en 1963), él mismo introdujo en la Colección ... un artículo de su antiguo amigo. ${ }^{73}$

\footnotetext{
${ }^{70}$ En 1953 editó, en colaboración con su esposa Alcira Ranieri, La Guerra Grande 1839-1851.

${ }^{71}$ En la biblioteca personal de Pivel, existe un libro que perteneció a Blanco, y otro dedicado por él (Discursos y escritos [1879-1910]), en el que lo señala a Pivel como su «afectuoso amigo» (1949).

${ }^{72} \mathrm{El}$ «arduo» trabajo que le propinaba la consulta de estos archivos terminó con un diagnóstico de anemia, según relató Pivel (Vidaurreta, 2001, p. 35). Ese «recuerdo» (real o imaginario) era rescatado para demostrar el nivel de entrega al trabajo que soportaba su cuerpo.

${ }^{73}$ Fue «La revolución de 1825 y la independencia nacional» en AAVV (1975), La independencia nacional, tomo I.
} 
Otra esfera de influencia en la que Pivel estuvo inmerso fue el Ejército, en donde conoció a un amigo de su padre, el coronel Pedro Onetti. A través de este contacto, llegó al coronel Orosmán Ledesma, quien era Jefe del Archivo del Estado Mayor del Ejército, y a Santiago Abella, quien le presentó al Presidente de la República, Juan Campisteguy, también conocido de su padre. A través de estas relaciones, y por intermedio del jefe del Estado Mayor, el general Francisco Borges, Pivel ingresó como soldado sin sueldo para poder trabajar cómodamente en el Archivo del Ejército uruguayo (Vidaurreta, 2001, pp. 30-32).

Gracias a sus vínculos, durante el año 1937 Pivel obtuvo un puesto como docente en el Instituto de Estudios Superiores, dirigido por Eduardo García de Zúñiga, y al que concurrían habitualmente sus amigos Lerena Juanicó y García Acevedo (Vidaurreta, 2001, pp. 30-32).

También en dicho año, Pivel se encaminó a estudiar en el Archivo del Cabildo de Montevideo, en donde conoció a José Espalter ${ }^{74}$ por intermedio de Herrera. A raíz de dicho acercamiento, Pivel pasó a trabajar en forma rentada en la Cancillería. En junio de 1938, el nuevo Ministro de Relaciones Exteriores, Alberto Guani, lo nombró asesor especial, lo que le permitió ingresar en el Consejo de Ministros, y opinar sobre los distintos temas de la Secretaría en momentos difíciles para la región y para el mundo, ya que se acercaba el inicio de la Segunda Guerra Mundial (Vidaurreta, 2001, pp. 41-42).

El acceso a los archivos tenía doble intención: por un lado, aumentar su bagaje erudito, fomentando el conocimiento positivista clásico, de apego al documento; por otro, conectar con otros investigadores, de intereses afines y que le permitieran darse a conocer y consagrarse en el pequeño campo historiográfico, para capitalizar sus estudios históricos y tener acogida en las pocas publicaciones disponibles. Algo que ya puede observarse, en los primeros pasos del joven Pivel, es su vinculación fluida y multidireccional con las diversas esferas públicas y privadas más o menos relacionadas con el campo historiográfico.

En abril de 1940, murió el director del MHN y ese puesto quedó vacante. Entonces comenzaron los movimientos de redes y de capital social. La figura clave fue Luis Alberto de Herrera: el caudillo del Partido Nacional se conectó con Buenaventura Caviglia y con su hermano Luis, ambos integrantes del Partido Colorado, quienes a su vez conectaron con el presidente Alfredo Baldomir para designar a Pivel como el nuevo director del museo (Vidaurreta, 2001, pp. 41-44).

\footnotetext{
${ }^{74}$ Espalter fue Senador, Diputado y Ministro del Interior y de Relaciones Exteriores por el Partido Colorado.
} 
Claramente, Herrera (quien mantenía contacto directo con Pivel, y a quien le aconsejaba que se dedicara a la Historia, lejos de la política partidaria) pudo observar con buenos ojos la posible llegada de un historiador de su bandería política a puestos hegemónicos dentro del campo historiográfico. Los gestos de Herrera no solo estuvieron motivados por la amistad, sino también por coincidir con la mirada del Partido Nacional respecto de la historia oficial del país; era Pivel quien podía hacerlo realidad.

La victoria del joven Pivel y su pasaje a la vida madura como intelectual, con una posición cada vez más potente en términos de poder cultural, se vio coronada con su gran obra historiográfica. En 1941, la Universidad de la República le otorgó por primera vez el premio "Pablo Blanco Acevedo" a obras históricas. En 1934, durante su viaje a Río de Janeiro, Pivel conoció - gracias a Ferreiro- a Mateo Magariños de Mello, descendiente del historiador Mateo Magariños Cervantes. Magariños se hizo su amigo, y debido al interés por la historia que su padre le había contagiado, leyó los apuntes de las clases dictadas por Pivel para los cursos de 1936 a $1940 .{ }^{75}$ A partir de estas anotaciones, armó una versión mecanografiada que, luego de algunos ajustes, fue presentada por Pivel, para el concurso, con el seudónimo de "Rojo y Negro”. Como recordó el mismo Pivel, haciendo ver lo pequeño del campo historiográfico, «no era difícil suponer quién podía ser el autor, habida cuenta de la notoriedad del curso dictado en 1939» (Vidaurreta, 2001, p. 46). El tribunal del concurso estuvo integrado por el Rector de la Universidad, José Pedro Varela Acevedo, y por Rafael Schiaffino, ${ }^{76}$ Eduardo Acevedo, Felipe Ferreiro y Ariosto González. Finalmente, en noviembre de 1941, se le otorgó el premio al libro de Pivel titulado Historia de los partidos políticos en el Uruguay (Vidaurreta, 2001, p. 47).

En diciembre de 1941, se realizó una cena homenaje, planificada por sus colegas y amigos, en cuya ocasión concurrieron algunas personalidades políticas y miembros del jurado. La presencia de esas figuras, en esa instancia de consagración, demuestran lo bien tejidas que estaban sus redes por esos años. Allí se encontraban su padre, Herrera, Eustaquio Tomé ${ }^{77}$, Luis Caviglia y Schiaffino ${ }^{78}$.

Con una obra en la que asentar su figura historiográfica, y con un puesto dentro de la administración estatal y de defensa del patrimonio histórico nacional, ésta fue la hora de un Pivel más maduro y consagrado.

\footnotetext{
${ }^{75}$ Los apuntes habían sido tomados por Alcira Ranieri, alumna y luego futura esposa de Pivel, además de coautora del libro.

${ }^{76}$ Más adelante, la obra de Schiaffino será editada por la Revista Histórica de Pivel, realizando tres publicaciones suyas en dos años: «Política colonial. Incidencias entre don Pedro de Cevallos y don José Joaquín de Viana» (1954, v. 21), y «Guaranismos. Ensayo etiológico», en dos entregas (1956, vols. 25 y 26).

${ }^{77}$ Tomé fue colaborador de Pivel en la Colección... y en la Revista Histórica.

${ }^{78}$ Quien se excusó por enfermedad fue Buenaventura Caviglia (Vidaurreta, 2001, p. 48).
} 


\section{Pivel maduro: historiador y funcionario estatal (1940-1982)}

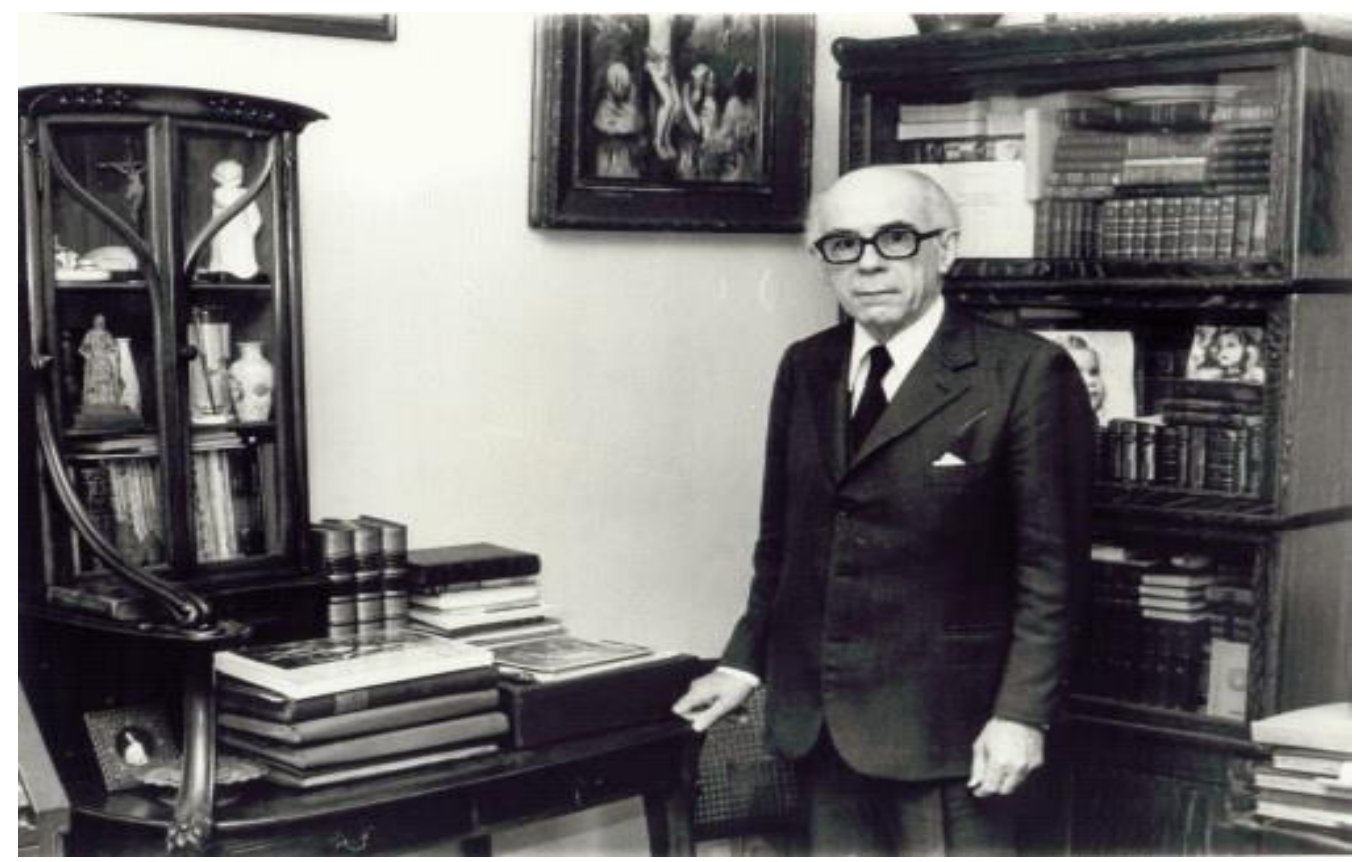

Pivel Devoto en su casa (s/d).

En la imagen precedente vemos a Pivel. Mirada a la cámara, músculos de la cara en descanso, no hay sonrisa sino seriedad, los lentes que luce son de pasta color negro. Traje oscuro a medida con un botón prendido según marcan las reglas del buen vestir. Está parado con las manos hacia abajo; con la derecha toca la punta de un mueble lleno de libros.

En la foto destacan algunas cosas que, de alguna manera, caracterizan quién era y qué quería representar la figura protagonista. Lo que domina el paisaje son los libros, que en su mayoría parecen pertenecer a algunos tipos de colecciones ya que responden al mismo diseño en sus lomos. Los hay de varios tamaños y puestos en diversas formas: parados, acostados, apretados. Además hay recortes de diario encuadernados y demás documentos sobre la mesa. Evidenciamos que es su casa, ya que entre los diversos tomos hay fotos que parecen ser familiares $^{79}$. También hay una imagen que se repite, la crucifixión de cristo, en un cuadro al fondo y en un pequeño objeto dentro de la vitrina que está junto a una estatua del niño Jesús. Pivel quería representarse como un ferviente católico ${ }^{80}$, además de estar vinculado a la Iglesia

\footnotetext{
${ }^{79}$ Fue confirmado por su hijo. Véase, Entrevista a Pivel

${ }^{80}$ En sintonía con el Cristo que invade la escena, su hijo sintetiza que: «... mi padre no era católico para nada. No era católico ni de ninguna religión. Lo que pasa es que respetaba, tenía un aspecto conservador, respetaba lo instituido, la Iglesia Católica con su valor de (...) horma de la sociedad. Respetaba la jerarquía católica» (Véase, Entrevista a Pivel).
} 
Católica como se puede ver en sus redes intelectuales ${ }^{81}$ y por su conocido contacto con el herrerismo nacionalista - el Partido Nacional siempre estuvo emparentado con la Iglesia—.

Esta es la foto que se repite cuando hablamos de Pivel, una rápida búsqueda en internet la ubica en innumerables documentos oficiales y semblanzas. Es un hombre maduro que imprime seriedad; es la imagen de un historiador decimonónico; es un administrador estatal; es editor, y es nuestro protagonista.

A mitad del siglo XX, tener treinta años ya era sinónimo de madurez. Si además le agregamos un puesto de trascendencia administrativa oficial, que pretendía cierta rigidez en su actuación pública, no estaríamos equivocados al esbozar que simbólicamente el joven Pivel "muere" cuando es nombrado director del MHN, ya que desde su primer puesto de poder va a iniciar su carrera como historiador oficial del Estado.

Su obra historiográfica no solo está condensada en las publicaciones librescas: muchos artículos en Marcha y varios prólogos de la Colección... también deberían agregarse, ya que forman parte de su tarea de difusión historiográfica dedicada a otro tipo de público, no tan acostumbrado a comparar libros de historia.

Centrándonos en su papel como historiador, un modo de medir su impacto consiste en analizar la vigencia de su discurso más allá de los límites cronológicos de su actuación pública. Sus estudios abarcadores sobre la historia uruguaya del siglo XIX se mantienen sin grandes cambios. Si bien hubo investigaciones que pusieron en duda muchas de las afirmaciones pivelianas, no contamos con una mirada unificadora que revea sus dos grandes unidades de análisis: la nación y los partidos políticos. Tal como recuerda Rilla,

\begin{abstract}
Pivel es el fundador de la historia política moderna en el Uruguay. Armó una narración matriz y por largo tiempo persuasiva que tuvo a los partidos en el centro de la escena, pero que no quiso traspasar la frontera cronológica -política- que separa al siglo XIX del XX. La reconstrucción piveliana es de la política y de las ideas (la política concebida como lucha de ideas encarnadas en partidos); mantiene vigencia si se piensa que no ha sido hasta ahora mayormente contestada, en su terreno (2008, pp. 186-187).
\end{abstract}

En este punto, creemos que Pivel corre con cierta ventaja: luego de la dictadura, y con el posterior asentamiento del régimen democrático, durante los años noventa, la historiografía

\footnotetext{
${ }^{81}$ En un libro de su biblioteca privada se puede leer una dedicatoria que le firmara Arturo E. Xalambrí que consideraba a Pivel: "Su amigo y admirador en Cristo" (1946). Xalambrí estuvo fuertemente vinculado a la Iglesia Católica ya que trabajó en varias de sus instituciones como el diario El Bien Público, siendo bibliotecario de centros católicos o como Gerente en la sociedad médica Círculo Católico de Obreros. Fue un conocido cervantista; coleccionó diversos ejemplares del Quijote que hoy custodia la Universidad de Montevideo de directa vinculación con el Opus Dei, la misma institución en donde se encuentra la biblioteca privada de Pivel.
} 
uruguaya estuvo concentrada en estudios relativos a la segunda mitad del siglo XX. La explosión de las historias de la última dictadura, de las izquierdas en general y de la guerrilla tupamara en particular - sobre todo influidas por la victoria del Encuentro Progresista-Frente Amplio en 2004-, provocaron el «olvido» del siglo XIX. La investigación académica se ha centrado también en otras perspectivas historiográficas, dejando de lado la historia política, y es gracias a ello que, como dice Rilla (2008), la visión piveliana no ha sido en general ni contestada ni refutada.

Existen actualmente diversas historias del Uruguay que mantienen muchos de los postulados historiográficos de Pivel. ${ }^{82}$ Esto es consecuencia de su método de trabajo como historiador, donde

\begin{abstract}
... esbozó categorías, modificó la percepción de ciertos temas del pasado nacional y utilizó nuevas fuentes o de manera nueva fuentes ya conocidas, en términos que los historiadores profesionales, formados en la universidad, hubieron de retomar (controvertir, profundizar, modificar), nunca ignorar o desdeñar. Las 'desconfianzas' que Pivel Devoto alimentó respecto de las reflexiones teórico-metodológicas sobre la disciplina, fueron en los historiadores universitarios el cauce privilegiado de una mirada crítica a los aportes de aquél, tanto para religar esfuerzos de indagación como para despejar desde opuestas atalayas el campo de futuras experiencias (Zubillaga, 2002, p. 185).
\end{abstract}

Evadir a Pivel se convirtió en algo imposible para todo nuevo historiador que quisiera trabajar la historia del Uruguay y, sobre todo, su historia política. Tanto es así que, en algunas divisiones historiográficas llevadas adelante respecto a la Guerra Grande, siguen utilizándose los períodos y los bandos del modo en que los planteó Pivel. Es más: en las interpretaciones del conflicto, se ha inclinado la balanza hacia una mirada más cercana al Partido Nacional.

La historiadora Ana Ribeiro, en su libro Historia e historiadores nacionales, luego de un recorrido extenso sobre toda la historia de la historiografía del Uruguay, termina por preguntarse:

\begin{abstract}
¿Cómo calificar a este gigante de la historiografía nacional? Ha sido considerado revisionista por su vinculación con Herrera y sus posiciones, por ese replanteo con el que iluminó áreas y conexiones casuales. Pero su rigor documental no es característico de esta corriente. Su figura [...] estigmatiza
\end{abstract}

\footnotetext{
${ }^{82}$ Podemos mencionar las colecciones más conocidas y con mayor tiraje, como la Historia uruguaya, publicada por Ediciones de la Banda Oriental, dividida en 12 tomos (con la participación de 15 historiadores), o la llamada Crónica general del Uruguay, desarrollada en siete volúmenes (cuyos autores fueron Washington Reyes Abadie, Andrés Vázquez Romero y Tabaré Melogno) o, más recientemente, la publicada por la editorial Planeta y el diario El País, titulada Orientales. Una historia política del Uruguay (dividida en cinco tomos), por parte de Lincoln Maiztegui Casas.
} 
los últimos cincuenta años; eso sí es indiscutible y va más allá de rótulos» (Riberio, 1991, p. 39).

Si bien la figura historiográfica de Pivel fue hegemonizante durante los años estudiados, debemos comprender de qué manera pudo gestar y dominar el campo historiográfico desde su primer momento.

\section{La "identidad nacional piveliana" dentro de la lucha historiográfica}

Para ingresar en lo que denominaremos la "identidad nacional piveliana", debemos estudiar la constitución y la lucha entre las dos comunidades historiográficas que surgieron durante los años cuarenta, a consecuencia de la fundación de la Facultad de Humanidades en 1945, y del IPA en 1949. Gracias a sus enraizadas redes intelectuales y a los favores estatales, el discurso piveliano —que contó también con ventaja cronológica ${ }^{83}$ — se constituyó en hegemónico desde el MHN y la Revista Histórica, acercándose al IPA y distanciándose de la FHCE.

Evidentemente, su intervención puso en evidencia - $-\mathrm{y}$ quizás agudizó- una confrontación ideológica entre ambas comunidades historiográficas. Pivel y su grupo de colaboradores de derecha - conservadores del statu quo y de marcadas posturas anti-anaquistas y anti-comunistas - estuvo integrado por herreristas y aliados al terrismo. ${ }^{84}$ Muchos de ellos eran católicos y simpatizantes del alzamiento nacionalista español de 1936, además de partidarios de la neutralidad durante la Segunda Guerra Mundial. En oposición, los jóvenes incorporados a la FHCE eran nacionalistas independientes, antiterristas, partidarios de la República Española y aliadófilos: por ende, mayoritariamente de izquierda (Zubillaga, 1996).

Los enfrentamientos se fueron afianzando, con consecuencias en los diversos proyectos culturales e historiográficos estatales. Por ejemplo, hacia 1952, los núcleos mencionados, sumando al batllismo oficialista de Batlle Berres — con las mismas características que los integrantes de la Facultad-, tuvieron un nuevo enfrentamiento que dejó mermado el presupuesto de la Comisión Nacional del Archivo Artigas. ${ }^{85}$

Respecto de los años sesenta, Zubillaga (2002) logró entrever una variación en las reglas de juego entre el conocimiento histórico y el poder político, debida a la consolidación del campo histórico académico, luego del egreso de las primeras generaciones de historiadores formados por la Universidad. Cuando la Historia, como disciplina, dejó de ser un objeto de legitimación

\footnotetext{
${ }^{83}$ Repetimos: Pivel fue director del MHN desde 1940; reinició la Revista histórica en 1942, y publicó sus obras historiográficas fundamentales entre 1942 y 1945, todo antes de la fundación de la FHCE y del IPA.

${ }^{84}$ Sobre Gabriel Terra, ver Caetano y Rilla, 1999; Frega y otros, 1999, y Nahum, 2001.

${ }^{85} \mathrm{Las}$ inversiones en el Archivo se reiniciaron luego de la victoria del Partido Nacional en las elecciones de 1958.
} 
nacional, los enfrentamientos entre las diversas escuelas presentaron rasgos de confrontación marginales.

Claro que, según Zubillaga,

... hubo en el país solo historiadores del sistema, no registrándose el surgimiento de una vertiente historiográfica alternativa ni entre los elementos «marginados» de la cultura oficial, que nutrieron la bohemia novencentista, ni entre los vanguardistas de las décadas siguientes (incluida la mentada generación del 45). En todo caso, quienes fungieron como disfuncionales a los intereses inmediatos del sistema político, desde posturas revisionistas, fueron la contracara necesaria del sistema mismo: lejos de ponerlo en entredicho, en sus esencias, operaron como intérpretes de un descontento severo, que no apelaba al trastocamiento radical de los supuestos políticos vigentes. La trayectoria historiográfica de Pivel Devoto puede marcar con claridad esta tensión: vinculando al revisionismo nacionalista, logró con una tenacidad inusitada, que algunos elementos de su operación histórica revirtieran las más groseras formulaciones del exclusivismo partidario, pero terminó postulando y ejerciendo un eclecticismo disciplinario que se alejó de las posturas revisionistas, para instaurar una visión componedora de sólida implantación en el espacio estatal y de inequívoca contestación al cambio social (2002, p. 72).

En función de las características propias del campo historiográfico uruguayo, y de su incapacidad de formular fuertes discursos históricos marginados del sistema, Pivel pudo mantener la hegemonía gracias a su prestigio académico, formado sobre la base de la transformación de sus posturas como oficiales y políticamente correctas. Es por ello que, cuando hablamos de nación, tomando como referencia el relato histórico formulado desde el Estado durante los años estudiados, estamos hablando de lo que podríamos definir como la "identidad nacional piveliana".

Dentro de su comunidad historiográfica, constituida y afianzada largamente, Pivel consideraba necesario combatir el desconocimiento ciudadano respecto del pasado nacional. Además, según su diagnóstico, había que forjar la conciencia nacional, cuyo sujeto serían los partidos políticos tradicionales, misión a la que se abocó durante toda su carrera historiográfica.

Luego de la llegada de Pivel al cargo de director del MHN, «se generaron las condiciones para una rigurosa labor heurística de signo oficial. Pivel Devoto fue el principal exponente de esta labor y, seguramente, quien la emprendió con más clara percepción de su finalidad», dice Zubillaga (2002, p. 48). Debemos señalar que el autor de la anterior cita es el actual Director del Departamento de Historiología en la Facultad de Humanidades de la Universidad de la República, además de haber sido dos veces Decano (1989-1997) de la misma casa de estudios, y docente durante la década del setenta de Teoría y Metodología de la Historia (IPA). Como 
dijimos, dentro del campo historiográfico, el enfrentamiento entre el IPA y Humanidades tiene su origen en los años de sus respectivas fundaciones. No hay que desestimar que cuando Zubillaga comenta el trabajo historiográfico de Pivel, podemos observar que los viejos enfrentamientos continúan postmortem, no solo entre instituciones educativas y terciarias, sino también entre personalidades -Zubillaga hace patente en sus clases de la animadversión que siente por Pivel.

La "identidad nacional piveliana" cumplió su función de consolidar el papel del Estado, entendido como expresión política de la nación. Para poner un ejemplo, la creación del Archivo Artigas (1944) respondió al contexto de la Segunda Guerra Mundial, donde la nación se sentía en peligro ${ }^{86}$ En función de ello, la concepción nacionalista defendida por el núcleo piveliano pretendía, en una de sus funciones, eliminar las diferencias sociales partidarias a través de una definición homogénea y amalgamadora de los partidos políticos.

La identidad nacional fue el tema que más le interesó a Pivel. Fue el punto en el que confluyeron sus múltiples funciones como administrador estatal. La nación ${ }^{87}$ fue por lo que vivió en actitud militante durante toda su existencia.

La idea de Pivel era reafirmar, con su tarea historiográfica, la base empírica documental respecto del origen del Uruguay y, para ello, debía forjar una conciencia nacional. Desde su actividad dentro del Estado le sería mucho más fácil encarar ese proyecto. El derrotero de su propia vida lo fue poniendo en lugares privilegiados para llevarlo adelante. Quiso tomar la posta nacional con una impronta supuestamente veraz que solo la Historia positivista como disciplina podía otorgar. La clase política aprovechó a un historiador con filiación blanca, pero con el suficiente tinte colorado en su visión del pasado, como para establecer un relato rosado y conveniente para todos.

En una de las entrevistas brindadas a Vidaurreta, Pivel afirmó, como forma de justificar su posterior actividad, que

\footnotetext{
...muy temprano me convencí [de] que el país tenía que buscar su identidad nacional en la Historia, en sus raíces, en la tradición, en los documentos y en todos los valores representativos del pasado y a ello me apliqué, no con la mentalidad de un anticuario o coleccionista; sí, con inquietud sobre el presente, en el que no podía rehuir mis deberes en todos los órdenes, a través de la militancia cívica y de la información más directa que podía alcanzar sobre los problemas nacionales (Vidaurreta, 2001, pp. 38-39).
}

\footnotetext{
${ }^{86}$ Ver: Nahum (2003), Frega y otros (2008).

${ }^{87}$ Para definir nación, apelamos aquí a las reflexiones de Anderson (2011) y Bhabha (2010).
} 
Sin embargo, Sansón recuerda que «Pivel se transformó en una especie de 'sumo sacerdote de la nación', consagrado a glorificar la patria y sus héroes» (2011, p. 131). A la luz de su tarea historiográfica, más que el sacerdote mencionado, creemos que Pivel fue un apóstol encargado de redactar el evangelio nacional, ya que

... fue un portavoz del sociolecto encrático y su interpretación del rol de los partidos tradicionales en el siglo XIX era funcional al mismo. Creó una historia conciliadora, correlato necesario de la conciliación partidocrática ensayada en su tiempo [...]. Por encima de los errores de ambos bandos postula y destaca un sentimiento común e inconsciente que los unía: el amor a la patria (Sansón, 2001-2002, p. 19).

A su vez, la historiografía nacional de Pivel no fue la misma que vivió el Uruguay durante el siglo XIX, tratando de superar los inconvenientes de los enfrentamientos regionales e internos pues, como bien resume Zubillaga,

... el aporte sustantivo de Pivel Devoto a la renovación historiográfica consistió en dotar de una nueva densidad conceptual al nacionalismo. A diferencia de la actitud nacionalista «estática» o «convalidadora», de la que hiciera gala la historiografía tradicional, Pivel Devoto postuló un nacionalismo «activo», «vivificador», operando como brújula del accionar colectivo (2002, p. 187).

Resaltar los sentimientos nacionales permitía cumplir con el deseo de consolidar el papel unificador del Estado, entendido como expresión política de la nación. Una de sus tareas fue llevar a cabo la Colección..., que buscó ser la amalgama cultural, literaria e histórica de Uruguay. Además, la otra parte del proyecto unificador se completaba, como ya dijimos, con la creación del Archivo Artigas.

La unificación nacional también estaba relacionada con la eliminación de las diferencias partidarias, pues

... la propuesta historiográfica resultaba [...] funcional al régimen político que en 1951 había instaurado, con el apoyo entusiasta del sector mayoritario del Partido Nacional al que respondía políticamente Pivel Devoto, el sistema colegiado integral en el Poder Ejecutivo, haciendo realidad la iniciativa de Batlle y Ordóñez, de ardua tramitación a lo largo de cuatro décadas (Zubillaga, 2002, p. 58).

Como sabemos, Pivel formó parte de ese gobierno de conciliación, integrando las diversas comisiones oficiales sobre temas históricos y culturales. Finalmente, luego de la victoria del Partido Nacional, desde su puesto como Ministro de Instrucción Pública y Seguridad Social 
(ejercido entre 1963 y 1967), pudo conseguir recursos para publicar la mayor parte de la Colección... y terminar de afianzar su discurso nacional, gracias a la influencia directriz que ejerció.

Su posición dentro de la administración estatal pareció estar siempre bajo un manto neutro, amparado en la procura de la unificación nacional, dejando de lado los sentimientos de su propio partido que nunca ocultó y que, sin embargo, según quiso demostrar, no le pesó para hacerse cargo de las diversas tareas encomendadas. En este sentido, podemos agregar que

\begin{abstract}
... la gestión cumplida por Pivel Devoto en el Museo Histórico Nacional constituyó, probablemente, el más nítido ejemplo de estatización del saber sobre el pasado. Convencido de la necesidad de fortalecer el papel del Estado en la reafirmación de una conciencia histórica de la sociedad, Pivel Devoto apeló a múltiples resortes burocráticos, conocedor al máximo de los complejos mecanismos de funcionamiento de administración y de las «virtudes» de la permanencia. Vio pasar ministros de la más variada extracción políticopartidaria y de las más diversas capacidades; a todos asesoró, con todos discutió, podría afirmarse que a todos convenció o «venció» en beneficio de sus empeños realizadores. Historiador del Estado y desde el Estado, Pivel Devoto ejerció su indiscutido «poder» cultural — que se extendió en distintos momentos hacia la Comisión Nacional del «Archivo Artigas» y el Archivo General de la Nación - en tensión hacia la idea de «reconciliar la nación», legitimando el papel de los partidos tradicionales e instituyendo una visión criolla, abroquelada en un estilo que creyó insustituible para la evolución del país (Zubillaga, 2002, pp. 114-115).
\end{abstract}

La nación piveliana estuvo asentada en sus bases historiográficas. Sin embargo, la obra de Pivel no era únicamente historiográfica. Sus trabajos como prologuista y editor fueron para el proyecto nacional, tanto o más importantes que sus libros de historia. Todos juntos formaron un discurso hegemonizante oficial, difícil de ser deconstruido en los momentos en que circulaba por (y funcionaba en favor de) la maquinaria estatal.

Su tarea de prologuista oficial comenzó unos cuantos años después de su aparición en el campo historiográfico, pero fue ejercida de manera homogénea, coherente con su discurso de historiador nacional. En este caso, el mejor escenario para desarrollar su discurso fue la Colección..., un ámbito al que no podía estar ajeno.

\title{
Pivel prologuista oficial de la Colección... (1957-1981)
}

Luego de la muerte de Eduardo Acevedo en 1948, el Estado se quedó sin historiador oficial, y su ausencia tuvo que ser subsanada. Consideramos que, en función del discurso historiográfico que ya caracterizamos y del monopolio ejercido en las comisiones y en las representaciones 
culturales estatales, fue Pivel quien lo sustituyó. La posición hegemónica dentro del campo historiográfico ya había sido asumida, y la lucha dentro del campo cultural e intelectual estaba planteada.

Con la comisión editora de la Colección... funcionando, aunque controlada por los colorados, Pivel hizo su primera aparición, como prologuista, en 1957.88 Tomar los prólogos de la Colección..., como insumo para estudiar cuál era la dirección pretendida desde las políticas editoriales estatales, resulta esencial para comprender las bases sobre las que se eligió asentar la justificación histórico-literaria de la nación. En su triple papel de integrante de la comisión, prologuista e historiador, Pivel fue el mejor para hacerse cargo de abordar, con su discurso erudito, las diferentes obras que, editadas por el Estado, debían transformarse en canónicas para el público lector al que se dirigían.

Doce fueron los prólogos que redactó Pivel en su estancia como colaborador y autoridad de la Colección..., y sumaron unas 1143 páginas en las siguientes obras: Isidoro de María (1957), Montevideo Antiguo; José María Reyes (1960), Descripción geográfica del territorio de la República Oriental del Uruguay; Alejandro Magariños Cervantes (1963), Estudios históricos, políticos y sociales sobre el Río de la Plata; Juan Zorrilla de San Martín (1963), La epopeya de Artigas; Juan M. de la Sota (1965), Historia del territorio oriental del Uruguay; Francisco Bauzá (1965), Historia de la dominación española en el Uruguay; Manuel Herrera y Obes y Bernardo Prudencio Berro (1966), El caudillismo y la revolución americana. Polémica; Bernardo Prudencio Berro (1966), Escritos selectos; César Díaz (1968), Memorias; Francisco Bauzá (1972), Estudios sociales y rconómicos; AA. VV. (1975), La independencia nacional, y Luciano Lira (1981), El Parnaso Oriental o Guirnalda Poética de la República Uruguaya.

En los primeros estudios que realizó, estableció una marca distintiva a nivel discursivo sobre cómo debían ser los prólogos de la Colección..., e hizo respetar ese estilo mientras dirigió esta biblioteca. La fórmula debía contar con algunos ingredientes básicos, a saber: datos biográficos del autor —o autores—- fuentes en las que se basó el autor para diagramar el texto, historicidad de la obra - tanto su primera edición como aspectos relacionados con la financiación o cambios formales en ediciones posteriores-, reseña de lo que se publicaba en el tomo prologado y, finalmente, la justificación e importancia de lo impreso para la identidad nacional cultural uruguaya.

Se puede constatar que la inmensa mayoría de los prólogos de obras historiográficas publicadas por el Estado fueron hechas por Pivel, ya que era él quien generalmente se encargaba

\footnotetext{
${ }^{88}$ Para un análisis de estos prólogos ver el capítulo 5 de esta Tesis.
} 
de seleccionar los títulos a editar. Le siguieron en las preferencias (con dos prólogos cada uno) Eustaquio Tomé ${ }^{89}$ y Raúl Montero Bustamente..$^{90}$ Creemos que no hacerse cargo del prólogo respondió a su falta de interés y de coincidencia de criterio con el título a ser editado. Si bien, como observamos, la Colección... fue prácticamente un proyecto intelectual llevado adelante por Pivel, los políticos de las diferentes épocas se animaban a pedir la edición de obras a través de cartas dirigidas directamente a la Comisión. Las veces en que se les hizo caso -como con Las Instrucciones del año XIII de Héctor Miranda [1964] a pedido del consejero de Estado Martín Etchegoyen- no contaron con los prólogos pivelianos. ${ }^{91}$

Podríamos dividir los prólogos de Pivel ${ }^{92}$ en tres períodos. En primer término, aquellos ofrecidos en los años cincuenta a instancias de la Comisión editora (dos: a Reyes en 1953 y a De María en 1957); luego, los hechos durante su estancia como Ministro entre 1963 y 1967 (seis: Magariños Cervantes y Zorrilla en 1963; Bauzá y de la Sota en 1965, y dos tomos sobre Berro en 1966), que suponen la mayoría fundamental y esencial no solo de su obra como prologuista, sino también de la base historiográfica de la Colección..., y, finalmente, los llevados adelante durante el período 1968-1982, en los años del autoritarismo estatal (cuatro: Díaz en 1968, Bauzá en 1972, una recopilación de artículos en 1975 y Lira en 1981) ${ }^{93}$.

\section{Pivel hegemónico: editor en jefe (1959-1982)}

Figura fundamental en un proyecto editorial, el editor habitualmente se encarga de celebrar el contrato con los autores, de corregir las hojas de prueba para decidir la impresión, de establecer alianzas con libreros y librerías, de poner en circulación el libro con el apoyo de los distribuidores, de negociar con autoridades políticas, de favorecer la publicidad, y de administrar las finanzas, entre otras tareas (Darnton, 2010, pp. 135-136). Delgado y Espósito insisten en señalar en igual dirección, que como agente del campo intelectual, el editor

...define las características de los productos impresos según su gusto y los intereses del nuevo público; dispone la edición de libros como bienes

\footnotetext{
${ }^{89}$ Colaborador y amigo de Pivel, como vimos en el apartado anterior.

${ }^{90}$ Prólogos agregados en los volúmenes de manera póstuma, uno de ellos de 1923 (tomo 152) y el otro de 1936 (tomo 149).

${ }^{91} \mathrm{AGNU}$, Carta de Martín Etchegoyen a la Comisión Editora, Archivo Pivel Devoto, Caja 128, carp. 407, f. 114.

${ }^{92}$ Como dijimos, fueron 12 volúmenes, que sumaron 1143 páginas. Si bien el promedio resulta bastante alto (95 páginas), existieron dos obras que alejan el promedio real de la tarea de prologuista de Pivel: son los tomos dedicados a Bauzá (un prólogo de 679 páginas y otro de 154). Si las quitáramos de la lista, el promedio pasaría a las 31 páginas, una cifra más cercana a la mayoría de los prólogos realizados por él.

${ }^{93}$ ¿Por qué tres períodos? En el primer caso, los prólogos no fueron elegidos por Pivel, sino más bien, adjudicados por la Comisión y hechos por el historiador en su condición de funcionario estatal. Sin embargo, en su segundo período, con un Pivel ya hegemónico y al frente del Ministerio de Instrucción Pública, nuestro protagonista pudo elegir qué prólogos realizar. Finalmente, volvemos al punto inicial, al ver los estudios preliminares encomendados por los gobernantes colorados de turno y llevados adelante por un Pivel funcionario estatal.
} 
culturales organizados en series y colecciones que funcionan como verdaderas guías de lecturas; orienta su intervención hacia el mercado y plantea y estimula líneas de producción literaria contribuyendo a su consolidación como profesión remunerada. Pero al mismo tiempo su labor implica un cúmulo de funciones vinculadas con la profética política y cultural en una sociedad de masas (Delgado y Espósito, 2014, p. 67).

Como ya dijimos, en el caso de la Colección... no existía una única figura de editor, ya que las decisiones las tomaba una comisión; pero según podemos observar en los registros oficiales, la mayor parte de las resoluciones eran firmadas por la misma persona, a veces como jefe editor — cuando Pivel fue Ministro-, y otras como vicepresidente de la comisión — cuando solo fue director del MHN-. Por ende, claramente hablamos de un Pivel hegemónico.

Si bien la figura del editor posee muchas atribuciones, cuando recae en alguien como Pivel, encarna muchas más. Hacia 1959, con la llegada del Partido Nacional al poder, los cambios no solo fueron políticos y económicos ${ }^{94}$ sino también culturales.

Las distintas comisiones de proyectos culturales, heredadas de los gobiernos colorados, pasaron por primera vez a manos de los blancos. Como representante del Partido Nacional dentro de la Colección..., y como director del MHN, Pivel comenzó a tener más injerencia en las decisiones, ya que contaba con el respaldo total del gobierno y de la mayoría legislativa. Esa escalada de poder dentro de la comisión tuvo su época dorada durante su estancia en el Ministerio de Instrucción Pública, entre 1963 y 1967, cuando pasó a dirigir legalmente la Colección...

Recordemos que el joven Pivel, para poder ganarse la vida materialmente, se encargaba de la tarea de corregir las pruebas (Vidaurreta, 2001), lo que ya lo emparentaba con el trabajo que emprendió como editor años más tarde. Múltiples copias de libros que fueron editados pueden encontrarse en el AGNU con las anotaciones y correcciones de Pivel. La obsesión porque todo saliera bien lo llevó a detenerse en los mínimos detalles y a delegar mucho menos de lo que un Ministro debía. El archivo que el propio Pivel armó sobre él, y que se puede consultar en el AGNU, busca poner en evidencia — probablemente de forma deliberada - el infatigable trabajo que hizo, aunque lo cierto es que los documentos abundan y la calidad de las ediciones sin erratas así lo testimonian.

En su tarea de editor, no solo se abocó a la corrección de las copias enviadas para las imprentas: también estuvo presente en la selección de autores, obras, prologuistas y colaboradores, asumiendo el papel de censor. ${ }^{95}$

\footnotetext{
${ }^{94}$ Ver Finch (2005), Frega y otros (2008), Nahum (2003).

${ }^{95}$ Para considerar la censura piveliana ver el capítulo 7 de la presente Tesis.
} 
La confianza que se tenía en Pivel era tan importante que prácticamente todo aquello que tuviera que ver con historia, literatura y cultura nacionales debía pasar por sus manos. Existe un caso paradigmático a este respecto que lo tuvo como protagonista. Los diferentes tomos de la Colección..., antes de su impresión, necesitaban de una preparación en textos, compilación y corrección de todo tipo de errores. También debían cotejarse las diferentes ediciones del libro a editar, y los estudios biográficos y bibliográficos de los autores. Estos trabajos eran encomendados al Instituto Nacional de Investigaciones y Archivos Literarios —en adelante INIAL - , creado en diciembre de 1947, durante la presidencia del colorado Luis Batlle Berres.

Según lo dispuesto por la reglamentación de 1947, el INIAL tenía como cometido

\begin{abstract}
... reunir y custodiar los documentos relacionados con la obra y la personalidad de los autores uruguayos, así como todos aquellos otros testimonios de ese carácter, ilustrativos de una época; y realizar estudios metódicos y trabajos de divulgación con la base de los materiales que reúna y demás fuentes de consulta en poder de los organismos oficiales o existentes en colecciones particulares [...]. Los manuscritos, material bibliográfico y de cualquier otro carácter, propiedad de los organismos oficiales, útiles al cumplimiento de los fines que se cometen al Instituto, quedan afectados para la realización de sus investigaciones, en las condiciones y con las garantías que establezcan las propias autoridades directivas. ${ }^{96}$
\end{abstract}

La novel institución tenía un director que debía ser nombrado por el Poder Ejecutivo. El funcionario debía ser una persona «de notoria versación en la materia» (Ley 11032). Además, se estableció el monto de veinte mil pesos anuales para los gastos del Instituto y la publicación de documentos.

La dirección fue asumida por Roberto Ibáñez ${ }^{97}$ desde la creación del INIAL hasta su escandalosa disolución. El 5 de octubre de 1961, el Ministerio de Instrucción Pública se hizo cargo de una investigación contra el director del INIAL. La causa, según se supo, fue un viaje a México y Cuba sin la autorización correspondiente, que tomó estado público gracias a una publicación periódica. El 24 de octubre se decidió alejar a Ibáñez del cargo, y en su lugar poner a un director interino: Pivel. Durante su conducción, se publicó una guía con los pasos a seguir para consultar los materiales del INIAL, lo cual era altamente necesario, según el Ministro de Instrucción Pública. ${ }^{98}$

Ibáñez reaccionó con una nota en Marcha, del 29 de diciembre de 1961. En ese texto, titulado «Notas a una interpelación», el suspendido director del INIAL defendió su gestión y

\footnotetext{
${ }^{96}$ Ley 11032 (3/1/2018), Parlamento Uruguayo, obtenido de: parlamento.gub.uy.

${ }^{97}$ Poeta, docente y ensayista, se hizo cargo además del prólogo de Ismael de Eduardo Acevedo Díaz (1953) en la Colección...

${ }^{98}$ AGNU, Ministerio de Instrucción Pública y Seguridad Social, caja 767.
} 
responsabilizó al cambio de bandería política por la falta de presupuesto. También sostuvo que el otro objetivo que se trazó el Partido Nacional fue el de removerlo de su cargo. Además, acusó al Ministro de querer hacer política con el INIAL y de convertirlo en «una oficina pública más». En la nota omitió el nombre de Pivel, pero aludió a él al referirse al «director-custodio», lo que permitía múltiples interpretaciones: ¿sería custodio de los materiales del INIAL o custodio en tanto funcionario policial... $?^{99}$

Para desprestigiar a la figura de Ibáñez, el Ministro de Instrucción Pública, Pons Etcheverry, acusó al ex director de impedir la consulta de los archivos existentes, y en especial el de José Enrique Rodó. Ibáñez contradijo al Ministro, afirmando que más de cien investigadores habían hecho uso de los servicios que brindaba el INIAL, según constaba en los registros. Además, citó algunos de sus «prestigiosos» nombres: Eugenio Petit Muñoz, Hugo D. Barbagelata y José Pedro Segundo. Finalmente, con respecto al reglamento de consulta, sancionado durante su ausencia y redactado por Pivel, Ibáñez contestó que él había remitido uno en abril sin obtener respuesta, por lo que la falta de reglamento respondía más a una omisión de las autoridades que a la de su propia persona. ${ }^{100}$

El 14 de noviembre de 1962, el Ministro Pons Etcheverry destituyó al antiguo director del INIAL, pero éste presentó un recurso de revocación que nunca pudo ser tenido en cuenta por la Justicia, ya que no contaba con los sellos ni los timbres necesarios. Sin embargo, por un breve lapso Ibáñez pudo volver al cargo — en enero de 1963-, aunque al retornar se encontró con nuevos colaboradores, contratados por Pivel mientras había sido director interino. Esta situación provocó que las partidas presupuestarias del INIAL se consumieran en salarios.

Durante el ministerio de Pivel, el 28 de diciembre de 1964 se derogó la Ley 11032 que creaba el INIAL y, en su lugar, las anteriores atribuciones pasaron a ser asumidas por el nuevo Departamento de Investigaciones de la Biblioteca Nacional. ${ }^{101}$ Esta nueva institución pasó a ocuparse de los estudios previos y la preparación de los textos para la Colección...

En enero de 1965, Ibáñez hizo entrega de los documentos y del dinero que restaba del arqueo de caja del INIAL. Además, presentó una carta de renuncia ante el Ministerio, en la que defendía su actuación al frente del Instituto y acusaba a Pivel de desmantelarlo. ${ }^{102}$

\footnotetext{
${ }^{99}$ Ibáñez, Roberto (29/12/1961), «Notas a una interpelación», Marcha, Montevideo, p. 7.

${ }^{100}$ Ibáñez, Roberto (29/12/1961), «Notas a una interpelación», Marcha, Montevideo, p. 7.

${ }^{101}$ Recordemos que Tabaré A. Pradeiro (en 1955 había participado en la Revista Histórica de Pivel, publicando «La Plutónica. Contribución a la bibliografía uruguaya», en vol. 23) fue nombrado jefe del Departamento, quien semestralmente informaba al Ministro Pivel de todo lo que se hacía.

${ }^{102}$ AGNU, Carta de Roberto Ibáñez, 12 de enero de 1965, Ministerio de Instrucción Pública y Seguridad Social, caja 767.
} 
El 24 de febrero de 1967 Pivel, como Ministro saliente, elevó una breve misiva al Ministerio de Instrucción Pública en la que aplaudía los dos años de trabajo del nuevo Departamento. En referencia a la anterior carta de Ibáñez, sintetizó:

El firmante consideró que no podía detenerse a contestar la extensa elucubración suscrita por el Sr. Roberto Ibáñez [...]. El juicio que existe sobre la gestión cumplida por el INIAL, de la que existen abundantes pruebas en expedientes archivados en este Ministerio, y la eficacia de la labor desarrollada por el mencionado Departamento de Investigaciones, relevan al que suscribe de todo comentario. ${ }^{103}$

Era habitual en Pivel este tipo de respuestas — más bien soberbias_-, donde resaltaba su gestión y, para contrarrestar las anteriores, remitía a documentos o archivos donde se demostraba que tenía razón, sin argumentar ni entrar en largas polémicas. También en este tipo de estrategias se confirma su propia construcción de un poder hegemónico.

El principio del desmantelamiento del INIAL, y su posterior desaparición, tuvo como nexo el trabajo de Pivel. Todos los colaboradores del nuevo Departamento de Investigaciones debían revestir la total confianza y acatamiento de las órdenes pivelianas. Debemos señalar que, entre los asiduos ayudantes del Departamento, se encontraban José Pedro Barrán ${ }^{104}$, Benjamín Nahum ${ }^{105}$, Elisa Silva Cazet y María Angélica Lissardy ${ }^{106}$, todos jóvenes profesores discípulos de Pivel.

Como sabemos, el editor-Ministro concentró poder y delegó algunas tareas a su estricto círculo de colaboradores. Por primera vez, la Colección ... tenía el dinero, con los funcionarios y la mirada directriz de su más interesado director. Los resultados los sabemos: 85 tomos en cuatro años, ${ }^{107}$ que constituyeron la parte central de toda la serie de obras publicadas por el Estado hasta hoy.

\footnotetext{
${ }^{103}$ AGNU, Carta de Juan Pivel Devoto, 24 de febrero de 1967, Ministerio de Instrucción Pública y Seguridad Social, caja 767.

${ }^{104}$ Además de discípulo de Pivel durante sus años de estudiante en el IPA fue uno de los historiadores más prolíferos en temas y publicaciones que tuvo Uruguay. Durante su juventud tuvo inclinaciones marxistas para luego en su etapa madura estar más cerca de la Escuela de los Annales. Si bien estuvo alejado de su antiguo maestro, hacia el final de su carrera le terminó rindiendo homenaje. Fue docente del IPA y de Humanidades, hasta el día de hoy los estudiantes del IPA mantienen el enfrentamiento con sus homólogos de la Universidad y como forma de chanza citan que el mejor historiador de la historia del Uruguay era profesor.

${ }^{105}$ Trabajó durante gran parte de su carrera en tándem con Barrán. Se dedicó mayoritariamente a la historia económica dentro de la Universidad. Actualmente es Director de Historia Económica en la Facultad de Ciencias Económicas y Administración (UdelaR).

${ }^{106}$ Tanto Silva Cazet como Lissardy no continuaron sus carreras como historiadoras.

${ }^{107}$ Esto arroja un promedio de 21 volúmenes anuales, lo que representó el número más alto de su historia. Por ejemplo, en un año de los reseñados, se publicaron casi la misma cantidad de tomos que en el período 1970-1979, cuando se imprimieron solo 22 libros.
} 


\section{Un ejemplo dentro de la red intelectual piveliana}

Como hemos observado, las redes intelectuales que fue conformando Pivel, en su etapa previa a ser director del MHN, lo ayudaron a escalar posiciones dentro de la administración pública. Sin embargo, ¿qué sucedió posteriormente? Desde una posición hegemónica, ¿cómo conformó Pivel sus redes intelectuales? ¿Quiénes participaron de ellas?

Si inicialmente vimos cómo, desde una posición subordinada, Pivel tejió logros para conseguir una mejor posición en el campo intelectual uruguayo, en este caso veremos cómo otros personajes del ámbito cultural buscaron al historiador nacional para sus respectivos beneficios. En especial, trabajaremos el caso de Alfredo Castellanos, quien apeló al apoyo de Pivel para conseguir dineros públicos para la publicación de su investigación histórica sobre la ciudad de Montevideo.

\section{El primer prólogo piveliano}

En 1957, algunos de los miembros directrices de la comisión editora de la Colección... decidieron llamar por primera vez a Pivel para que se hiciera cargo de un prólogo. El estudio encomendado versaba sobre la obra de Isidoro de María, cuyo tema era la ciudad de Montevideo, pionera en su género, que fuera editada a finales del siglo XIX, y llevara por nombre Montevideo antiguo.

Allí, Pivel señaló la importancia que este libro debía tener para los historiadores futuros. Pretendía, además, establecer un programa detallado de una posible obra que comprendiera aquellos puntos que consideraba de interés para historizar la ciudad.

Leamos su larga sugerencia:

Una historia en la que sean estudiados, conjuntamente con los orígenes del presidio que fue Montevideo, las luchas por el dominio del Río de la Plata que determinaron su fundación; el destino militar del Real de San Felipe, la misión que cumplió como plaza fuerte; el esfuerzo de sus pobladores para conquistar y extender el dominio de la jurisdicción terrestre; la vida del puerto, la rivalidad con Buenos Aires, los azares del contrabando y la misión del apostadero; una historia que explique el papel que le cupo a Montevideo en el proceso de la independencia nacional y en la etapa previa de las Invasiones inglesas, el espíritu portuario que animó a sus dirigentes y su aversión a los caudillos; una historia que estudie sin pasión el destino político, militar y económico de la ciudad de Montevideo en la conjunción de intereses y de ideas que originó la Guerra Grande del Río de la Plata, durante la cual, sitiada ocho años, culminó la notoriedad universal que le acompañó desde sus 
orígenes; una historia que desentrañe las causas del antagonismo entre la ciudad y el medio rural hasta que el equilibrio de ambas corrientes determinó la unidad del país; la influencia económica del puerto de Montevideo en ese proceso de unificación centralizadora; una historia, en fin, que al estudiar las etapas de la transformación material de Montevideo, reconstruya la fisonomía y restaure el color de cada época a través del cuadro de costumbres y de la escena de ambiente y señale, a la vez, las corrientes inmigratorias que contribuyeron a la formación de una sociedad plástica y receptiva, sensible a todas las corrientes del pensamiento universal (Pivel, 1957, pp. 22-23).

Los volúmenes que salieron a la calle poseían por primera vez la firma de Pivel. Pero hagamos un salto temporal hasta 1969, doce años después, para conectar el prólogo de la Colección... con el concurso historiográfico que detallaremos más adelante. En el medio: la victoria del Partido Nacional en 1958, y su posterior afianzamiento en el poder, que lo hará ganar nuevamente las elecciones cuatro años más tarde. El país dejaba de lado el neobatllismo. Sus sueños suizos eran historia, salvo por la estructura orgánica del Poder Ejecutivo colegiado, que no soportó la crisis económica y que sucumbió finalmente hacia 1966 (Caetano y Rilla 1999, Frega 2008).

Pivel, quien aparece nuevamente en escena, tuvo un largo pasaje al frente del Ministerio de Instrucción Pública y Seguridad Social entre 1963 y 1967, lo que lo convirtió en el director de la Colección... y en una figura que trascendió los aspectos partidarios, siendo aclamado como el intelectual oficial del Estado nacional.

Otra vez en Montevideo, durante 1969, y nuevamente bajo un gobierno colorado, se realizó un llamado a concurso desde la Junta Departamental para escribir trabajos inéditos que tuvieran como tema la «Historia de la ciudad de Montevideo: características de su evolución política, social, cultural y urbanística»(Castellanos, 1971). El premio consistía en una retribución económica muy importante para un país en años de crisis, y la publicación del trabajo como libro. Entre los integrantes del jurado se encontraba — cuándo no- Pivel. El ganador del concurso fue el profesor Alfredo R. Castellanos, quien utilizó el seudónimo de Pedro Millán. ${ }^{108}$ Su trabajo se editó en 1971, bajo el nombre Historia del desarrollo edilicio y urbanistico de Montevideo (1829-1914).

\section{Montevideo}

Originalmente, Montevideo antiguo, de Isidoro de María, fue un libro que presentó cuatro tomos editados entre 1887 y 1895 . Formalmente, ese texto presentaba pinceladas costumbristas,

\footnotetext{
${ }^{108}$ Millán fue quien estableció el primer plano y puso los límites a la ciudad de Montevideo, durante el inicio de su proceso de fundación en 1726.
} 
con cortos capítulos (más cercanos al formato de viñetas), ahondando en temas relacionados con la ciudad de Montevideo, como sus primeros pobladores, el cabildo, el alumbrado público, el campo santo o la primera botica, entre otros.

En 1957 se publicó una versión en la Colección..., dividiendo el texto en dos tomos con un total de 680 páginas. Además, se hizo una reedición en 1976.

En su prólogo, Pivel describió a De María como un autodidacta que, pese a que «no había realizado estudios superiores como otros hombres de su generación favorecidos por la fortuna, las amistades o por la posición familiar», sustituyó su falta de formación por «la experiencia de vida, el trato con los hombres y la necesidad de ilustrarse como podía sobre todos los problemas a que lo obligaba el ejercicio del periodismo» (Pivel, 1957, p. 8). Finalmente, anotó que su sustento fue asegurado gracias a ser director del Archivo Público en 1906. También Pivel era un autodidacta, y durante su trayectoria como intelectual oficialista parecía ver con buenos ojos lo hecho por el reseñado, por lo que decidió resaltar este punto en su estudio previo (luego repitió este gesto con otros autores, como con su «maestro» Francisco Bauzá). En este sentido, la semblanza de De María era una forma indirecta de autolegitimación intelectual.

Además, Pivel anotó que la curiosidad de De María por la historia fue consecuencia de su tarea diaria de redactor de periódicos. Al ser uno de los primeros con semejantes preocupaciones, su trabajo, que fue editado como Montevideo antiguo, fue una simple crónica tradicionalista, sin la rigurosidad científica que tuvieron otros autores como Bauzá. El mérito que le encontró el prologuista, y la justificación para publicarlo, fue haber ayudado a exaltar la identidad nacional (Pivel, 1957, p. 15).

Inicialmente citamos el programa que Pivel pensaba legar a los futuros historiadores. Quizás deberíamos hacer un análisis detallado para comprender el alcance del punteo llevado adelante en el prólogo. Es por eso que inicialmente me permití transcribir la larga cita con que inicia este segmento por su unidad discursiva y lógica.

El extenso programa que pretendió influir en los estudios posteriores, que llevarían adelante los futuros historiadores, no fue para nada cándido, porque llevaba la marca historiográfica de Pivel. El hecho de que una figura tan importante para el campo intelectual e historiográfico uruguayo resaltara una serie de tópicos para una futura investigación sobre la capital del país representaba una directriz imposible de obviar.

Pivel creía que una futura obra histórica sobre Montevideo debía señalar cómo habían sido sus orígenes, las disputas frente a Buenos Aires por el dominio del estuario rioplatense, y su posterior consolidación como ciudad puerto fundamental para la región. Claramente, esta 
idea remarcaba la conocida lucha de puertos, discurso dominante a nivel histórico con respecto a la relación entre ambas ciudades. ${ }^{109}$

Pivel también advertía la importancia de observar cómo Montevideo se había transformado, de enclave dicotómico frente al medio rural, a protagonista de la unidad nacional, para lo cual volvía a exponer sus ideas respecto del enfrentamiento entre caudillos (del interior del país y de representantes de sectores populares) y doctores (de la ciudad, letrados e integrantes de las elites), binarismo que siempre mantuvo en su discurso historiográfico. Finalmente, señaló que el período historizado no debería culminar más allá de los primeros años del siglo XX.

El prólogo fue utilizado por Pivel para direccionar las miradas, al referir las virtudes y los defectos de la obra de De María. Lo que el autor no pudo hacer originalmente, por su falta de materiales y de experiencia historiográfica, debía ser continuado por los jóvenes historiadores. La lectura que hiciera el prologuista buscaba constituirse como hegemonizante, al determinar el trabajo que estaba bien hecho y advertir lo que faltaba hacer.

En este sentido, además del lectorado ampliado, Pivel daba una orientación práctica a los historadores. En el caso del prólogo de Pivel, observamos cómo se hizo explícita la necesidad de influir sobre el público lector al que estaba orientado dicho estudio previo: los historiadores. Si bien, como marcamos anteriormente, la Colección ... estaba pensada para un público amplio, no de especialistas, con este trabajo inicial el lectorado interpelado parecía cambiar.

\title{
El concurso y Alfredo Castellanos en la red intelectual piveliana
}

\begin{abstract}
En octubre de 1968, se hizo un pedido formal por parte del edil colorado Héctor Massiotti para llamar a un concurso que historiara a la ciudad de Montevideo. La excusa, la falta de libros que hicieran «un estudio profundo de fuentes documentarias aun [...] inexploradas». El órgano encargado de organizar el llamado sería la Junta de Montevideo ${ }^{110}$ como «heredera de una tradición de gobierno y política comunal» (Castellanos, 1971).
\end{abstract}

Para narrar la historia de Montevideo se establecieron por entonces dos concursos: uno para llevar adelante una historia de la ciudad de Montevideo, y otro para dar cuenta de los barrios montevideanos, pudiéndose elegir uno o más de los tantos existentes. El anonimato en absolutamente todas las instancias estaba asegurado o, por lo menos, eso parecía.

\footnotetext{
${ }^{109}$ Posteriormente, Arturo Bentancur (1997 y 2011) pondrá en duda y echará por tierra esta conceptualización.

${ }^{110}$ Especie de Poder Legislativo de los departamentos en que se divide Uruguay.
} 
Cada uno de los concursantes debía presentar sus trabajos bajo seudónimo, entregar cuatro copias y un sobre lacrado con su verdadera identidad. El manuscrito debía presentarse, a través de un representante, en la primera mitad del mes de julio de 1970, en el edificio de la Junta Departamental, en el corazón de la Ciudad Vieja. ${ }^{11}$

El jurado, que recibía una remuneración por su tarea, tenía hasta fines de agosto de ese año para presentar su veredicto, y estaba integrado por dos representantes de la Junta (el profesor Dr. Eugenio Petit Muñoz y el Arq. Fernando García Esteban) y uno del Instituto Histórico y Geográfico del Uruguay (Prof. Simón Lucuix).

Los premios que se otorgarían eran de $\$ 250.000^{112}$ para el ganador y $\$ 150.000$ para el segundo, además de la publicación de la obra para el primer puesto con un tiraje de dos mil ejemplares.

Como ya hemos dicho, el ganador fue Alfredo Castellanos.

El libro se componía de tres partes, divididas cronológicamente: La «Ciudad nueva» (1829-1865), La «Ciudad novísima» (1865-1872) y El «gran Montevideo» (1872-1914).

Dentro del corpus encontramos numerosas citas (785 en total) de larga extensión, acordes al estilo piveliano. El estudio ganador contaba con muy buena cantidad de bibliografía y de fuentes primarias y secundarias (donde estaban las publicaciones del propio Pivel), aunque llama la atención que el anónimo Castellanos cite su propia investigación publicada en el cuaderno n 22 (febrero de 1969) de Marcha, con el título: «Montevideo entre dos siglos. 18901914, Guión cronológico».

En la obra publicada por Marcha se hacía un recorrido histórico por el origen de los barrios montevideanos y sus puntos de referencia urbanísticos, siguiendo los cambios a través de la cronología presentada. Quizás podríamos resumir gran parte del libro con palabras ya leídas anteriormente: «una historia, en fin, que al estudiar las etapas de la transformación material de Montevideo, reconstruya la fisonomía y restaure el color de cada época a través del cuadro de costumbres y de la escena de ambiente» (Pivel, 1957, p. 23).

Al momento de fundamentar el voto por el ganador, Petit Muñoz y Lucuix expresaban que el trabajo presentado

\begin{abstract}
... es un modelo de investigación científica por la amplitud y multiplicidad de direcciones del panorama que abarca, la riqueza del aporte de datos, bibliográficos, de hemeroteca y de archivo, que en torno a cada uno de los aspectos tratados han sabido acumular, haciéndolo, además con solvencia y prolijidad técnicas inobjetables, y que revelan una labor metodológica y
\end{abstract}

\footnotetext{
${ }^{111}$ Núcleo inicial de la ciudad amurallada de Montevideo.

${ }^{112}$ Como referencia, seis tomos de la obra de Lenin de la Editorial Pueblos Unidos costaban \$250 (Marcha n. ${ }^{\circ}$ 1486, 20 de marzo de 1970).
} 
sistemática de años de búsquedas pacientes; por el acierto con que ha salvado del olvido nombres y cosas que deben quedar registrados, $y$, sobre todo, por la inteligencia y la oportunidad con que ha sabido seleccionar, para su transcripción, así las páginas representativas de época de poderosa eficacia evocadora, como las cifras y los coeficientes estadísticos significativos (Castellanos, 1971).

Por su parte, el Arq. García Esteban prefirió votar por la obra compuesta por Carlos Altezor y el Arq. Hugo Baracchini. Finalmente, al quedar en minoría, decidió cambiar el voto y pedir el segundo puesto para dicho trabajo, probablemente debido a la presión del resto del jurado (historiadores con cierto peso institucional).

Por lo que se desprende de las resoluciones, se hace evidente que existieron otros integrantes del jurado, que no tenían voto, entre los que estaban el Prof. Flavio García, el Arq. Leopoldo Artucio y Pivel. Este último conocía las investigaciones de Castellanos. Montevideo era una ciudad chica en tamaño y en población, además de poseer un campo historiográfico también reducido, por lo que la envergadura del manuscrito entregado por Castellanos no podía pasar desapercibida. El jurado sabía quién era el autor que, a la postre, se convirtió en el ganador.

Para hacer visible el vínculo de Castellanos con Pivel podemos citar, por ejemplo, la biblioteca de Pivel, ${ }^{113}$ que cuenta con siete ejemplares dedicados por Castellanos. Llaman la atención tres de ellos: los dos primeros pertenecen a la obra Nomenclatura de Montevideo, en dos versiones distintas: una editada en 1962 y otra en 1978. ${ }^{114}$ La tercera dedicatoria pertenece a la obra que ganó el concurso: Historia del desarrollo edilicio y urbanístico de Montevideo (1829-1914), de 1971.

La proximidad entre ambos historiadores también se puede rastrear en otra de las publicaciones orientadas y dirigidas por Pivel, como la Revista Histórica (segunda época, 19421982), de la cual Castellanos fue uno de los colaboradores más prolíficos, publicando cuatro artículos (amén de que la esposa de Castellanos, Aurora Capillas, también fue editada con igual cantidad de aportes). ${ }^{115}$

\footnotetext{
${ }^{113}$ Allí se encuentra actualmente casi toda la biblioteca personal de Pivel. Consta de treinta mil volúmenes, y pertenecen al acervo de la Universidad de Montevideo (cedido por el partido Nacional). Tengo que señalar que dicha Biblioteca todavía no se ha catalogado enteramente. Según mis últimas consultas, queda más del $70 \%$ de los libros por ser ingresados al sistema. Este aspecto supuso un problema importante para iniciar mi estudio de la fuente, ya que tuve que trabajar de forma individual con cada volumen de la Biblioteca, de los veintemil que se calcula que tiene.

${ }^{114}$ En su primera edición se lee: «Para Pivel, este libro, fruto de una de sus tantas iniciativas como concejal de Montevideo»y, en la segunda: «Para Pivel que apadrinó la primera edición de este trabajo» (biblioteca privada Pivel Devoto).

${ }^{115}$ Solo superado por cinco de los 77 autores que publicaron durante los años reseñados.
} 
Como integrante de la red intelectual piveliana, Castellanos pudo ganar el concurso al cumplir paso a paso las directivas de nuestro protagonista (que fueran expuestas en el prólogo estudiado). El constante diálogo con una de las figuras hegemonizantes del campo historiográfico nacional le permitió hacerse fácilmente con el premio.

Debemos tener en cuenta algunos puntos que se resumen en esta breve historia de la red intelectual que se fue consolidando alrededor de Pivel. Tal como señalamos más arriba, los concursos históricos anónimos, en la ciudad de Montevideo (y podríamos afirmar, en todo el Uruguay), no eran ni tan concursos ni tan anónimos. La pequeñez del campo historiográfico, claramente hegemonizado desde la posición omnipresente de Pivel, hacía prácticamente imposible escapar de sus directivas. Cada concurso hecho desde el Estado estaba pensado con nombre y apellido, aunque se guardaban las formas del anonimato. En ese sentido, los premios eran una forma de apoyar el trabajo de investigación llevado adelante por los historiadores de la red piveliana.

El Estado se comportaba como mecenas, sin importar el color político que condujera sus riendas. Pivel no iba a dejar que personas por fuera de su ámbito intelectual se hicieran con los concursos. Ésta era una forma de mantener su hegemonía, ya que podía otorgar ciertos beneficios a los investigadores más jóvenes, al integrar éstos sus redes intelectuales. El círculo se completaba: si se iba en busca del apoyo de Pivel, se podían obtener trabajos rentados dentro del Estado, asegurarse la publicación de diferentes investigaciones, ganar nombre, sumar contactos, pero se debían seguir las directrices pautadas por Pivel: sólo la fidelidad permitía la persistencia en el campo.

Además, podemos ver el funcionamiento del prestigio cultural e historiográfico obtenido por Pivel gracias a su obra intelectual, ya que tanto el prólogo que citamos al inicio de este trabajo, como el llamado a concurso, se dieron durante gobiernos colorados, siendo él integrante del Partido Nacional, y de referencia para el elenco político.

Cuando presentamos esta breve historia, pensamos en hacer visibles los hilos que conectaban a todas estas figuras tan distintas pero íntimamente ligadas. Fue Pivel el protagonista que cumplió diversos roles: editor, prologuista, jurado, historiador y político. Este papel multifacético se inscribe en un campo intelectual poco diversificado, muy concentrado en Montevideo, y donde todavía los historiadores no se habían consolidado como profesionales con autonomía. La poca cantidad de investigadores, generalmente organizados en torno a la figura rectora piveliana, podían continuar sus estudios consiguiendo las pocas ayudas económicas brindadas por el Estado gracias a las redes intelectuales que fueron tejiendo. 


\section{Conclusiones parciales}

Durante su largo recorrido, Pivel demostró ser una personalidad fundamental para entender el funcionamiento del concepto de identidad nacional en Uruguay.

Desde las épocas del joven Pivel, hemos podido reconstruir el periplo de su carrera intelectual como historiador, gracias a las redes intelectuales que fue tejiendo con los años. El capital social traído desde su lugar de nacimiento, y sus vinculaciones religiosas, partidarias y académicas, sumadas a las condiciones centralizadas del campo intelectual local, y a la muy incipiente profesionalización de la disciplina historiográfica, lo pusieron a Pivel en condiciones de hegemonizar el campo historiográfico, con su particular visión de la historia nacional.

Luego de tomar la casi vitalicia dirección del MHN, su posición dentro del campo y sus posturas sobre la historia nacional cambiaron sensiblemente. A partir de 1940, y como consecuencia de la carga simbólica que tenía el nuevo cargo, Pivel se centró en producir una historiografía coherente y unificadora sobre los partidos políticos en Uruguay. Su producción historiográfica, a partir de 1945, pasó a estar centrada en la misión auto-encomendada de escribir una versión oficial del pasado nacional.

Observamos que los múltiples proyectos posteriores en los que intervino, dentro de la administración estatal, reforzaron las posturas de algunos historiadores que habían buscado los orígenes de la nación en la época colonial, como en el caso más importante de Bauzá, convirtiéndose a sí mismo en su último sucesor. Por tanto, la auto-consagración será una marca distintiva de su vida intelectual en la madurez.

Gracias a su militancia política dentro del Partido Nacional, llegó al cargo más importante en términos de poder estatal para sus aspiraciones, como Ministro de Instrucción Pública y Seguridad Social, entre 1962 y 1966. Esos cuatro años de mandato lo tuvieron como máxima autoridad en materia educacional y cultural, algo que significaba orientar partidas de dinero hacia los proyectos que le parecían esenciales. El proyecto más favorecido fue editar obras canónicas en términos literarios e historiográficos, en el seno de la Colección... que aquí estudiamos.

Como sabemos, durante su estancia en el Ministerio, ejerció la presidencia de la Comisión Editora de la serie de libros estatales y fue editor y prologuista. Bajo la firma de Pivel se estampaba, por primera y única vez en todo el catálogo de la Colección..., un poder simbólico que difícilmente podía pasar desapercibido.

Si este historiador, editor, Ministro, intelectual y prologuista elegía hacerse cargo de los 76 tomos que se publicaron durante los años de su período de gobierno, la oficialidad con la 
que contaba la Colección... suponía entender que la construcción canónica en la elección de autores, obras y posiciones críticas sobre ellas, era imposible de obviar.

La construcción de nuevas redes intelectuales terminó de consagrarlo, al repartir dineros públicos entre autores y obras que seguían sus lineamientos. El edificio se sostuvo hasta el final.

Luego de su muerte, su inmensa obra sigue en pie, construida durante tantos años sobre sólidas bases de poder estatal, fáctico y simbólico, y que supone, para nuestras generaciones, uno de los edificios historiográficos más sólidos que haya existido en toda la Historia del Uruguay. 


\section{CAPÍTULO 4}

\section{LA FORMA DEL LIBRO}

Caminar entre las librerías de viejo en Montevideo es algo habitual para el público lector. La calle Tristán Narvaja aloja la mayoría de ellas. Entre 18 de Julio y Paysandú se encuentran todo tipo de libros, desde las últimas novedades hasta aquellas reliquias buscadas por los coleccionistas.

Los domingos, en medio de la feria que ocupa las calles, los libreros sacan sus puestos a la vereda para mostrar sus ofertas. Sus compradores se dividen entre los habituales buscadores de oportunidades, y los simples curiosos que, seducidos por un ejemplar o convencidos por el vendedor, se hacen del objeto-libro. Por su parte, los extranjeros saben de su existencia gracias a guías, páginas de internet o recomendaciones de los lugareños, por lo que también recorren este sitio.

Excepto cuando llueve, ver los colores de los libros en los escaparates, formando un extraño pero pintoresco arcoiris en el medio de la ciudad gris, suele ser una vista habitual de las calles montevideanas en el barrio Cordón. Además de los colores, los olores. Los libros viejos y los nuevos poseen un aroma que, aunque estemos con los ojos cerrados, podemos reconocer.

Hay ejemplares entremezclados de literatura, historia, medicina, derecho, filosofía y parapsicología. Hay ofertas de grandes enciclopedias desechadas por el espacio que ocupan, gracias al triunfo de Wikipedia. Hay libros nuevos que cuentan con un improvisado envoltorio transparente para no ser dañados por manos curiosas. Hay revistas literarias, históricas, de cine, de chismes viejos y pornográficas — tapadas con anacrónicas bolsas negras, por miedo a miradas infantiles o mojigatas- Hay manuales escolares y liceales que fueron comprados y vendidos hasta el hartazgo, desgastados por tantas horas de estudio y por sus diversos dueños. Hay una Babilonia entera, donde se observan palabras en castellano, inglés, francés, alemán y hasta ideogramas japoneses. Entre tantos olores, el de humedad. Entre tantos libros y colecciones, la Biblioteca Artigas de Clásicos Uruguayos.

Como dijimos, la Colección de Clásicos Uruguayos fue la primera serie de libros editada por el Estado uruguayo que pretendió construir un canon literario, que se ha mantenido hasta el 
día de hoy, y que ha contado con un éxito relativo y variable durante sus más de sesenta años de publicación.

Asumiendo los aportes metodológicos abordados anteriormente, ${ }^{116}$ podemos encarar el estudio del libro desde varias aristas, incluyendo su materialidad, su recepción y circulación. En este capítulo, nos centraremos precisamente en los aspectos formales del objeto en sí y su justificación; además, consideraremos el catálogo de títulos de la colección y sus respectivos prólogos, la política de precios y distribución, la impresión y conformación de cada uno de los tomos a nivel formal, y la relación con los derechos de autor.

\section{La justificación de la Colección...}

Las colecciones de libros surgen por muy diversos factores, incluyendo desde la intención de popularizar un catálogo, abaratando los ejemplares (Abraham, 2016; Chartier, 1994), respondiendo por ejemplo a la necesidad de lucro de las editoriales, hasta la voluntad de difundir valores estéticos o ideológicos determinados, moldeando así la formación de un público lector (Rama, 1981; Dalmaroni, 2006; Degiovanni, 2007; De Diego, 2014; Mailhe, 2016).

Establecer un catálogo, que funcione bajo un sello editorial, supone una planificación, que va desde los títulos que se incluyen hasta los aspectos de la materialidad de la serie, para que sea reconocible por el consumidor.

Si tenemos en cuenta el concepto de "colección de libros", para entender la relación existente -dentro del mercado- entre el sello editorial y el comprador, deberíamos considerar que la creación de colecciones en general ha sido asociada con la variable económica (el consumidor piensa que el precio al que accede le es más ventajoso, siendo entonces el elemento que, en definitiva, decide la compra), aunque también es importante considerar la variable "cultural": el lector descansa en la seguridad de que lo que va a leer, en la colección, ha sido previamente seleccionado en base a un criterio formativo o estético válido, y por ende entra en una categoría (por unidad de género literario, tema, disciplina, etc.), y que es «bueno» (o como en nuestro caso, «clásico»).

Durante el siglo XX, el Estado uruguayo tuvo varias publicaciones oficiales que suponían un proceso de selección de obras. Además de la Colección..., también se imprimió el Archivo Artigas (1950) — que editaba todos los documentos relacionados con la vida del caudillo oriental-, y posteriormente se publicó la Biblioteca de Autores de la Literatura Universal (1963-1966), y las Páginas ejemplares de la literatura uruguaya (1962), todas colecciones de

$116 \quad$ Ver el Capítulo 1. 
corta existencia y éxito. Por tanto, la única serie de libros dirigida al gran público, y que persistió en su publicación hasta el día de hoy, fue la Colección ... ${ }^{117}$

Si nos remontamos a los aspectos legales que dieron inicio al proyecto editorial del Estado, debemos recordar que el 14 de agosto de 1950 se estableció el marco legal y económico $^{118}$ para la creación de la Colección... Desde la conformación de su catálogo, se pretendió crear una selección de obras que dieran cuenta de lo más selecto de la producción intelectual uruguaya, creando así un canon literario e histórico oficial. Tres años después, salió el primer tomo a la calle, y se dio inicio a una lista que ha seguido alimentando los escaparates de las librerías hasta nuestros días.

Con respecto a la Colección ..., desde el nombre con que se bautizó este proyecto editorial, se remitió a la figura de José Artigas: como consecuencia del centenario del fallecimiento del prócer uruguayo, el gobierno estableció la creación de una comisión encargada de seleccionar, preparar y editar — con dinero público - una serie de libros accesibles al ciudadano común, a fin de estimular el sentimiento nacional.

El título de «Artigas», para la serie de libros, puede resultar extraño, sobre todo si se considera que, si bien muchas de las obras editadas tuvieron como objetivo aportar una base historiográfica pro-artiguista (que sustentara el culto al «padre de la patria»), no tiene sentido para el resto de los libros — de historia, literatura, geografía, derecho, etc.—, que son una importante porcentaje de libros.

Recordemos que en 1950 se conmemoraba el centenario de la muerte del prócer, pero el primer tomo salió tres años después. ¿Qué sentido tenía, entonces, mantener el título de una colección alejada cronológicamente del aniversario que le dio el nombre, y que además, no se inscribía dentro de la historiografía artiguista...?

Sospechamos que el motivo fue económico. ¿Sería Artigas una excusa para pedir presupuesto para la edición de libros en su nombre? ¿Algún político podría negarse a otorgar dineros públicos a un proyecto que llevara la insignia estatal junto con la del prócer nacional?

\footnotetext{
${ }^{117}$ Si bien el Archivo Artigas se sigue editando hasta el día de hoy, no supone una selección de obras sino de documentos.

${ }^{118}$ La Ley 11473 establece que «Artigas: se da un plan para concertar diversas iniciativas que reflejen en conjunto la gloria del padre de la patria, con motivo del centenario de su muerte. [...]. Artículo 14. Asígnase al Ministerio de Instrucción Pública y Previsión Social la cantidad de doscientos mil pesos $(\$ 200.000,00)$ para iniciar la publicación de una Biblioteca de Autores Clásicos Uruguayos, que se denominará Biblioteca Artigas. A tal efecto, créase una Comisión presidida por el ministro de Instrucción Pública e integrada por el director del AGNU, el director de la Biblioteca Nacional y el director del MHN. Dentro del plazo de treinta días, el Poder Ejecutivo reglamentará el funcionamiento de dicha Comisión» (www.parlamento.gub.uy, visto: 25 de diciembre de 2017).
} 
Creemos que relacionar la palabra «uruguayo» con la de «Artigas», en el título de la Colección..., fue un acierto simbólico de los políticos colorados, administradores del Estado que buscaron hacer esto de manera deliberada.

Aquellos que constituyeron el proyecto cultural, en sus primeros años de vida, terminaron demostrando el éxito de sus intenciones, al continuar la edición de la Colección... más allá del pasaje de los diferentes gobiernos democráticos, la dictadura cívico-militar de 1973-1985, y los primeros años del siglo XXI.

La coronación simbólica del esfuerzo cultural, llevado adelante por los colorados, fue cuando se editó el primer tomo de la Colección..., con el volumen Artigas de Carlos María Ramírez (1953). Esta obra, entre las primeras en reivindicar al caudillo y relacionar su accionar político con la nueva nación uruguaya, era la base para la defensa historiográfica del país, que necesitaba construirse bajo la sombra de un prócer lo suficientemente neutral cómo para conseguir el apoyo de todo el espectro político.

Su exordio, firmado por Justino Zavala Muniz, quien era Ministro de Instrucción Pública y Previsión Social de la época, contiene una justificación que sirvió para toda la serie de libros:

En ocasión de cumplirse el primer centenario de la muerte de JOSÉ ARTIGAS, los Poderes Públicos del Uruguay, intérpretes de la fervorosa gratitud popular, decretaron los máximos honores a la memoria del Prócer. Entendiendo que para alcanzar una profunda comprensión del extraordinario hecho humano que fue la vida de ARTIGAS, no bastaba el conocer su solo y personal pensamiento, sino el de su pueblo contemporáneo y del surgido a la libertad por su esfuerzo, decretaron por la Ley la creación de esta Biblioteca de Clásicos Uruguayos ${ }^{119}$ (Zavala Muniz, 1953, p. 7).

Como decía el discurso ministerial, el motivo de la creación de la Colección... se basaba inicialmente en Artigas, frente a quien el Estado interpretaba la «fervorosa gratitud popular», pero esto no era otra cosa que una justificación simbólica para emprender el proyecto. Sin embargo, esos intérpretes, designados por el Ministro como los «poderes públicos del Uruguay», actuaron definiendo la supuesta gratitud del pueblo para con Artigas como emblema de la colección de libros canónicos.

Según Zavala Muniz, el prócer oriental era la razón para llevar adelante el esfuerzo editorial; el pueblo que lo rodeó y que quedó en libertad gracias a su figura, era por extensión

${ }^{119}$ Mayúsculas en el original. 
el nuevo objeto de estudio y análisis. La selección de obras era una manera de acercarse a la nación y también a Artigas.

Sin embargo, es erróneo considerar que aquello conocido como el «ideario artiguista» fuera consecuencia de su «solo y personal pensamiento», dejando de lado la multiplicidad de fuentes y secretarios en los que Artigas se apoyó durante su vida política pública. La imagen del caudillo, construida sistemáticamente por el Estado nacional, no podía radicar únicamente en la política oficial, sino que también debía alcanzar su corolario cultural.

Obviamente es inexacta la identificación a la que es sometida la imagen de Artigas con la de «su» pueblo. Recordemos que, como caudillo y gobernante, el contacto personal que tuvo con los pobladores de la Banda Oriental — llamada Provincia a partir de 1813-, como principal caudillo, fue de nueve años - aunque el control total del territorio fue de menos de dos años.${ }^{120}$ En consecuencia, sostener que quienes rodearon a Artigas fueron transformados por él en ese corto lapso de tiempo, ${ }^{121}$ y que dichos cambios, en esencia, fueran imprescindibles para la construcción de un país (que en momentos de la publicación del prólogo referido, ya contaba con poco más de 120 años de historia), podría ser arriesgado en términos cualitativos y cuantitativos.

Además, su figura como prócer de la patria recién fue establecida a fines del siglo XIX. El pueblo oriental nacería huérfano de padre, y sin consciencia de su existencia hasta muy entrada la adultez. Por tanto, es netamente difícil creer que haya crecido a su imagen y semejanza, como expresaba el Ministro.

Proseguía el exordio, señalando que

...en la etapa de cultura que hemos alcanzado, bien está que revisemos documentadamente el camino andado en el breve tiempo de vida civilizada del Uruguay.

Las presentes y futuras generaciones podrán, estudiando el pensamiento escrito de quienes contribuyeron a crear el perfil del espíritu del país, ahondar en la comprensión de nuestro venidero destino (Zavala Muniz, 1953, pp. 7-8).

En el primer sintagma, el Ministro advertía que el Uruguay había alcanzado un nivel cultural supuestamente avanzado, y que era necesario estudiarlo documentalmente. Esas etapas culturales responden a un pensamiento positivista de supuesto progreso de las naciones.

\footnotetext{
${ }^{120} \mathrm{Si}$ bien su participación en el cuerpo de Blandengues fue incluido en su construcción como caudillo, no era la figura más sobresaliente del período.

${ }^{121}$ A nivel historiográfico se establece como hecho fundador del concepto de «pueblo oriental» el llamado Éxodo de 1811 (llamada «redota» por sus contemporáneos, o la «emigración» en los documentos de Artigas). Véanse Beraza (1967); Reyes Abadie y otros (1968) Frega (2001 y 2015).
} 
También la palabra «civilizada» debería ser cuestionada: ¿será la producción artística y académica «culta» un indicio de civilización? Ese «breve tiempo andado», ¿se inicia con la llegada de los españoles? ¿Es previo, o posterior incluso a la creación del Uruguay como nación?

La aparición del concepto «civilización» en el texto, heredado del esquema de Sarmiento expuesto en el Facundo (1845), converge con la perspectiva dominante en el sector doctoral del Partido Colorado, lo que presentaba una dicotomía con los caudillistas, que fueron en gran medida representados por el Partido Nacional - ya que asumieron, dentro de su recorrido político, elementos que los acercaban más a la campaña que a la ciudad—. ${ }^{122}$

Recordemos que Pivel, futuro director de la Colección..., fue uno de los defensores del caudillismo. Por ende, es probable que el Ministro blanco no estuviera en nada de acuerdo con estas líneas citadas y desglosadas anteriormente, por lo menos con esta interpretación de lo que sería la civilización para Zavala Muniz.

Además, según la idea subrayada en la cita precedente, la base de la Colección... estaba en buscar de dónde venía la identidad cultural que diferenciaba a los uruguayos respecto de las demás naciones. Lo que se seleccionaba, por parte de la Comisión Editora, debía tener en cuenta solo a los autores fundamentales y, por lo tanto, nacionales.

Para que las generaciones siguientes entendieran el desarrollo cultural de los uruguayos, tenía que existir un conglomerado de grandes obras que demostrara sintéticamente las raíces documentales de su conformación y «venidero destino». La existencia del país, en términos políticos, debía justificarse sobre la base de una amalgama cultural interna. La vecindad del pequeño Uruguay con los gigantes Brasil y Argentina, convertían su singularidad cultural en algo muy frágil.

Más adelante continuaba el prefacio:

Somos sin duda, por razones históricas y geográficas, un hecho insólito en el proceso de la cultura universal.

De ahí que no baste, para explicar nuestra fisonomía de pueblo culto, el estudio de las leyes generales que han ordenado el desarrollo del espíritu de los pueblos de cuyas culturas milenarias nos nutrimos, ni aún mismo el de aquellos que habitan este Continente Americano. Más aún: a pesar de la profunda hermandad histórica, dentro de la genérica expresión de lo rioplatense, hay acentos propios ya advertidos en los primeros días de estos pueblos y que van acentuándose hasta establecer diferenciaciones nítidas en el transcurso de la historia.

\footnotetext{
${ }^{122}$ Con esta afirmación, no podemos caer en el error, bastante extendido, de pensar que los colorados fueran enteramente un partido político de doctores, y los blancos de caudillos, ya que en ambos bandos existían figuras con elementos del campo y de la ciudad.
} 
Todo ello está en germen o es ya expresión definida, en el pensamiento de nuestros autores clásicos.

A través de sus páginas se advierten las heroicas esperanzas y las vicisitudes de esa aventura del espíritu que es el signo de nuestra personalidad (Zavala Muniz, 1953, pp. 8-9).

Según Zavala Muniz, Uruguay era un hecho único, y por ende sus habitantes eran diferentes al resto de los pueblos americanos. Y esa diferencia se había construido desde el período colonial, gracias a un gran número de obras, que merecían un lugar en una colección nacional. Para recalcar dicha incompatibilidad con el resto de los americanos, era necesaria una justificación de alguna índole, que tuviera validez para todos los uruguayos, y para aquellos que aún no los reconocían como insólitamente cultos frente a las letras de dominio universal.

La Colección... buscó enfatizar ese germen de diferencia. Esos «acentos propios» eran señalados como aspectos fundadores de la singularidad, construyendo mayoritariamente «lo uruguayo» (por ejemplo, en contraste con «lo argentino», dentro del estuario platense).

¿Cuáles eran esos gérmenes de diferencia? ¿De qué manera se podían interpretar, desde la edición de los libros canónicos, esas marcas nacionales que se desprendían de las obras coloniales? ¿Dónde hacer foco? ¿Con qué elementos? Creemos que estas preguntas pueden ser respondidas analizando, por ejemplo, los prólogos encargados especialmente para cada volumen. Esas cuestiones no podían ser resueltas libremente por los lectores; debían ser materia de demostración para el nacionalismo cultural, y el Estado debía presentarlos ya debidamente procesados para los lectores de las obras clásicas. Por lo tanto, la elección de los prologuistas fue fundamental para cumplir estas tareas.

El Ministro de Instrucción Pública terminó concluyendo que,

... como lo afirma el informe de la Comisión parlamentaria, «la obra literaria histórica y científica, publicada en el siglo pasado por aquellos autores que ya podemos considerar como nuestros clásicos es, en el presente, totalmente desconocida por las nuevas generaciones, no por falta de inquietud, ni porque esas obras dejen de seguir suscitando un vivo interés, sino simplemente porque son inhallables. Muchas de ellas no han visto jamás la forma del libro; han quedado dispersas de distinta índole, de donde corresponderá exhumarlas. Otras se encuentran totalmente agotadas desde hace casi medio siglo [...]. Es nuestra esperanza fundada, que esta empresa de revisión y popularización de nuestros clásicos sea, una vez culminada, seguida por la edición de nuestros autores contemporáneos.

Habremos dado así un paso más en el proceso feliz de nuestra superación cultural (Zavala Muniz, 1953, pp. 9-10).

Así, desde el Estado se buscaba que la Colección ... cumpliera con un primer objetivo: volver a poner a circular fuentes que ya hacía mucho tiempo habían desaparecido del mercado. Además, 
el Ministro afirmaba que, si había un desconocimiento de ellas, no era debido a la falta de inquietud intelectual de un pueblo tan culto como el uruguayo, sino más bien a las dificultades para acceder a tales textos. En este sentido, la Colección... buscaría devolverle al lectorado nacional las raíces que éste desconocía respecto de su propio origen, las representaciones simbólicas de un pasado cultural perdido que sería imprescindible recuperar para afirmar la identidad como diferencia.

El gobierno buscaba así fomentar la circulación de libros, anticipando algo que la generación crítica se encargó de vociferar mayoritariamente desde el semanario Marcha: la falta de un mercado de libros uruguayos, amén de lo alejado que las publicaciones nacionales solían estar respecto del interés del ciudadano medio. La Colección ... era entonces una vía para crear un nuevo público lector, atento al canon de la literatura y del pensamiento nacionales.

La tarea emprendida por el Estado tenía múltiples aristas: seleccionar autores que respondieran al calificativo de «clásico uruguayo», reorganizar la obra dispersa de muchos autores para difundirla entre las generaciones contemporáneas y futuras, y reeditar libros de nula o baja circulación, para cohesionar y reafirmar el sentimiento nacional en el plano cultural.

Ahora bien, ¿cuáles eran las obras «clásicas»? Si ya preexistían «clásicos de la literatura uruguaya», ¿quién había establecido ese canon...? ${ }^{123}$ Según puede leerse en la cita anterior, debían existir dos etapas diferenciadas a la hora de llevar adelante la edición. La primera, de revisión y popularización de los clásicos del siglo XIX. La segunda, de publicación de los «contemporáneos», es decir, de autores del siglo XX que acompañaran el desarrollo mismo de la Colección.... De este modo, este proyecto editorial buscaba así la integración de clásicos perdidos y de nuevos títulos llamados a consagrarse como clásicos.

Sin embargo, lo planteado en el primer tomo se contradijo, en apariencia, inmediatamente con el segundo volumen. Como mencionamos, la obra Artigas, escrita en 1884 y reeditada en 1897 por Ramírez, fue la que dio inicio a la Colección... Pero en el tomo 2, publicado en 1953 (el mismo año del volumen 1), nos encontramos con Fermentario de Carlos Vaz Ferreira, un libro sin prólogo y de un autor contemporáneo, ${ }^{124}$ que además, había publicado ese volumen en 1938, siendo luego reimpreso en 1940. Pasó lo mismo en otras dos publicaciones de 1953, que también fueron de Vaz Ferreira: Sobre los problemas sociales (tomo 5) y Sobre la propiedad de la tierra (tomo 6).

\footnotetext{
${ }^{123}$ Ver Capítulo 6.

${ }^{124}$ Carlos Vaz Ferreira ya era un filósofo conocido a nivel regional e internacional. Su importancia, dentro del ámbito cultural, siempre fue destacada por parte del Estado uruguayo. Vaz Ferreira murió en 1958, viendo publicada gran parte de su obra en esta Colección...
} 
Estas supuestas contradicciones, al inicio del catálogo, nos permiten pensar que esas dos etapas arriba mencionadas se desarrollaron de forma simultánea. Además, creemos que las primeras obras editadas buscaron la rápida popularidad de la serie dentro del mercado, porque fueron ampliamente vendidas, y sus autores eran previamente reconocidos por el público lector.

Por otro lado, en el proyecto inicial, se tenían en mente infinidad de autores, pero no se contaba con un consenso. Lo mismo sucedía con las obras. Sin embargo, la forma definitiva de la Colección... se estableció hacia mediados de los años sesenta, ya que estuvo bajo los designios de Pivel, que fue su editor en jefe más prolífico.

Entonces, el primer problema que los editores tuvieron que resolver fue la configuración de su catálogo.

\section{El catálogo}

Un catálogo siempre supone una selección, de obras respecto de otros que por distintas causas no merecen (o no pueden) estar en dicha lista. Como ya hemos señalado, creemos que, en el caso de la Colección..., se buscó construir un canon, y que fue el Estado-editor, a través de sus funcionarios, el protagonista, como encargado, constructor y ejecutor de dicha tarea.

En nuestra investigación llegamos hasta 1982, ya que fue el año en que Pivel terminó sus funciones como integrante del Consejo editor. En consecuencia, los tomos que analizaremos serán 167 dentro de los primeros 29 años de edición.

La conformación del catálogo de la Colección... nos planteó varios problemas desde el inicio. Hablar del «Estado que editaba» implicaba una indirecta invisibilización de los individuos encargados de llevar adelante las distintas acciones que terminaron configurando la selección de obras, que pasó por varios gobiernos políticos.

Todas las decisiones de aquello que se imprimió, y de lo que no, fueron llevadas adelante por la Comisión Editora, ${ }^{125}$ que estaba integrada y presidida por el Ministro de Instrucción Pública y Seguridad Social, ${ }^{126}$ el director del MHN, el director del AGNU y el director de la Biblioteca Nacional — eran los tres directores de los tres repositorios de la historia documental del país-. En consecuencia, al tener una integración tan dinámica, ${ }^{127}$ las decisiones editoriales

\footnotetext{
${ }^{125} \mathrm{La}$ reglamentación de su funcionamiento fue establecida el 17 de setiembre de 1951, instalándose el 16 de octubre de ese año.

${ }^{126}$ Cambió varias veces de denominación durante el período estudiado, además de Instrucción Pública y Seguridad Social, también fue de Cultura (desde 1967), y de Educación y Cultura (desde 1970).

${ }^{127}$ Para poner un ejemplo, los ministros de Cultura, durante el período estudiado, fueron 19, de distintos partidos políticos, bajo integraciones del Poder Ejecutivo bien diferentes, y dentro del período democrático y dictatorial.
} 
fueron variando, aunque el nombre que se mantuvo por más tiempo dentro de la comisión fue solo el de Pivel.

Una de las primeras preguntas que nos formulamos es cuál fue la justificación esgrimida por la Comisión, para que una obra fuera considerada «clásica», y por ende seleccionada para integrar la colección. En la primera rendición de cuentas, ante la Cámara de Representantes, en 1956, el Ministro de Instrucción Pública aclaró que las obras clásicas serían las que «pudieran tomarse por modelo digno de imitación o que fueron notables en algún concepto, que son las acepciones de la expresión clásico aplicables en esta circunstancia». ${ }^{128}$ Se trata entonces de una definición muy amplia. Pero lo que sucederá, de hecho, es que lo clásico será definible, en cada período ministerial, dependiendo de los cambios políticos e historiográficos.

Probablemente, desde las filas del Partido Colorado, no se pensaba en un recambio de filiación política dentro del Poder Ejecutivo. Hacía más de noventa años que los colorados gobernaban de manera consecutiva, y el país todavía no tenía los signos de la crisis económica que terminó ayudando al recambio político-partidario. Cuando Pivel tomó las riendas de la comisión, gracias a la victoria del Partido Nacional, la Colección... tomó otra dirección, y además adoptó definitivamente el color y aspecto que le impuso su editor durante 23 años.

Esas características del catálogo se fueron conformando a medida que los libros aparecieron en el mercado. En consecuencia, consideramos que el ritmo de publicaciones de la Colección... tuvo cuatro etapas respecto del caudal de su edición. Inicialmente, la considerada el punto de partida que llamaremos la «génesis colorada» (1953-1959), con un desarrollo que se concentró en los primeros años del proyecto, ya que necesitaba de una base para poder continuar a posteriori. En segundo término, los «años dorados», durante la estancia de Pivel en el Ministerio de Instrucción Pública y Seguridad Social (1963-1967), donde los recursos ejecutados convirtieron la Colección... en un proyecto cultural fundamental. Durante este período, se conformó la impronta que ha tenido la serie de libros hasta el momento. En la tercera etapa, encontramos un «estancamiento y decadencia» (1968-1982), con muy pocos tomos que todavía salían a la luz. El freno en la edición fue establecido sobre todo durante la dictadura cívico-militar (1973-1985), que se limitó a gastar los dineros públicos con la salida de algunos volúmenes que saciaran la escasa necesidad cultural del régimen. Y por último, el «resurgimiento», que se encontraría fuera de nuestro objeto de estudio, con el nombramiento en 2006 del director honorario Wilfredo Penco, que ha reactivado la salida de los tomos y la continuidad del proyecto.

\footnotetext{
${ }^{128} \mathrm{AGNU}$, Carta de Clemente Ruggia al presidente de la Cámara de Representantes Juan Rodríguez Correa, Ministerio de Instrucción Pública y Seguridad Social, caja 589, carp. 3138. Subrayado en el original.
} 
Retomando la citada carta del Ministro Clemente Ruggia, donde había expuesto una lista de autores - pero no de obras - que se pensaba imprimir en el proyecto editorial, debemos señalar que muchos de los nombres barajados finalmente se integraron al proyecto, pero otros no corrieron la misma suerte. ${ }^{129}$ En dicha nómina inicial se proyectaba la edición de libros mayoritariamente de figuras políticas de los dos partidos tradicionales. La mayor parte de los nombres pertenecía a personalidades del siglo XIX, y que por ende, casi en su totalidad, estaban muertos. Las obras editadas buscaban balancear políticamente la lista, ya que se buscaba la neutralidad, representada por la realidad gestada en el Consejo Nacional de Gobierno. ${ }^{130}$

Durante los primeros años, las obras que se publicaron eran predominantemente literarias, siguiéndole en las preferencias la historia, el derecho y la geografía. Sin embargo, también se manifestó en palabras del ministro colorado, que había que diversificar los tópicos tratados por la Colección..., para difundir «nuevos aspectos de la civilización en el país». ${ }^{131}$

Si la colección de volúmenes editados tenía que responder a la imagen de un país culto, había que demostrar que en Uruguay no solo se hacían libros de literatura e historia, por lo que posteriormente se imprimieron libros sobre derecho, pedagogía, ciencias naturales, arte, de polémicas y discursos de políticos, aunque esa producción fue bastante acotada. En el catálogo no había obras de otras ramas de las ciencias sociales — como por ejemplo la sociología o la antropología — ni de ciencias exactas — física, matemática, química—, ni de otras expresiones artísticas. En consecuencia, el impulso inicial de los primeros tomos impresos por el Estado no se mantuvo, y fue muy variable en el tiempo.

\footnotetext{
${ }^{129}$ Aquellos no editados y aparecidos en la lista fueron José de Archavaleta, Domingo Arena, Francisco y Manuel Araucho, Manuel B. Acosta, Eduardo Acevedo, Martín Aguirre, Abdón Arostegui, Enrique de Arrascaeta, Baltasar Brum, Juan Manuel Blanes, Aurelio Berro, Antonio Bachini, Samuel Blixen, Ramón de Cáceres, Angel Floro Costa, Teófilo Díaz, Anacleto Dufort y Alvarez, Dermidio de María, Fermín Ferreira y Artigas, Rafael Fregeiro, Heraclio Fajardo, Elbio Fernández, Eugenio Garzón, Daniel Granada, Julio Herrera y Obes, Manuel Herrero y Espinoza, José Irureta Goyena, Cándido Juanicó, Enrique Kubly, José Benito Lamas, Juan Francisco Martínez, Julio Raúl Mendilaharzu [sic], Daniel Muñoz, Orosmán Moratorio, Carlos Maeso, Tristán Narvaja, Lucas Obes, José Prego de Oliver, Melchor Pacheco y Obes, Antonio Pereira, Alberto Palomeque, Carlos María de Pena, Santín Carlos Rossi, Mariano Soler, José maría Sienra y Carranza, Joaquín de Salterain, Ramón de Santiago, Duvimioso Terra, Santiago Vázquez, Jerónimo Villademoros, Jacobo Varela, Alfredo Vázquez Acevedo y Eusebio Valdenegro (AGnu, Carta de Clemente Ruggia al presidente de la Cámara de Representantes Juan Rodríguez Correa, Ministerio de Instrucción Pública y Seguridad Social, caja 589, carp. 3138).

${ }^{130}$ Como consecuencia de la reforma constitucional de 1952, se creó un órgano ejecutivo colegiado con seis representantes del partido mayoritario y tres de la minoría mayor. En resumidas cuentas, tanto blancos como colorados querían perpetuarse en el gobierno compartido. Recién en 1967 se volvió al presidencialismo, culpando al colegiado por la falta de iniciativas respecto de la crisis económica que enfrentaba el Uruguay luego de la caída del modelo sustitutivo de importaciones (1933-1958) y del programa fondomonetariasta — aplicado a partir de 1959, luego de la firma de la primera carta de intención con el organismo internacional—.
}

${ }^{131} \mathrm{AgNu}$, Carta de Clemente Ruggia al presidente de la Cámara de Representantes Juan Rodríguez Correa, Ministerio de Instrucción Pública y Seguridad Social, caja 589, carp. 3138. 
Desde el punto de vista cuantitativo, el catálogo presenta algunos problemas entre la edición y la impresión de los tomos. Cabe destacar que los años de publicación que figuraron en las tapas no siempre coincidieron con los años de impresión de muchos de los volúmenes. Esta situación se volvió palpable a partir de 1965. El caso más llamativo es el del tomo 93 (los Escritos Filosóficos de Prudencio Vázquez y Vega): si bien figuraba en tapa que había sido editado en 1965, se terminó de imprimir el 20 de noviembre de 1968 (aunque estuviera compaginado en 1965). También sucedió lo mismo entre los tomos 91 y 100: si bien en todas las tapas aparecía como fecha de edición 1965, se terminaron de imprimir en fechas dispares entre 1966 y 1967. Esta confusión entre la impresión y la edición tuvo que ver con aspectos económicos por los que estaba pasando el Estado y, en consecuencia, también el país. Si bien los tomos estuvieron listos durante los años que aparecieron en las tapas, la ejecución de los presupuestos se demoraba demasiado y las imprentas no realizaban los trabajos hasta no disponer del dinero. Además, como el número de ejemplares era muy elevado para el mercado uruguayo, las empresas corrían riesgos económicos si las obras se imprimían antes de cobrar, lo que retrasaba su salida a la venta. Teniendo en cuenta esta cuestión - entre otras-, nos centraremos en la edición ${ }^{132}$ y no tanto en la impresión, dado que ésta modifica y aleja el verdadero trabajo llevado adelante durante la administración de Pivel al frente de su Ministerio.

Desde el primer año de edición hasta 1958, cuando finalizó el gobierno colorado, la Colección... editó 28 volúmenes iniciales, de los cuales 11 salieron a la venta en el primer año (1953).

Luego de la apuesta inicial al proyecto cultural nacional, se gestó un cambio de gobierno que detuvo momentáneamente la edición. Entre 1959 y 1962, durante el primer colegiado del Partido Nacional, salieron solo seis tomos a la venta, evidenciando el poco interés en la continuidad del proyecto colorado, y el ajuste en los gastos, sobre todo luego de la primera carta de intención con el Fondo Monetario Internacional (FMI).

Sin embargo, con la nueva victoria de los blancos en las elecciones de 1962, hubo un cambio en el gabinete ministerial, y como sabemos, Pivel se hizo cargo del Ministerio de Instrucción Pública y Seguridad Social. Durante ese período, se desarrolló la base mayoritaria de la serie, con la impresión de ochenta volúmenes nuevos.

Luego de los tímidos — pero importantes — ocho tomos iniciales durante 1963 — pues nunca, desde el primer año en que se había editado la Colección ..., se habían publicado tantas obras-, el historiador nacional hizo reaparecer al Estado como editor de obras clásicas.

\footnotetext{
${ }^{132}$ Para el total de tomos editados por año, ver gráfico en Anexo.
} 
1965 fue el mojón más importante de toda la historia de la Colección..., ya que se editaron 44 obras, lo que estableció un récord, y demostró una capacidad de trabajo muy importante para el medio nacional. De hecho, el promedio de edición de un tomo cada ocho días no deja de sorprender hasta el día de hoy.

Durante la estadía ministerial de Pivel, se establecieron los tres años consecutivos con más edición de libros, el ya mencionado 1965, junto a 1964 y 1966, donde se terminaron 14 tomos en cada año, sumando 62 volúmenes en total. Los restantes 53 tomos, del corte cronológico de nuestro objeto de estudio, fueron hechos en los quince años posteriores, para sumar un total de 167 volúmenes en el período 1953-1982.

Si analizamos la impresión, ${ }^{133}$ los números cambian, pero se mantienen algunas variables. 1965 sigue siendo el año récord, con 34 títulos salidos al mercado, seguido por 1966 con veinte, y 1964 y 1967 con 14 cada uno. Durante el Ministerio de Pivel, finalmente se imprimieron 76 volúmenes diferentes, lo que mantiene la importancia de su período por sobre el resto.

La impresión se concentró en dos períodos: entre 1953 y 195828 tomos, y entre 1963 y 1970 104, sobre un total de 163 volúmenes impresos durante el período de estudio.

Estos datos evidencian falta de uniformidad en la impresión, que fue hija de los cambios de gobierno, de las marchas y contramarchas en las políticas culturales y editoriales, siempre dependientes de los ministros, y de la grave crisis económica de estancamiento e inflación que afrontó el Uruguay durante la mayor parte del período señalado.

Desde el punto de vista cualitativo, debido a la gran cantidad de títulos editados, decidimos analizar las obras literarias e historiográficas, para observar en ellas cómo se asentaron las características del nacionalismo cultural buscado por el Estado uruguayo.

Mayoritariamente, los autores de la serie de libros estudiados eran hombres, ${ }^{134}$ nacidos en Uruguay o nacionalizados, y pertenecientes a sectores dominantes de la población. La Colección... le ofrecía al lector la garantía implícita de que lo adquirido de por sí era un material serio y de buena calidad.

En ningún caso se editaron textos anónimos; generalmente eran obras de autoría asumida, o en algunos casos polémicas o artículos de personalidades de la política y de la administración estatal. Excepcionalmente se editaron algunas antologías literarias e historiográficas. Por ejemplo, se preparó y editó un tomo que reunía artículos de tema nacional histórico — donde se

\footnotetext{
${ }^{133}$ Para el total de tomos impresos por año, ver gráfico en Anexo.

${ }^{134}$ Solo tres de los 167 tomos fueron de mujeres: de María Eugenia Vaz Ferreira, Juana de Ibarbourou y Delmira Agustini.
} 
puso el nombre de todos los autores en la tapa-, pero ésto recién ocurrió durante los años de la dictadura en 1975. En el caso de la literatura, se realizó una Antología de poetas modernistas menores (tomo 139, de 1971), sin que figure el autor de la selección.

Entre las obras históricas, observamos una línea divisoria en términos cronológicos. De las 11 obras impresas por la Colección... durante nuestro corte cronológico, ${ }^{135}$ cinco fueron inicialmente editadas en el siglo $\mathrm{XIX}^{136} \mathrm{y}$ seis en el siglo $\mathrm{XX},{ }^{137}$ siendo las más cercanas en el tiempo la de Pablo Blanco Acevedo —editada inicialmente en 1936, y publicado por la Colección... en 1975- y la de Juan Antonio Rebella — que salió en la Revista Histórica en 1933, y fue impresa por la serie en 1981.

Con respecto al canon historiográfico, se editaron tres obras panorámicas de la historia del Uruguay - las de Magariños Cervantes, Bauzá y de la Sota-, concebidas en el siglo XIX, y estudios específicos sobre el período colonial, el artiguismo y la nacionalidad. Estos tres temas tienen una íntima relación, ya que la Colección ... busca asentar el origen de la nación uruguaya en la colonia española, algo que el propio Pivel se ocupó de justificar durante toda su obra histórica. Si la colonia y el artiguismo gestaron la nación uruguaya, ese discurso histórico necesitaba de estudios eruditos dentro del campo historiográfico que avalaran la hipótesis y la sostuvieran de manera científica.

Llama la atención que, como dijimos, las únicas obras del siglo XX ingresadas en el canon llegaron cronológicamente en su primera edición hasta 1936, lo cual marcaba una falta historiográfica de 46 años - teniendo en cuenta el último tomo editado durante la administración de Pivel en 1982 - ¿QQué obra y autor podría salvar el vacío histórico dejado por la Colección....? Ese sería el propio Pivel...

Centrándonos en lo publicado durante la estancia de Pivel en el Ministerio, y según lo que recogen los documentos de la época, la mayor parte de lo editado en la Colección... fue decidido por el propio Pivel. En 1963, publicó a Magariños Cervantes, y en 1965 a de la Sota y a Bauzá. Cabe resaltar que, en todos los casos, los prólogos fueron realizados por el propio

\footnotetext{
${ }^{135}$ Tomamos como obras, aquellas que fueron pensadas de esa manera por sus autores, en varios volúmenes hay artículos, diarios de batalla, crónicas y miscelánea con contenidos históricos que no fueron tenidos en cuenta.

${ }^{136}$ Esas obras fueron Historia del territorio oriental del Uruguay (Juan M. de la Sota, 1841); Estudios históricos, políticos y sociales sobre el Río de la Plata (Alejandro Magariños Cervantes, 1854); Artigas (Carlos María Ramírez, 1884); Montevideo Antiguo (Isidoro de María, 1887-1895); Historia de la dominación española en el Uruguay (Francisco Bauzá, 1880-1897).

${ }^{137}$ Esas obras fueron Las Instrucciones del Año XIII (Héctor Miranda, 1910); Época colonial. La compañia de Jesús en Montevideo (Carlos Ferrés, 1919); La independencia nacional. Tomo II (Pablo Blanco Acevedo, 1922); La cruzada de los Treinta y Tres (Luis Arcos Ferrand, 1925); Purificación. Sede del protectorado de «Los Pueblos Libres» 1815-1818 (Juan Antonio Rebella, 1933); El Gobierno Colonial en el Uruguay y los orígenes de la nacionalidad (Pablo Blanco Acevedo, 1936).
} 
Ministro, aspecto que remarca su entera responsabilidad y gusto personal por la edición de los autores reseñados.

En el campo de las obras literarias, en general se trató de expresiones relacionadas con escuelas literarias decimonónicas —con una marcada presencia del romanticismo, el naturalismo y el nativismo-, y distantes respecto de las nuevas formas de escritura vanguardistas que se desarrollaron entre las décadas del veinte y del sesenta, reforzando así el perfil conservador de la serie, que consolida el papel de "clásicos" para textos ya consagrados por la crítica y por las colecciones preexistentes. En efecto, ese carácter conservador no permitió la impresión de autores contemporáneos. Un ejemplo es el de Felisberto Hernández, ${ }^{138}$ quien ya había publicado varias de sus obras más importantes como Por los tiempos de Clemente Colling (1942), El caballo perdido (1943), y Nadie encendía las lámparas (1947), y que se había convertido en una referencia ineludible para los críticos de la Generación del 45, como también lo era Juan Carlos Onetti. Tampoco fueron publicadas Armonía Somers o Cristina Peri Rossi - solo para citar otros ejemplos de autores vinculados a la proyección de las vanguardias durante el despliegue de la Colección ...-.

Entre los textos literarios incluidos en este proyecto editorial, cuatro autores dominaron abiertamente la Colección ...: Juan Zorrilla de San Martín (con 13 obras), Carlos Reyles (con seis), y Eduardo Acevedo Díaz y Acuña de Figueroa (con cinco). Estos exponentes de la centralidad del canon nacional ya eran «clásicos de la literatura uruguaya» desde hacía mucho tiempo. ${ }^{139}$

Una vez elegidos los autores y obras a editar, el círculo de edición tenía un segundo paso. Cada uno de los tomos editados presentaba un prólogo que, entre otros objetivos, apuntaba a señalar la contemporaneidad de esos «clásicos».

\section{Los prólogos}

Pivel pretendía que cada prólogo que integraba la serie de libros fuera escrito por un investigador especialista en la temática o en el autor de la obra. Los prologuistas eran escogidos por la Comisión que, en algunos casos, daba las directivas sobre el tipo de trabajo que se pretendía.

\footnotetext{
${ }^{138}$ Cabe destacar que Hernández recién tuvo lugar en la Colección... en 2016, cuando se publicó Nadie encendía las lámparas.

${ }^{139}$ Sobre este tema ver el Capítulo 6.
} 
Quien estuvo la mayor cantidad de tiempo como encargado de este punto fue Pivel, como ya hemos señalado.

Todos los prólogos buscan orientar la atención del lector hacia lugares específicos, subrayando la importancia del texto prologado. Domina la presencia de prólogos escritos en clave erudita, que exigen un conocimiento previo general sobre literatura, historia, derecho, sociología y otras ramas del conocimiento. Sin embargo, los textos más antiguos fueron actualizados en su vocabulario y ortografía, para volverlos legibles con fluidez en el presente.

Los prólogos se escribieron con un nivel cultural digno de los sectores cultos de la población, interpelando a las capas medias, para consolidar la nación a través de difusión de la cultura letrada nacional. Aprximándose al caso estudiado por Mailhe (2016) sobre la Biblioteca Humanior, la Colección... pretendió establecer un pacto de lectura con un lectorado amplio y de sectores medios, incluidos como consecuencia del avance de la educación secundaria y terciaria en el país, para ampliar la difusión de la crítica literaria y la historiografía nacionales, entre otras áreas.

A menudo los prólogos agregaban un inconveniente al proceso de edición, pues varios retrasos en la publicación de los volúmenes dependían de la tardanza de los prologuistas. Sin embargo, se comentaba que «esto es bien explicable en un país donde esta actividad intelectual no constituye el 'modus vivendi' de sus escritores, quienes tienen la mayor parte de su tiempo comprometido en otras actividades de las que obtienen sus ingresos». ${ }^{140}$ Generalmente, los autores de los prólogos eran integrantes de la Generación crítica, y compartían sus horas de escritura y práctica del oficio de escritor, junto con algún empleo público que desempeñaban, o con sus actividades como docentes que les permitían percibir un salario para la subsistencia. ${ }^{141}$

Sin embargo, no todos entregaban tarde sus trabajos. Por ejemplo, el 27 de julio de 1965, se pidió a José Antuña, por parte de Pivel, que se hiciera cargo del prólogo de la obra de Luis Melian Lafinur titulada Las mujeres de Shakespeare. ${ }^{142}$ La velocidad con que se concretó el pedido y su contenido fue de beneplácito para el editor, ya que el tomo se terminó de imprimir seis meses después del pedido.

Una de las razones del desgano y atraso de los prologuistas era que los pagos que se realizaban llegaban tarde y eran difíciles de cobrar, como se puede observar en la vasta

\footnotetext{
${ }^{140}$ AGNU, Ministerio de Instrucción Pública y Seguridad Social, Carta de Clemente Ruggia al presidente de la Cámara de Representantes, Juan Rodríguez Correa, caja 589, carp. 3138.

${ }^{141}$ Contaba Benedetti, quien había sido dueño del primer best-seller con El país de la cola de paja (1960), que su verdadero sustento era su empleo público en el Banco República, y no la venta de sus libros.

${ }^{142}$ AGNu, Carta a José G. Antuña, Archivo Pivel Devoto, caja 254, carp. 894.
} 
documentación del Ministerio. ${ }^{143}$ Los prólogos de los primeros tomos se pagaban $\$ 100$ cada uno, a precios de mayo de 1955 (hasta Soledad de Acevedo Díaz). Por tanto, y para poner un ejemplo, el pago que realizaba el Estado para con el especialista era equivalente a la venta de 67 libros de la Colección... (teniendo en cuenta que, durante los primeros años, el ejemplar se vendía a $\$ 1,5) .{ }^{144}$

Durante el período estudiado, los pagos sufrieron modificaciones lógicas debido al proceso inflacionario. Hacia 1964, el prólogo se cobraba en torno de \$300, mientras que en 1965 el pago subió hasta los \$ 500 y, entre 1966 y 1967 aumentó un $100 \%$ anual. ${ }^{145}$

Si bien contribuir en la Colección ... no era algo muy rentable, permitía visibilidad y prestigio intelectual, ya que muchos de los nombres de los distintos prologuistas se encuadraban dentro de los mejores críticos del país, ${ }^{146}$ mayoritariamente integrantes del staff del semanario Marcha.

Una vez establecidos los prólogos, y corregidos los errores en las hojas de prueba, el material estaba listo para ir a la imprenta. Cada uno de los pasos fue seguido por Pivel muy de cerca, tal como demuestran sus documentos. Desde la elección del tomo hasta su salida del Ministerio, todo era supervisado personalmente, para tener como producto final una edición cuidada y bien reputada dentro del campo cultural.

El proceso de conformación del objeto «libro» debía pasar por diversos controles y trámites burocráticos, por tratarse de una edición estatal. Además, existían disposiciones legales, respecto a los derechos de autor que era imprescindible acatar.

\section{El libro: su forma física}

Los escaparates y anaqueles de las librerías poseen cientos o miles de libros, de todos los formatos, colores y tamaños. La clave de una colección es ser identificable. En el caso de la dirigida por Pivel, ha sido bien significativo su formato: generalmente se la reconoce por sus ca-

\footnotetext{
${ }^{143}$ AGNU, Ministerio de Instrucción Pública y Seguridad Social, caja 589, carp. 3138.

${ }^{144}$ Para poder visualizar mejor el tipo de salario que pagaba el Estado, podemos decir que ese mismo dinero daba para la compra de nueve pares de zapatos de hombre en liquidación (Marcha, 9 de julio de 1954) o 125 cajas de 20 cigarrillos cada una (Marcha, 6 de agosto de 1954).

${ }^{145} \mathrm{La}$ inflación en 1964 fue del 44 \%, en 1965 del $35 \%$, en 1966 del $49 \%$, y en 1967 el récord histórico del 136 $\%$

${ }^{146}$ Entre ellos se encontraban Emir Rodríguez Monegal, Ángel Rama, Domingo Luis Bordoli, Arturo Sergio Visca, Esther de Cáceres, Arturo Ardao, Carlos Real de Azúa, Walter Rela y el propio Pivel, entre otros.
} 
racterísticas físicas más que por su nombre o su catálogo, sobre todo entre el público no especializado. Además, es muy probable que toda biblioteca, medianamente completa en autores uruguayos, posea alguno de sus tomos.

Originalmente, se pensaba que cada uno de los libros debería tener una presentación muy sobria, con tapas verdes y títulos en letra roja, al tiempo que se empleó un papel económico dividido en pliegos, que le dio al libro un aspecto desprolijo, por los cortes irregulares de sus hojas. Estas características físicas marcaban el tipo de lector masivo que era interpelado. Los clásicos nacionales debían ser tratados con solemnidad, y la elección de sus tapas, la falta de ilustraciones, y la tipografía utilizada en los ejemplares transmitía coherentemente dicho mensaje.

Una de las primeras decisiones que se debía tomar se relacionaba con el tamaño del libro. Como se sabe, el plegado constituye un elemento importante para los libros desde su invención (Febvre y Martin, 2005; Cavallo y Chartier, 1998; Barbier 2015a). Generalmente, los tamaños dan cuenta de la importancia del ejemplar a imprimir. Por ejemplo, un libro in folio era un tomo con hojas plegadas una vez, ${ }^{147}$ o sea cuatro caras que podían ser impresas. Los libros se fueron achicando, desde el in-cuarto hasta los formatos más pequeños in-18. Durante el siglo XIX, los volúmenes grandes eran raros y más caros. En general, los libros se diferenciaban por su tamaño especial acorde al contenido: los in- 8 para la literatura considerada como «seria», y los in-12 para las ediciones baratas y populares (Genette, 2001, p. 20).

El tamaño elegido para la edición de la Colección... fue el formato in-16 — que rendía 32 páginas por hoja plegada-, el cual de alguna manera daba cuenta de la necesidad de establecer un tipo de libro de dimensiones consideradas populares o standard.

Una vez decididas las características del libro, la Comisión Editora llamó a licitación para encargar la impresión, señalando en los pliegos el tipo de calidad que pretendía en los tomos. Luego de analizadas las propuestas, el Estado se decidió.

Con respecto a las imprentas, las hubo varias y con distinto nivel de participación en la edición total de la Colección... Quizá esa fase de la producción de cada ejemplar fue la más crítica, porque el Estado dependía de un privado para la finalización del trabajo. Esta fue, por momentos, la única etapa no llevada adelante por el Ministerio - aunque podríamos sumar que, en otros casos, como veremos, la distribución fue hecha por terceros.

Analizando el libro-objeto, y teniendo en cuenta los planteos de Genette (2001), para llevar adelante un estudio pormenorizado de la Colección..., asumimos que todos los libros

${ }^{147}$ Cada hoja sin plegar mide $118,8 \mathrm{~cm} \times 84,1 \mathrm{~cm}$. 
poseen paratextos. Estos, a su vez, están compuestos por los llamados peritextos — previos a la existencia material del libro-y epitextos - posteriores a su creación como objeto- En nuestro caso, sería pertinente trabajar con los epitextos que nos darán una visión panorámica distinta en el estudio del objeto-libro.

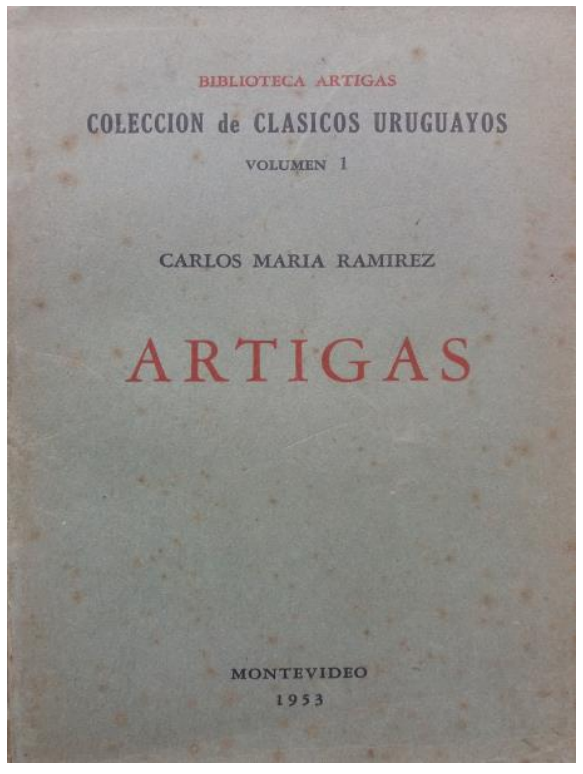

Ramírez, Carlos María (1953). Artigas. Vol. 1

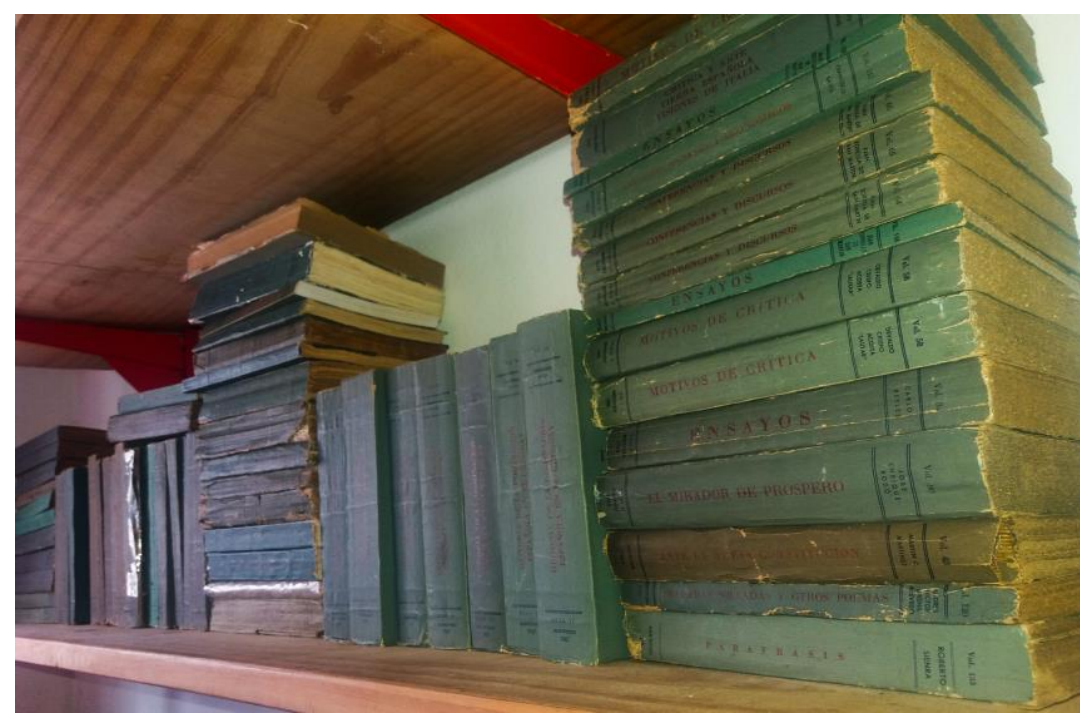

Algunos tomos de la Colección...

Tal como puede verse en las imágenes, la tapa tiene un orden establecido, que no cambió durante todo el período estudiado. ${ }^{148}$ En la parte superior, y en letras rojas mayúsculas, se lee el nombre con que fue bautizada la colección: «BIBLIOTECA ARTIGAS». Abajo, en color negro, con una fuente levemente mayor, se destaca: «COLECCION de CLASICOS URUGUAYOS [sic]». Así, todos los tomos se coronaron con el nombre del prócer uruguayo, subrayando el valor simbólico buscado en la confección de una colección con pretensiones de «canónica».

Le siguen, en línea descendente, otros datos: el número del volumen correspondiente —en arábigo - , el o los autor/es, y el título de la obra, resaltada en caracteres rojos, más grandes que los del resto de la tapa. Finalmente, el número de tomo, la ciudad de edición (que en todos los casos fue Montevideo), y el año. Así, se subrayaba tanto el nombre de la colección como el título del libro, concentrados ambos en la parte superior de la tapa.

En la Colección..., se pusieron los títulos originales de los textos, pero en el caso de la titulación de obras compiladas por los editores, se optó por la función descriptiva, del estilo: Escritos históricos, Obras pedagógicas, Escritos filosóficos y Polémica, entre otros modelos.

\footnotetext{
${ }^{148}$ Durante los años noventa, tuvo algunos cambios formales, pero desde la dirección de Wilfredo Penco —actualmente en el cargo — se ha vuelto a las características iniciales aquí desarrolladas.
} 
El destinatario del título, como recordara Genette (2001), es el público, que se diferencia respecto del lector, pues el público es «una entidad de derecho más vasta que la suma de sus lectores, porque engloba personas que no lo leen necesariamente o enteramente pero que participan de su difusión y, por lo tanto, de su "recepción”» (Genette, 2001, p. 67), como «el editor, su equipo de prensa, sus representantes, los libreros, los críticos y gacetilleros, y quizás, sobre todo, esos vendedores involuntarios» (Genette, 2001, p. 67). Por ende, el público excede la lista de los lectores. En este sentido, el título debe ser orientado al público, tratándose así de dos niveles diferentes de lectura y de destinatarios. Por eso el título se dirige a aquellas personas que pueden hacer circular el libro y no necesariamente a aquellos que lo van a leer.

Además, en la Colección... siempre se utilizaron los nombres reales de los autores, y no sus seudónimos, salvo en un solo caso, en donde se usaron comillas. ${ }^{149}$

Si la contratapa permanece vacía, en el lomo se repiten muchos datos de tapa: desde arriba hacia abajo, la abreviatura «Vol.» seguida del número correspondiente; el nombre del autor enmarcado en una doble raya; el título de la obra puesto de forma vertical y en caracteres rojos, y para terminar, nuevamente, una doble raya y debajo la ciudad de edición (Montevideo) y el año correspondiente. La ausencia de contratapa y de una solapa más elaborada - de hecho los libros no presentaron solapa - probablemente se vincule con el abaratamiento de los costos de la edición, ya que estos elementos probablemente hubieran hecho más complejo el proceso de impresión y encuadernación.

La escritura del título del lomo está hecha de forma ascendente, lo que conlleva algunos problemas ya que, si el libro se apoya en la contratapa, las letras quedan invertidas a la vista del espectador. Es por ello que entre algunos impresores y editores se utilizó el sentido inverso, o sea descendente, para una más sencilla lectura en la posición mencionada. Además, los libros posteriores a 1975 (año de creación del ISBN) no presentan dicho dato.

Al abrir cada volúmen, luego de una página de guarda, en blanco, la siguiente hoja posee el título de la obra, centrado y sin más información. En el reverso, los datos institucionales: encabezando la página, el escudo de Uruguay, con el nombre del Ministerio que lo editaba debajo. Luego, en mayúscula negrita, el nombre de la colección y la inscripción «Art. 14 de la Ley de 10 de agosto de 1950», que señalaba el origen estatal de su financiación e idea, subrayando el carácter oficial de la serie.

Más abajo, con el título «Comisión Editora», se detallaban los nombres de los cuatro integrantes con su pertenencia institucional, bajo lo cual se repetían los datos de la tapa, pero

${ }^{149} \mathrm{El}$ de Osvaldo Crispo Acosta «Lauxar», en los volúmenes 58 y 59 titulados Motivos de Crítica (1965). 
en otro orden: nombre de la colección, volumen, autor y título. Finalmente, se informaba qué institución o personas se habían hecho cargo de la preparación de los textos.

En la siguiente página, en la llamada portadilla, se insistía con el nombre del autor, el título (más grande que el resto), la ciudad de edición y el año. Sin embargo, aparecía un nuevo dato debajo del título: el nombre del prologuista. Esta indicación preparaba al lector para enfrentar el prólogo.

En la última página se incluía el colofón, donde se establecía la fecha en que se terminó de imprimir el libro y los talleres gráficos correspondientes en los que se realizó esta tarea.

\section{La impresión}

Durante el período estudiado, hubo tres etapas bien diferenciadas respecto a las empresas encargadas de la impresión. La primera, desde el inicio de la Colección... en 1953, y 1963, donde tres empresas se encargaron de llevar a la vida cada uno de los tomos; la segunda, un período monopólico que finalizaría en 1966 con Barreiro y Ramos como líder absoluto en la edición (y a un ritmo único en cantidad de tomos impresos), y la tercera, entre 1966 y 1982, en donde varias imprentas se hicieron cargo de estos trabajos encomendados por el Ministerio.

Respecto a la confección de los volúmenes, el 10 de agosto de 1951 fue iniciada una licitación que demostró que las firmas Enrique Bianchi Altuna, Impresora Uruguaya S.A. y Colombino S.A. presentaban los mejores precios, constatándose los siguientes valores por pliego respectivamente: $\$ 166, \$ 180$ y $\$ 183$. El de las dos primeras firmas presentó una composición de un $90 \%$ de pasta mecánica de pino, y la de Colombino fue de $50 \%$, «lo cual es el índice que asegura su mejor conservación y mayor consistencia». ${ }^{150}$

Por lo tanto, por más que las dos primeras tuvieran mejores precios, la calidad y precio de la última, «y el deseo de armonizar los precios cotizados con la impresión de la Biblioteca de autores clásicos en la forma más económica y a la vez más decorosa como corresponde el carácter de la colección a editarse; previa consulta a las firmas nacionales acerca de la uniformidad que debe caracterizar el trabajo a realizarse», ${ }^{151}$ llevó a que se decidieran en favor de Colombino S.A. Finalmente, se les adjudicó la impresión de la Colección..., por partes iguales, a las tres empresas, al «precio de 183 el pliego de diez y seis páginas en papel pluma segunda de $62 \mathrm{~g}$. por $\mathrm{m}^{2}$ cuya composición es $50 \%$ de pasta mecánica de pino y $50 \%$ de celulosa de pino, alisado y encolado, con caracteres al precio de $92 » .{ }^{152}$ Respecto a la

\footnotetext{
${ }^{150} \mathrm{AGNU}, 13$ de agosto de 1952, Colección Pivel Devoto, caja 128, carpeta 407b, fol. 3.

${ }^{151}$ Ídem.

152'́dem.
} 
composición formal, se «imprimirán como mínimo tres mil ejemplares en el formato de 12,5 por 19 centímetros, cuerpo de composición de 10/10, medida 18 y páginas de 16 líneas». ${ }^{153}$

Sin embargo, y a pesar del resultado de la licitación, no participaron las tres empresas por partes iguales como se había establecido. Colombino se hizo cargo de 16 volúmenes entre 1953 y 1961, mientras que Bianchi Altuna solamente imprimó tres durante los años 1953-1954. Únicamente la Impresora Uruguaya, que comenzó también en 1953, continuó imprimiendo hasta 1966, haciéndose cargo de 27 tomos en total.

Posteriormente, se hicieron nuevos llamados a licitación debido a la inflación, la mejora de los sueldos - gracias a los Consejos de Salarios-y el aumento de precios en el papel importado.

El 26 de junio de 1962 se autorizó a la Comisión a realizar un nuevo llamado a concurso para la impresión de las distintas obras de la Colección..., llegando hacia noviembre a una resolución. A dicho llamado se presentaron las impresoras que ya se encargaban del trabajo, como Colombino e Impresora Uruguaya, a las que se agregaron Barreiro y Ramos, Monteverde y Florensa y Lafón. La cotización que se pedía era por un pliego de 16 páginas más el resto de las características que ya presentaban los tomos desde 1953. La empresa ganadora fue Barreiro y Ramos, presentando un presupuesto muy ventajoso en términos económicos, ya que la diferencia con el resto fue muy amplia (por ejemplo, Colombino presentó un precio tres veces más caro). ${ }^{154}$

Barreiro comenzó a imprimir desde el volumen 37 (La epopeya de Artigas de Zorrilla de San Martín) de la Colección ... ${ }^{155}$ Cabe destacar que, durante el período estudiado, Barreiro se encargó de 98 tomos (1963-1981), lo que la convirtió en la impresora más importante de toda la serie.

Los datos relevados, incluyendo la cantidad de casas presentadas a licitación, dejan en claro la importancia del proyecto editorial, ya que imprimir tantos ejemplares por título, en un emprendimiento financiado con dinero estatal, era un buen negocio en términos absolutos. Las empresas presentadas eran las más grandes del mercado, con capacidad de resolver en tiempo y forma los pedidos. Además, poseían cierta solvencia económica como para sostener el pago atrasado de los trabajos, algo por demás común según se puede leer en los archivos oficiales. Hay que recordar que una queja constante se refería a la falta de continuidad con que el Estado resolvía sus responsabilidades, pero ante la recesión económica general, seguía siendo un buen negocio estar en correctos términos con las autoridades y percibir el beneficio de las grandes

\footnotetext{
${ }^{153}$ Ídem.

${ }^{154}$ AGNU, Ministerio de Instrucción Pública y Seguridad Social, caja 720, carp. 537.

${ }^{155}$ Ídem.
} 
tiradas que eran encomendadas por obra. Sin embargo, la crisis fue larga y dura para la industria editorial, lo que determinó algunos problemas en la resolución de los trabajos.

Hacia julio de 1965, y como consecuencia del aumento fenomenal que tuvo la producción de obras, la empresa Impresora Uruguaya manifestó su posibilidad de igualar el precio de Barreiro, y se comprometió a recibir trabajos para cumplir con la exigencia pedida por parte del ministro Pivel. Finalmente, se les otorgó la impresión de los tomos 75 y 76 (La recuperación del objeto de Joaquín Torres García) y se le prometió por lo menos nueve libros más con un promedio de trescientos páginas cada uno. ${ }^{156}$

Posteriormente, y en función de la coyuntura económica del Uruguay, ${ }^{157}$ bajo un llamado a licitación restringida, se resolvió, el 11 de mayo de 1966, que los nuevos impresores de la Colección... fueran tres: Barreiro y Ramos (la ganadora del concurso), y que cuando la intensidad fuera mucha, se le darían trabajos a Monteverde y a Impresora Uruguaya. Colombino no aceptó el bajo precio de Barreiro, y por eso dejó de imprimir. En consecuencia, Monteverde (quien ya imprimía el Archivo Artigas) hizo frente, durante dos meses, a trabajos encomendados por el Estado (entre diciembre de 1966 y enero de 1967), imprimiendo cinco volúmenes. La Impresora Uruguaya terminó cambiando de denominación al fusionarse con Colombino, y editando finalmente siete tomos más entre 1966 y 1975.

Durante la dictadura aparecieron nuevas impresoras en escena: Impresora Cordón (un tomo), Carlos Casales Impresores, y la Impresora Nacional (con dos tomos cada una), y finalmente Rex (con cuatro volúmenes).

A nivel físico, se pueden constatar algunas diferencias a simple vista. Como consecuencia de la variabilidad de empresas encargadas de la impresión, los tomos de Barreiro son más ásperos y opacos en sus tapas que los de Impresora Uruguaya, que tiene tapas más duras, lisas al tacto y brillantes. En cambio Monteverde, en los pocos volúmenes de los que se hizo cargo, aplicó una letra más fina en sus lomos y tapas.

Con respecto al papel, la calidad no era lo suficientemente buena, ya que la idea era abaratar el costo de los ejemplares, y hacer accesible a todos los ciudadanos las obras que se editaban. Esto, sumado a unas tapas de cartulina, eran la forma buscada para hacer los ejemplares más económicos, y acercarle al público masivo los libros difíciles de hallar e imposibles de reeditar — piénsese si no en la Historia de la dominación española ... de Bauzá, de seis tomos-.

\footnotetext{
${ }^{156}$ Ídem.

${ }^{157}$ Con inflación de más del $50 \%$ en el período 1963-1966, superada en 1967, ubicada en el récord histórico con $137 \%$ (Nahum, 2003), hacía imposible mantener los mismos valores. Además, el aumento de los salarios y el costo del papel a nivel internacional, con la subida del precio del dólar correspondiente, también jugaban en contra de mantener el precio.
} 


\section{La impresión bajo Pivel}

Durante los años cincuenta y sesenta, se constataron serias tardanzas en la entrega de los distintos tomos de la Colección..., ya que los pagos a las imprentas no se hicieron a su debido tiempo. En el archivo de Pivel se puede comprobar la situación reseñada (por ejemplo, cuando advierte que «Recién en el mes de julio las imprentas pudieron cobrar los libros entregados un año antes. Esta situación les había llevado a dar preferencia entre sus trabajos a las imprentas comerciales corrientes»). ${ }^{158}$ Por lo tanto, según expresaba el historiador nacional, el retraso en la edición de libros a veces se debía a lo espaciado de los pagos; antes que cumplir con un mal pagador — por más que fuera el Estado - y ante el riesgo a la desfinanciación, las empresas priorizaban el cumplimiento con los privados ya que pagaban en el momento.

Esto demuestra la ineficacia del Estado en la publicación de los volúmenes hacia la década del cincuenta, por falta de fondos. A raíz de dichos problemas, Pivel elevó sus quejas de manera sostenida, hasta que durante su estancia en el Ministerio, logró la inyección de una gran cantidad de dinero para terminar de conformar lo esencial de la serie.

Sin embargo, una vez al frente del Ministerio, Pivel fue muy crítico de los trabajos emprendidos por algunas de las firmas dedicadas a la impresión de los libros de la Colección... Cuando las obras impresas no contaban con su total beneplácito, se los hacía saber a través de duras misivas. Varias cartas atestiguan el descontento, por lo que se veía obligado a reclamar «un trabajo de mayor calidad del que viene realizando con la publicación e impresión de las obras que integran la Biblioteca Artigas». ${ }^{159}$

Por su parte, Pivel se preocupaba por que la calidad de las impresiones y encuadernaciones fuera buena, y si no se hacían en tiempo y forma, no dudaba en presionar a los impresores. En el caso de Barreiro, hasta se lo amenazó con dejar de enviarle trabajo y llamar a una nueva empresa. En carta de enero de 1965, Pivel manifestó que

...las dificultades ocurridas en el transcurso de los años 1963 y 1964 en la ejecución de los trabajos, la falta de cuidado puesta en los mismos, el atraso en la entrega, la pretensión de cobrar extraordinarios que no corresponden, impulsan al Ministerio en estos momentos a considerar la conveniencia de hacer un nuevo llamado a licitación para adjudicar la impresión de las publicaciones que efectúa, a establecimientos que tomen con más interés los trabajos que el Estado les encomienda. ${ }^{160}$

\footnotetext{
${ }^{158}$ AGNU, 15 de agosto de 1956, Colección Pivel Devoto, caja 128, carp. 407, fol. 3.

${ }^{159}$ AGNU, "Carta al Señor Gerente Industrial de la firma Barreiro y Ramos S.A. don Guzmán Barreiro", 5 de enero de 1965, Colección Pivel Devoto, caja 258, carp. 911.

${ }^{160}$ AGNU, Archivo Pivel Devoto, caja 254, carp. 894.
} 
Varios eran los motivos de la infelicidad del historiador ya que, como continuaba diciendo, «La calidad del papel es independiente de las irregularidades que se advierten en el doblado de los pliegos y en el cosido de la encuadernación». ${ }^{161}$ Es que anteriormente ya se le había avisado a Barreiro y Ramos sobre el

... desagrado por la falta de prolijidad que se advierte en el plegado y cosido de los ejemplares [...]. En el caso particular parece que ahora es el papel satinado que en la operación del doblado se corre y dá [sic] lugar a que los pliegos ofrezcan irregularidades, algunas de ellas realmente lamentables. ${ }^{162}$

A los problemas señalados, habría que sumar los que generaban la mala compaginación y la falta de papeles y cartulinas en el mercado. También se señalaban algunos de los detalles mínimos, como por ejemplo el hecho de que «el rojo de la carátula tiene un brillo excesivo, oportunamente indiqué que debía de ser un rojo opáco [sic]». ${ }^{163}$

La influencia directriz de Pivel se tradujo no solo en la compaginación e impresión de los tomos, sino también en otros aspectos del círculo de comunicación llevado adelante por la Colección..., como la distribución y la venta posterior.

\section{La distribución de los libros y su precio}

Luego de la impresión del libro y su respectivo encuadernado, era el momento de su distribución y venta. Esta última etapa del círculo de comunicación, previa a la compra por parte del consumidor, era de las más sensibles de todas. Sin una correcta distribución, el objeto-libro vería disminuida su posibilidad de llegada al público lector.

En el exterior, la venta era muy escasa y el margen de ganancias era tan bajo que no interesaba a ningún exportador. La suba de los precios de la impresión fue otro de los problemas remarcados. Por ejemplo, durante los años sesenta, y por tres años consecutivos - como consecuencia del aumento salarial proyectado por el Consejo de Salarios y la escalada del precio del dólar y del papel importado-, el costo del tomo aumentó un $35 \%$.

Finalmente, y si bien la calidad no era del todo buena, las ediciones eran cuidadas, pues no tenían erratas en exceso, porque la preparación de cada tomo era estrictamente controlada y llevaba su tiempo. La presión que le imponía Pivel al proceso era notoria, pues fiscalizaba

\footnotetext{
${ }^{161}$ Ídem.

${ }^{162}$ AGNU, "Carta al Señor Gerente Industrial de la firma Barreiro y Ramos S.A. don Guzmán Barreiro", 5 de enero de 1965, Colección Pivel Devoto, caja 258, carp. 911.

${ }^{163}$ Ídem.
} 
personalmente cada una de las obras listas para ser impresas, basándose además en su propia experiencia. ${ }^{164}$

Con respecto al precio, la Colección... fue pensada para llegar a toda la población con un valor de \$1,5 por ejemplar, mientras los libros nacionales costaban entre \$ 3 y \$4, según los valores de los primeros años de la década del cincuenta. ${ }^{165}$ Sin duda, el cometido del Estado era permitir el acceso de todos sus habitantes a los tomos presentados, ya que tanto el precio como la cantidad de ejemplares impresos — entre tres mil y seis mil— se orientaban hacia tal objetivo.

Pivel declaraba que la meta de la Colección ... era «reunir [en] un cuerpo seriado, más o menos sistemático, la expresión cultural del país, en cuyo propósito el estado no debe perseguir interés alguno de lucro». ${ }^{166}$ No solo no había interés en tener ganancias con la publicación de los tomos, sino que se iba a pérdida, según consta en los registros que llevaba la Biblioteca Nacional. ${ }^{167}$ Eso no solo se debía al bajo precio de los libros, sino también a la gran cantidad de descuentos que existían para hacerse con ellos, según veremos más adelante. Lógicamente, la idea era que los tomos estuvieran a disposición de la mayor cantidad de público posible. Por otra parte, Pivel agregó que

\begin{abstract}
... no quiere decir que estos ejemplares se regalen, hay que acostumbrar al público a que compre las obras editadas por el Estado, quien vende a bajos precios, pero no excesivamente. Además, el bajo precio de venta desinteresa a los libreros y dificulta la difusión por los distribuidores en el extranjero. ${ }^{168}$
\end{abstract}

En este caso, Pivel ya actuaba como un editor, al pensar en el mercado librero y conocer su funcionamiento. El objetivo nunca fue que solo el Estado comercializara la Colección..., pues se necesitaba a los vendedores privados para una mejor distribución y llegada.

\title{
La distribución y la venta
}

El circuito que seguía el libro que producía el Estado tenía como objetivo llegar a manos del más diverso público posible dentro del Uruguay, y también a otros países de la región y el mundo. Para ello, era necesaria una muy buena distribución.

\footnotetext{
${ }^{164}$ Como vimos en el capítulo 3, en sus años jóvenes se había dedicado a ser corrector de imprenta (Vidaurreta, 2001).

${ }^{165}$ Según se pudo constatar observando las boletas de cobro de las distintas impresoras, y la cantidad de ejemplares impresos, el Estado perdía, durante los años cincuenta, un promedio de $\$ 0,2$ por tomo vendido.

${ }^{166}$ AGNU, Colección Pivel Devoto, caja 128, carp. 407, fol. 94.

${ }^{167}$ AGNU, Ministerio de Instrucción Pública y Seguridad Social, caja 589, carp. 3138.

${ }^{168}$ AGNU, Colección Pivel Devoto, caja 128, carp. 407, fol. 94.
} 
Inicialmente, la administración de los libros la realizaba la Biblioteca Nacional. Dicha institución se quedaba con doscientos ejemplares para armar colecciones en su repositorio y canjear con bibliotecas de otros países; el resto los vendía, obteniendo recursos para su funcionamiento. Además, estaba encargada de pasar de manera semestral un detalle de lo vendido y de lo que quedaba en depósito. También se le entregaba parte de los ejemplares a un particular, Héctor D’Elía, quien ya tenía experiencia en el negocio de la distribución y poseía contactos en América y Europa. Además, D’Elía estaba vinculado a la revista de Susana Soca Entregas de La Licorne, lo que le daba cierto reconocimiento en el medio literario uruguayo. ${ }^{169}$

Posteriormente, desde la mitad de los años sesenta, quien se hizo responsable de la distribución fue el Instituto del Libro, ${ }^{170}$ convocando a su vez a otras distribuidoras, para la circulación interna y externa de la Colección... De esta manera, el Ministerio se desligaba de uno de los mayores problemas que tenía, sobre todo con el depósito y reparto del stock. ${ }^{171} \mathrm{~A}$ esto hay que sumarle la participación de la imprenta más importante del período de oro, Barreiro y Ramos, que también asumió la distribución. Allí, los talleres gráficos, que ocupaban una manzana entera del barrio Sayago en Montevideo, tenían una excelente capacidad de almacenamiento, lo que implicaba una importante disponibilidad de espacio para su depósito.

El arreglo económico al que tenían que llegar era vender cada tomo con un $50 \%$ de descuento para los distribuidores, y de 30 \% para las librerías. Los libros serían retirados del Instituto o de las imprentas que se encargaban de imprimirlos, y el mínimo de adquisición era de trescientos ejemplares por título. El precio final tenía que ser el que fijara el Ministerio para todos los tomos, con las actualizaciones que considerara pertinentes. Los distribuidores debían contar con una demostrada capacidad de entrega en todo el país y el exterior. ${ }^{172}$

También existía un sistema de suscripción. Los suscriptores tenían $30 \%$ de descuento en cada libro y tenían la obligatoriedad de comprar todos los tomos que salieran desde el momento en que se anotaran.

Los puestos oficiales de expendio, durante todo el período, estuvieron ubicados en la Biblioteca Nacional y en el Instituto, donde además se estableció la necesidad de que se hiciera publicidad oficial para fomentar las ventas. ${ }^{173}$

Sin embargo, los problemas en la distribución no se pudieron resolver. En diciembre de 1965, Pivel le escribió al gerente de Barreiro y Ramos, que se había comprometido a distribuir tomos de la Colección..., y le comunicó que

\footnotetext{
${ }^{169}$ AGNU, Ministerio de Instrucción Pública y Seguridad Social, caja 589, carp. 3138.

${ }^{170} \mathrm{El}$ Instituto fue fundado en 1964 como consecuencia de la Ley 13318.

${ }^{171}$ AGNU, Ministerio de Instrucción Pública y Seguridad Social, caja 589, carp. 3138.

${ }^{172}$ Ídem.

${ }^{173}$ Ídem.
} 
...como la última entrega efectuada hace un mes aún no ha sido repartida, interpretamos este hecho como una manifestación de la Casa Barreiro en el sentido de que no tiene ya el propósito de continuar cooperando con el Ministerio en la obra mencionada. En consecuencia solicitamos a la Casa Barreiro la devolución de los ejemplares que tiene en su poder, debiendo comunicarnos previamente la fecha en que nos la remitirá. ${ }^{174}$

Nuevamente, la influencia directriz de Pivel estaba encarnada en la celosa custodia de los intereses del proyecto cultural. Además de pedir la devolución de los libros, la misiva también funcionaba como advertencia para próximos casos en que pudiera existir algún tipo de inconveniente, y que probablemente repercutiría de forma más severa en los intereses comerciales de Barreiro y Ramos.

Con respecto a la recepción de las obras, se hace muy difícil en una serie tan extensa en tomos y años poder seguir el rastro de cada uno de ellos. La documentación que nos ha llegado hasta el día de hoy es incompleta y dispar, pues en algunos años, se señalaba el número de ejemplares vendidos y, en otros, la cantidad de dinero que entraba. En la actualidad, el Estado tiene a la venta algunos ejemplares que fueron reeditados entre los años sesenta y ochenta, ${ }^{175}$ además de aquellos tomos de reciente aparición. Por lo tanto, los volúmenes impresos durante los años estudiados se encuentran agotados en las órbitas estatales.

Los libros tenían, como destino inicial, el público en general y las instituciones educativas públicas y privadas, además de habituales envíos al exterior con motivo de difundir la cultura letrada del país.

Durante los primeros años de la década del cincuenta, los ejemplares salidos a la venta se agotaron casi en su totalidad. Además, podemos destacar que, durante el primer año, según consta en un informe presentado por el Ministro Zavala Muniz, se vendieron 10.850 ejemplares de un total de 18.000 editados, lo que para el medio nacional era un número muy grande. ${ }^{176} \mathrm{El}$ éxito inicial tenía que ver con la novedad de los libros editados por el Estado, y con la poca cantidad de autores nacionales que aparecían en el mercado debido a la crisis editorial que había en Uruguay, y que fue motivo de reflexión de diversos intelectuales, mayoritariamente nucleados en Marcha.

\footnotetext{
${ }^{174}$ AGNU, Archivo Pivel Devoto, caja 254, carp. 894.

${ }^{175}$ Se reeditaron: Ismael de Acevedo Díaz (editado en 1953 y reeditado en 1985); Descripción Geográfica del Territorio de la República Oriental del Uruguay de Reyes (1953 y 1960); Montevideo Antiguo de De María (1957 y 1976); Arte, estética e ideal de Figari (1960 y 1988); Antología de Agustini (1965 y 1986); Obras poéticas de Herrera y Reissig (1966 y 1976); y Teatro de Sánchez (1967 y 1975).

${ }^{176}$ AGNU, Ministerio de Instrucción Pública y Seguridad Social, caja 589, carp. 3138.
} 
Según el artículo 4 del Decreto reglamentario de la ley que creó la Colección..., la Biblioteca Nacional era la encargada de notificar respecto del movimiento de las obras, quedándose con el dinero recaudado para sus cuestiones internas —aunque hacia 1963 se comenzó a depositar en la cuenta 2.07 del Banco República a nombre del Ministerio—. ${ }^{177}$

Por otro lado, y en oficio del 2 de agosto de 1966, la dureza de la crisis y la inflación, hicieron que el Ministerio tuviera que enviar una nueva partida de dinero a las instituciones encargadas de editar publicaciones nacionales y oficiales, ${ }^{178}$ ya que los costos de la impresión obligaban a tal determinación. Dentro de la justificación, se puede leer que

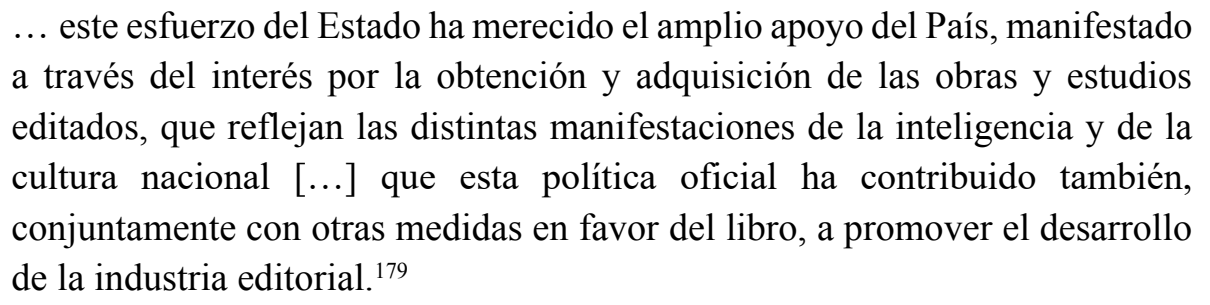

Por tanto, se consideraba de manera oficial que las obras editadas por el Estado no solo estaban teniendo éxito, sino que también, sumándose a las políticas implementadas durante el período, habían ayudado al resurgimiento del mercado editorial.

Respecto de la distribución en Latinoamérica, según se recoge en la documentación, se hacía muy difícil llevar adelante esto, ya que era muy complejo cobrar los libros que eran enviados, por lo que se suspendió la entrega. ${ }^{180}$

\section{Los derechos de autor}

Otro de los temas fundamentales para conocer qué había detrás de escena del proceso editor, son los derechos de autor. Según consta en la variada documentación del Ministerio, era algo habitual obviar el tema. La comisión no veía que los derechos de autor fueran un escollo para la edición, y se pudo constatar que, a medida que empezaron a llegar algunos reclamos, se llevó adelante una estrategia pragmática para resolver los problemas.

Solo en tres casos se presentaron denuncias contra el Ministerio por el no pago de derechos, y en esos casos los reclamos fueron hechos por los herederos de los autores y familiares. Así, por ejemplo, en 1966, la única heredera de Osvaldo Crispo Acosta (muerto en

\footnotetext{
${ }^{177}$ Ídem.

${ }^{178}$ En este caso al que hacemos mención, se destinaron $\$ 2.250 .000$.

${ }^{179}$ AGNU, Archivo Pivel Devoto, caja 254, carp. 894.

${ }^{180}$ AGNU, Ministerio de Instrucción Pública y Seguridad Social, caja 589, carp. 3138.
} 
1962) solicitó al Ministerio que se le abonaran los derechos de autor por la obra Motivos de crítica (1965), impresa por la Colección ... en cuatro tomos. ${ }^{181}$

La reglamentación vigente, durante el desarrollo de los casos citados, establecía que el derecho de propiedad de las obras era mantenido por los herederos por un plazo de cuarenta años desde el día del deceso del autor. ${ }^{182}$ Según la Oficina de Registro de Derechos de Autor, el pago que se debía efectuar tendría que ser del $10 \%$ sobre el total del tiraje hecho por la Colección...

A un promedio de tres mil ejemplares por tomo, el monto total supuso un importante desembolso estatal. ${ }^{183}$ Este fue el primer caso que se le presentó a la Comisión con respecto a reclamos por derechos de autor, algo muy poco extendido en la época. Resulta extraño que por la edición de muchas de las obras que tenía el catálogo, no se hubieran generado otros litigios de ese tipo.

Seis meses después, surgieron nuevos conflictos con los herederos de Romildo Risso y de Carlos Reyles, ${ }^{184}$ y la resolución fue la misma que con lo sucedido con Crispo Acosta.

\section{Conclusiones parciales}

El estudio de la forma material y física del libro pone en evidencia los rasgos que fueron buscados, desde la órbita estatal, para darle ciertas características al proyecto impulsado, dando cuenta del tipo de lector pretendido y el perfil buscado para la publicación.

Primeramente, la sobriedad de su conformación exterior vuelve tangible la solemnidad con que se pensaba consolidar la nacionalidad uruguaya, desde el punto de vista cultural, entre los lectores. La preocupación por mantener las características físicas, y los estándares de una cierta calidad a bajo precio, se vuelven evidentes en la documentación disponible. En efecto, como editor central, Pivel pretendió asegurar el proyecto estatal a través de una calidad reconocible interna y externa, pero de bajo costo para alcanzar al mayor número posible de lectores. Sin embargo, el mismo desarrollo en el tiempo generó diverso tipo de problemas, como por ejemplo la distribución y venta de los ejemplares. El bajo precio de los libros, y por tanto, el bajo monto de las ganancias, implicaron que los libreros muchas veces ignoraran la salida de los tomos.

\footnotetext{
${ }^{181}$ AGNU, Ministerio de Instrucción Pública y Seguridad Social, caja 720, carp. 537.

${ }^{182}$ Según consta en Ley 9739 de 1937.

${ }^{183}$ En total se pagaron $\$ 18.000$ por derecho de autor de la obra de Crispo Acosta.

${ }^{184}$ AGNU, Ministerio de Instrucción Pública y Seguridad Social, caja 720, carp. 537.
} 
Por otro lado, con respecto a los derechos de autor, el Estado no se ocupó de las posibles problemáticas que se le podrían presentar al editar a autores sin autorización; por ende, los únicos pagos realizados fueron por las intimaciones presentadas por parte de los descendientes.

Al abrir un ejemplar de la Colección..., y ya observado sus condiciones físicas, nos encontramos con su respectivo prólogo, en el próximo capítulo, lo analizaremos para completar la caracterización emprendida. 


\title{
CAPÍtULO 5
}

\section{LOS PRÓlOGOS DE LA COLECCIÓN...}

"Dios te libre, lector, de prólogos largos." Francisco de Quevedo, «Al lector...» en El mundo por de dentro.

Nadie está obligado a leer el prólogo de un libro, pero lo cierto es que allí está. Puede contener breves referencias biográficas del autor, características de la obra que se leerá, o comentarios eruditos de un crítico prestigioso, pero el lector siempre decidirá qué hacer con ese umbral que lo llevará al texto central. Desde una tímida hoja hasta 650 páginas de densas consideraciones, los estudios previos a la obra son una parte esencial de los artefactos de conducción de lectura.

Como sabemos, durante todo el período estudiado, la serie de libros editados por el Estado impulsó su canon de autores uruguayos y se vanaglorió de la calidad de sus prologuistas.

Consideramos que, en el caso de los prólogos «Más que de un límite o de una frontera cerrada, se trata aquí de un umbral o — según Borges, a propósito de un prefacio-, de un "vestíbulo" que ofrece a quien sea la posibilidad de entrar o retroceder» (Genette, 2001, p. 7). Si esa antesala al texto se nos presenta como un contenido esencial de la edición estatal, pretenderemos en este capítulo centrarnos en su interpretación.

El prólogo corre con la ventaja de estar presentado antes que la obra propiamente dicha, pero, en cambio, tiene la desventaja de haber sido escrito después de ésta, lo que supone, en palabras de Derrida (1997), la producción de un artefacto exterior a ella.

El autor francés decía que

\begin{abstract}
...para el prólogo, que vuelve a formar un querer-decir a cosa hecha, el texto es un escrito - un pasado - que, en una falsa apariencia de presente, un autor oculto y todopoderoso, con pleno dominio de su producto, presenta al lector como futuro suyo. Esto es lo que he escrito, después leído y que escribo que van ustedes a leer. Después de lo cual podrán ustedes tomar posesión de este prefacio, que en suma ahora no leen, aunque, habiéndolo leído, ya se hayan anticipado a todo lo que le sigue y pueden casi dispensarse de leerlo. El pre del prefacio hace presente el porvenir, lo representa, lo aproxima, lo aspira y adelantándolo lo pone delante. Lo reduce a la forma de presencia manifiesta (Derrida, 1997, pp. 12-13).
\end{abstract}

Por tanto, la importancia de este dispositivo de control de lectura radica no solo en la conducción de aquello que a posteriori se va a leer, sino también en su capacidad de reducir un texto de manera manifiesta, según los intereses del prologuista. El prólogo se situaría en un no tiempo que flotaría por todo el texto, actualizándolo en función del tiempo del lector. 
Genette estudia la relación y el intercambio entre el texto y el paratexto, donde el lector es espectador y a la vez destinatario de dicha transacción de significados, clasificando detalladamente cada tipo de vínculo entre ellos (2001, p. 8). En consecuencia, para facilitar nuestro enfoque teórico respecto de los estudios preliminares al texto, podríamos apoyarnos en la clasificación desarrollada por el crítico francés, considerando algunos puntos. Así podremos evaluar mejor las operaciones críticas implícitas en los prólogos escritos por los distintos historiadores, literatos e intelectuales convocados por la comisión editora de la Colección...

Teniendo en cuenta el estudio llevado adelante por Genette, creemos que los prólogos de la serie estudiada ingresan dentro del tipo conocido como "prefacio alógrafo". Esta categoría hace referencia a los prólogos que tienen como cometido establecer una correcta (y por ende, dirigida) interpretación del texto. Sin embargo, esta dirección de la lectura depende justamente de que el prólogo sea leído, lo que determina necesariamente la efectividad del dispositivo en una primera instancia (Genette, 2001, p. 168). Posteriormente, y si dicho escollo es superado, es imperioso que el sentido del prefacio sea el adecuado, y que recomiende diferentes miradas al texto posterior e informe sobre el autor o la obra que se presenta. ${ }^{185}$ El prologuista introduce algunas interpretaciones necesarias del texto, ya que está interesado en el enfoque "adecuado" del lector. También puede justificar por qué vale la pena leer el libro. Genette destaca que generalmente los autores pretenden engrandecer los textos sin hacer referencia a su propio trabajo:
Valorizar el texto sin (parecer) valorizar a su autor implica algunos sacrificios dolorosos del amor propio, pero generalmente rentables. Evitamos por ejemplo insistir en lo que podría pasar por una puesta en evidencia del talento del autor (Genette, 2001, p. 169).

Sin embargo, en el caso de los redactores de los estudios previos a las obras, estas alabanzas generalmente son explícitas. Los prefacistas suelen recomendar los textos apoyándose en su prestigio simbólico. Los autores de prefacios apelan a la originalidad del texto para resaltar el valor de lo editado.

Como dijimos, el prefacio puede informar sobre la génesis de la obra, las circunstancias de su redacción y las distintas etapas posteriores. En el caso que nos ocupa, el prologuista se valió especialmente del recurso clásico de la amplificatio o auxesis, propia de los oradores de la Antigüedad, que servía para resaltar la importancia del tema o del libro que se editaba.

\footnotetext{
${ }^{185}$ En la Colección..., se informaba sobre el origen de la obra, haciendo consideraciones eruditas sobre la primera edición, correcciones, editoriales que se hubieran encargado del texto, entre otras referencias. Con relación al autor, mayoritariamente se presentaba una pequeña biografía que destacaba algunos acontecimientos de su vida, con directa significación respecto del texto que se estaba prologando.
} 
En este capítulo nos ceñiremos al caso de Pivel, uno de los prologuistas más fecundos que tuvo la Colección... — no solo por su talla intelectual sino también por su participación dentro del proyecto editorial—, en donde observamos que, cómo prologuista, buscaba dirigir al lector. En sus estudios previos, Pivel desarrollaba una lectura que debía ser asumida acríticamente por parte del lector. Parafraseando a Umberto Eco (1992), se buscaba hacer una lectura de la obra que fuera lo más cerrada posible. Particularmente en su discurso, plagado de referencias eruditas mayoritariamente de documentos y posturas historiográficas, expresaba su opinión a través de las posturas de otros, interpretando las fuentes a su conveniencia. Lo compacto y homogéneo de su relato pretendía encajar en su proyecto historiográfico. El Pivel editor entendía que los sentidos de las obras prologadas debían ser controlados desde los estudios previos, que poseían un doble componente simbólico, ya que eran editados por el Estado nacional y redactadas por importantes y reconocidos intelectuales.

El prólogo se presentaba entonces como un espacio de dominio interpretativo y editorial, que representaba cabalmente el proyecto estatal oficialista; y tanto los prologuistas como los editores eran conscientes de ello.

Si nos enfocamos directamente en la Colección ..., la preocupación por los prólogos, como dispositivos de control y direccionamiento de lectura, hizo que la comisión editora pusiera, en manos de los críticos más importantes del país, la confección de cada uno de los estudios previos.

Ahora bien; no era lo mismo desarrollar la actividad crítica en ámbitos privados que bajo el control estatal, sobre todo durante el Ministerio de Pivel. Por ende, tal como veremos en el capítulo 7, creemos que en general hubo auto-censura en la confección de los prólogos, y que los textos que no contenían lo esperado por Pivel finalmente no fueron editados. ${ }^{186}$

Como dijimos, aquí nos proponemos estudiar los prólogos escritos por Pivel entre 1957 y 1981, cuando actuó como director de la Colección ..., cumpliendo además los roles de editor, historiador y administrador estatal. Para ello, entendemos que existieron tres períodos claramente diferenciados en los que vamos a separar nuestro estudio. ${ }^{187}$ En primer término, aquellos ofrecidos en los años cincuenta a instancias de la comisión editora (dos prólogos para libros de José María Reyes en 1953, y de Isidoro De María en 1957). Luego, los realizados

\footnotetext{
${ }^{186}$ Para un desarrollo más detallado de estos casos ver el Capítulo 7.

${ }^{187}$ Como dijimos, fueron 12 volúmenes, que sumaron 1143 páginas. Si bien el promedio resulta bastante alto ( 95 páginas), existieron dos obras que modificaron el caudal de producción escrita por Pivel, y son los tomos dedicados a Bauzá (un prólogo de 679 páginas y otro de 154). Si los quitáramos de la lista, el promedio pasaría a 31 páginas, una cifra más cercana a la mayoría de los prólogos.
} 
durante su estancia como Ministro, entre 1963 y 1967, que suponen la mayoría no solo de su obra como prologuista, sino también de la base historiográfica de la Colección... (seis: para Mateo Magariños Cervantes y Juan Zorrilla de San Martín en 1963, para Francisco Bauzá y Juan Manuel de la Sota en 1965, y para dos tomos sobre Bernardo Prudencio Berro en 1966). Y finalmente, los elaborados durante el período 1968-1981, en los años del autoritarismo estatal (cuatro: para César Díaz en 1968, uno para Bauzá en 1972, otro para una recopilación de artículos en 1975, y de Luciano Lira en 1981).

En los primeros prólogos hechos por Pivel, se estableció una marca distintiva a nivel de la estructura argumental sobre cómo debían ser los demás estudios previos bajo su dirección. La fórmula debía contar con algunos ingredientes básicos, a saber: datos biográficos del autor (o autores), fuentes en las que se basaba para diagramar el texto - en caso de no tratarse de una fuente ficcional-, historicidad de la obra - tanto su primera edición como aspectos relacionados con el financiamiento o cambios formales en ediciones posteriores-, reseña de lo que se publicaba en el tomo prologado y, finalmente, la justificación e importancia de lo impreso para consolidar el nacionalismo uruguayo.

La mayoría de los prólogos de obras historiográficas publicadas por el Estado fueron hechas por Pivel. En total, el historiador nacional se hizo cargo de doce prólogos, y le siguieron en las preferencias (con dos prólogos cada uno) Eustaquio Tomé y Raúl Montero Bustamente. ${ }^{188}$

A nivel general, observamos un elemento en común entre todas las obras editadas por la Colección... Pareciera que, desde el punto de vista de Pivel, cada libro seleccionado representaba las bases de formación y posterior desarrollo de la conciencia nacional. Sin embargo, también existen marcadas justificaciones autobiográficas, ya que muchos de los autores — como el caso de Bauzá- fueron trascendentes en la vida académica del propio Pivel. ${ }^{189}$

Si bien hay obras de otras disciplinas, la Historia predomina en la lista, dada su relevancia para la consolidación de la nación. Recordemos que, antes de hacerse cargo de las distintas instituciones públicas en donde tuvo fuerte participación, Pivel comenzó su carrera intelectual como historiador, labor que no abandonó nunca, pero que por momentos pareció dejar de lado.

\section{Adelantando el proyecto editorial}

\footnotetext{
${ }^{188}$ En el caso de Montero Bustamente, hablamos de prólogos agregados en los volúmenes de manera póstuma en 1923 (tomo 152) y 1936 (tomo 149). Respecto a Tomé, integraba las redes intelectuales pivelianas.

${ }^{189}$ Ver el Capítulo 3.
} 
Durante los años cincuenta, el catálogo de la serie de libros fue marcado firmemente por los gobiernos colorados y sus ministros de Instrucción Pública. Como vimos, durante el primer año de edición, el Estado se despachó con 11 volúmenes de la nueva colección. Luego, si bien el número de volúmenes fue descendiendo debido a varios problemas, igual terminaron publicándose 28 tomos en cinco años.

La Comisión, presidida por ministros colorados, eligió a autores especialistas en los escritores editados, y a los intelectuales cercanos a los puntos de vista históricos y literarios que favorecieran un discurso homogéneo sobre la nación uruguaya. Luis Bonavita, Carlos Vaz Ferreira, Roberto Ibáñez, José Pereira Rodríguez, Alfredo Castellanos y Ángel Rama fueron los elegidos para desarrollar sus estudios críticos en los primeros seis tomos.

Sin embargo, en ese grupo de selectos críticos se encontraba Pivel. ¿Cómo podía suceder que un historiador vinculado al Partido Nacional estuviera en la primera nómina de prologuistas? Pivel integraba la Comisión debido a su puesto como director del MHN. Además, por su función intelectual, era dueño de un relato historiográfico neutro que pretendía unificar a los partidos políticos tradicionales, aspecto que resultaba funcional a los dos bandos políticos, amén de que, por este motivo, su nombre no generaba discusiones. Por ello ingresó rápidamente en la nómina de prologuistas. Sin embargo, inicialmente no se lo convocó para prologar una obra histórica, sino para un tratado de geografía.

En efecto, el primer prólogo encargado a Pivel, en la Colección..., fue Descripción Geográfica del Territorio de la República Oriental del Uruguay, de José María Reyes ${ }^{190}$ (1953). Nuestra hipótesis es que este prólogo contiene los principales rasgos del proyecto editorial pergeñado por Pivel, que pudo concretarse gracias a su posterior derrotero administrativo y político, que lo llevó además a convertirse en director de toda la Colección...

En ese prólogo, Pivel pretendió estudiar detalladamente la biografía de Reyes. Comenzó señalando su militancia inicial junto al ejército patriota, y posteriormente al de Manuel Oribe, como forma de demostrar que Reyes era un autor comprometido con su tiempo y su patria — aunque también con el Partido Nacional—. Luego Pivel señaló las fuentes en las que se basó el autor para la construcción de la obra, apuntando a demostrar la importancia científica del volumen que se estaba editando.

\footnotetext{
${ }^{190}$ José María Reyes (1803-1864), nacido en San Marcos (Córdoba), integró una familia de funcionarios del Gobierno Real de la Provincia. Estudió en Buenos Aires y desarrolló tareas como topógrafo en el ejército revolucionario. Una vez independizado Uruguay, creó el primer departamento topográfico del país. Fue funcionario del nuevo gobierno y actuó además como secretario del primer presidente Fructuoso Rivera, aunque durante la Guerra Grande estuvo junto a Manuel Oribe. Fue protagonista de la conformación de los nuevos límites entre Uruguay y Brasil en 1852, designado como comisario de la República. Murió en Montevideo en 1864 (Pivel, 1953).
} 
Finalmente, Pivel se valió del espacio dado por el Estado para exponer una lista justificada de aquellos autores que consideraba necesario editar y que, como sabemos, durante su estancia en el Ministerio logró concretar:

La obra de Reyes debe ubicarse en el plano en que la valoración histórica ha colocado el esfuerzo de los hombres de pensamiento que contribuyeron a definir y a asentar en la conciencia colectiva los rasgos del carácter nacional. Larrañaga y Pérez Castellano, con sus estudios augurales; Bauzá, con el gran cuadro de la formación histórica; Zorrilla de San Martín, que dió formas definitivas a un sentimiento todavía disperso; Blanes, que recogió en su paleta el color de nuestra tierra y la imagen de su época heroica; Acevedo Díaz, que perfiló los rasgos de los personajes que la animaron; José María Reyes, que nos dio con fundamento científico la visión física del Uruguay, el primer inventario y arroyos, sierras, valles y colinas, pueblos y ciudades, con orgánico de sus ríos sus árboles y sus flores y sus nombres indígenas y tradicionales, la ida, embellecida con su pupila de artista, del mundo geográfico donde alienta la nacionalidad oriental que debe reconocerle como a uno de sus forjadores (Pivel, 1953, p. 36).

En el inicio de la cita, Pivel enaltecía la obra de Reyes, ubicándola en el mismo plano que a los otros mencionados. Era coherente que el prologuista insistiera en la importancia de un estudio sobre la geografía de un país que no poseía límites. La necesidad de dar cohesión a un territorio que aún no era controlado por el gobierno nacional cumplía la tarea de ubicar en el imaginario social la unidad todavía no conseguida. El intento de Reyes se inscribía en las búsquedas posteriores que llevarán fundamentalmente a historiadores y literatos a dar nacimiento al sentimiento nacional. Por lo tanto, Pivel señalaba la necesidad de introducirlo en esa nómina junto a otros grandes nombres ya conocidos. Podemos considerar que los gestores del panteón intelectual fueron los autores de la valoración histórica. Sin embargo, no sabemos quiénes eran ni cómo estaría integrada dicha lista. Nos parece fundamental detenernos momentáneamente en este problema.

Debemos señalar la singularidad de la cita, ya que en toda la historia editorial del Uruguay el Estado nunca se había abocado a generar un canon de escritores sobre los que se construyeran los cimientos historiográficos, científicos y literarios del país. ${ }^{191}$ El carácter pionero de la colección oficial marcaba la urgencia por determinar a los autores merecedores de tal destaque, y es allí donde aparecía esta lista justificada por Pivel.

Inicialmente, como señala Pivel en su cita, toda la obra de Reyes suponía una unidad editable. Ahora bien, dentro de esa unidad estaba la singularidad, ya que solo se editaba el

\footnotetext{
${ }^{191}$ Se podrá objetar que el Estado sí había gestado algunos lineamientos previos con los programas escolares, liceales y universitarios, pero lo cierto es que nada tiene que ver con la historia de la edición, ya que nunca fueron editados de manera coherente y con estudios críticos.
} 
estudio geográfico al que hicimos mención. Entonces, entendemos que existió una selección necesaria mediante la que se separó aquello que sirvió a la Colección... para forjar las bases geográficas de la nación, desechando aquellos estudios menores del mismo autor, que se consideraron intrascendentes a fin de llevar a cabo el proyecto editorial. Si se debe poner a Reyes dentro de la selección de "hombres de pensamiento" (¿intelectuales?) que dieron forma al Uruguay, rescatarlo del olvido es también olvidar otros aspectos de su persona y de su obra que no le parecía significativo incluir en su prólogo.

Entonces, siguiendo con la lógica planteada por Pivel en el fragmento antes citado, la obra de Reyes debía ser colocada junto a otras que ya estaban en un lugar donde la "valoración histórica" las puso. Este nuevo término parece designar algo importante y definitivo, pero lo cierto es que dicha "valoración" no existía o, por lo menos, era un concepto demasiado vago e impreciso. Si fue la Historia la que estableció una serie de obras fundamentales para el Uruguay, deberíamos preguntarnos a cuáles se refiere y quién o quiénes las seleccionaron. Quizás la respuesta no estuviera tan lejos, y más que una lista de libros o autores la llave fuera el firmante de este prólogo: Pivel.

Los escritores que definieron y que asentaron la conciencia colectiva de lo que era el Uruguay fueron aquellos identificados como tales por parte de Pivel. El historiador nacional consideraba que existieron históricamente algunos hombres a los que se les debió reconocer tal mérito, y era la Colección... la que tenía que rendir su justo homenaje. La conformación de un canon oficial era la propuesta que debía tener el Estado, y Pivel estaba allí para hacerla cumplir. En consecuencia, en los prólogos llevó a cabo la justificación de dichos nombres canónicos, dirigiendo las miradas para explicar la razón de ser de las obras en el contexto nacional. Cada uno de los autores que se mencionaban en la cita, como dijimos, fueron editados por Pivel durante su estancia en el Ministerio. Lo que de alguna manera reafirmaba que los nombres que se manejaron no fueron improvisados, sino que formaban parte de una interpretación piveliana de la vida intelectual nacional y en la serie editada por el Estado encontró el recinto donde poder "rescatar del olvido" a los escritores que consideraba fundamentales.

Estudiemos los nombres mencionados en la cita precedente, teniendo en cuenta que el único que no fue editado fue el pintor Juan Manuel Blanes. ${ }^{192}$ Primeramente, Pivel mencionó a dos autores como dueños de "estudios augurales". La terminología los dejaría exentos de precisiones con respecto al nacimiento de la nacionalidad, ya que por su lejanía cronológica no serían culpables de algunos errores conceptuales y de falta de conocimiento histórico, ya que

\footnotetext{
${ }^{192}$ En la Colección... se editaron solamente textos. Para el caso de Blanes no se publicó ningún trabajo vinculado con su obra no pictórica.
} 
nada se había escrito aún sobre el tema. ${ }^{193}$ El primer nombre que mencionó fue el del sacerdote Dámaso Antonio Larrañaga quien, además de ser el fundador de la Biblioteca Nacional, ${ }^{194}$ fue un intelectual fundamental de principios del siglo XIX. En 1965, durante el Ministerio de Pivel, se publicó una Selección de Escritos (vol. 92). El libro contaba con una recopilación de cartas, diarios de viajes, informes, fábulas y proyectos de ley presentados ante el primer Senado de la República.

El segundo nombre citado fue el de otro sacerdote intelectual presente en la revolución oriental: Juan Manuel Pérez Castellanos. Este autor fue publicado en los volúmenes 130 al 132 con otra Selección de Escritos (1968), vinculados a las crónicas históricas del período 17871814 y a sus observaciones sobre la agricultura. Lo variopinto de la selección pretendió demostrar la múltiple erudición intelectual y el compromiso con el entorno social y político que tanto Larrañaga como Pérez Castellanos tuvieron, así como también la poca especialización en las diversas ramas del conocimiento que existía durante los años de la colonia y de las primeras repúblicas independientes.

El tercer nombre que aparece en la cita es el de Bauzá, que dentro de la Colección... fue el más editado, con 11 volúmenes en su haber. Es bien sabida la importancia que le reconoció Pivel a este historiador. No solo se reeditó su obra paradigmática, la Historia de la dominación ..., sino que además ésta tuvo el prólogo más importante de toda la serie, con más de 650 páginas, el cual fue redactado por el propio Pivel. ${ }^{195}$ Bauzá fue sinónimo de estudio histórico documentado y proartiguista, como el más encumbrado padre historiográfico de Uruguay, que llegó a observar su singularidad desde lejanas épocas coloniales, postura que Pivel siguió defendiendo en su posterior obra como historiador.

Finalmente, el autor del prólogo citó a dos literatos ampliamente publicados como Zorrilla de San Martín y Acevedo Díaz, quienes en total recibieron el privilegio de la edición de 18 tomos (13 y 5 respectivamente) dentro de la Colección... En primera instancia, el sentimiento nacional considerado por Pivel como "disperso" encontró en la literatura una amalgama cohesionadora que, a través de los cantos y performances públicas de Zorrilla de San Marín, como poeta oficialista de la patria, ayudó a conformar. Por otra parte, Acevedo Díaz, con su tetralogía histórica basada en la generación de Uruguay, a través de sus guerras civiles, permitió, en una mezcla de ficción y crónica historiográfica, darle el tinte romántico que todo nacimiento literario de país deseaba.

\footnotetext{
${ }^{193} \mathrm{El}$ integrarlos en una serie de libros sobre la nacionalidad uruguaya, cuando vivían antes de la existencia de Uruguay y que hasta vieron el nacimiento del nuevo país, resulta paradójico. Serían nacionalistas antes de la conformación de la nación, aunque para Pivel la nación haya sido anterior a la creación de Uruguay.

${ }^{194}$ En 1816, junto a Manuel Barreiro, creó esa institución, durante las épocas revolucionarias.

${ }^{195}$ Texto que analizaremos más adelante.
} 
Según cuenta el propio Pivel en la cita precedente, los caracteres de la nacionalidad fueron edificados luego de un largo proceso, donde las distintas disciplinas (tanto artísticas como de conocimiento histórico) le fueron aportando los pilares en los que apoyarse. A nivel histórico, tanto Larrañaga como Pérez Castellanos fueron los primeros diseñadores que constituyeron un proyecto que llegó a ser aceptado cuando se logró la independencia. Ambos vivieron contemporáneamente todo el proceso revolucionario oriental que desembocaría en la constitución de Uruguay como Estado. Sin embargo, fueron Bauzá, como dueño de la justificación historiográfica, y Reyes, señalando las características formales y ya predeterminadas del nuevo país, quienes terminaron de presentar los documentos irrevocables de la construcción de la nueva nación en el concierto mundial. Zorrilla de San Martín encauzó las obras, organizando las fuerzas dispersas para concentrar el empeño en una única dirección, mientras que Acevedo Díaz, ensalzando a cada uno de los constructores, marcó los caracteres esenciales y heroicos que valieran su reconocimiento por encima del resto.

\section{La justificación historiográfica}

Como dijimos, el canon delineado desde la Colección ... tuvo intenciones hegemónicas. Si bien desde la literatura una gran cantidad de críticos las habían esbozado, y hasta habían hecho sus panorámicas, ensayando y proponiendo autores y obras canónicas ${ }^{196}$, no sucedió lo mismo con la historiografía. El camino, aún virgen de propuestas, fue ocupado y transitado por el Estado, y el encargado de su construcción fue Pivel. En el momento en que se comenzó a crear el canon historiográfico, Pivel se encontraba en pleno auge de su dominio académico. Con un nombre forjado y un campo hegemonizado por sus posturas historiográficas, el historiador nacional era quien mejor podía hacer cumplir la meta de mantener una actitud neutral con respecto al relato oficial.

Pivel eligió las obras y además se hizo cargo de sus prólogos, lo que terminó de completar un ejercicio simbólico eficaz. No solo se erigía como censor entre sus pares, sino que además establecía una determinada interpretación sobre sus libros. Esa conducción de lectura estuvo abocada a acotar, en algunos tópicos, los sentidos de las obras prologadas por su editor. En lugar de abrir las interpretaciones de las obras, Pivel se concentró en cerrarlas. ${ }^{197}$ La visión paternalista, conservadora y unívoca que tenía Pivel sobre el proceso histórico nacional fue plasmándose en dichos prólogos.

\footnotetext{
${ }^{196}$ Ver Capítulo 6.

${ }^{197}$ Para el concepto de "obra abierta” ver Eco (1992).
} 
Para desarrollar nuestras apreciaciones, consideraremos cuatro prólogos hechos por Pivel a libros de De la Sota, Magariños Cervantes, Berro y Bauzá, ${ }^{198}$ haciendo hincapié especialmente en el realizado a su padre historiográfico, Bauzá.

Pivel hizo patente su deseo de editar la Historia del territorio oriental del Uruguay de Juan Manuel de la Sota ${ }^{199}$ (1965c), que partía del propio derrotero historiográfico que lo marcó en sus primeros años como historiador. Además de los temas acerca de los cuales trataba la obra, con un marcado tinte de corte nacional y por ser una obra pionera en su materia, daba suficiente justificación como para llevar adelante el proyecto de su edición, y lógicamente de su prólogo.

Este libro en cuestión fue pensado originalmente para dar a los maestros una obra de instrucción básica sobre el proceso histórico nacional. Sin embargo, debido a las dificultades que tuvo De la Sota para llevar adelante su investigación, la Historia... terminó siendo una síntesis o glosa de memorialistas y cronistas de la época. ${ }^{200}$

El tema central del libro, según manifestaba el prologuista, era la disputa por el territorio de Uruguay. El relato hecho por De la Sota llegaba hasta 1776, aunque había otros trabajos que iban más allá de ese corte cronológico. Sin embargo, la edición quedó inconclusa, ya que se habían perdido los originales. Según señalaba Pivel, la publicación original debió interrumpirse en 1842 por falta de apoyos privados y públicos, ya que De la Sota estaba fuera de los círculos de poder (Pivel, 1965c, pp. 27-28). Esta referencia no es ingenua, ya que Pivel ensayaba cierta identificación del autor estudiado con su propio derrotero biográfico ${ }^{201}$.

Además, De la Sota desarrolló, en su ya señalado carácter de pionero, varios de los tópicos propuestos luego por Pivel como los centrales de la historiografía uruguaya. El historiador reseñado se adscribía, al igual que nuestro prologuista, a la tesis de que el inicio de la independencia del país debía fijarse a partir de 1825, desde la Cruzada Libertadora. Sumado al

\footnotetext{
${ }^{198}$ Cabe destacar que, además de los prólogos a las obras aquí consideradas, Pivel participó de otros, pero de menor trascendencia, elaborados fuera de su período de gestión como ministro. Primero, las Memorias de César Díaz; justificó su edición en base a la importancia que tuvo como militar y como redactor de sus recuerdos sobre diferentes sucesos de la vida en batalla. Fue colorado y estuvo en la batalla de Arroyo Grande (1842) y en la defensa de Montevideo (1843-1851). Además, participó activamente en la batalla de Caseros de 1852, donde, según sus memorias, tuvo un muy buen desempeño junto al ejército oriental —el primero en atacar y ocupar posición en Caseros-. Según Pivel, el mismo Bauzá llegó a elogiar el texto del general Díaz, que fue un militar que ciertamente tuvo virtudes con la pluma así como las había tenido con el sable (Pivel, 1968).

${ }^{199}$ Juan Manuel de la Sota (1800?-1858), nacido en Santa Fe, con actuación militar en el Regimiento de Voluntarios de la Caballería, se radicó en Uruguay hacia 1829, huyendo del enfrentamiento entre unitarios y federales. Una vez en Montevideo desempeñó tareas como preceptor en la Escuela Normal. Además, tuvo varias tareas en la administración pública como secretario, funcionario de la Jefatura de Policía, archivero público y senador por el departamento de Tacuarembó. Murió en Córdoba (Argentina) en 1858.

${ }^{200}$ Este libro, considerado como una de las primeras manifestaciones de la historiografía didascálica en el Río de la Plata, estaba organizado para facilitar la comprensión memorística del lector, llevando adelante una exposición cronológica de los acontecimientos (Sansón, 2011b).

${ }^{201}$ Veremos más claramente esta idea cuando estudiemos el prólogo que le hizo a Bauzá.
} 
interés por los problemas de límites con Brasil ${ }^{202}$ que tomara estatus público hacia 1832, invitó a De la Sota a preguntarse por la historia de Uruguay, donde vivía desde 1829 (Pivel 1965c). Por ello, Pivel señaló que

De la Sota trazó esta primera versión de los hechos que tuvieron por escenario el territorio de nuestro país, con un sentido político, con el propósito de extraer de esos hechos una filosofía que contribuyera a definir y a vigorizar la conciencia nacional (1965c, p. 10).

Pivel consideró que su nombre debía ser sacado del olvido gracias a su tarea como intelectual, y a su actividad como hombre político y de Estado. Se ganó la admiración de Pivel al desarrollar su tarea como investigador autodidacta, desde donde buscó que la historia sirviera a los intereses de la formación de los nuevos ciudadanos.

En consecuencia, en las conclusiones finales recogemos una autoconsagración piveliana a través del prólogo a De la Sota. Al final del estudio previo puede leerse una breve opinión sobre el autor de la obra, aunque podríamos decir lo mismo sobre el firmante del prólogo:

\begin{abstract}
Preceptor y autor didáctico en épocas heroicas, covachuelista metódico aplicado a la tarea de ordenar papeles, redactar actas, despachos y resoluciones que lucen su cuidada caligrafía, observador atento de nuestras cosas, sensible a los problemas del país, a la reforma y progreso de las instituciones; político a ratos, este modesto obrero de la cultura uruguaya fue un hombre que creyó en la influencia que el conocimiento de la historia podía ejercer en la educación de la juventud y en el destino de nuestra sociedad. El fervor con que se aplicó a estudiarla, a escribirla y a enseñarla justifican que su nombre y su obra sean rescatados del olvido (Pivel, 1965c, pp. 29-30).
\end{abstract}

Si bien la cuidada caligrafía no era una característica piveliana, la justificación esbozada por el prologuista para con De la Sota remarcaba cuáles eran los ideales de un hombre de Estado, los cuales Pivel se esforzó por alcanzar durante toda su carrera.

\footnotetext{
${ }^{202}$ Además, Pivel se veía identificado a raíz de varios intereses en común, ya que él mismo, como historiador, había estudiado los límites del Uruguay, y De la Sota fue una de sus primeras lecturas historiográficas sobre el tema. Ver el Capítulo 3.
} 


\section{La génesis historiográfica}

Existe un caso particular en el canon literario nacional que, si bien fue tenido en cuenta por la crítica literaria como una figura fundadora de las letras uruguayas, ${ }^{203}$ ingresó en la Colección... gracias a una obra historiográfica. Nos referimos a Alejandro Magariños Cervantes. ${ }^{204}$

En el caso del prólogo a Estudios históricos, políticos y sociales sobre el Río de la Plata (1963), nos parece trascendente detenernos en el autor de la obra, ya que se encontraba en medio de los dos discursos, el historiográfico y el literario. Pivel, conocedor de la dualidad de Magariños Cervantes, pretendió llevar a cabo un estudio enfocado en el nacionalismo histórico y literario del autor.

En función de ello, el prologuista anotó que

Magariños Cervantes se sintió profundamente tocado por estas ideas que abogaban por un nacionalismo literario, sin mengua de la universalidad del arte, por una literatura que fuera el reflejo de nuestra realidad y del estado social de nuestro pueblo, animada por un dogma religiosa, por el ideal de la fe [...] tuvo una aspiración: ser un poeta, un escritor de contenido y proyección americanas, propósito que animó a la mayoría de los escritores de la generación romántica (Pivel, 1963, p. 9).

El nombre de Magariños Cervantes ya aparecía en numerosos estudios críticos de literatura nacional, ${ }^{205}$ sobre todo por su actividad como novelista romántico; sin embargo, la Comisión de la Colección... optó por editar sus estudios históricos.

Si bien los prologados por Pivel eran autodidactas, Magariños Cervantes era la excepción. Gracias a integrar un grupo social acomodado - ya que pertenecía a una familia patricia $^{206}$ — estaba formado académicamente por importantes preceptores del medio.

Según Pivel, a los veinte años de edad, Magariños Cervantes se dejó arrastrar por el romanticismo imperante en la época, y buscó ser el cantor del drama histórico representado en

\footnotetext{
${ }^{203}$ Ver el Capítulo 6.

${ }^{204}$ Alejandro Magariños Cervantes (1825-1880), nacido en Montevideo, desde muy temprana edad, y luego de pasar por varios preceptores durante sus años escolares, ingresó en la Academia de Jurisprudencia, para realizar estudios que no logró terminar, por viajar y residir en Río de Janeiro, pero que luego culminaría en España hacia 1855. Posteriormente se trasladó a Madrid, en donde escribió novelas y se relacionó con los escritores más importantes de su época. Luego de varios viajes por Europa, regresó a Montevideo, y adhirió a la política de fusión, y trabajó con el futuro presidente Gabriel Pereira. Fue cónsul en Buenos Aires y se dedicó a tareas editoriales, publicando la Biblioteca Americana, una selección de autores rioplatenses. Volvió a Montevideo, y en 1862 ocupó una cátedra en Derecho, para luego ser nombrado en 1878 rector de la Universidad. Además de literatura, Magariños Cervantes publicó obras historiográficas y dedicadas al derecho. Murió en Montevideo en 1880. Ver Pivel (1963).

${ }^{205}$ Sobre su actividad como novelista y la relación con el canon literario, ver Capítulo 6.

${ }^{206}$ El origen social de Magariños Cervantes era por lo menos dudoso a los ojos nacionalistas. En 1820, la familia había sido enemiga de la causa americana. Sin embargo, Pivel recordó que el padre de Magariños Cervantes había combatido en las batallas de Ituzaingó y Sarandí, lo que lo hacía contribuyente a la independencia de Uruguay (Pivel, 1963, p. 12).
} 
el territorio uruguayo durante la Guerra Grande. Esa búsqueda para ser un literato lo alejó del periodismo partidista que se practicaba tanto en el gobierno del Cerrito como en el de la Defensa. ${ }^{207}$ Según el prologuista, Magariños Cervantes prefería la reconciliación nacional, y a ello dedicó su obra y su tiempo (Pivel, 1963, p. 12). Esa superación de los conflictos entre los dos partidos políticos era por lo que luchaba el propio Pivel desde su obra historiográfica y, además, era el dominante en términos constitucionales en Uruguay. ${ }^{208}$

El prologado repartió su derrotero biográfico entre España y Uruguay. Pivel sostuvo que, pese a vivir, estudiar y editar en España, Magariños Cervantes tuvo incidencia en el continente americano debido a la gran cantidad de proyectos editoriales que pretendieron favorecer el desarrollo intelectual de la región y del que haremos referencia más adelante. Además, desde el prólogo de la Colección... se consideraba necesario resaltar

\begin{abstract}
... la concepción americanista de sus temas, la honradez con que trabajó para dar a nuestras letras un acento nacional y el no pequeño [objetivo] que resulta haber divulgado en un escenario europeo, tan ausente de la realidad americana como era el de la España de la época, los rasgos más salientes de la vida de estos pueblos (Pivel, 1963, p. 17).
\end{abstract}

Estas virtudes eran consideradas suficientes como para justificar su edición en el canon literario nacional.

Por otro lado, y de manera similar a Pivel con todos los proyectos que ya hemos mencionado, Magariños Cervantes fue el principal artífice en la fundación de la Revista Española de Ambos Mundos, y de la Biblioteca Americana, que

\begin{abstract}
... estaba destinada a difundir las obras de los escritores del Nuevo Mundo, a los que solicitó su concurso para realizar la obra que emprendía con sujeción a estas ideas: liberal en literatura como en política, deseoso de consagrarme mientras permanezca en Europa, a empresas de interés supremo para el hemisferio en que nací; anhelando fomentar, difundir y popularizar las obras del ingenio americano, y de reunir materiales para crear una literatura nacional, daré cabida, sin restricción, bajo las bases que indicaré, a todas las obras — cualesquiera que sea su género- que se confíen y juzgue dignas de ver la luz pública» Generoso proyecto como todos los suyos, para el cual no encontró apoyo, pues apenas llegó a concretarse con la publicación de la primera entrega el tomo único que reunía sus «Estudios Históricos, Políticos y Sociales sobre el Río de la Plata», que apareció en Paris en 1854 (Pivel, 1963, pp. 25-26).
\end{abstract}

\footnotetext{
${ }^{207}$ Sobre dicha terminología con respecto a la Guerra Grande, ver Pivel (1945).

${ }^{208}$ Recordemos que, gracias a la constitución de 1952, el Poder Ejecutivo estaba integrado por un órgano colegiado del que participaban los dos partidos mayoritarios.
} 
Nuevamente, los apuntes hechos sobre la vida del autor a la que se le dedicó el estudio previo cumplían con la autorreferencia constante en la que Pivel incurría en sus prólogos. En este caso, citó el proyecto de publicación de libros que permitían “difundir y popularizar" obras americanas. ${ }^{209}$ La idea de este tipo de biblioteca, que conjugaba muchos de los objetivos e intereses planteados por Magariños Cervantes durante el siglo XIX, no apareció hasta la existencia a nivel nacional de la Colección..., y a nivel americano de la Biblioteca Ayacucho. ${ }^{210}$

Según explicaba Pivel, autolegitimándose, todo el trabajo del literato-historiador antes mencionado estuvo basado en el «anhelo de formar la conciencia nacional mediante la exaltación de sus valores propios» (Pivel, 1963, p. 48), y su actuación pública no lo separó de sus sentimientos para llevar adelante sus ideas.

Al final del prólogo, Pivel señaló que

\begin{abstract}
Magariños Cervantes reveló aptitudes positivas para el estudio de la historia, disciplina a la cual en nuestro medio pocas voluntades se habían consagrado en la primera mitad del siglo pasado. Antes de 1854 la bibliografía histórica del país se reduce, en lo esencial, a la «Historia del Territorio Oriental del Uruguay» publicada en 1841 por Juan Manuel de la Sota, a las contribuciones recogidas en la «Biblioteca del Comercio del Plata», editada entre 1845 y 1851, y en la «Colección de Documentos» impresa por Andrés Lamas en 1849, y a los primeros trabajos de Isidoro de María. Su preocupación por acudir a las fuentes más serias, la serenidad de sus juicios sobre los temas que ya podían ser apreciados con perspectiva histórica, la sobriedad de su estilo, realizan los méritos de la labor de Magariños Cervantes, en la que es de lamentar no persistiera después de su regreso al Río de la Plata, cuyo pasado solamente entrevió como un gran tema de estudio cuando, a la distancia, se sintió dominado por la nostalgia de la patria lejana (Pivel, 1963, p. 54).
\end{abstract}

Los antecedentes al texto reseñado por Pivel cumplían en señalar qué obras llevaban a buen puerto el construir inicialmente una Historia de Uruguay. Claramente, en todos los casos, los distintos autores y obras mencionadas fueron publicados por la Colección... y prologados por Pivel, lo que supone reafirmar su condición de continuador historiográfico oficial del país.

Sin dudas, ese programa y estilo de escritura -que según Pivel poseía el autor- eran los que él mismo pretendía sostener en su producción historiográfica, y los que creía necesitar para escribir la Historia del Uruguay, su Historia nacional.

\footnotetext{
${ }^{209}$ Este tipo de colección fue una constante necesidad cultural que el autor prologado pretendió hacer efectiva durante su estancia en la región. En 1858, Magariños Cervantes insistió en volver a editar dentro la serie de libros americanistas, en la que logró sumar un total de diez entregas, primero en Buenos Aires y para los últimos dos tomos en Montevideo hacia 1864.

${ }^{210}$ Ángel Rama, quien fuera su creador y director a partir de 1974 en Venezuela, también fue prologuista de la Colección...
} 


\section{Berro y el ejemplo de político nacional}

En el imaginario del Partido Nacional, la figura de Bernardo Prudencio Berro ${ }^{211}$ fue de las más sobresalientes del siglo XIX; fue el último de los presidentes blancos antes de la victoria en las elecciones de 1958 y, además, representaba los intereses de los doctores frente al de los caudillos, siendo una figura paradigmática de la política de fusión ${ }^{212}$ durante su presidencia en Uruguay.

La Colección... publicó dos libros basados en los escritos políticos de Berro. Respecto del enfrentamiento discursivo que tuvo con Manuel Herrera y Obes, se editaron El caudillismo y la revolución americana. Polémica (vol. 110, 1966), y en el volumen siguiente se imprimieron sus Escritos selectos (vol. 111, 1966). Ambas publicaciones salieron a la luz con importantes estudios previos — de 36 y 45 páginas respectivamente — del ministro-editor Pivel.

En el primer caso, Pivel pretendió trabajar el caudillismo, tema recurrente en su obra historiográfica. Al comienzo del prólogo, y luego de presentar las posturas dicotómicas, primó el sentimiento conciliador piveliano, ya que la idea del prologuista era realizar una caracterización de los caudillos, remontándose a los orígenes del fenómeno durante la aparición de los primeros conquistadores en el continente.

Una de las cualidades más sobresalientes era que el poder del caudillo se basaba en que eran elegidos por el pueblo y que obtenían el poder por herencia. Pivel pretendió defender el Uruguay caudillesco, y a muchas de las figuras del siglo XIX como Artigas, Rivera, Oribe y Lavalleja, entre otros. Por ello, terminó sintentizando que el caudillismo fue en nuestro continente una «expresión primitiva y elemental de la voluntad popular» (Pivel, 1966, p. 16). Es más, Pivel señalaba que la palabra caudillo había tenido un cambio semántico, pues pasó de ser positiva a connotar algo negativo — volviéndose sinónimo de 'gente revoltosa' —, y fue Artigas, desde 1827 uno de los primeros en caer bajo ese epíteto (Pivel, 1966). ${ }^{213}$

\footnotetext{
${ }^{211}$ Bernardo Prudencio Berro (1803-1868), nacido en Montevideo, fue un político y diplomático uruguayo de medular importancia para los primeros años de vida del país. Fue militante de Oribe, contrario a Rivera, y uno de los principales dinamizadores del Partido Blanco. Adhirió a la política de fusión entre los partidos políticos luego de la Guerra Grande. Además de varios puestos en la administración nacional, consiguió en 1860 ser elegido presidente, cargo que ocupó hasta 1864. Posteriormente, en 1868 acaudilló una revolución contra el gobierno de Venancio Flores y Pedro Varela, hecho que le costó la vida, ya que fue asesinado y su cuerpo fue paseado por la ciudad de Montevideo.

${ }^{212}$ Luego de la Guerra Grande se establecieron dos salidas políticas para terminar con los enfrentamientos entre blancos y colorados. Las políticas de pactos - manteniendo la separación de los partidos, apoyados por los caudillos - y las de fusión - terminar con la división y fusionarse, creando algo nuevo y separador del antiguo enfrentamiento, apoyado por los doctores - . Ver Pivel (1945), Nahum (2011), Caetano y Rilla (1999).

${ }^{213}$ Como señalaba Pivel, los sectores dirigentes, al cambiar el orden de las cosas durante el período artiguista, y con la promoción de la «anarquía» y del «tumulto popular», hicieron lo posible por desacreditar a los caudillos. Desde 1822 en adelante, dichos sectores se apuraron a enjuiciar la época de Artigas por temor a la vuelta al caudillismo. Santiago Vázquez fue quien se encargó en 1826 de hablar negativamente de Rivera, quien era el caudillo más resonante del período, y el futuro presidente del Uruguay. Los constituyentes de 1830 se manifestaron contra Rivera y Lavalleja, pero cuando don Frutos ganó la presidencia, su vínculo con los sectores dirigentes
} 
Por ejemplo, con respecto a Oribe, en su prólogo Pivel consideró que había sido un adelantado a su época al querer organizar el nuevo Estado. Luego de la derrota de Rivera en India Muerta, hacia 1845, y a su posterior autoexilio en Brasil, la clase doctoral de Montevideo defendió el choque dicotómico entre civilización y barbarie. A raíz de ello, Pivel terminó afirmando que

\begin{abstract}
El alejamiento de Rivera derrotado en India Muerta pocos meses antes, dejó libre el campo a los que anhelaban orientar los actos del gobierno de la Defensa con sujeción a estas ideas contrarias al caudillismo, cuyo enjuiciamiento era hecho por los publicistas con el auxilio de escasos conocimientos históricos y convencionales interpretaciones sociológicas al servicio de un fin político (Pivel, 1966, pp. 28-29).
\end{abstract}

El enfrentamiento de Pivel con los intelectuales de la época que reseñada, lo llevó a decir que se oponía al Instituto Histórico que Lamas y Echeverría habían creado, ${ }^{214}$ debido a que tenía él mismo una opinión contraria a los caudillos (Pivel, 1966, p. 26). En este caso, la tarea historiográfica a la que se estaba abocando nuestro prologuista era la de conciliar los dos segmentos de su partido político y, por lo tanto, los del Uruguay del siglo XIX: caudillos y doctores.

Entrando en la obra, Pivel presentó las diferentes posturas de los dos protagonistas de la polémica. Por un lado Herrera y Obes, contrario al caudillismo, manifestaba que «Rivera, Lavalleja, Oribe, Rosas, eran expresión de la época y de la sociedad en que actuaban. Desaparecerían al transformarse esa sociedad. El caudillismo que encarnaban tenía sus raíces en el pasado» (Pivel, 1966, p. 32). La explicación que daba Herrera y Obes con respecto a la lucha de intereses se justificaba de esta manera:

\begin{abstract}
El movimiento emancipador dividió a América en diferentes estados, pero la sociedad americana era una sola, estaba formada por un solo pueblo, en el que se distingue dos elementos: el reaccionario que proviene del desierto y prolonga las costumbres tradicionales, y el renovador que tiene su asiento en las ciudades. La reacción sostenida por las masas incultas y la revolución impulsada por la clase ilustrada, con el nombre de los partidos políticos se trabaron en lucha. Los caudillos personificaron los sentimientos de las masas incultas organizadas para la guerra, en tanto que la clase civilizada, que es la suma de todas las inteligencias, no podía ser representada por un hombre. Esas dos tendencias estaban separadas por las murallas de Montevideo (Pivel, 1966, p. 23).
\end{abstract}

mejoró notoriamente, ya que al final optaron por apoyarlo en 1836 debido a su enfrentamiento con Rosas —o como le llamaban los sectores de la oligarquía oriental, «El Artigas porteño» (Pivel, 1966, p. 22)—.

${ }^{214}$ También sucederá lo mismo con Sarmiento y Mitre. 
Esta opinión manifestaba otra vez las dicotomías: civilización/barbarie, campo/ciudad y caudillos/doctores.

Posteriormente en el mismo prólogo, Pivel presentó a Berro quien, según manifestó, refutó las posturas de Herrera y Obes. En este punto, se presentaron dos figuras de distintos partidos políticos y representantes de dos medios diferentes. Pivel le otorgó la victoria discursiva a Berro, que además era de su propio bando político, no casualmente.

Para concluir, Pivel prefirió nuevamente expresar una postura conciliadora, ya que finalizó el estudio previo diciendo que:

\begin{abstract}
Hoy podemos afirmar que no existió un país civilizado y un país bárbaro, ni un sector de la sociedad con el monopolio de la libertad y de los derechos del hombre, frente a otro al que se hace aparecer sometido hasta la abyección a la voluntad del poder absoluto. La verdad es que las tendencias antagónicas tuvieron un origen común y se manifestaron en el seno de una misma sociedad. En el período revolucionario esas tendencias estuvieron representadas por la clase ilustrada, la oligarquía radicada por lo común en las ciudades, formada por un patriciado altivo y reacio a aceptar los cambios sociales y políticos impuestos por la revolución, núcleo proclive a la monarquía y a las tortuosas soluciones diplomáticas, a las que apeló para conservar el poder que el caudillismo le disputaba y que no le había sido conferido por la voluntad colectiva; y en contraposición a esta clase, el pueblo inculto y tumultuario, orientado por el caudillo, expresión instintiva de una fuerza vital, la gauchocracia si se quiere, pero identificada con la tarea y el ideal de la libertad republicana y representativa en la que debía cimentarse la organización de los nuevos Estados (Pivel, 1966, p. 42).
\end{abstract}

Además de la polémica planteada, se publicó en segunda instancia una selección de escritos de Berro. Pivel inició este nuevo estudio previo marcando algunas de sus características y resaltando que Berro fue, como hombre político, una persona racional contraria a la revolución y a favor de la educación como avance del individuo dentro de la sociedad.

Según citaba Pivel, Berro pensaba que «Ningún partido — dividida que fuese la nación en dos bandos - tiene derecho para someter al otro a su dominio, desde que ambos participan de igual manera en la soberanía» (Pivel, 1966b, p. 19). Claramente esa idea, cara a la política de fusión, era de alguna manera continuadora y justificadora del período histórico y político que le tocaba vivir al ministro-prologuista Pivel. Como citáramos anteriormente, la Constitución de 1952, con la integración de los dos partidos más votados al colegiado — por aquellos años: blancos y colorados_-, era de alguna manera una culminación contemporánea de las ideas que defendió Berro en el siglo XIX. La idea perseguida inicialmente por el autor era 
permanecer neutral en los enfrentamientos entre partidos políticos, para amalgamarlos y así unir la nación..$^{215}$

Sin embargo, Pivel consideraba que Berro había cometido un error, ya que cuando fue presidente en 1860 se pronunció en contra del resurgimiento de los partidos, prohibiendo las banderas y

\begin{abstract}
A pesar de ello, los partidos resurgieron porque eran una exigencia del sistema republicano - aun cuando Berro, partiendo de un principio abstracto, no los creyera indispensables para estabilizar la República- y porque los factores sociales y los sentimientos personales que le dieron nacimiento se habían convertido, a través de los años, en fuerzas de hondo y apasionante contenido histórico (Pivel, 1966b, p. 35).
\end{abstract}

Claro que si bien el autor prologado servía a los intereses historiográficos de Pivel, relacionados mayoritariamente con enaltecer la figura de los caudillos lo cual que era coherente con sus bases historiográficas, tenía que señalar algunas discrepancias importantes. La idea de corrección que asumía el prologuista encarnaba ese sentido paternalista consuetudinario que manejó durante todos sus prólogos.

Pivel afirmó que Berro no fue un político como los que se conocían durante el siglo XX, sino que «fue el ideólogo de la República y del sistema representativo en un ambiente en el que existían escasos elementos para fundar la República y para ensayar el sufragio» (Pivel, 1966b, p. 51). Berro resaltaba la necesidad de mantener nuestra independencia frente a los dos gigantes vecinos que presionaban sobre la supuesta inviabilidad que Uruguay mostraba a la salida de la Guerra Grande (Pivel, 1966b, pp. 46-47). Por ello, apoyaba la necesidad de firmar un tratado de neutralidad con las potencias europeas y las vecinas. Su ideal de independencia y nacionalidad, sostenido en su actuación política, junto con su neutralidad partidaria, en quizás uno de los momentos más difíciles de la historia del Uruguay ${ }^{216}$, fue el que le mereció un lugar en el canon configurado desde la Colección... dirigida por Pivel.

\title{
La justificación historiográfica: el ejemplo de Bauzá
}

En 1965 se editó, en la Colección..., una de las obras que, según su editor, fue de las fundamentales en su vida para el acercamiento a la disciplina histórica: la Historia de la dominación

\footnotetext{
${ }^{215} \mathrm{Al}$ estar de acuerdo con los ideales blancos de defensa de las instituciones, como según su origen propició, la bandera blanca seguía despertando rechazos, por lo que quiso crear un nuevo partido, el Blanco-Constitucional fusionista (Pivel, 1966b, p. 30)-.

${ }^{216} \mathrm{La}$ Guerra Grande puso en duda la viabilidad del país. Las políticas de pacto y fusión posteriores quisieron mantener la paz entre las banderías políticas para salir de la crisis económica que asolaba al Uruguay.
} 
española en el Uruguay de Francisco Bauzá, un político y militante del Partido Colorado que, además de senador, diputado, ministro y representante diplomático en Argentina y Brasil, llegó a ser candidato a la presidencia en 1893. También fue periodista (en El Nacional como redactor, ${ }^{217}$ y en Los Debates como fundador), y autor de varias obras sobre historia, derecho, economía y pedagogía. Publicó Ensayo sobre la formación de la clase media (1876), Estudios literarios (1885) y Estudios Constitucionales (1887), pero su libro más importante fue la Historia de la dominación española en el Uruguay (que tuvo una primera edición entre 1880-1882, y otra corregida y aumentada entre 1895-1897). Fue ferviente católico (se puede observar esto en numerosos pasajes de su obra), hecho que lo desplazó de la cátedra de historia nacional en la Universidad, frente a Clemente Fregeiro ${ }^{218}$ (Ribeiro, 1994, p. 43).

Bauzá fue un autodidacta, como todos los autores de la época; buscaba emular modelos americanos y europeos que le sirvieran de guía para sus propios estudios históricos. ${ }^{219} \mathrm{El}$ campo historiográfico estaba en formación y se hacía imposible dedicarse enteramente a la disciplina histórica.

Durante su carrera «se apoyó en la Historia para defender principios, luchar por la consolidación de la nacionalidad uruguaya, y definir la identidad colectiva del país». Además, como lo demuestra su actividad pública e intelectual, «consideraba que la Historia era una disciplina fundamental para formar a las nuevas generaciones en el sentimiento de amor a la patria, apego a las tradiciones y reconocimiento de los grandes hombres que contribuyeron a fundar la nacionalidad» (Sansón, 2007, p. 43). No nos parece extraño que Pivel se sintiera identificado con Bauzá, que pensaran ambos que la disciplina histórica era la que mejor justificaba el ser nacional, y que aprovechando su puesto de editor, se esforzase por hacer llegar su obra casi íntegra a la ciudadanía uruguaya. Además, para llevar adelante la tarea, bien podría valerse de los supuestos valores superiores que el autor tenía; recordemos que Pivel afirmaba que «de todos los historiadores americanos del siglo XIX, Francisco Bauzá es quizás el que reúna mayor cantidad de condiciones positivas» (Pivel, 1965, pp. 220-221).

\footnotetext{
${ }^{217}$ Según Pivel, fue allí donde Bauzá hizo sus primeras armas como periodista, y donde comenzó con su prédica nacionalista. Algunos de los tópicos tratados fueron de interés para Pivel durante toda su carrera historiográfica e intelectual, a saber: «El desenlace decoroso para el país de la guerra contra el Paraguay, el restablecimiento del orden institucional y las libertades públicas, el destino de las Repúblicas Americanas, y el progreso de la educación...» (Pivel, 1965, p. 18).

${ }^{218}$ Historiador que impuso el término éxodo para designar la marcha de las tropas revolucionarias orientales comandadas por José Artigas en 1811 desde Montevideo (en estado de sitio por parte de Artigas y José Rondeau) hasta el Ayuí, luego de la invasión portuguesa de ese año.

${ }^{219}$ Para más información, ver Sansón (2007).
} 
De hecho, Bauzá es el historiador más editado por la Colección, con diez volúmenes que demuestran lo variada que fue su obra. ${ }^{220}$ Como recordáramos, este intelectual generó un sentimiento particular en Pivel ya que, según comentó, fue quien lo acercó al estudio de la historia, especialmente el libro que nos ocupa (el cual, además, tuvo trascendencia simbólica en su vida, ya que fue el último regalo de su madre antes de morir; Vidaurreta, 2001, p. 24).

Dentro de la biblioteca personal de Pivel, se encontraron las dos ediciones de la Historia... previas a la editada por parte de la Colección... La primera de ellas (desde 1880 hasta 1882) en tres tomos impresos por la Tipográfica de Marella Hnos., y la otra por Barreiro y Ramos entre 1895 y 1897 (que fue la primera que tuvo Pivel, según consta en la entrevista hecha por Vidaurreta, 2001). De alguna manera, la edición llevada adelante por la Colección ... permitió popularizar la obra, haciéndola más accesible, ya que era muy cara y difícil de hallar.

Según Pivel, podemos concluir que la Historia... resulta un libro fundamental para justificar los primeros rasgos del nacionalismo impulsado posteriormente por otros autores.

El libro fue escrito básicamente en un impasse de la vida política de Bauzá, como consecuencia de la dictadura de Lorenzo Latorre (1844-1916). ${ }^{221}$ Bauzá buscó allí los orígenes de la nacionalidad en todos los ámbitos posibles, desde lo histórico, lo económico, lo geográfico, lo político y lo social. Se propone abordar lo sucedido desde el descubrimiento, pasando por el período colonial y la «revolución uruguaya», llegando hasta el fin del ciclo artiguista en 1820. La Colonia es vista como el inicio de todo lo que posteriormente se constituyó. Pivel señala que Bauzá «creyó con acierto que la existencia del Uruguay soberano e independiente no podía ser explicada sin el estudio pormenorizado del período colonial durante el cual se gestó el embrión social del que nació la comunidad uruguaya; que debía remitirse a los orígenes, al génesis de nuestro proceso histórico, al estudio de las raíces para poder discurrir con propiedad sobre los fundamentos de la nacionalidad» (Pivel, 1965, pp. 209210). Se basó en que la misión de España en la región fue de carácter "civilizatorio", imponiendo las costumbres, el idioma y la religión católica. Por otra parte, la figura de Artigas fue resaltada como la de un caudillo federal y republicano, que además se encargó de conducir la «revolución uruguaya». Bauzá menciona a los indígenas, y particularmente a los charrúas, que se habrían movido dentro de los límites precisos de la nueva nación, e incluso llegó a remitir a la República Charrúa para referirse a Uruguay.

\footnotetext{
${ }^{220}$ Se editaron Estudios Literarios (1953, vol. 9), Estudios Constitucionales (1953, vol. 11), Historia de la Dominación Española en Uruguay (1965, vols. 95-100), Estudios Sociales y Económicos (1972, vols. 140-141), y junto a otros autores La Independencia Nacional (1975, vol. 145).

${ }^{22} \mathrm{Se}$ trata de un militar y político que llegó al poder de facto como gobernador provisorio entre 1876 y 1879 , y posteriormente fue presidente constitucional entre 1879 y 1880, cuando renunció. El fuerte apoyo de los sectores del capital extranjero (sobre todo británico), los hacendados, el alto comercio y los militares permitieron que emprendiera una modernización del país, que buscaba ingresar al mercado capitalista mundial de materias primas.
} 
La metodología que aplicó se basó en tres planos: la exposición de los hechos (en donde demostró su erudición documental y su crítica a los acontecimientos, llevando adelante apreciaciones y juicios valorativos sobre ellos), los apéndices críticos (en donde ensayó una interpretación sociológica), y los documentos de prueba (Ribeiro 1994, p. 43), en donde «valoró la importancia que tenía para el desarrollo de los estudios históricos la publicación de las fuentes documentales inéditas» (Pivel, 1965b, p 154).

El prólogo a la Historia... de Bauzá es el más extenso de toda la Colección..., lo que muestra la importancia que le otorgó y lo que sentía por esa obra, ya que hablamos de 679 páginas divididas en dos partes del primer tomo, de los seis que tiene de extensión la edición referida. ${ }^{222}$ Con la magnitud de esta investigación inicial, estamos frente a una obra dentro de otra, en un caso único dentro de la Colección... ${ }^{223}$

Por otro lado, es importante destacar que si observamos las 344 citas a pie de página que contiene todo el prólogo, la gran mayoría de las fuentes secundarias son de los prólogos de la Colección..., artículos de la Revista Histórica, y publicaciones periodísticas de Pivel en Marcha. Por lo tanto, podemos afirmar que este estudio es autorreferencial hasta en su justificación bibliográfica. No solo Pivel se cita a sí mismo, sino también a aquellos en los que confió para sus proyectos editoriales. 224

Asumiendo la hipótesis planteada, observamos que Pivel hizo hincapié en la redacción de la obra, resaltando la supuesta «juventud» de Bauzá en su investigación y su publicación, al afirmar que

Bauzá escribió la Historia [...] cuando aún no había cumplido treinta años de edad, con el auxilio de fuentes bibliográficas y de los documentos que pudo consultar. La versión definitiva sería alcanzada después de cumplir una segunda etapa de revisión y ampliación de la obra con los nuevos materiales que acopió en el transcurso de una década [...] el libro de Bauzá fue recibido con una indiferente frialdad. Su autor no era hombre de círculo ni cultivaba las apariencias literarias. Hallábase apartado de la Universidad (Pivel, 1965, p. 222).

Hay que señalar que, en octubre de 1882, cuando se editó el último tomo del trabajo citado, Bauzá aún tenía 32 años. Este dato puede parecer curioso, pero debemos reinterpretarlo a lo luz del periplo personal del prologuista. Pivel subraya como un valor netamente positivo y que le agregaba un merecido halo consagratorio, la juventud con la que Bauzá había editado semejante

\footnotetext{
${ }^{222}$ Toda la obra acaparó desde el tomo 95 (dos partes) hasta el 100 y fue editada en 1965.

${ }^{223}$ Tres años más tarde, se publicará en forma autónoma un libro cuya temática será Bauzá y la historia nacional. Ver Pivel (1968).

${ }^{224}$ Además de citarse a él mismo, también remite a María Julia Ardao y Aurora C. de Castellanos.
} 
obra clave para la historiografía nacional. Ya que el mismo Pivel había editado, con 32 años, una de sus obras claves (y que consideró su mejor libro [Vidaurreta, 2001]): la Historia de los partidos políticos en el Uruguay (1942), también escrita en arduas horas de trabajo. Además, la posterior descripción del historiador también coincide con quién era Pivel para el círculo intelectual de la época: un autor aún sin renombre, apartado de la Universidad y que llevaba adelante una obra que hasta entonces al menos había sido poco recepcionada por el público uruguayo.

El estudio previo que hiciera Pivel pretende desarrollar una investigación pormenorizada sobre el autor y su obra, desplegando una historia intelectual con Bauzá, y es junto a él como se construye a sí mismo como tal. Su estudio intercaló las largas citas (ya que Pivel se caracterizó por extensas transcripciones de fuentes primarias y secundarias que podrían llegar a más de cinco páginas) con las consideraciones críticas. Además, no dejó de lado el contexto histórico por el que se movía Bauzá, que por ser hombre de la política no fue ajeno a ella, sino más bien fue partícipe y protagonista.

Si nos atenemos a la vida del propio Pivel, podríamos sustituir el nombre de Bauzá por el de él en cada uno de los capítulos. Recordemos que su figura implica varios papeles superpuestos, tal como sucede con Bauzá: el historiador nacional, el intelectual al servicio del Estado uruguayo, el funcionario público (editor, ministro, entre otros), y el militante político, en este caso en defensa del Partido Nacional.

Por lo tanto, Pivel pudo multiplicar a Bauzá en muchos otros, con diferentes tareas y responsabilidades. Es aquí donde una vez más los confundimos. ¿Es Bauzá todos esos hombres? ¿Es Pivel quien ve a Bauzá como él mismo se veía? Es muy probable que Pivel haya entendido, a partir del ejemplo magisterial de Bauzá como su precursor, que para construir un discurso nacional era necesario actuar en los diversos ámbitos de la vida pública, y transformarse en una figura dominante.

En el maratónico prólogo de la Historia ..., Pivel despliega así una suerte de identificación entre el prologuista y el prologado, viendo en Bauzá lo que quiere que vean en él. El discurso consagratorio de su padre simbólico (Bauzá) es una forma de legitimación de sí mismo.

\section{La nación encarnada}

A través de este prólogo, Pivel se dedicó a hacer historia, ya que justamente la vida de Bauzá se vio atravesada por los primeros años de vida independiente del Uruguay. La lucha por la conformación de la nueva nación, y la hegemonía discursiva esgrimida por el autor a finales del siglo XIX es, mutatis mutandis, la de Pivel a mitad del siglo XX. 
Frente a uno de los temas medulares expuestos por el prologuista, el de la nación, creemos que existen dos motores que impulsan las más de seiscientas páginas. Por un lado, la justificación de la nacionalidad uruguaya en sus orígenes coloniales y, por otro, el antagonismo discursivo llevado adelante frente a las posturas antinacionales y antiartiguistas.

Al comenzar a estudiar la vida de Bauzá emparentada con el naciente nacionalismo, Pivel decidió arrancar desde sus antepasados, relacionando ambas genealogías: la familia Bauzá y las luchas artiguistas por la independencia, que tuvieron su inicio en 1811. De esa manera, el prologuista pretendía llegar a la raíz nacional del autor. En la parte biográfica, Pivel se centró en el abordaje del contexto histórico junto con el origen de la familia de Bauzá, buscando aprehender el profundo sentido nacional del prologado. Su núcleo familiar marchó junto a Artigas durante el «Éxodo del Pueblo Oriental». Esa era la mejor manera de conectar a Bauzá con la figura que guardaba mejor los rasgos del ser uruguayo, como el mismísimo José Artigas.

El padre de Bauzá, Rufino (1791-1854), no solo luchó junto a las tropas revolucionarias durante los dos sitios a Montevideo (en 1811 y 1814), sino que también estuvo en la victoria de Guayabos el 10 de enero de 1815 cuando, junto a Fructuoso Rivera ${ }^{225}$ (1784-1854) y Juan Antonio Lavalleja ${ }^{226}$ (1784-1853), derrotaron a las fuerzas de Manuel Dorrego (1787-1828). Para Pivel, este acontecimiento significó un «hecho de armas [que] consolidó la independencia del territorio del Uruguay bajo la jefatura de Artigas, quien en el campo de batalla ascendió a Bauzá al grado de teniente coronel» (Pivel, 1965, p. 9).

Por lo tanto, desde el supuesto nacimiento de la nación política, hermanada con su caudillo Artigas, los Bauzá estaban predestinados a ser continuadores de la idea del Uruguay independiente: primero Rufino, luego su hijo natural Francisco, y finalmente -por qué no- el hijo intelectual del prologado, Pivel.

Una vez independizado, el Uruguay sintió sus conflictos civiles y regionales como pruebas de su existencia como nación separada de sus vecinas. Un ejemplo puede encontrarse en el gobierno de Lorenzo Batlle (1868-1972), cuando se gestó una revolución acaudillada por Timoteo Aparicio (1814-1882) y Anacleto Medina (1788-1871), conocida historiográficamente

\footnotetext{
${ }^{225}$ Fue uno de los generales artiguistas. Posteriormente se pasó al bando portugués en 1820 durante la invasión. Luego del Grito de Ipiranga (1822), y con la secesión de las fuerzas ocupantes, terminó del lado brasileño. Cuando se inició la Cruzada Libertadora en 1825, y tras un breve enfrentamiento, adhirió a los cruzados en un acontecimiento conocido historiográficamente como "el Abrazo del Monzón" (entre él y Lavalleja). Fue el primer presidente del Uruguay (1830-1834) y fundador del Partido Colorado.

${ }^{226}$ Fue uno de los generales artiguistas. Durante la invasión portuguesa (1816-1820) fue capturado en 1818 y llevado como prisionero a Río de Janeiro. Una vez devuelto a Montevideo (1821), se mantuvo en el territorio cisplatino hasta huir en 1824 a Buenos Aires. Allí, organizó y lideró la llamada "Cruzada Libertadora" que en 1825 culminó con la Convención Preliminar de Paz en 1828, y la posterior independencia del Uruguay en 1830. Fue candidato a presidente en 1830, elección que perdería frente a Rivera. Fue uno de los fundadores del Partido Blanco.
} 
como "La revolución de las lanzas" (1870-1872). ${ }^{227}$ Bauzá se opuso a ella porque pensaba que generalmente, durante las guerras civiles, se abrían las puertas a las intervenciones extranjeras, debilitando la nación. Por ende, se alejó de los dos bandos políticos enfrentados, acercándose al Partido Radical (integrado entre otros por José Pedro Varela [1845-1879] y José Pedro Ramírez [1836-1913]). Este alejamiento del Partido Colorado, y su visión contraria a las huestes revolucionarias, no fueron compartidos por Pivel quien, cuando lo creía necesario, fustigaba a Bauzá, basándose en su propio relato historiográfico como defensor de los partidos políticos tradicionales. En ese punto Pivel se apartaba de la (supuesta) objetividad del relato historiográfico, permitiéndose algunas opiniones:

\begin{abstract}
Resulta extraño que un hombre tan agudo para descubrir y analizar las causas generadoras de los problemas sociales y políticos, no fuera capaz de advertir que el movimiento revolucionario de 1870 era la expresión del drama de los partidos que luchaban por encontrar una fórmula que hiciera posible su coexistencia legal y pacífica (Pivel, 1965, pp. 40-41).
\end{abstract}

La lucha para la coexistencia de los dos bandos protagonistas estaba vista en clave teleológica. Pivel encontraba en el enfrentamiento de 1870 un antecedente a la nueva política de integración, en años donde se pensaba que el ejecutivo colegiado ${ }^{228}$ era la expresión constitucional y de gobierno que mejor plasmaba esa idea integracionista. Sin embargo, lo que sí resultaba extraño era que se criticaba a Bauzá sesenta años después (condescendientemente, es cierto) por no haber podido imaginar un Uruguay particularmente integrado (¿y pacífico?).

En consecuencia, la figura de Bauzá era mostrada por el prologuista como la de él mismo: un hombre que estuvo por encima de sus sentimientos de partido, siempre y cuando éstos no dañaran sus principios de libertad y de unidad nacional.

En el capítulo "El historiador y el pedagogo", Pivel se centró especialmente en la tarea historiográfica de Bauzá y en su discurso hegemonizante, buscando reafirmar la nación frente a aquellos enemigos que la contradecían. ${ }^{229}$

\footnotetext{
${ }^{227} \mathrm{La}$ Revolución de las Lanzas fue un enfrentamiento desarrollado entre 1870 y 1872 , que enfrentó al ejército gubernista del entonces presidente de la República Lorenzo Batlle (1810-1887) con las huestes del caudillo Timoteo Aparicio (1814-1882), de filiación blanca. El conflicto terminó luego de la firma de la Paz de Abril, en la que se estableció la coparticipación política al asegurar que parte del país (cuatro departamentos) quedaría bajo el mando de los blancos.

${ }^{228}$ En 1952, luego de un largo período de discusiones, se estableció una nueva constitución que instituía un Poder Ejecutivo compuesto por un colegiado de nueve miembros. En las elecciones generales, el partido ganador aportaba seis miembros y la minoría mayor los tres restantes. Esta reforma buscaba integrar a los dos partidos políticos más importantes, el Colorado y el Blanco, en caudal de votos.

${ }^{229}$ Es allí que se lo reconoce como antecesor en la tarea de realizar una historia de los orígenes del Uruguay a Juan Manuel de la Sota (Historia del Territorio Oriental del Uruguay de 1841, también editado por la Colección ... en 1965 con prólogo de Pivel), quien, según Bauzá y el mismo Pivel, fue el padre de la Historia nacional (Pivel, 1965, p. 204).
} 
Pivel acotó que la razón de ser de la Historia... se explicaba si se la consideraba «como una introducción amplia y documentada al conocimiento y comprensión de los orígenes», y que «fuera a la vez un alegato en favor de su supervivencia, la réplica a los anexionistas con añoranzas de un virreinato de creación tardía para unificar regiones que ya habían definido su individualidad» (Pivel, 1965, p. 210).

Recordemos que la discusión sobre la llamada "patria grande" se encontraba en plena efervescencia; el alegato en favor del nacionalismo imperante por sobre la unificación tardía dentro del Virreinato del Río de la Plata (en 1776) respondía a su tiempo, y correspondía a lo que Pivel también defendía. Bauzá y Pivel creían en la existencia real y determinante de la nación uruguaya, y sostenían que la corta existencia del virreinato no justificaba el alegato en favor de la unificación regional.

Posteriormente, apuntando a sus enemigos de forma directa, y siguiendo el racconto de los distintos acontecimientos fundadores de la nacionalidad, Pivel recordaba que, con respecto a la Cruzada Libertadora de $1825,{ }^{230}$ Bauzá se manifestaba en franca oposición a lo expuesto en 1879 por Juan Carlos Gómez (1820-1884). Gómez sostenía que los representantes de la Asamblea del 25 de agosto tenían pretensiones anexionistas a las Provincias Unidas. ${ }^{231}$ Como sabemos, también Pivel consideraba errónea esa perspectiva.

Pivel recordaba cuando Bauzá fustigó a Juan Carlos Gómez en la Historia... («Acierta Bauzá, cuando afirma...»), acusándolo de desconocer la historia nacional, siendo incapaz de ubicarse en el escenario político, por su apoyo al Partido Conservador, ${ }^{232}$ al que tildó de «revoltoso y anárquico» (Pivel, 1965, p. 234). También agregó, luego de una larga cita, ${ }^{233}$ que Bauzá

\footnotetext{
${ }^{230} \mathrm{~A}$ la Cruzada Libertadora se la conoce historiográficamente como una de las luchas por la liberación llevadas a cabo contra la ocupación brasileña del suelo oriental, que finalizaron en 1828 con la firma de la Convención Preliminar de Paz. Tuvo su inicio con el Desembarco de los Treinta y Tres Orientales, cuando el grupo acaudillado por Juan Antonio Lavalleja y Manuel Oribe cruzara desde el delta del río Paraná hasta la playa De la Agraciada, en el actual departamento de Soriano, el 19 de abril de 1828.

${ }^{231}$ Existe hasta el día de hoy una discusión en relación con una de las tres leyes promulgadas (independencia, unión y pabellón) por la Asamblea del 25 de agosto de 1825, conocida como la Ley de Unión. En ella se expresa que «... Queda la Provincia Oriental del Río de la Plata unida a las demás de este nombre en el territorio de Sud América, por ser la libre y espontánea voluntad de los pueblos que la componen, manifestada en testimonios irrefragables y esfuerzos heroicos desde el primer período de la regeneración política de dichas Provincias» (Castellanos, 2011, p. 49). A raíz de este texto, se pueden ver diferenciadas dos posturas, representadas por Gómez (deseos anexionistas de los cruzados), y por Bauzá (deseos independentistas, pero coaccionados por la coyuntura). ${ }^{232}$ El Partido Conservador fue fundado luego de la Guerra Grande (1839-1851), y pretendió «conservar» los ideales del llamado gobierno de la Defensa. Fue un grupo escindido del Partido Colorado.

${ }^{233}$ Pivel citó a Bauzá en una serie de artículos titulados La Independencia del Uruguay, publicados en el diario La Nación de Montevideo entre el 30 de setiembre y el 4 de octubre de 1879, en donde señaló que «la República del Uruguay es independiente por el esfuerzo de sus hijos y contra la voluntad de sus dominadores intrusos. San José y Las Piedras demostraron que no queríamos ser españoles; Guayabos y Cagancha que no queríamos ser argentinos. Haedo y Sarandí que no queríamos ser brasileños. Las combinaciones diplomáticas y aun las vistas particulares de propios y extraños, se estrellaron durante todo el largo período de la lucha por la independencia, contra estas determinaciones airadas de la voluntad nacional, triunfando por último el pueblo, que era quien había preparado, perseguido y alcanzado la conquista de su emancipación política» (Pivel, 1965, p. 235).
} 
...destruye la tesis peregrina del Dr. Gómez de que nuestra independencia fuera el resultado de una concesión graciable hecha por el gobernador Manuel Dorrego y el Emperador Pedro I y demuestra cómo la segunda ley dictada [...] [el] 25 de agosto de 1825 que declaró la incorporación del país a las Provincias unidas, no podía servir de fundamento a la pretensión de Juan Carlos Gómez para arremeter cuarenta años después contra la realidad configurada por el país independiente y constituido (Pivel, 1965, p. 235).

Siete páginas más adelante, volvía sobre el mismo tema, con nuevas citas y golpes contra la tesis anexionista de Gómez, quien al iniciarse el capítulo dedicado a la faceta de historiador del propio Bauzá, ya había sido castigado, junto a Francisco Berra. Gómez fue visto por Pivel como un enemigo, adhiriendo así a la perspectiva de Bauzá.

Respecto a Berra (el otro autor de la «leyenda negra» artiguista), en la tercera edición del Bosquejo histórico (1881) que figura en su biblioteca personal, solo existe una anotación hecha por Pivel, que parece una advertencia respecto del tratamiento de la figura de Artigas: «Al referirse al Bosquejo Bauzá dijo en el prólogo de la historia que Berra había hecho bien en "no emprender el retrato, pues con el bosquejo sobra para muestra pág. LVI"» ${ }^{234}$ Una simple frase de Bauzá desterraba una obra que fue prohibida en años de su edición. La anotación funcionaba como recordatorio y como advertencia, pero esta marginalia volvió a aparecer en la obra que escribió Pivel. Haciendo un racconto de las críticas de Bauzá a quienes se dedicaron a escribir sobre Artigas, citó nuevamente lo anotado por él en el libro de Berra (Pivel, 1965b, p. 132).

Para hacer frente, en el terreno historiográfico, a los casos citados, había que contradecirlos con pruebas contundentes. La construcción y el enfrentamiento de posturas fue moldeando el campo historiográfico. La reedición de ciertas obras, y el olvido de otras, tuvo como objetivo hegemonizar la discusión, tensando la vara hacia el lado de la conformación nacional.

\section{La justificación literaria: Zorrilla de San Martín y la construcción de la patria}

Como hemos expuesto antes, la justificación del proyecto canónico corrió por dos vías paralelas: la literaria y la historiográfica. La conformación del canon literario supuso situar en el centro a Zorrilla de San Martín (1855-1931). La Colección... terminó de oficializar esa elección,

\footnotetext{
${ }^{234}$ Esta referencia parte de la primera edición de la Historia de la dominación... (1895) que tuvo Pivel en sus manos. La marginalia se encuentra en Berrra, F. (1881). Bosquejo histórico, Biblioteca Pivel Devoto, Universidad de Montevideo.
} 
gestada desde la crítica literaria anterior y contemporánea al período estudiado. ${ }^{235}$ La insistencia en este poeta permitía consolidar su dimensión "nacional", estabilizando el canon.

En este segmento estudiaremos el prólogo que hizo Pivel, durante su estancia en el Ministerio, a una obra de Zorrilla de San Martín. Cabe destacar que, de toda la serie de prólogos que Pivel realizó durante su etapa ministerial (entre 1963 y 1966), éste es el único de una obra literaria. ${ }^{236}$

La literatura fue dentro de la Colección... el género más representado y sobre el cual se apoyó mayoritariamente la identificación sociocultural del país, ${ }^{237}$ probablemente porque otorgaba, como señala Anderson (2011), fuerte identificación nacionalista. Como dijimos anteriormente, si bien la Historia sería la que daría un sustento documental y veraz a las afirmaciones nacionales, el colorido de los acontecimientos y la fuerza afectiva de la adhesión nacionalista estarían a cargo de las obras literarias. A finales del siglo XIX, Zorrilla de San Martín y Acevedo Díaz fueron quienes mejor ejemplificaron la íntima relación que se buscó entre ambas disciplinas. Durante el mismo período, Bauzá y Carlos María Ramírez hacían lo suyo, pero del lado historiográfico. En todos los casos, el protagonista era el mismo: José Artigas.

Según Aínsa (2003), existen dos obras de referencia para sintetizar la identidad nacional: Ismael y La epopeya de Artigas. En el primer caso, la obra de Acevedo Díaz fue publicada en el tomo 4 de la Colección... y correspondió a la primera tanda de publicaciones — se terminó de imprimir en 1953, junto con nueve tomos más. ${ }^{238}$

Una vez que Pivel asumió la dirección de la Colección... decidió editar y prologar la obra que faltaba: La Epopeya de Artigas (en cinco tomos).

Zorrilla de San Martín fue un hombre de letras y de constante participación política. Su ardua tarea periodística y su talento como escritor, además de su actividad en la administración pública, lo hicieron ideal para encargarse de la construcción de un imaginario poético en torno a Artigas y a la Patria.

Como ya hemos dicho, la Comisión de la Colección... editó ampliamente a Zorrilla de San Martín, que es hasta el día de hoy el autor que cuenta con el mayor número de volúmenes, un total de $13 .{ }^{239} \mathrm{Su}$ papel estructural en la construcción del canon nacional hizo que el Ministro

\footnotetext{
${ }^{235}$ Ver el Capítulo 6.

${ }^{236}$ Cabe destacar que no va a ser el único sobre un libro de literatura, ya que más adelante en 1981 prologará el Parnaso oriental - como veremos páginas más adelante-, pero en ese caso fue elegido por la comisión de la Colección... ya que no se encontraba más en la presidencia, debido a no ocupar un puesto ministerial y estar bajo la dictadura cívico-militar.

${ }^{237}$ Setenta tomos sobre 167 estudiados (1953-1982).

${ }^{238} \mathrm{El}$ prólogo fue hecho por Roberto Ibáñez, director del INIAL.

${ }^{239}$ Se editaron: Tabaré (1956), La Epopeya de Artigas (1963) en cinco tomos, Conferencias y discursos (1965), Ensayos (1978) en tres volúmenes y La Leyenda Patria (1979).
} 
de Instrucción Pública asumiera la redacción del prólogo. Según contaba Pivel, el poeta ayudó con su obra a fortalecer la conciencia nacional, siendo de las mejores logradas de la literatura uruguaya. Además, consideró que Zorrilla de San Martín fue un

\begin{abstract}
...autor que había incorporado a la memoria del pueblo el recuerdo idealizado de la raza aborigen, al tribuno que había interpretado durante más de medio siglo los sentimientos colectivos, predominó, por sobre esos y tantos otros títulos y méritos indiscutidos, un hecho fundamental: con su pluma Zorrilla de San Martín había contribuído a erigir el monumento a Artigas. Él era quien había devuelto al pueblo oriental la imagen fiel del caudillo fundador. Antes de que la crítica lo reivindicara de los cargos con que lo había deformado la calumnia, anticipándose a la labor de los eruditos y a las pruebas surgidas de las contribuciones documentales, Zorrilla de San Martín había intuído a Artigas como la figura central de nuestra historia (Pivel, 1963b, pp. 7-8).
\end{abstract}

Como resaltara Pivel, Zorrilla de San Martín fue el primer y más efectivo defensor de la memoria artiguista. El poeta tuvo bajo su pluma mucho más éxito que el discurso historiográfico, que años después se encargó de justificar y moldear la imagen de Artigas como el caudillo fundador del pueblo oriental — aún huérfano de héroes neutros- - Recordemos que esta caracterización que hizo Pivel, sobre la obra de Zorrilla de San Martín, era coherente con el planteo de separación de los dos discursos reafirmando el carácter complementario de la literatura y la historiografía.

Además, según lo señalado por el prologuista, el poeta «había incorporado a la memoria del pueblo» una postal donde el indígena se vería idealizado por los cantos de sus obras. La adjetivación es interesante: al pretender idealizar a los charrúas, Zorrilla de San Martín describió a los indígenas mejores de lo que fueron, integrándolos al Uruguay como un recuerdo conectado con las raíces y que no generaba molestias, y desestimando la problematización respecto del origen conflictivo que tuvo el Uruguay en relación con ese tema.

Por lo tanto, según afirmaba Pivel, en la memoria del pueblo se había extirpado al indígena y, más que nada a los charrúas, que fueron expulsados del país en 1831 luego de la matanza de Salsipuedes. Una doble muerte, fáctica y simbólica. ${ }^{240}$

Si en la mneme (como memoria pasiva) del pueblo uruguayo, el indígena no tenía lugar, era necesario un tribuno para recuperar esa memoria a través de la anamnesis (como memoria activa), y a eso se refería Pivel. ${ }^{241}$

\footnotetext{
${ }^{240}$ Habrá una resurrección posterior con el best seller -extraño éxito con más de 23.000 ejemplares vendidos en diez años (Quiring 2016) - iBernabé!, ;Bernabé! (1988) del escritor Tomás de Mattos.

${ }^{241}$ Sobre las relaciones entre memoria e historia: Ricoeur (2013).
} 
Las relaciones entre Historia y memoria han sido un importante tema de reflexión desde mitad del siglo XX. ${ }^{242} \mathrm{Si}$ consideramos la Historia como discurso crítico del pasado, y la memoria como un conjunto de recuerdos individuales o colectivos, se entiende por qué la Historia ha querido separarse de la segunda, pero sin perder del todo su referencia como cantera para construir su relato. Por lo tanto, Pivel entendía que la mejor manera de gestar el sentimiento nacional no debía basarse únicamente en la historiografía, sino en la poesía, porque proporcionaba una memoria acrítica y colectiva más efectiva para el proyecto cultural nacional pretendido desde el Estado uruguayo.

Según Pivel, «Zorrilla de San Martín había intuido a Artigas como la figura central de nuestra historia» (Pivel, 1963b, p. 8). Esta representación no dejaba de ser un cliché, donde el poeta era un ser sensible que podía captar las esencias. Si fue Zorrilla de San Martín quien introdujo a Artigas como personaje en la historia nacional, su valor no solo se debía a sus atribuciones como poeta, sino también a los del intelectual que buscó crear una imagen que sirviera al país para asentar su nacionalismo naciente.

Si la nación cultural fue levantada desde sus cimientos por la escritura literaria, el fin de su construcción correspondió a la comunidad historiográfica - inicialmente integrada por los políticos de los primeros años de vida independiente del Uruguay, durante el siglo XIX—. En un lento avance, dicha comunidad comenzó a formarse con historiadores, primero predominantemente amateurs, luego como ejecutores de trabajos dentro de la administración estatal y finalmente como profesionales. ${ }^{243}$

Si bien las obras sobre Artigas fueron llevadas adelante por investigadores de la talla de Bauzá, Ramírez y Clemente Fregeiro, fueron Zorrilla de San Martín y Acevedo Díaz quienes dotaron de humanidad al bronce que se proyectaba forjar. Pivel reconoció que Zorrilla de San Martín, junto a Bauzá, José Pedro Pintos y Acevedo Díaz, fueron los encargados de «descorrer el velo de impostura que presentaba a Artigas con caracteres siniestros» (Pivel, 1963, p. 11).

Vayamos entonces al ejemplo más emblemático: La epopeya de Artigas fue la obra más representativa de Zorrilla de San Martín. ${ }^{244}$ Para escribirla, el poeta necesitó basarse en estudios previos de algunos investigadores - que en su mayoría integran la Colección ... - como Bauzá, Ramírez, Fregeiro, Maeso, De María, Eduardo Acevedo y Barbagelata, además de relatos de viajeros, memorias y documentación que tuvo a su alcance. Allí donde al tribuno nacional no le alcanzó el «conocimiento histórico», lo sustituyó por «intuición poética» (Pivel, 1963b, p. 28).

\footnotetext{
${ }^{242}$ Ver Ricoeur (2013) y Traverso (2012).

${ }^{243}$ Ver Zubillaga (2002 y 1996), Sansón (2006 y 2011) y Ribeiro (1991 y 1994).

${ }^{244}$ Recuerda Pivel que este libro fue un pedido del presidente Claudio Williman y dos de sus ministros entre 1907 y 1909, para ilustrar a los artistas encargados de hacer el monumento a Artigas.
} 
Pivel propuso un nuevo título al libro: La epopeya del pueblo oriental. Justificó que la obra contaba la historia de

...cómo un conglomerado disperso se transformó en una comunidad consciente de su ser, cómo se afirmó en gestos inviolables y originales bajo la palabra de un taumaturgo que formó su conciencia política; en fin, cómo nació la Nacionalidad Oriental (Pivel 1963b, p. 33).

La formación de la conciencia política del uruguayo estaría dada por la acción de sus poetas más que por la de sus historiadores. El historiador sería la fuente de inspiración del poeta para que éste transmitiera el mensaje al pueblo.

En otro pasaje, afirmaba Pivel que, cuando miraba el monumento hecho por Angelo Zanelli en la Plaza Independencia ${ }^{245}$, se sentía maravillado:

\begin{abstract}
Alguien, pensaríamos, inspiró la fuerza histórica de ese gesto arrogante, de esa alma sin dobleces, poseedora, a la vez, del secreto de la acción y de los sueños. Sí, seguramente lo habríamos adivinado. Una documentación fría jamás habría bastado para poner a un artista, ya un artista extranjero, en posesión de tantos secretos, de tantos matices de nuestro ser y de nuestra historia. Era necesario que alguien le diese conceptos envueltos en palabras musicales. Alguien que fuese, a la vez, patriota y poeta, capaz de sentir y transmitir emociones. Una voz cordial y humana. Alguien, en fin, como Zorrilla de San Martín (Pivel, 1963b, p. 28).
\end{abstract}

El tratamiento del documento histórico como algo frío denotaba, en parte, la posición historiográfica piveliana. Parecía que la única manera de escribir la historia era desde un discurso distante y objetivo, en fin, verdadero pero no más real. Si ese era el sentido que el historiador debía dar a la redacción del texto histórico, era coherente que la literatura dotara de más vida a los diferentes personajes que formaban parte de los acontecimientos y que creara así una adhesión emocional en el lectorado a la nación.

Nuevamente, Pivel utilizó y organizó la lectura que hizo de las obras para cohesionar su discurso historiográfico nacional. El origen y la formación de la nacionalidad era una idea recurrente en Zorrilla de San Martín, así como en Pivel. En sus comienzos, se encontraba el caudillo al que Pivel defendía, como ya vimos, historiográficamente:

En el pensamiento de Zorrilla de San Martín las patrias eran un instinto nacido de leyes históricas y sociológicas emanadas de una voluntad suprema; un hombre surgido de la entraña del pueblo acaudillaba esos instintos y luego era

\footnotetext{
${ }^{245} \mathrm{El}$ monumento fue inaugurado el 28 de febrero de 1923, y el joven Pivel estuvo presente como espectador en dicho acto (Vidaurreta, 2001).
} 
la multitud la que, identificando su alma colectiva con el alma del héroe, imponía al fin su voluntad (1963b, p. 27).

Esta constitución del caudillo, en palabras de José Pedro Barrán, como conductor conducido de la revolución independentista, fue el que pretendió perpetrarse en la figura de Artigas.

Sin embargo, Zorrilla de San Martín no fue el único autor literario trabajado por los prólogos pivelianos. Durante el período de la última dictadura uruguaya, tal como veremos a continuación, Pivel se encargó del estudio preliminar de la primera obra literaria uruguaya: $E l$ Parnaso Oriental. También se le encomendó la selección y prólogo de una serie de artículos historiográficos que remarcaron el sentido nacional y conservador que trazó el gobierno de facto.

\section{Cierre del proyecto editorial}

Al escribir el prólogo a El Parnaso Oriental o Guirnalda Poética de la República Uruguaya (1981), de Luciano Lira (?-1839), el historiador llevó adelante su último estudio previo hecho para la Colección..., antes de su irremediable alejamiento de la actividad administrativa por algunos años, debido a las negociaciones para la salida pactada de la dictadura cívico-militar.

Lo interesante del cierre de su etapa de prologuista fue la excusa que tuvo Pivel para reafirmar algunas ideas sobre la nación y los protagonistas de su construcción, además de las tareas de censor que los editores debían cumplir, al estar frente a un proyecto editorial de recopilación de obras. El contexto en que salió a la luz este prólogo tenía a Uruguay bajo la dictadura cívico-militar, y si bien en términos políticos el régimen había sido derrotado en las urnas, luego del plebiscito de noviembre de 1980, aún la crisis económica que pusiera fin a este oscuro período no había acontecido. ${ }^{246} \mathrm{Al}$ momento de llevar adelante su redacción, Pivel no sabía que sería su último prólogo.

Recordemos, hubo tres tópicos, fuertemente marcados, entre los temas propuestos por Pivel para la defensa de su postura historiográfica, en de los prólogos de la Colección...: la nación, la independencia del Uruguay - hija de la Cruzada Libertadora-, y los partidos políticos basados en el caudillismo, como punto de partida de la construcción del nuevo país y como origen de la futura coparticipación.

El orden del prólogo fue el mismo que siguió Pivel durante toda su estancia como intelectual al servicio de la Colección... Inicialmente, llevó adelante un estudio de los

${ }^{246}$ Ver Demasi y otros (2009) 
antecedentes de El Parnaso... ${ }^{247}$. Luego ubicó al autor dentro de su contexto histórico, sus redes intelectuales y su relación con la publicación de la obra. La idea era destacar algunos aspectos de la carrera pedagógica que tuvo Lira y su vinculación con la creación de la nación. ${ }^{248}$

Además de señalar su calidad de obra pionera, Pivel consideraba que El Parnaso... cumplía con el principal propósito para el cual estuvo pensado y construido: el fomento del imaginario nacional del novel país. También el prologuista pretendió destacar, sobre el trabajo de Lira, que

... los tres tomos de El Parnaso fueron publicados sin sujeción a ningún criterio. A la heterogeneidad del conjunto se suma la ausencia de un plan orgánico en lo que atañe al orden en que se suceden. Pero es evidente que el compilador Luciano Lira y quienes lo asesoraron se dieron a esta tarea con el propósito de ofrecer al país una visión del proceso histórico del que había surgido la nacionalidad (Pivel, 1981, p. 32).

Los temas que tocaron las distintas composiciones fueron desde «la victoriosa resistencia opuesta por las ciudades del Río de la Plata a las Invasiones Inglesas de 1806 y 1807» (Pivel, 1981, p. 32), pasando por el período artiguista y de la Cruzada Libertadora y la paz de 1828, hasta las presidencias de Rivera y Oribe.

Además, Pivel consideró que, desde 1828 hasta 1830, «los poetas del Parnaso escribieron antes que los historiadores, al recoger en sus obras todas las manifestaciones del sentimiento colectivo. Fue en esta circunstancia que comenzó a adquirir nombradía Francisco Acuña de Figueroa...» (Pivel, 1981, p. 33).

Lira actuó como compilador, buscando seleccionar y trazar una línea cronológica que explicara a través de la poesía el nacimiento y la consolidación del nuevo país. ${ }^{249}$ La obra constó de tres tomos, que en el caso de la Colección... fueron publicados en dos volúmenes (números 159-160), impresos de manera facsimilar con los originales.

Pivel comentó que no olvidó lo que Lira omitió, a saber: algunas «piezas valiosas» de la época de Artigas que no le gustaban a la sociedad montevideana, obras de Bartolomé Hidalgo entre 1816 y 1822, los Diálogos gauchescos, entre otros (Pivel, 1981, p. 35). En este caso, se hizo referencia a la tarea editorial y de censor que tuvo que llevar adelante Lira, y que nos

\footnotetext{
${ }^{247}$ Pivel encontró su origen en La Lira Argentina de 1824, la Colección de Canciones Patrióticas de 1825 y en algunas publicaciones poéticas editadas en Montevideo durante el período entre 1829 y 1833.

${ }^{248} \mathrm{El}$ compilador del Parnaso... era natural de Buenos Aires, pero había llegado al otro lado del Río de la Plata para dedicarse a la enseñanza, luego de un paso por la milicia durante su juventud porteña. Fue ayudante en la Escuela Normal, junto a Juan Manuel de la Sota (Pivel, 1981, pp. 9-10), lo que lo emparentaba con otro de los publicados y prologados por Pivel en la Colección... Posteriormente, fundó El Ateneo, un establecimiento de primeras letras para niños y jóvenes. Gracias a la vinculación de los escritores de la época con el poeta pudo publicarse su obra en 1837 (Pivel, 1981, p. 9).

${ }^{249} \mathrm{El}$ punto de inicio se estableció durante las invasiones británicas de 1806 y 1807.
} 
recuerda lo hecho por el propio Pivel. El Parnaso... respondió a un proyecto editorial donde el compilador, de manera explícita e implícita, pretendió no molestar a los sectores dominantes de la capital ya que eran sus únicos potenciales lectores. Por ello, Pivel sintetizó que

Luciano Lira silenció el período artiguista porque en la década del treinta era un motivo polémico, excluyó Odas y Diálogos relacionados con la guerra del Brasil para no acentuar la derrota del Imperio y, en otros casos, mutiló composiciones o modificó su texto [...] para no zaherir a España y apaciguar las pasiones aún latentes entre los dirigentes de la ciudad y la tendencia popular de raíz caudillista (Pivel, 1981, p. 37).

Claramente, Lira actuó como lo había hecho Pivel durante su estancia como editor. La selección de textos cumplió fines diferentes y respondió a posturas políticas antagónicas. Por un lado, Lira pretendió editar una selección poética neutral, que no lesionara el sentimiento de ninguna de las colectividades ni las raíces políticas de integrantes del nuevo Estado. Por otro, Pivel pretendió unir y amalgamar, a través de un proyecto oficial nacional, esas diferentes posturas políticas ya afianzadas y existentes. Si bien hablamos de momentos diversos y separados en la historia cultural e intelectual del Uruguay, el estudio previo pretendió reparar en ellas y buscar juntarlas de forma indirecta.

A nivel historiográfico, Pivel volvió sobre otro de sus tópicos, al introducir nuevamente la discusión relacionada con las fechas de independencia del Uruguay, remarcando su postura, al identificarla en los demás autores como antecedentes válidos a su propio punto de vista sobre el tema. Como dijimos, según el prologuista, la fecha del nacimiento del Estado uruguayo tenía que ser la del 25 de agosto de 1825. En dicha fecha, Pivel consideró que se debió conmemorar correctamente la independencia del país, ya que fue cuando se constituyó un «gobierno patrio», que posteriormente formuló y promulgó la Constitución de 1830 (Pivel, 1981, p. 15).

Es más, según el mismo Pivel,

Los actos institucionales promovidos por la revolución de 1825 hasta la paz de 1828 habían sido difundidos ampliamente en el territorio uruguayo en el que ejerció sus potestades el Gobierno Patrio. [...] Para que la unidad política instituida por el Constituyente de 1830 se consolidara, era necesario que existiera una conciencia histórica. Un medio para alcanzarla consistía en llevar al conocimiento de todos los habitantes del país los sucesos militares e institucionales que culminaron en la paz de 1828. El 25 de agosto de 1833 «El Universal» y «El Investigador» habían publicado en Montevideo, el primero con reflexiones y comentarios muy expresivos, el texto íntegro de la Ley fundamental de 25 de agosto de 1825 que declaró la Independencia Nacional (Pivel, 1981, p. 16). 
Si hacemos caso a la precedente cita, no parece del todo clara a nivel historiográfico, la justificación del 25 de agosto como conmemoración de la independencia del Uruguay. Pero, lo que le importaba a Pivel era, en este caso, la confrontación de esa conciencia histórica nacional más que la exactitud historiográfica. Dicha necesidad de establecer un discurso veraz corría por parte de los historiadores, y estaba lejos de la formación del nuevo Estado. ${ }^{250}$

Pivel usó nuevamente el prólogo como vehículo para reafirmar su posición historiográfica sobre los sucesos de la independencia y para, con su triple poder de prologuista, editor e historiador, dejar asentada en las obras del Estado su visión sobre la nación uruguaya.

Pivel rememoró historiográficamente la génesis del enfrentamiento que dio inicio, según su postura, a los partidos políticos tradicionales del Uruguay. Es por ello que comenzó retomando lo sucedido en la batalla de Carpintería, y en los levantamientos del expresidente Fructuoso Rivera (Partido Colorado) contra el gobierno del presidente Manuel Oribe (Partido Blanco). La justificación que usó Pivel de manera indirecta fue que, durante esos acontecimientos, era editado el tercer tomo ${ }^{251}$ de El Parnaso... — con Lira nuevamente como compilador, con la ayuda de Francisco Acuña de Figueroa, e impreso en la Imprenta de la Caridad en 1837 (Pivel, 1981, p. 31)—. Existía, según comentaba Pivel, una relación entre la publicación de obras poéticas y la demostración del supuesto avance cultural del país. Si bien se citaba dicho parecer, el prologuista señalaba esa afirmación porque de alguna manera lo avalaba no solo para la obra estudiada, sino también por extensión, para el propio proyecto editorial que él representaba (Pivel, 1981, pp. 30-31).

Para cerrar el estudio crítico, Pivel eligió hacer referencia a la versión anterior que tuvo El Parnaso... antes de ser editado por la Colección.... ${ }^{252}$ En dicho caso, el cuidado del libro y el estudio preliminar estuvieron a cargo de dos integrantes de la red intelectual piveliana y amigos personales suyos: Mario Falcao Espalter y Gustavo Gallinal, a quienes rindió homenaje al finalizar su prólogo.

\footnotetext{
${ }^{250} \mathrm{La}$ discusión que emprendió Pivel se desencadenó por la aparición del «Himno al Sol de Julio de 1835 » incluido en el Parnaso..., que tomaba como nueva fecha de la independencia del Uruguay el 18 de julio de 1835 (Pivel, 1981, pp. 13-16), ya que es particularmente extraño y original tomar el año 1835 como la génesis del Estado autónomo e independiente.

Ahora bien, ¿qué motivaba que la fecha reseñada mereciera un himno? Es que en 1835 se cumplía el plazo establecido en el artículo 10 de la Convención Preliminar de Paz de 1828 donde tanto las Provincias Unidas del Río de la Plata como el Imperio del Brasil dejaban «en estado de perfecta y absoluta independencia» a la denominada Provincia de Montevideo (República del Uruguay). Según el mismo documento, si fueran a haber inestabilidades internas, ambas partes se habían comprometido a intervenir para auxiliar y conservar el gobierno legal que tuviera el nuevo país (Pivel, 1981, pp. 15-16).

${ }^{251} \mathrm{El}$ segundo tomo había sido editado en 1835, «en un ambiente en el que el espíritu de confianza en el futuro del país impulsaba todas las voluntades» (Pivel, 1981, p. 20). La aparición del nuevo ejemplar supuso según Pivel que «Sus numerosos suscritores al apreciar los méritos de las obras que formaban el volumen asociaban el esfuerzo editorial al progreso del país, de su cultura» (1981, p. 21).

${ }^{252}$ La edición había salido en 1927, impresa por el Instituto Histórico y Geográfico del Uruguay, al que perteneció posteriormente Pivel como director.
} 


\section{Conclusiones parciales}

El estudio de los prólogos de Pivel llevado adelante aquí nos demuestra la importancia que tenía este dispositivo de control de lectura para la Comisión Editora de la Colección... y para el Estado nacional.

No solo la selección del redactor del estudio previo era importante, sino también aquello que decía en relación con la obra que se estaba presentando. En el umbral, como lo llamaba Genette, se exponían las ideas sobre la nación uruguaya, principal tema de interés.

Pivel tuvo la posibilidad de ser uno de los prologuistas más dominantes. La variedad de autores, géneros y tipos de obras lo convirtió en el más variopinto de todos los redactores. Claramente, esta función que pudo ejercer nuestro protagonista era hija de su posición de poder ejercida durante su larga carrera en la administración pública y sus vinculaciones políticas partidarias que le permitieron ser ministro de Instrucción Pública, y por tanto, director de la Colección...Pivel usó estos prólogos para hacer Historia y discutir ideas sobre la misma, afianzando su propia postura historiográfica sin mencionarla directamente.

Esa posición hegemónica fue aprovechada enteramente por Pivel. Durante los años sesenta, como ya hemos expuesto, se editaron como nunca tomos dentro de la serie de libros que estamos estudiando y, por lo tanto, se multiplicó la cantidad de prólogos a redactar.

El historiador nacional puso manos a la obra, y no solo dotó a la Colección... de un catálogo a imagen y semejanza de la idea de nación piveliana, sino que además, desde los prólogos, terminó de imponer su marca simbólica e interpretativa sobre todo lo editado.

Pivel pretendió (a través de su actividad administrativa, de su derrotero intelectual y de sus consecuentes apreciaciones críticas) resaltar las bases que justificaban el nacimiento de la nación uruguaya desde el punto de vista histórico y literario - completando así la conformación de una comunidad imaginaria de lectores, en el sentido de Anderson, 2011-, no es causal entonces que, a nivel general, el nacionalismo haya sido el tema que atravesó casi todos los prólogos que escribió.

Tal como creemos, la visión de la nación que se tejió desde el Estado, a través de la tarea intelectual de Pivel $-\mathrm{y}$ especialmente, por medio de la Colección... - fue claramente conservadora, desatendiendo las experiencias artísticas contemporáneas.

El estudio que hemos desarrollado intentó demostrar cómo la construcción de la nación cultural — historiográfica y literaria para los casos que nos ocupan — fue conformándose desde múltiples aristas buscando consolidar un canon de unas obras y su interpretación. 


\section{CAPÍTULO 6 \\ EL CIELO CANÓNICO URUGUAYO Y LA COLECCIÓN...}

El canon es un concepto de disputa y discusión para la literatura. Las definiciones se han multiplicado de manera diversa dentro del espectro crítico, desde las posturas más conservadoras y cerradas hasta aquellas más proclives a la apertura y al cambio. La constitución de un canon supone seleccionar entre la diversidad o rescatar de la historia literaria a algunas obras, ¿pero cuáles?

Canon y poder se encuentran íntimamente unidos (Sullá, 1998). Para que el canon exista, aquel que lo constituye debe poseer algún tipo de poder — político, cultural, simbólico, social, económico - para disputar o hegemonizar el campo literario (Bourdieu, 1999).

Para canonizar a un autor se pueden utilizar diversas estrategias, desde la integración a una historia de la literatura, pasando por el estudio en los programas de enseñanza, o su publicación en antologías, colecciones y revistas. La existencia de un canon nacional está relacionada con la necesidad manifiesta de tener alguna certeza identitaria. La falta de un canon oficializado hacia el siglo Xx llevó al Estado uruguayo a consolidar uno.

En el caso de Uruguay, las obras que se eligieron fueron seleccionadas por críticos pertenecientes a las clases dirigentes, muchos de ellos con trayectoria política o con relaciones suficientemente importantes como para poder editar sus libros de Historia de la literatura. En este sentido, los casos de Roxlo y de Barreiro y Ramos son los más claros y sobre ellos volveremos en este trabajo. Con el correr del tiempo dichas obras críticas se transformarían en hegemonizantes aunque sin la definitiva aceptación simbólica del Estado nacional. El carácter oficial de los críticos literarios mencionados estaba dado por la pretensión de ser representativos en la conformación de la ciudadanía cultural nacional, y por cierto apoyo estatal en sus publicaciones. Como observaremos, algunas de las obras que buscaban definir el canon fueron apoyadas económicamente en su edición por el Estado.

Finalmente, una vez creada la Colección..., esos autores y obras fueron integrados al catálogo conformado por el Estado. Por lo tanto, consideramos que la serie de libros editados oficialmente tuvo una doble función: primero, laudatoria del canon ya conformado pero aún no consolidado $\mathrm{y}$, en segunda instancia, resignificativa, ya que interpretó las obras desde una 
mirada nacional cultural. Por lo tanto, escribir sobre lo canónico en la Colección... suponía, $a$ priori, hablar sobre lo homogéneo y ya determinado por otros críticos literarios.

En este capítulo, trabajaremos tres Historias de la literatura uruguaya que tuvieron carácter de oficiales antes de la existencia de la Colección.... Historia crítica de la literatura uruguaya de Carlos Roxlo (1912-1916), el Proceso Intelectual del Uruguay y crítica de su literatura de Alberto Zum Felde (1930, 1941, 1967), y la Historia sintética de la literatura uruguaya de Carlos Reyles (1931). Finalmente, observaremos que la confección del canon uruguayo oficial fue producto de un sistema de canonicidad, y sus frutos pueden observarse en la lista configurada por el proyecto editorial en que estamos trabajando.

\section{El Big Bang como génesis del primer canon}

Las diversas Historias de la literatura nacional estuvieron vinculadas al despertar de la conciencia nacional y de la unidad lingüística del territorio (Kuschner, 2002). Carlos Roxlo fue el primer crítico que llevó adelante global o panorámica de la literatura uruguaya y, por lo tanto, el que sentó las bases de lo que posteriormente llamaríamos el canon literario nacional.

Su Historia crítica de la literatura uruguaya (1912-1916) fue un estudio erudito que tuvo mucha influencia en los posteriores críticos literarios ${ }^{253} \mathrm{y}$ en las colecciones de libros contemporáneos a su edición. La obra de Roxlo fue tomada por el propio autor y su editor Antonio Barreiro y $\operatorname{Ramos}^{254}$, como una acción patriótica orientada al lectorado recientemente escolarizado («Nacionalizar la enseñanza de la literatura es labor patriótica»; Roxlo, 1912, p. 10), conformando a través de la cultura una caracterización literaria de la nación ${ }^{255}$.

Aquello que publicó Roxlo, gracias a la ayuda de Barreiro y Ramos, tenía dos objetivos: fomentar el conocimiento de los escritores que forjaron la literatura nacional a aquellas generaciones contemporáneas y futuras de lectores, y permitir, a través de la resignificación de sus obras, la nacionalización cultural del lectorado formado luego del éxito de la reforma escolar impulsada por los hermanos José Pedro y Jacobo Varela, y desarrollada durante el primer batllismo (1903-1929).

\footnotetext{
${ }^{253}$ Por ejemplo, es citada en cada una de las historias de la literatura uruguaya que vamos a estudiar.

${ }^{254}$ En las primeras hojas de la Historia crítica..., de aparición tardía para lo que fue el desarrollo histórico del país independiente, Roxlo tuvo palabras de agradecimiento para con su editor. El crítico literario entendía que sacar a la luz siete gruesos tomos era un esfuerzo económico muy importante para el país, que contaba con poco más de un millón de habitantes.

${ }^{255}$ La identificación que hizo Roxlo del terruño con el concepto de nación es coherente con la propia concepción histórica que tuvo Uruguay. La independencia fue primero territorial y, posteriormente, se necesitó la construcción de lo uruguayo como separación de lo argentino para dar una identidad propia a la nacionalidad.
} 
En la Historia crítica... Roxlo dividió la literatura uruguaya en tres períodos distintos. El primero denominado clásico o inicial (1810-1841); el segundo, romántico o romancesco (1841 y 1885), y para finalizar, el ecléctico o de transición, que iría hasta 1911, año en que fue finalizada la obra (Roxlo, 1912, pp. 24-25). Este tipo de división cronológica de la historia literaria propuesta por Roxlo supone un criterio de causalidad relacionado con su contexto histórico. Según el autor, las corrientes estéticas, obras y autores estaban directamente influidos por su entorno, sin explicar muy bien cómo, por lo que establecía un determinismo de impacto unilateral del contexto histórico sobre el hecho literario (Kuschner, 2002). Temporalmente, la obra avanzaba de manera homogénea, constante y dividida en partes muy definidas. Los cortes suponían un tratamiento del tiempo histórico literario de forma unidireccional y teleológico.

La cantidad de escritores estudiados por Roxlo fue abrumadora. Dentro de los períodos literarios y los distintos temas que investigó, dio cuenta de gran cantidad de literatos, oradores, políticos y demás intelectuales. La obra de Roxlo parecía tener como objetivo señalar todo lo que se había escrito. Sin embargo, al leer la integridad de la Historia crítica... sobresalen algunos nombres inmediatamente.

Los autores que resaltó Roxlo fueron a los que se les concedió un capítulo entero para su biografía y obra, con sus respectivas reseñas y estudios específicos. Dedicar una parte importante de la obra a algunos escritores seleccionados fue un destaque que inducía a entender la trascendencia observada por el crítico.

Roxlo abrió su libro con una carta-prefacio dedicada a su editor y mecenas, Barreiro y Ramos, donde configuró las bases sobre las que se apoyaron los siete tomos de su trabajo. Allí brindó la primera definición sobre la literatura del Uruguay. Preguntándose si existía realmente una literatura propia, el autor contestó que

Si la literatura es la expresión de los caracteres del genio de un país y de los ideales más acendrados de una nacionalidad, nuestra literatura, á pesar de lo galo de sus tendencias y de lo hespérico de su lenguaje, es hija de los pagos en que silba el zorzal y en que verdea el trébol, por la abundancia de poetas y de prosadores que describen los hábitos y traducen las ansias del terruño. En sus asuntos, como también en sus tropos y en sus modismos, nuestra y muy nuestra es la musa de Figueroa, Magariños Cervantes, Acevedo Díaz, Juan Zorrilla de San Martín. Si esto, que es mucho, nos supiese á poco, ¿no nos pertenecen los discursos de Carlos María Ramírez? ¿No nos pertenecen las obras jurídicas de Jiménez de Aréchaga? ¿No nos pertenece la labor económica de Eduardo Acevedo? ¿No nos pertenecen los artículos de costumbres de Daniel Muñoz? ¿No nos pertenecen las descripciones de Marcos Sastre? Y si esto aun no bastase, ¿no es nuestra, por ventura, la «Beba» de Reyles? ¿No es nuestro, por ventura, el «Gurí» de Viana? ¿No son nuestras las cantadoras décimas de Regules? ¿No es nuestra, en fin, la musa teatral de 
Florencio Sánchez? Existe, pues, —con caracteres firmes y diferenciales-, una LITERATURA URUGUAYA (Roxlo,1912, pp. 7-8). ${ }^{256}$

La descripción y justificación que realizó el crítico hizo referencia al concepto extendido de que ésta, según sus palabras, sería todo lo escrito en un país. ${ }^{257}$ Roxlo consideraba que era necesario integrar al canon no solo a los escritores de las belles lettres, sino también a juristas, historiadores, políticos y demás intelectuales que permitieran asentar características esencialmente relacionadas con la idea de nación uruguaya, separada de otras expresiones consideradas foráneas.

Por lo tanto, y remitiéndonos a la cita precedente, observamos que Roxlo pretendía justificar los orígenes de la nación cultural uruguaya, exponiendo el nombre de los pioneros en cada una de las expresiones artísticas consideradas dignas de mención. Sin embargo, esos supuestos gérmenes de nacionalidad que cada uno de los autores poseían, chocaban con su contexto social, ideológico, político, y con sus respectivas posibilidades históricas.

Que Roxlo haya querido conectar su presente histórico con expresiones literarias de principios de siglo XIX, y ver en ellas los inicios de la nación aún no constituida, negaba varias de las opciones existentes dentro del horizonte de posibilidades que cada uno de los actores poseían durante el desarrollo de sus respectivas obras ${ }^{258}$.

Yendo al estudio tomo por tomo observamos que Roxlo dedicó en su primera entrega ${ }^{259}$, además de los autores considerados como los pioneros en cada uno de los estilos literarios, un capítulo entero a Juan Carlos Gómez ${ }^{260}$, honor compartido con Acuña de Figueroa.

En el segundo volumen, cuatro fueron los autores estudiados en detalle: en primer término, dos literatos como Magariños Cervantes y Zorrilla de San Martín y, en segunda instancia, dos historiadores defensores del artiguismo e integrantes de las redes intelectuales de Roxlo como Ramírez y Bauzá. ${ }^{261}$

\footnotetext{
${ }^{256}$ Mayúsculas en el original.

${ }^{257}$ Debemos decir, que salvo el caso de Marcos Sastre y de Eduardo Acevedo, todos los autores nombrados fueron editados por la Colección..., lo que demuestra una cierta consonancia con lo expresado en la cita y una primera enunciación del canon literario.

${ }^{258}$ Existían perspectivas políticas españolistas, revolucionarias, carlotistas, extranjerizantes, antiartiguistas, proporteñas, entre otras, que derivarían en otras opciones para el territorio en cuestión - entre las que la independencia no era necesariamente una de ellas-.

${ }^{259}$ Respecto a las fuentes usadas por el autor, para hablar del período colonial tanto a nivel histórico como literario, Roxlo se basó mayoritariamente en Bauzá, a quien conocía personalmente y con el cual compartía reuniones en la tertulia de Barreiro (ver capítulo 3). Las obras que fueron fundamentales para el desarrollo de su estudio fueron la Historia de la dominación... y los Estudios históricos, aunque también en algunos casos echó mano a lo escrito por Magariños Cervantes, Andrés Lamas, Carlos María Ramírez y Francisco Berra (en su Bosquejo histórico...). ${ }^{260} \mathrm{El}$ erudito, periodista y político colorado, fue excluido conscientemente de la Colección ..., debido a sus errores de apreciación para con el artiguismo, que le costaron muy caro como para ingresar al canon estatal.

${ }^{261}$ Todos estos autores fueron editados posteriormente por la Colección.... En este caso, el nombre que sobresale es el de Zorrilla de San Martín. La importancia simbólica del poeta ya será marcada desde las páginas de la Historia crítica ... y será notablemente resaltada en las distintas entregas de su obra en la Colección..., siendo el autor más editado hasta el momento.
} 
En el cuarto tomo, se dedicó un capítulo a Carlos Reyles, que mostró ser otro de los escritores que concitó la unanimidad dentro de la crítica literaria. Finalmente, en el tomo seis, podemos observar que existen sendos capítulos sobre Florencio Sánchez y Javier de Viana, mientras que en el último volumen, Herrera y Reissig, Frugoni y Vasseur son los otros destinatarios de los estudios de Roxlo. ${ }^{262}$

Al hacer el análisis de la Historia crítica ... encontramos las bases del canon posterior: se inscribió en el firmamento literario la primera constelación sobre la cual el resto de los críticos analizados remarcaron su trascendencia, pues los escritores centrales en la obra de Roxlo fueron Hidalgo, Magariños Cervantes, Reyles, de Viana, Sánchez, Herrera y Reissig, Frugoni, Vasseur, y en el centro del canon, Zorrilla de San Martín.

\section{El Proceso de Zum Felde}

En el caso de Alberto Zum Felde ${ }^{263}$, su obra más importante fue el Proceso intelectual..., editada en 1930 y reimpresa dos veces más. Esta serie de libros sirvió de referencia para otros críticos de la literatura, sobre todo para los autodenominados integrantes de la Generación crítica. En los tres tomos se analizaban algunos autores considerados fundamentales para la literatura nacional.

La obra de Zum Felde debe ser resaltada, ya que implicó un importante estudio panorámico de las letras nacionales, el segundo en extensión y pretensiones - luego del de Roxlo-. Además, se trataba de un crítico que se mantuvo en actividad hasta los años setenta, integrando el staff del semanario Marcha y también como prologuista de la Colección...

Debemos recordar que la edición de esta obra fue subvencionada por el Estado uruguayo, al conmemorarse el centenario de la Jura de la Constitución de 1830, lo que le daba cierta oficialidad a su planteo. Respecto del crítico, como veremos, ${ }^{264}$ formó parte de la nómina de prologuistas habituales de la Colección...

El Proceso intelectual... contaba con una nómina de autores reseñados que estaban ligados a lo histórico gracias a ser integrantes del campo político, con el agregado de algunos escritores dedicados a la literatura. Es que el autor creía, junto a Roxlo, que todo lo escrito en Uruguay formaba parte de la llamada literatura nacional.

Los tomos del Proceso intelectual... dividen a la historia del Uruguay en tres partes. En primer término, los integrantes de las primeras letras, que irían desde la colonia hasta el 1900.

\footnotetext{
${ }^{262}$ Debemos decir que todos los resaltados fueron editados posteriormente por la Colección...

${ }^{263}$ Sobre aspectos biográficos de Zum Felde hablaremos en el Capítulo 7.

${ }^{264}$ Ver el Capítulo 7.
} 
Entre los autores encontramos estudios específicos a Bartolomé Hidalgo, Francisco Acuña de Figueroa, Andrés Lamas, Adolfo Berro, Juan Carlos Gómez, Magariños Cervantes, Juan Zorrilla de San Martín y Eduardo Acevedo Díaz.

En segunda instancia, encontramos a los integrantes de la llamada Generación del Novecientos hasta la Generación del Centenario, en la que observamos nombres como los de José E. Rodó, Julio Herrera y Reissig, Florencio Sánchez, Javier de Viana, Delmira Agustini, María Eugenia Vaz Ferreira y Carlos Reyles.

Finalmente, los más cercanos temporalmente a la edición del Proceso intelectual... son reunidos en capítulos dedicados a la poesía, a la nueva generación literaria y a los escritores actuales. El único caso tratado individualmente fue el de Carlos Vaz Ferreira, quien debido a su prestigio intelectual durante los años treinta — aunque fue filósofo y no literato- era difícil no mencionar.

Esas figuras centrales estaban acompañadas de otros autores que componían de manera mucho más numerosa la periferia canónica. Al final del tercer tomo, Zum Felde estableció un índice de autores. Allí, encontraremos cuatro categorías en las que dividió la literatura nacional: poesía, lírica y épica (con 72 autores); novela, cuento y crónica (con 25); teatro (con 15), y filosofía, ensayo y crítica (con 39).

Si sumamos a Reyles, nuestro tercer crítico trabajado, ya podríamos despejar ciertos nombres para delimitar nuestro "cielo" literario.

\section{El sintético Carlos Reyles}

La Historia sintética... (1931), es una compilación editada por Alfredo Vila y con una extensión de tres tomos, fue una obra basada en conferencias realizadas por diversos profesores y críticos de literatura, donde se trabajaron los autores considerados más importantes del Uruguay, al cumplirse el centenario de la Jura de la Independencia.

El autor de estos libros es Reyles, el creador del plan de estudios para la educación secundaria $^{265}$ aprobado por el Estado en 1930, cuando era asesor literario y artístico de la Comisión Nacional del Centenario. Las distintas conferencias fueron transmitidas por la radio del SODRE y, por su importancia para las letras nacionales, se decidió su publicación en tres volúmenes.

Cada uno de los capítulos llevó el nombre del autor sobre el que trataba la charla y, en general, se buscó que el interlocutor fuera un especialista sobre el tema o el autor trabajado.

\footnotetext{
${ }^{265}$ Que comenzó a funcionar de forma autónoma en 1935 bajo el nombre de Consejo de Educación Secundaria, separado de la Universidad de la República que era la institución encargada de los estudios secundarios.
} 
Dicha lista es de vital importancia para la construcción canónica, ya que es un antecedente válido llevado adelante por el Estado, y que además tuvo consecuencia directa en la conformación de los programas de literatura de la enseñanza pública, lo que refuerza el carácter oficial de esta obra canónica.

Debemos destacar que la extensión de la obra fue muy importante —más de 1100 páginas-, aunque se editó inconclusa, ya que, como dijo su editor,

\footnotetext{
Por haber resultado estériles todas las gestiones realizadas para obtener de sus autores la entrega de los originales, faltan las siguientes conferencias: «La Poesía Post-Modernista», primer grupo, sobre Carlos Sabat Ercasty y Emilio Oribe; y las que trataron sobre Zavala Muniz, Javier de Viana, Pérez Petit y P. Leandro Ipuche (Reyles, 1931, p. 2).
}

De todos los capítulos, resaltan algunas individualidades ya que en varias ocasiones se hicieron estudios panorámicos sobre el teatro, la narrativa, la poesía — divididos en algunos grupos como poetas tendenciosos, poetisas, la poesía posmodernista_-, la crítica y el ensayo. Estos escritores tratados específicamente serían, en algunos casos, los autores centrales del canon. Dentro de este círculo selecto, encontramos a Zorrilla de San Martín, Acevedo Díaz, Rodó, Herrera y Reissig, Agustini, Florencio Sánchez, Juana de Ibarbourou, Quiroga, Julio Supervielle y Maria Elena Muñoz — estos últimos dos, vistos como los nuevos autores para adosar y actualizar la nómina canónica-.

Debemos resaltar que, en esta lista, existió una fuerte presencia femenina en comparación con otras formas canónicas precedentes.

Debemos destacar que, si bien esta perspectiva panorámica no fue tan pretenciosa como las anteriores, al dar el preámbulo crítico al primer programa de literatura de enseñanza secundaria, terminó adquiriendo un grado de oficialidad que el resto de las obras reseñadas no tuvieron.

\section{El laudo en el catálogo de la Colección...}

La construcción del catálogo, y por tanto la configuración laudatoria del canon literario oficial, tuvo como base a aquellos escritores que ya eran de relevancia para el medio nacional. Como vimos, tanto autores como obras ya estudiados por las historias literarias fueron recogidos e impresos por el Estado uruguayo oficializando el canon nacional.

Dentro de la lista de autores considerados centrales para todas las fuentes antes relevadas, no encontramos grandes diferencias en la constelación canónica oficial. Justamente, Zorrilla de San Martín fue el más editado por la Colección..., con 13 volúmenes. 
El conformar el canon literario nacional era una tarea que implicaba integrar cada una de las obras y autores en una Historia de la literatura nacional. Además de generar dicha selección, era necesario una justificación erudita y una reinterpretación del significado de las obras a través de los prólogos, un ámbito que el proyecto estatal utilizó para referir de manera directa cuáles eran sus opiniones respecto a los autores canonizados. ${ }^{266}$

En cada uno de los estudios previos que trabajamos anteriormente, se encargaron de ensalzar de manera grandilocuente los nombres del centro canónico. El canon dentro de la Colección... agrupó a la mayoría de los autores centrales en la primera etapa de edición colorada, durante el período 1953-1957. En estos años se publicaron obras de Reyles, Acevedo Díaz, Zorrilla de San Martín, de Viana y María Eugenia Vaz Ferreira. Luego, durante el período piveliano (1963-1966), se editó el resto: Agustini, Quiroga, Herrera y Reissig y Sánchez.

Los críticos más importantes del país se encargaron de llevar adelante la justificación erudita del proyecto, prologando a los autores centrales del canon nacional. Ángel Rama se encargó de Reyles (El terruño y Primitivo, vol. 3), Roberto Ibáñez, de Acevedo Díaz (Ismael, vol. 4), Zum Felde, de Zorrilla de San Martín (Tabaré, vol. 18) y Herrera y Reissig (Obras poéticas, vol. 113), Arturo Sergio Visca, de De Viana (Gaucha, vol. 19 y Selección de cuentos, vols. 70-71) y de Reyles (Ensayos, vols. 84-86), Emir Rodríguez Monegal, de Acevedo Díaz (Nativa, vol. 53; Grito de gloria, vol. 54; Lanza y sable, vol. 63), de Quiroga (Selección de cuentos, vols. 101-102; Historia de un amor turbio, vol. 126), Walter Rela de Sánchez (Teatro, vols. 121-122) y de Reyles (Beba, vol. 62).

Llama la atención que, cuando se trató de autoras, la crítica que se hizo cargo de los prólogos fue la misma mujer: Esther de Cáceres. Claramente, existió una concepción de género en esta decisión, al considerar que solo una mujer podía hablar de otra, ya que compartían sensibilidades — además, de Cáceres era católica y conservadora, lo que agregaba cierta solemnidad a sus aportes-, diferentes a las de los hombres, lo que reafirma la perspectiva conservadora en las decisiones de edición.

\section{El centro del canon}

La base sobre la que se sustentó el canon oficial fue La leyenda patria (1879) de Zorrilla de San Martín. Por lo tanto, podríamos tomarla como la publicación pionera, enteramente dedicada a la nación y de tardía composición. Ya hacía cincuenta años que Uruguay había sido constituido como Estado, y casi nada de lo escrito durante los años previos fue considerado para integrar el

${ }^{266}$ Ver el Capítulo 5. 
canon. ¿Qué había pasado? ¿Ninguna obra llegaba a los estándares básicos para formar parte del canon de la literatura nacional?

Recordemos que, en realidad, la configuración nacional en términos históricos y culturales fue tardía. El Uruguay se construyó como nación sobre la base de la reforma vareliana y del período modernizador durante los gobiernos de Latorre y Santos, hacia los años 1860-1880. Significativamente, ver a Zorrilla de San Martín como tribuno de la patria, leyendo su poema en comemoración a la Declaratoria de la Independencia, era una imagen suficientemente potente en términos simbólicos.

Con relación a la serie de libros impresos por el Estado, La leyenda patria fue editada en 1979, cuando se cumplía el centenario de su primera edición. La introducción estuvo a cargo de Arturo Sergio Visca, quien fue director de la Biblioteca Nacional durante la dictadura. Además, el tomo contó con el estudio crítico de Eustaquio Tomé, cuyo texto ya había sido impreso anteriormente bajo el nombre de La leyenda patria. Su valor artístico y su significado histórico en $1952^{267}$ por el Instituto Histórico y Geográfico del Uruguay —institución que, como sabemos, tenía directa conexión con Pivel—. Sin embargo, la trascendencia histórica del autor fue trabajada por Pivel en un estudio previo ya reseñado. ${ }^{268}$

El volumen sobre Zorrilla de San Martín comenzaba con una reseña del momento en que se presentó al público. El poema La leyenda patria fue compuesta en siete días por el poeta nacional, y presentada al concurso que organizó el Estado uruguayo para inaugurar el Monumento a la Independencia en la ciudad de Florida, ejecutado por el escultor italiano Juan Ferrari. El ganador tendría la oportunidad de leer la composición a la concurrencia. Como Zorrilla de San Martín entregó un poema de mayor extensión al solicitado por las bases, quedó fuera de concurso. Si bien el ganador fue Aurelio Berro con Al monumento, el jurado ${ }^{269}$ decidió $^{2}$ que fuera el flamante poeta nacional quien leyera su composición frente a las cinco mil personas que se encontraban allí ese 19 de mayo de 1879.

Zorrilla de San Martín reconoció, en la correspondencia que mantuviera con Unamuno ciertas deficiencias o imperfecciones — «desaliñada y balbuciente» composición-, pero Arturo Sergio Visca afirmó, parafraseando a Crispo Acosta, que la obra y su recitación tomaron el cariz de un hecho histórico (Visca, 1979, p. 10). La razón de tan formidable conversión simbólica radicaba en el contexto histórico en que se desarrollaba el acontecimiento. Según nos explicaba el autor del prólogo, el pasado reciente del Uruguay, con 19 revoluciones en 45 años, hacía imposible la gesta del sentimiento nacional. Sin embargo,

\footnotetext{
${ }^{267}$ Versión ampliada y corregida de una conferencia dictada en noviembre de 1929.

${ }^{268}$ Ver el Capítulo 5.

${ }^{269}$ Compuesto por Alejandro Magariños Cervantes, Jaciento Albístur, Enrique de Arrascaeta, José Pedro Ramírez, Ángel Floro Costa y Manuel Herrero y Espinosa (Visca, 1979, p. 8).
} 
En lo que refiere al pasado más lejano (el pasado heroico de la gesta emancipadora), solo era conocido a medias y, por lo tanto, ofrecía un campo limitado de certidumbres en el que afianzar un sentimiento de nacionalidad. En este yermo, donde parecía destinado a naufragar cualquier intento de afianzar el sentimiento de nación y de alma colectiva, surge La leyenda patria. Y el poeta logra el milagro (Visca, 1979, p. 10).

Entonces, como ya hemos afirmado, la obra de Zorrilla de San Martín se convirtió en la piedra fundadora de la nación. La génesis del Uruguay, desde el punto de vista literario, ya reconocía a su primer astro rey en la figura del poeta nacional. La Colección... parecía saldar esta configuración, grabando a fuego la presencia del autor y su obra en el canon.

Zorrilla de San Martín fue uno de los integrantes del canon mayor, estudiado y reseñado por todas las historias de la literatura uruguaya, y editado en todas las colecciones que buscaban llevar adelante una historia literaria del país, algo solo compartido por Acevedo Díaz y Florencio Sánchez.

\section{El sistema de canonicidad}

La astronomía me permitió pensar una metáfora que describiera un sistema canónico acorde al caso estudiado. ¿Quién puso allí a esas estrellas?, ¿cuándo nacieron? ¿Por qué las constelaciones tienen esas formas? En el correr de nuestra vida, ¿se formarán nuevas constelaciones?, ¿desaparecerán algunas de ellas?, ¿cambiarán su forma? Todas estas preguntas se plantean al observador-lector interesado por los astros-autores.

Este sistema astronómico de canonicidad llevaría a entender la vida de una estrella, su supervivencia y muerte con la de los autores integrantes del canon. En nuestro universo, tendríamos que observar la génesis de los astros, hijos de las historias de la literatura nacional llevadas adelante por los primeros críticos literarios.

Las primeras estrellas conformaron unas tímidas y nóveles constelaciones que fueron adquiriendo mayor luminosidad con el paso del tiempo. Con la madurez del sistema de canonicidad, observamos la constelación central, más brillante y nítida, que fue la primera que nos encontramos en nuestro cielo literario. Sin embargo, si ponemos más atención, existen otras estrellas, más tímidas, con menor brillo, que buscarán ir acercándose a la constelación central.

Este firmamento, si bien es cambiante, tiene sus características generales y sus particularidades. Según la crítica literaria (Bloom, 2012, Sullá, 1998; Cella, 1998; Kermode, 1998; Mignolo, 1998; Harris, 1998; Even-Zohar, 1990; Pozuelo Yvancos, 1998; Rojas, 2000), una de las características del canon es su capacidad de cambio. Sin embargo, en Uruguay lo que 
hemos observado, desde el siglo XIX hasta pasada la mitad del XX, fue una cierta acumulación de nombres más que una variación de estos. Existen autores que, más allá de los cambios en las diferentes formas de hacer literatura y de los supuestos parricidios cometidos por las distintas generaciones literarias, se mantienen en el centro sin que bajen sus nombres de nuestro firmamento. Estos escritores ocupan la centralidad del canon; son nombres que están en el cielo literario como constelaciones que se mantendrán constantes en su magnitud aparente durante todo nuestro estudio.

Desplazándonos fuera del centro, entraríamos en el segundo círculo, o en la zona orbital, conformada por aquellos autores que giran alrededor de los astros. Estos sí podrían ser más cambiantes, podían ser abandonados y caer en desgarcia sin por ello dejar truncas las historias de la literatura nacional.

El cambio en la conformación canónica parece ser un movimiento de sumidero. O sea, una espiral que se arrima al centro, una caída hacia él. Se presentaría el autor en la periferia del canon (Pozuelo Yvancos, 1998; Even-Zohar, 1990; Mignolo, 1998), arrimándose a la centralidad, con velocidades variadas y a veces hasta suspendiéndose por momentos.

Respecto a la propia centralidad, no se observaron desprendimientos durante el período estudiado, una vez constituido por primera vez el canon - consideramos la obra de Roxlo como la impulsora, o como el Big Bang de las letras uruguayas, como ya hemos expuesto-, los nombres han permanecido. Eso se debe a la continua y sistemática repetición de autores y obras en todas las Historias de la literatura posteriores, lo que refuerza los nombres hegemónicos y centrales. Además, y en el caso del sistema educativo secundario y terciario, las nuevas generaciones literarias - sobre todo la crítica-, si bien acercaron otros nombres con propuestas innovadoras y vanguardistas, cuando practicaron la crítica, también se volvieron sobre los autores centrales.

Por lo tanto, no vemos en estos casos una puja, sino más bien una forma de acomodarse, abriéndose camino hacia el centro del canon. No hay agón (Bloom 2012); hay acercamiento. En el caso de Uruguay, la primera construcción canónica de Roxlo, a principios del siglo XX, estuvo íntimamente ligada a los centros de poder político y fue la que posibilitó la primera oficialidad dentro del ámbito privado. Recién hacia la mitad del siglo XX, el Estado se hizo cargo de la definitiva constitución laudatoria oficial de la lista de autores a ser leídos. La nueva masa de lectores, hijos de la extensión del sistema secundario, aseguró la correcta dirección de las lecturas, en un mundo que se observaba inestable y agredido por las nuevas lógicas internacionalistas e integracionistas, alejadas de las visiones conservadoras imperantes en el campo político uruguayo. 


\section{La constelación canónica central}

Como dijimos antes, lo que aquí llamamos la constelación canónica central es la que integran aquellos autores que, unánimemente, están en las distintas historias de la literatura nacional. Encontramos dentro de ella a doce nombres: Larrañaga, Magariños Cervantes, Acevedo Díaz, Zorrilla de San Martín, De Viana, Rodó, Herrera y Reissig, Agustini, Florencio Sánchez, María Eugenia Vaz Ferreira, Quiroga y Reyles. ${ }^{270}$ Absolutamente todos estos autores pasaron a integrar las listas de la Colección... La integración en términos de géneros literarios, de este selecto grupo de estrellas, es bastante variada. Hay cuatro poetas, tres ensayistas y cuentistas, dos novelistas y un dramaturgo. La conformación de esta lista pasó por varias etapas. Inicialmente, se imprimió a cada uno de ellos en sellos editoriales dedicados a los autores uruguayos como lo fueron Berreiro y Ramos, Dornaleche y Reyes, Vázquez Cores, Claudio García, entre otros. ${ }^{271}$ Luego fueron reseñados por los críticos de la literatura nacional, quienes, realizando un trabajo detallado sobre los libros editados, decidieron presentar a los integrantes de la lista mencionada como los dueños del carácter nacional en términos culturales. Finalmente, y luego de la sumativa de todos estos factores, el Estado decidió integrarlos a la nómina canónica oficial.

Si analizamos la pertenencia de los escritores a las diferentes generaciones literarias, podemos afirmar que los del Ateneo tuvieron tres participantes en el canon mayor, mientras que los del Novecientos sumaron ocho. Por otro lado, tanto los del Centenario como los de la Generación crítica no tuvieron ninguna aparición. ${ }^{272}$ Entendemos que, en parte, esta composición canónica se explica por el carácter conservador de la selección, sin integrar nuevas propuestas estéticas a la configuración nacional cultural que tenía el Estado.

Si bien los integrantes de la Generación crítica formaban parte de los prólogos de la Colección..., sus obras pasaron a integrar las listas oficiales recién hacia finales del siglo XX y a inicios del XXI, cuando sus novedades estéticas dejaron de ser tales, y cuando sus nombres ya se habían convertido en "clásicos" gracias al trabajo de otras colecciones de libros y de la crítica literaria. El Estado mantuvo su impronta de no jugarse en proponer nuevos nombres al canon, sino aceptar solo los consagrados.

\footnotetext{
${ }^{270}$ Ver el Anexo con lista de autores.

${ }^{271}$ Sobre estos sellos editores ver el dossier AAVV (2021). Una aproximación a la historia de la edición en Uruguay.

${ }^{272}$ Falta Larrañaga, pero a los efectos del análisis es un caso excepcional porque pertenece al período colonial.
} 


\section{Conclusiones parciales}

Como observamos en este capítulo, la conformación del canon oficial uruguayo no estuvo establecida gracias al agón entre autores (Bloom, 1994). Hemos propuesto que la configuración final del canon nacional fue dada por la única serie de libros editados por el Estado hasta la fecha.

Si bien se cree que existen desplazamientos canónicos durante las discusiones críticas, pensamos que en el caso uruguayo tales movimientos tienden a ser de sumidero y no de expulsión de escritores. Utilizando una metáfora astronómica, asumimos que la pequeñez del cielo literario uruguayo no dio lugar a la muerte estelar, sino más bien a la suma de cuerpos celestes en la oscuridad literaria nacional.

La Sirio de la literatura sería convenientemente Zorrilla de San Martín, quien fuera además génesis y centro del nuevo espacio. La constelación canónica central se iría conformando contemporáneamente a la aceptación del nuevo astro rey literario. Fue Roxlo quien propuso una primera carta astronómica para la posteridad crítica, que fue aceptada y actualizada de manera sistemática.

Por tanto, consideramos que con la Colección... estas configuraciones celestiales se terminaron de asentar en el panorama literario nacional. La serie de libros editados por el Estado laudó las listas hechas anteriormente, dando lugar a todos los autores consagrados y permitiendo el ingreso de otros nombres menores, pero con otras virtudes más allá de las estéticas.

Pivel se encargó, durante su ocupación ministerial y como jefe de la Comisión Editora, de llevar adelante la publicación casi entera de Zorrilla de San Martín, remarcando su centralidad en el canon y reafirmando su doble importancia, tanto literaria como historiográfica. ${ }^{273}$

El canon oficial uruguayo supone un caso especial por su limitado número de escritores, su pobreza en la cantidad de publicaciones y por la poca circulación de sus nombres dentro de la literatura universal. Tanto es así que el centro canónico nacional se halla en Zorrilla de San Martín, autor desconocido fuera de la región, y que respecto a los únicos nombres de importancia en el concierto mundial — como Onetti y Benedetti- poseen una presencia marginal. ${ }^{274}$

\footnotetext{
${ }^{273}$ Ver el Capítulo 5.

${ }^{274}$ Podríamos agregar también a Eduardo Galeano, sobre todo en los últimos años, cuando sus libros comenzaron a circular a nivel internacional y no solo en el ámbito latinoamericano, como venía sucediendo. En el caso de Onetti, su premio Cervantes en 1980 lo convierte en una referencia para las letras hispanoamericanas.
} 
Recordemos, para finalizar, que esta propuesta teórica no está pensada como un sistema general de canonicidad, sino que se aplica únicamente a nuestro período de estudio y para las obras y autores seleccionadas de manera oficial por el Estado uruguayo.

Si bien en este capítulo hemos trabajado con los integrantes de las listas canónicas, pretendemos en el próximo abordará aquellos que directamente fueron olvidados o censurados por las autoridades encargadas de la edición. Porque un canon es una decisión tanto de inclusión como de exclusión de obras y de autores. 


\title{
CAPÍTULO 7
}

\section{Censura y autocensura en la COleCCión...}

La censura y el libro moderno han tenido íntimas relaciones a través de toda su historia. Involucrando tres vértices (autor, manuscrito y censor), la censura habitualmente es vista como algo negativo. Se piensa que el censor es el encargado de sacar, borrar o hacer desaparecer aquello que no es factible que tenga visibilidad. La censura está emparentada con el poder. Para que tenga efecto, la posición del censor debe ser de autoridad.

En la Francia de los Borbones, por ejemplo, el censor establecía la calidad de los libros que le llegaban a sus manos antes de editarse. En las primeras páginas de los volúmenes aparecían las notas del o de los censores, y en general vertían juicios similares a los que encontramos en las contratapas de los libros. Allí se resaltaban algunas virtudes, hoy en día, hechas por críticos literarios (Darnton, 2014). Durante todo el siglo XVIII, el número de censores fue creciendo, lo que demostraba el aumento en la producción de libros (Darnton, 2014, p. 36).

Para saber si un libro era un producto de calidad, había que buscar entre sus páginas lo que decía el censor. Generalmente, durante la lectura de los manuscritos, se buscaban pasajes que no contuvieran nada que ofendiera a la Iglesia, la moral y el Estado (Darnton, 2014, p. 28). Pero era particularmente llamativo que muchas de las censuras estuvieran basadas en aspectos literarios más que ideológicos.

Según lo investigado por Darnton,

\begin{abstract}
Las inquietudes literarias de los censores se hacen particularmente evidentes en los informes negativos, donde uno podría esperar la mayor cantidad de vetos sobre todo tipo de herejías. Un censor condenó el «tono ligero y bromista» de un tratado sobre cosmología. Otro no presentó ninguna objeción teológica a una biografía del profeta Mahoma pero declaró el libro superficial y falto de investigación. [Otro censor] rechazó un tratado legal alegando que utilizaba terminología inexacta, documentos mal fechados, malentendía principios básicos y estaba lleno de faltas de ortografía (Darnton, 2014, p. 29).
\end{abstract}

Si bien claramente algunas censuras eran puramente ideológicas, no deberíamos descuidar que había aspectos literarios que también eran tenidos en cuenta. Corregían fraseos, ortografía, sintaxis, y hasta la aritmética cuando era necesario (Darnton, 2014, p. 43). 
Todo censor, cuando le llegaban a sus manos escritos, podía tomar tres posturas: otorgarle al libro el privilegio de ser editado con la aprobación y nombre del censor, recomendar un permiso con aval oficial y que pareciera que el libro era impreso en el extranjero, o directamente negar la autorización para su impresión, por lo cual el ejemplar o no era publicado o lo era solo ilegalmente (Darnton, 2014, pp. 31-32).

Por lo tanto, la censura fue un fenómeno más complejo que la mera prohibición; operaba como una lectura previa, implicando mantener el original, realizarle cambios, o eliminar lo censado. Muchas veces los censores se reunían con el autor, y debatían sobre los manuscritos, intentando mejorar y pulir lo textos, pues «en lugar de reprimir la literatura hacían que ésta ocurriera» (Darnton, 2014, p. 50). La censura incidía además en el propio proceso de escritura, porque el autor solía tener en cuenta la existencia del censor, condicionando su texto incluso para evitar la censura.

A veces olvidamos que no solo es necesario tener en cuenta lo que se publica, sino también lo no publicado. En el caso de la Colección..., podemos estudiar su catálogo, observando las distintas obras publicadas para comprender la política editorial llevada adelante, pero también podemos realizar un análisis de aquello que su editor más importante decidió dejar en el olvido. Pivel tuvo el poder y la decisión para imprimirle al proyecto estatal un carácter particular que se ha mantenido, en algunos aspectos, hasta el día de hoy. En la Colección..., la figura del censor recayó generalmente en la Comisión editora, que funcionaba como una primera instancia de la censura. Seleccionadas las obras, la censura pasaba a manos del editor en jefe. Como veremos, desde 1959 hasta 1982, esa persona fue Pivel.

Este capítulo se centra en cuatro casos de censura contenidos en la historia de la Colección...: el de un prologuista que no aceptó los planteos de Pivel, para modificar el manuscrito enviado para su corrección; lo sucedido con la obra de Eduardo Acevedo Vásquez, «olvidada» por parte de la Biblioteca Artigas; el caso de dos historiadores que fueron dejados de lado por decisión directa de su editor, y la autocensura de un importante crítico literario, que se adaptó a las exigencias de la Comisión de la Colección..., modificando su texto.

\section{Delmira y el prólogo vacío}

Múltiples testimonios dan cuenta de que Pivel era un eficiente empleado de la administración. Su eficacia y la constante autoexigencia en cumplir con los plazos en toda tarea que desarrollara también se percibía en la exigencia para con sus colaboradores. Así, por ejemplo, cuando invitó 
a Guido Castillo a hacerse cargo del prólogo de la selección de obras teatrales de Florencio Sánchez (que se editó en 1967, en dos tomos, con el título Teatro), desde octubre de 1964, exhortó al prologuista a que se hiciera cargo de la selección y el estudio preliminar, pero ante la falta de respuesta, el ministro fue cortante: «Debo interpretar su silencio como una manifestación negativa. En consecuencia, puede Ud. considerarse desligado de todo compromiso con la Biblioteca Artigas, y yo en libertad para encomendar el prólogo a otro colaborador» (Carta al Señor don Guido Castillo, 23 de octubre de 1965, AGNU, Colección Pivel Devoto, caja 258, carp. 911). Finalmente, fue Walter Rela el encargado de realizar ese estudio preliminar.

Esta celeridad, pretendida por Pivel para los trabajos llevados a cabo bajo su dirección, no era el único punto que había que cumplir para ser editado en la Colección...: además de rapidez, tenía que existir cierta coincidencia de criterios... En otras palabras, era necesario pasar por la censura piveliana.

Un ejemplo interesante sobre cómo aquello que se alejaba de los lineamientos de Pivel no era tenido en cuenta, puede observarse en el rechazo de uno de los prólogos: el estudio previo que se le pidió a Roberto Bula Píriz, sobre la Antología de poemas de Delmira Agustini, que saldría en el volumen 69 de la Colección... Bula fue llamado por Pivel ya que era, además de poeta, crítico literario con varios estudios de autores uruguayos en su haber: había escrito sobre Julio Herrera y Reissig, María Eugenia Vaz Ferreira y sobre la propia Agustini. Durante el período de 1969 a 1972, fue director de la página literaria del periódico La Mañana, donde se reeditó, en 1989, uno de los estudios sobre Agustini al que haremos referencia.

Sabemos que Pivel indicó cambios al trabajo entregado por Bula, pero no sabemos cuáles fueron. ${ }^{275}$ Por tanto, tendremos que entrar en el terreno de la hipótesis, observando los artículos sobre Agustini editados por el prologuista, y que muy probablemente integraron, a grandes rasgos, lo presentado para la Colección...

Cabe aclarar que la vida personal de Delmira Agustini sigue suscitando mayor interés para el público masivo que su rica obra. En consecuencia, se escribieron varias biografías que, en general, hicieron hincapié en su trágica y escandalosa muerte. El interés que genera hasta el día de hoy su triste final trae a la mente la última obra, editada en 2013 por Diego Fisher, texto que volvió a colocar a Agustini en el centro de un escándalo mediático: en su libro Serás mía o de nadie. La verdadera muerte de Delmira Agustini, el autor pretende colocar el femicidio al que fue sometida su biografiada, como un pacto mortal de amor entre ella y su ex marido, algo

\footnotetext{
${ }^{275}$ En una entrevista inédita realizada el 10 de julio de 2013 al actual director de la Colección..., Wilfredo Penco manifestó que «Yo conocí bastante a Bula Píriz, y alguna vez él me contó esto» (Gutiérrez, 2013a).
} 
muy similar a lo sugerido por Bula. Dejando de lado lo doblemente oportunista de la obra, en momentos de lucha contra los femicidios, y del centenario de la muerte de la poetisa, la muerte de Agustini sigue dando qué hablar. Si aun hoy lo publicado por Fisher (2013), a principios del siglo XXI, genera conmoción en la población uruguaya, hacia la mitad del siglo XX, la edición de un prólogo con esa perspectiva ideológica, en el canon oficial de la colección de Pivel, seguramente se habría convertido en un escándalo en el cual el director no hubiera querido participar.

El prólogo que hizo Bula parece basarse en la biografía de la autora mucho más que en su obra literaria. Prueba de ello, y de que a Pivel no le gustó el estudio que redactó el crítico literario, es una de las cartas de Pivel: «Lamento que Ud. no haya tomado en cuenta las sugestiones que le hice en mi despacho del Ministerio, sobre las inconveniencias de ciertos pasajes cuya modificación me permití la libertad de proponerle». ${ }^{276} \mathrm{Y}$ como quedó expuesto, esos cambios no se realizaron, por lo que terminó diciendo que «La publicación realizada por Ud. releva al Ministerio de todo compromiso sobre el prólogo que oportunamente le fue encomendado». ${ }^{277}$

Como dijimos, ante la ausencia de un borrador del prólogo, en el archivo de materiales sobre la Colección..., podemos apelar hipotéticamente al texto publicado inicialmente por Bula en 1964, y posteriormente reeditado en una separata de La Mañana en 1989. Este texto siguió una estructura extendida en la época: contexto, biografía, características de la obra y selección de poemas.

Si comparamos los dos textos publicados por Bula con una diferencia de 25 años, podemos observar que son muy parecidos, salvo porque al texto posterior se le corrigieron algunas expresiones y se redujo el análisis biográfico, enfocándose mucho más en la obra de la poetisa. Probablemente, este fue uno de los problemas encontrados por Pivel: si Agustini era un clásico de la literatura nacional, debía ser por su valor artístico y no por las circunstancias de su muerte.

Observemos el probable texto entregado por Bula, que inició su estudio partiendo de la biografía, y que se apoyó especialmente en su muerte (ya que el crítico literario apeló a interpretar toda la vida de Agustini a partir del crimen):

El día lunes de este año se cumplieron cincuenta de aquel otro lunes 6 de julio de 1914, en el que Delmira Agustini fue muerta por dos balazos en la cabeza por su ex-esposo, Enrique Job Reyes, que se suicidó enseguida, en la pieza a donde ella iba a visitarlo. Eran jóvenes, y el amor había arraigado en sus vidas

\footnotetext{
${ }^{276}$ AGNU, Archivo Pivel Devoto, Carta al Señor don Roberto Bula Píriz, 11 de enero de 1965, caja 258, carp. 911. ${ }^{277}$ Ídem.
} 
creciendo e invadiéndolas hasta volverlas una. Su muerte, que las crónicas de los diarios llamaban crimen pasional, configuró un doble suicidio por amor sin romanticismo ni misterio. En el sacrificio de sus vidas hallaron un ideal para surgir heroicamente a la libertad (Bula Píriz, 1964, p. 3).

La primera parte de lo publicado en 1964 se cierra con una pregunta que deja entrever su perspectiva patriarcalista: «Siguió viéndose, escribiéndose, soñándose con él hasta el 6 de julio de 1914. Hacía un mes que se había concluido el juicio de divorcio. Como un relámpago, la vida derramó su ánfora. ¿Qué pasó?» (Bula Píriz, 1964, p. 4).

El texto intentaba explicar dicha cuestión convirtiendo la violencia de género en amor romántico. Pero antes de emprender la biografía, el autor necesitó hacer una larga disertación sobre el valor de la crítica y los críticos. Bula, por lo que él igual declara, era una figura polémica para su época

...la vida no es comodidad, sino lucha, irresignación, amor a la verdad, es decir, amor a la belleza. Pero la belleza es terrible. Deseo infundirme por ella, sin embargo, y ser de mi opinión en vez de seguir la corriente general, pues cargo bastantes defectos propios para adoptar otros ajenos. Por lo demás, mi manera de valorar seres y cosas hace que desprecie la mayoría de los que son ordinariamente estimados como importantes, y estime otros a los que se tiene por costumbre no tomar en cuenta. No me alegraré si mi interpretación de Delmira Agustini es mal mirada por algunos ni me molestaré si concuerda con la opinión de otros (Bula Píriz,1964, p. 5).

Pero esa opinión de «otros» era fundamental para la Colección... Al constituirse como una serie de libros canónicos nacionales, los prólogos debían ser cuidadosamente seleccionados y seguir una misma tónica «profesionalizante» de la crítica literaria y del pensamiento nacionales. Pivel no se podía permitir un escándalo dentro del campo intelectual, como el centrado en sobrevalorar el peso de la biografía o peor aun, transformar la violencia de un crimen en un motivo romántico de amor desgraciado, como clave interpretativa de la obra.

En el cierre de su estudio, que probablemente se acercó al contenido de su prólogo, Bula se animó a realizar una reflexión sobre el final de las vidas de Agustini y su ex esposo, incorporando un juicio inquietante:

A pesar de las visitas de ella a él, que se pasaba días y semanas encerrado en su pieza para que sus ojos no contemplaran más que los muros que como en un milagro de espejos le devolvían su recuerdo enamorado; a pesar de los paseos, siempre fugaces y furtivos, por los alrededores de la ciudad, sentían que sus almas estaban prisioneras, que eran dos pájaros ciegos dándose contra los barrotes en su jaula. Y encontraron la sola brecha por donde derramar su amor con la limpidez que necesitaban. Fue el 6 de julio de 1914. ¡Cuánta (sic) 
desesperación habrá habido en esos dos jóvenes que eran un solo ¡hurra! a la vida, para cambiarla por la muerte. Pero en ese momento Ella fue su luz, La Luz. Necesitaban la libertad, que vale muy mucho más que la vida (Bula Píriz, 1964, p.13).

Bula se acercaba entonces a la comprensión del crimen desde un punto de vista romántico y conservador, justificando incluso el delito. Sus palabras deben haber desatado la polémica. Bula manutuvo probablemente su «manera de valorar seres y cosas»y, por ser dueño de esa personalidad que no se molestaba por concordar con la opinión de otros, no cambió el texto como quiso Pivel. El resultado estuvo a la vista: su prólogo fue censurado y posteriormente desechado.

En efecto, Pivel entendió que, si no se modificaba ese estudio preliminar, otra persona debía encargarse de dicha tarea. Y lo mejor era encargárselo a alguien de confianza del editor. Así, Esther de Cáceres fue quien asumió la tarea de redactar el prólogo y de compilar la Antología (1965) del tomo 69. No es ingenua la elección de dicha autora para emprender un estudio previo que no estaba dando con los deseos de Pivel.

Debemos recordar que de Cáceres integraba el círculo más estrecho de la red intelectual piveliana ya que era muy allegada a la esposa del historiador, Alcira Ranieri. Poetisa, docente y crítica literaria, colaboró con cinco prólogos de la Colección... ${ }^{278}$ Además, se trataba de una ferviente católica, así como también lo era la esposa de Pivel, y este punto era extremadamente importante tratándose de realizar un estudio previo a la obra y la figura de Agustini.

De hecho, lo escrito por de Cáceres, para la antología de Agustini, revelaba claramente su convergencia con la visión de Pivel respecto de la colección de libros del Estado. La autora abrió su trabajo con una reflexión autobiográfica respecto de su primer contacto con la obra de Agustini:

Por diversas vías, en la primera etapa de mi adolescencia, tuve yo noticia de Delmira Agustini, y desde entonces siempre, por las dos diversas vías, ella me ha llegado, hasta quedarse al fin sus imágenes y sus cantos en mi alma, ya libres de mundo y tiempo, en las más secretas zonas de mi ser asombrado.

Recuerdo aquellas dos vías. Una por voz opaca y multitudinaria de gentes poseídas por nerviosa curiosidad. Era en una calle de Montevideo marginada de plátanos; una calle a la que se asomaba mi infancia angustiada o feliz, entre apacibles azulejos, misterioso aljibe, jazmines del cielo... Era un cortejo fúnebre que llevaba a dormir entre cipreses a dos criaturas jóvenes, unidas por el signo de la Muerte. A la vez todos los diarios deban largas crónicas, sensacionales fotografías, entre las que aparecían resplandecientes poemas de

\footnotetext{
${ }^{278}$ Llevó adelante los prólogos a La isla de los cánticos de María Eugenia Vaz Ferreira (1956), Teseo. Los problemas del Arte de Eduardo Dieste (1964), La recuperación del objeto de Joaquín Torres García (1965), Raza ciega y otros cuentos de Francisco Espínola (1967), y la Antología de Delmira Agustini (1965).
} 


\begin{abstract}
Delmira Agustini como una réplica de voz sobrehumana al sórdido lenguaje convencional.

La noticia caía así sobre mi alma como una sorpresa chocante y áspera. Y ni la luz plateada de los azulejos, ni la verde sombra dulce de los plátanos podrían ya amortiguar este paso de la infancia transida amarga y oscuramente por un extraño luto y un plañir informe; por aquel ruido que violaba los silencios sagrados de la Muerte.

Luego la otra, la noble vía (De Cáceres, 1965, p. 7).
\end{abstract}

La muerte de la poetisa se difuminaba en el lenguaje poético de la prologuista, que acompañaba el discurso poético de la propia Agustini, insistiendo en hacer converger su trabajo literario con su experiencia biográfica. Pero luego de las referencias necesarias a su conocido final, se hizo un cambio radical al hablar de la otra vía - la poética - por la que transcurrió la personalidad de Agustini; sin duda, fue esa la que pretendió Pivel, y la que de Cáceres, como fiel colaboradora, se dispuso a transitar.

\title{
Una enemistad post mortem
}

Pivel fue un editor que pretendió el equilibrio en su selección. Blancos y colorados, como representantes de los dos partidos mayoritarios e históricos del Uruguay, tenían a sus historiadores y sus formas de ver la historia. El equilibrio que buscaba superar las diferencias en el relato nacional fue mantenido rigurosamente durante toda su estancia al frente de la Colección..., salvo por un nombre: el de Eduardo Acevedo Vásquez.

Acevedo fue abogado, economista, periodista, historiador y un activo hombre de gobierno colorado, sobre todo durante el batllismo. Tuvo cargos en muchos y variados ministerios; fue catedrático en la Facultad de Derecho, y llegó a ser Rector de la Universidad (1904-1906), director del Banco República (1914-1924), y director de Enseñanza Primaria (1925-1929), además de integrar diversas instituciones sociales como el Ateneo de Montevideo, la Sociedad de Amigos de la Educación Popular (fundada junto a su cuñado, José Pedro Varela, entre otros), e históricas como el Instituto Histórico y Geográfico del Uruguay.

$\mathrm{Su}$ actividad historiográfica marcó hondamente a sus contemporáneos y a posteriores estudiosos de la historia nacional. El límite temporal de su obra fue el Golpe de estado de Gabriel Terra en marzo de 1933, momento en que se ponía fin al período batllista. ${ }^{279}$ Sus libros fueron determinantes, sobre todo dos: José Artigas, Jefe de los Orientales y Protector de los

\footnotetext{
${ }^{279}$ En términos historiográficos el batllismo finalizó en 1929 con la muerte del propio José Batlle y Ordóñez. Sin embargo, luego del golpe de Estado de Gabriel Terra, su puso fin a la constitución redactada en 1918, lo que daba por terminado el período de conquistas sociales y económicas iniciado en 1903 por Battle.
} 
Pueblos Libres. Su obra cívica. Alegato Histórico editado en 1909 (libro fuertemente proartiguista), y los Anales Históricos del Uruguay, que salieron en seis tomos entre 1933 y 1936.

Por lo tanto, si trazamos un paralelismo entre Pivel y Acevedo, atendiendo a la historiografía nacional, podríamos afirmar que, si bien Pivel dominó el campo durante la segunda mitad del siglo XX, sucedió lo mismo con Acevedo en la primera mitad. Es interesante destacar que Pivel fue premiado por Acevedo en 1941, al ganar el concurso «Pablo Blanco Acevedo», por su libro Historia de los partidos políticos..., lo que de alguna manera los emparenta historiográficamente, a través del reconocimiento de un viejo historiador, dándole paso al joven Pivel.

Sabemos que el relato historiográfico de Acevedo fue claramente colorado y contrario a la gran mayoría de las posteriores posturas de Pivel pues, de alguna manera, el relato piveliano se construyó en contraposición a muchas de las explicaciones reseñadas en los Anales... Por ejemplo, en los primeros pasos del nuevo país, Acevedo fustigaba duramente a Manuel Oribe (el progenitor del Partido Blanco), por su alianza con Juan Manuel de Rosas, y en cambio enaltecía a la figura de Rivera (el fundador Colorado); en cambio, si bien Pivel no castigaba a Rivera, hacía emerger la figura de Oribe como la de un defensor de la nacionalidad oriental.

Habitualmente, la explicación que se da ante la no publicación del texto de Acevedo en la serie de libros estudiados, es que su postura netamente coloradista influyó para que el editor de la Colección ... lo dejara de lado. Sin embargo, con esta argumentación no logramos explicar cómo, si la Biblioteca Artigas pretendía mostrar las obras canónicas de la historiografía nacional, no hizo lugar a una figura de la talla de Acevedo. La conciliación ideológica piveliana, en aras de un relato unificado de los orígenes y del desarrollo de la nacionalidad uruguaya, se contradice en principio con este olvido. Para desentrañar este problema, es necesario retrotraernos varios años antes de la salida del primer tomo de toda la colección.

En junio de 1944 se creó por ley el Archivo Artigas, con la finalidad de compilar y editar todos los documentos relacionados con la vida pública y privada del caudillo oriental. El primer tomo salió en 1950. La comisión editora estuvo integrada por Felipe Ferreiro, Carlos Carbajal, José M. Fernández Saldaña, Ariosto Fernández, Dionisio Trillo Pays, Juan Carlos Gómez Haedo y Juan Pivel Devoto. Sin embargo, no encontramos en la lista la mención de uno de los miembros fundadores, Eduardo Acevedo. ¿Por qué?

El 20 de junio de 1945, Acevedo, hasta entonces director de la Comisión del Archivo Artigas, presentó su renuncia ante el Ministro de Instrucción Pública y Previsión Social, Adolfo Folle Juanicó. Acevedo decidió explicar el por qué de la decisión, dando lugar a una larga exposición: 
Desde las primeras reuniones de nuestra Comisión, se elaboró un plan de organización y funcionamiento de las tres secciones en que se dividiría el trabajo: la sección de Coordinación, a cargo del Profesor Ariosto Fernández, actualmente en el Brasil, donde realiza una grande y fecunda labor; la sección de Coordinación, a cargo del director del Museo Histórico Nacional, Profesor Juan Pivel Devoto; y la sección de Publicación, Fichado e Índices a cargo del director de la Biblioteca Nacional, Profesor Juan Silva Vila. ${ }^{280}$

Acevedo estuvo al frente de este proyecto, ya que era merecedor de la confianza de los colorados y, además, una figura fundamental a nivel historiográfico para el afianzamiento de la nacionalidad uruguaya. Para el partido de gobierno, Acevedo representaba la historia contada desde el coloradismo. Ejerciendo el poder cultural que la larga estancia en el poder político le otorgaba, se lo nombró director de la comisión para la edición de los documentos de Artigas.

Por entonces el joven Pivel, ya respetado en los escuetos círculos historiográficos del Uruguay, y en una posición de relativa importancia, era director del Museo Histórico desde 1940, gracias al apoyo del caudillo blanco Luis Alberto de Herrera (de quien era íntimo amigo), y de una larga lista de historiadores entre los que se encontraba Acevedo. Además, ya había publicado dos de sus libros más importantes, la Historia de los partidos políticos en el Uruguay (1942), y la Historia de la República Oriental del Uruguay (1945).

Pivel emergía como la otra voz, que hacía frente a la posición hegemónica de Acevedo que, con el tiempo, comenzaba a desmoronarse. Frente a ese legado previo Pivel tenía dos ventajas: una importante diferencia generacional (Acevedo murió en 1948, sin ver el primer tomo del Archivo editado), y el avance electoral de su Partido Nacional, que ascendió al poder en 1959.

Volvamos a la renuncia de Acevedo:

He atribuido escasa importancia a los planes casi siempre provisorios, del primer momento, convencido de que es solo después de formalizados los trabajos, cuando llega la oportunidad de plantearlos y resolverlos con verdadero conocimiento de causa.

Esa oportunidad acaba de llegar, con motivo de una disidencia fundamental entre el Jefe de la Sección de Coordinación, el Profesor Pivel Devoto, y el jefe de la sección Publicaciones, Fichado e Índices, profesor Silva Vila.

En concepto del señor Pivel Devoto, el Archivo Artigas debe ser organizado sobre la base de series documentales y no por orden cronológico de los documentos.

En concepto del señor Silva Vila, el Archivo Artigas debe ser organizado por oden (sic) cronológico, juzgando que las series documentales tienen que hacerse a base de interpretaciones, o sea de crítica histórica, y que esas

\footnotetext{
${ }^{280} \mathrm{AGNU}$, Archivo Pivel Devoto, caja 114, carp. 362.
} 
interpretaciones no corresponden a nuestra Comisión Oficial, sino a los historiadores que se propagan estudiar a Artigas.

Advierto que la opinión mundial está dividida. ${ }^{281}$

El problema que se señala tiene que ver con el manejo documental, pero de fondo hay otra cuestión: el inicio de una lucha, desarrollada posteriormente, por la hegemonía del campo historiográfico, con Pivel como antagonista respecto de Acevedo.

Debemos recordar que toda esta documentación se encuentra en el archivo personal de Pivel. ${ }^{282} \mathrm{El}$ documento antes citado concluye la serie de problemas que surgieron en las reuniones entre Pivel, Acevedo y Silva. Por ejemplo, Pivel fue muy crítico con respecto al trabajo llevado adelante por Edmundo Narancio (historiador cercano a Acevedo) en Buenos Aires. Consideraba que no era necesario realizar investigaciones en Argentina, hasta que no se hiciera el relevo completo de los contenidos de los archivos uruguayos. Además, Pivel encontró algunos errores en las series documentales copiadas por Silva, y se lo hizo notar en las reuniones del Archivo.

Un ejemplo de estas batallas intestinas se encuentra en una carta a Acevedo del 22 de junio de 1945, en donde Pivel le comunica que

... ha llegado a mi conocimiento la versión según la cual se me atribuye el
propósito de incluir, en determinada serie documental del Archivo Artigas, un
documento en el que se compara la época de Artigas con la de Rosas. Yo no
tengo noticia de la existencia de esta pieza. Por lo tanto, solicito del Señor
Presidente se me informe. $1 .^{\circ} \mathrm{Si}$ es exacta aquella versión. $2 .^{\circ}$ Qué
investigador localizó ese documento y en qué Archivo nacional o extranjero
se halle el original. $3 .^{\circ}$ Cuándo fue incorporado al Archivo Artigas, datos estos
que solicito me sean facilitados previo informe del departamento
respectivo.

Además, agregaba que como no había podido ir a la reunión, pedía una copia del fragmento correspondiente. Parece desprenderse, de esta serie documental, que la actitud de Pivel para con el director de la comisión y el resto de sus compañeros era muy rígida. Aparentemente, para él la mejor manera de hacerse espacio en el campo historiográfico era mostrarse inflexible y profesional. Pivel no solo criticaba abiertamente a la comisión, sino que además se mostraba atento y sin miedo de dar su punto de vista y defenderlo ante quien fuera, sin importar su posición jerárquica.

Veamos ahora sí el motivo de la renuncia de Acevedo:

\footnotetext{
${ }^{281}$ Ídem.

${ }^{282}$ La carpeta que lleva por título «Archivo Artigas» cuenta con 300 folios (AGNU, Archivo Pivel Devoto).

${ }^{283}$ AGNU, Archivo Pivel Devoto, caja 114, carp. 362.
} 
Puesta a discusión esta disidencia, votó la mayoría de nuestra Comisión la fórmula del Profesor Pivel Devoto, con modificación, según el cual, dentro de las series documentales se mantendría el orden cronológico.

Yo me pronuncié a favor del orden cronológico, propuesto por el profesor Silva Vila. Y debo establecer los fundamentos de mi voto porque no lo hice en la sesión del viernes último, por razones personales.

Tengo un alto concepto del profesor Pivel Devoto, como hombre de estudio, revelado en numerosas e importantes publicaciones históricas; como hombre de extraordinaria laboriosidad y como organizador extraordinario también de los Museos Tivera (sic), Lavalleja y Pablo Blanco Acevedo.

Pero yo no estoy de acuerdo con su criterio histórico. Y tal falta de acuerdo es de capital importancia para mí tratándose de Artigas. ${ }^{284}$

En esta cita de un documento conservado en el archivo personal de Pivel, el subrayado, que pertenece al original, probablemente fue hecho por el propio Pivel (en general usaba lápiz, como en este caso, para escribir notas y subrayar textos), como una manera de señalar que Acevedo aseguraba el por qué de su alejamiento y, por tanto, su posterior mentira en la prensa. Los problemas de Acevedo con Pivel tocaron fondo: en la votación, Pivel había podido vencerlo, y Acevedo no pudo tolerar esa derrota. La información sobre el alejamiento de Acevedo de la Comisión del Archivo Artigas llegó a la opinión pública, y

... se dijo en la prensa que esa renuncia era motivada por discrepancias técnicas e ideológicas con un miembro de la Comisión. Que ese mismo día llamó la atención sobre el hecho al Sr. Presidente, y como éste en la copia de la renuncia que le dio a conocer, se refería a discrepancias de criterios históricos y no se decidiera a enviar ninguna satisfacción — como lo ha hecho en otro caso sin necesidad de reunir a la Comisión-, se creyó plenamente habilitado para publicar en la prensa parte de la exposición que había leído, con lo cual desautorizaba las versiones antojadizas. ${ }^{285}$

Pivel tomó la copia de la renuncia de Acevedo y la publicó en la prensa para demostrar que no hubo ninguna discrepancia ideológica, sino que fue más bien un tema técnico. Claramente, Pivel creyó desatinado el gesto de Acevedo y viceversa, por lo que la situación quedó muy tensa entre ellos.

Como recordamos, tres años más tarde, en 1948, Acevedo murió, y Pivel siguió su lento pero seguro ascenso en las distintas administraciones del Estado, donde formó parte, desde 1950, de la comisión editora de la Colección de Clásicos.

\footnotetext{
${ }^{284}$ Ídem.

${ }^{285}$ Ídem.
} 
Si bien generalmente se resalta que la visión coloradista, que tuvo Acevedo en su obra historiográfica, fue el motivo por el cual quedó fuera de la Colección..., este incidente tuvo una importancia significativa, incluso por el cuidado con que Pivel conservó los detalles sobre él (lo cual no es algo ingenuo, en su caso).

Además, si cuando se ideó el plan de edición, por parte de la Comisión Editora de la Colección..., el nombre de Acevedo aparecía en la lista de autores seleccionados, sin embargo, fue uno de los pocos casos (junto con Juan Carlos Gómez) que luego quedaron afuera. ${ }^{286}$

La desaparición de las obras de Acevedo en la Biblioteca atestigua algo más que un olvido: deja entrever la existencia de una prohibición, marcada por la enemistad y la lucha por la hegemonía de los discursos historiográficos.

\section{Debates con la historia}

Un relato que fuera muy poco funcional a la construcción de la nacionalidad no podría tener lugar en una antología dedicada a generar un canon historiográfico y literario. Por ende, analizaremos brevemente los casos de Juan Carlos Gómez y Francisco Berra, ya que nos parecen paradigmáticos como visiones historiográficas contrarias al artiguismo de Pivel.

En múltiples oportunidades, Pivel demostró su desacuerdo frente a varios adscriptos a la llamada «leyenda negra artiguista», golpeando directamente, con argumentos propios, las obras y posturas de dichos historiadores, o criticando de manera indirecta, a través de citas de autores que lo hicieran por él. Por ejemplo, en ocasión del prólogo a la Historia de la dominación española, recordaba Pivel que Bauzá había fustigado a Gómez, acusándolo de desconocer la historia nacional y de ser incapaz de ubicarse en el escenario político uruguayo, debido a su apoyo al Partido Conservador, ${ }^{287}$ al que tildó de «revoltoso y anárquico» (Pivel, 1965, p. 234). También agregó, luego de una larga cita, ${ }^{288}$ que Bauzá

...destruye la tesis peregrina del Dr. Gómez de que nuestra independencia fuera el resultado de una concesión graciable hecha por el gobernador Manuel Dorrego y el Emperador Pedro I, y demuestra cómo la segunda ley dictada

\footnotetext{
${ }^{286}$ AGNU, Ministerio de Instrucción Pública y Seguridad Social, caja 589, carp. 3138.

${ }^{287}$ El Partido Conservador fue fundado luego de la Guerra Grande (1839-1851), y pretendió «conservar» los ideales del llamado «Gobierno de la Defensa». Se trató de un grupo escindido del coloradismo.

${ }^{288}$ Pivel cita a Bauzá cuando éste dice, en una serie de artículos titulados La Independencia del Uruguay, publicados en el diario La Nación de Montevideo entre el 30 de septiembre y el 4 de octubre de 1879, que: «La República del Uruguay es independiente por el esfuerzo de sus hijos y contra la voluntad de sus dominadores intrusos. San José y Las Piedras demostraron que no queríamos ser españoles; Guayabos y Cagancha que no queríamos ser argentinos. Haedo y Sarandí que no queríamos ser brasileños. Las combinaciones diplomáticas y aun las vistas particulares de propios y extraños, se estrellaron durante todo el largo período de la lucha por la independencia, contra estas determinaciones airadas de la voluntad nacional, triunfando por último el pueblo, que era quien había preparado, perseguido y alcanzado la conquista de su emancipación política» (Pivel, 1965, p. 235). Claramente, es un golpe dirigido a la tesis de Gómez.
} 
[...] [el] 25 de agosto de 1825, que declaró la incorporación del país a las Provincias Unidas, no podía servir de fundamento a la pretensión de Juan Carlos Gómez para arremeter cuarenta años después contra la realidad configurada por el país independiente y constituido (Pivel, 1965, p. 235).

Recordemos entonces que - de forma directa cuando era él quien afirmaba, y de manera indirecta cuando utilizaba citas de otros historiadores-, Pivel aprovechó cada ocasión que tuvo para golpear las tesis contrarias a la historia oficialista y nacional que se tejió desde los prólogos de la Colección ... y desde su propio proyecto intelectual.

Unas páginas más adelante en el estudio previo analizado, repitió esa crítica al pasar, cuando retomó el mismo tema, pero con nuevas referencias y golpes contra la postura anexionista de Gómez. El autor fue visto por Pivel como un enemigo, tal como había sido enemigo de Bauzá. Al respecto, podemos acotar lo que rememoraba un ex alumno de Pivel, el historiador José Rilla:

\begin{abstract}
No puedo sino recordar aquí a Pivel cuando nos tomaba examen de Historia Nacional en el Instituto de Profesores Artigas [...]. Era un gran conocedor del pasado -así dicho- y un fervoroso nacionalista [...]. Se encendía entonces, durante aquellos exámenes, en una pasión nacional para muchos de nosotros desmedida o anacrónica; preguntaba y se contestaba a sí mismo, parecía tener enfrente a Juan Carlos Gómez o al mismo Berro, escéptico el primero con la nación y el segundo con los partidos políticos. El alumno de ocasión era vicario para un debate de Pivel con la historia (Rilla, 2008, p. 195).
\end{abstract}

En los diferentes prólogos y artículos que se lo permitieron, Pivel mantuvo ese mismo debate interminable, al que fueron sometidos los distintos críticos del artiguismo y de la génesis autónoma de la nación uruguaya. No solo era vencer y sepultar, con argumentos válidos, la visión anti-artiguista y anti-nacionalista a nivel historiográfico, sino también desprestigiar y hacer insostenible el rescate de esos autores; crear unanimidad; ya no solo hegemonizar la discusión, sino algo más: eliminarla.

Como adelantamos, la censura también se practicó sobre la obra de Francisco Berra, que había publicado inicialmente un libro de historia nacional llamado Bosquejo histórico, en 1866. En 1881, se llevó a cabo la tercera edición de la obra, que le valió una fuerte polémica con Carlos María Ramírez, durante 1882, en la prensa de Buenos Aires. ${ }^{289}$ En 1883, durante el gobierno autoritario del Gral. Máximo Santos, el Ministerio de Gobierno proscribió el texto de Berra por considerar que la enseñanza que impartía el Estado debía estar orientada a fortalecer

\footnotetext{
${ }^{289} \mathrm{La}$ imposibilidad de hacerlo, en los diarios montevideanos, tenía que ver con el gobierno autoritario de Francisco Vidal, que había suprimido en 1881 la libertad de imprenta.
} 
el sentimiento nacional en los jóvenes, y que las ideas anti-nacionales no podían ser permitidas; la independencia y la nación no debían ser atacadas. ${ }^{290}$

En su postura historiográfica, Berra afirmaba que la independencia del Uruguay había sido impuesta a los orientales por parte de las dos naciones en pugna — Brasil y Argentinadurante la guerra de 1825-1828, y que había tenido su desenlace en la Convención Preliminar de Paz, de 1828. Además, consideraba a Artigas una personalidad negativa para la región, dueña de un importante mal genio, egoísta, orgullosa y plagada de errores militares y políticos. También lo hizo culpable de la invasión lusitana en 1816, que provocó el largo período de dominación lusobrasileña (1816-1828).

En la tercera edición del Bosquejo histórico... (1881), que figura en la biblioteca personal de Pivel, solo existe una anotación en todo el libro. Más que una referencia, ésta parece una advertencia que preside su lectura. Con respecto al tratamiento de la figura de Artigas, se puede leer que, «Al referirse al Bosquejo... Bauzá dijo en el prólogo de la historia que Berra había hecho bien en 'no emprender el retrato, pues con el bosquejo sobra para muestra pág. LVI'». ${ }^{291}$ Así, con una simple frase de Bauzá, Pivel desterraba la obra entera de Berra. Pivel usaba las palabras de otro, como en tantos prólogos, para dar él mismo el golpe. Con la espada de Bauzá en manos de Pivel, Berra sería desangrado lentamente en los diferentes artículos y colaboraciones que Pivel llevara adelante. La anotación era un recordatorio, una advertencia, y un descrédito de lo que luego se leería. Esta cita y la marginalia piveliana volverían a aparecer en uno de los tomos de la Colección.... En el prólogo de la Historia de la dominación..., y haciendo un racconto de las críticas de Bauzá sobre aquellos que se dedicaron a escribir sobre Artigas, citaba nuevamente lo anotado por él en el libro de Berra (Pivel, 1965b, p. 132). La fuerza de la opinión de Pivel parece haber pesado como para que lo expuesto por Berra fuese borrado del imaginario ciudadano y cultural que pretendía consolidar la Colección...

Pero es recién en la Advertencia al tomo XI del Archivo Artigas, donde Pivel aprovechó para criticar algunos puntos flojos de las posturas de Berra que, según consideraba, provenían de la influencia de Bartolomé Mitre. Sobre todo en el conflicto entre Artigas y el gobierno porteño, surgido para elegir diputados para la Asamblea Constituyente de 1813, Berra fue tratado como «no veraz» (Pivel, 1974, p. 62), y con una animosidad notoria, al intentar «trazar la imagen de un Artigas soberbio e insolente y de un gobierno de Buenos Aires circunspecto y tolerante» (Pivel, 1974, p. 61).

Pivel criticó extensamente el Bosquejo... y expresó que

\footnotetext{
${ }^{290}$ Sobre este tema ver Vásquez Franco (2011).

${ }^{291}$ Esta referencia parte de la primera edición de la Historia de la dominación... (1895) que tuvo Pivel en sus manos. La marginalia se encuentra en Berra, Francisco (1881). Bosquejo histórico, Biblioteca Pivel Devoto, Universidad de Montevideo.
} 
La sintética mención que contiene esta obra del rumbo político que tomó la revolución oriental en 1813, debe atribuirse a que el Bosquejo... consta de 146 páginas y a que la juventud del autor no le había permitido aún completar sus conocimientos en una materia aún no estudiada entre nosotros (Pivel, 1974, p. $33)$.

Además, apuntó que «La versión dada por Berra en 1874, desdeñando documentos ya publicados, respondía al objeto de acuñar el perfil de un caudillo levantisco y autocrático, que regía sus actos por la arbitrariedad y el despotismo» (Pivel, 1974, p. 37). Sutilmente, se puede considerar que el argentinismo de Berra gestó un preconcepto que no se rindió ante la documentación histórica disponible.

Luego de repasar las distintas versiones que tuviera el Bosquejo..., Pivel concluyó:

La información y apreciación sobre los hechos del año 1813 hecha por Berra en 1881, no difiere en lo sustancial de lo que realizó en 1895; son menores los detalles; más extensas las consideraciones de orden sociológico, en las que se advierte la influencia de Vicente Fidel López, consideraciones artificiosas, sin vibración humana y desprovistas de sentido histórico. Al igual que Mitre, Berra no sacó partido de las reformas que introdujo en muchos capítulos del Bosquejo para incorporar a sus páginas el fruto de las investigaciones y hallazgos realizados desde 1881 que, como ya dijimos, enriquecieron el conocimiento por tantos años confuso de la Patria Vieja, actitud merecedora de reparos porque era una forma de desconocer un aspecto del progreso de la ciencia, de la evolución de la inteligencia nacional: resabios de una actitud política respecto del caudillismo del que Artigas había sido fundador al impulsar el acceso de las masas a la vida pública (Pivel, 1974, p. 105).

La obra de Berra, que estuvo vigente desde su primera edición en 1866 y que fuera revisada y aumentada en cuatro ocasiones, no era aceptable en un país que comenzaba a ver a José Artigas como el impulsor del joven Estado uruguayo. Pivel, en su papel de «censor», historiador y empleado de la administración estatal, terminó de desterrar y eliminar una de las visiones conflictivas de la nación. En consecuencia, la obra Berra ${ }^{292}$ formó parte del index de libros prohibidos por el Estado uruguayo.

Para hacer frente a los casos citados, había que contradecirlos con pruebas historiográficas contundentes. La reedición de ciertas obras y el olvido de otras tenía como objetivo hegemonizar la discusión, tensando la vara hacia el reforzamiento del sentimiento nacional. El

\footnotetext{
${ }^{292}$ No se agota solamente en Gómez y Berra. Si bien no los trabajamos en este capítulo, hay otros anti-artiguistas (de menor alcance) en la lista, entre ellos Luis Destéffanis, Diodoro de Pascual, Pedro Bustamente y Melián Lafinur.
} 
Estado tuvo a Pivel como un intelectual dispuesto a realizar dicha tarea, y a la Colección... como vehículo para lograrla.

Los autores que no fueron publicados en la Colección... nos hacen ver la importancia e influencia de Pivel en cada una de las decisiones. En primer término, observamos la tarea propia de un editor en jefe, que selecciona aquello que puede ser o no impreso en la colección dirigida. Sin embargo, en el caso de Bula, pudimos avizorar que Pivel fue mucho más allá. Directamente, se le sugirió aquello que tenía que escribir, y al no cumplir con los lineamientos, se lo desechó. En consecuencia, cabe plantearnos: ¿sería la única vez que el editor sugirió un cambio de esta naturaleza?, ¿fue efectivo en otros casos? La documentación existente deja las preguntas sin respuesta, pero podemos arriesgar que no fue algo excepcional.

Posteriormente, observamos una animosidad que se extendió largamente en el tiempo. Si bien Eduardo Acevedo era un autor fundamental que cumplía con todas las premisas para ser publicado por el Estado (pues se trataba de un pro-artiguista con obra erudita, además de ser un intelectual con actuación política notoria, y adjudicatario de múltiples e importantes puestos en la administración estatal batllista), no contaba con el visto bueno de Pivel. En la línea de historiadores que fueron conformando un sentido y una base nacional para la historia del Uruguay, y de la que Pivel se creyó heredero, Acevedo no tenía lugar; por lo tanto, lo mejor era dejarlo de lado en la Colección...

Finalmente, con respecto a los casos de Gómez y Berra, obervamos que había determinados autores que no podían estar, y en este caso Pivel se ocupó no solo de dejarlos de lado, sino también de criticarlos y de desarmar su tímida argumentación, golpeando sostenidamente dichas obras.

El canon se construye sobre la base de lo que se edita y sobre lo que se decide no editar. No solo era imprescindible tener a los autores más representativos de la cultura y la historiografía nacionales, sino también a los críticos más importantes de la época encargados de los prólogos, dándole una impronta actual a los clásicos. Pivel, como censor, estuvo presente en todas las obras que le tocó editar. Hoy podemos leer a quienes comprendieron cuál debía ser el tono pretendido por el editor en el interior de la Colección... Quienes no convergieron con las condiciones de Pivel, no fueron editados.

\section{Cambio de registro}

Sabemos que ser prologuista de la Colección... suponía entrar en un registro ensayístico algo acotado. La mayor parte de los críticos más importantes del país se hicieron cargo de algunas de las obras editadas por el Estado, debido a la confianza que el editor depositaba en ellos. Sin 
embargo, tal como vimos, por más nombre importante que se tuviera, nadie estaba exento de pasar por los ojos del censor.

Al mismo tiempo, la remuneración del trabajo evidenciaba que el principal rédito de intervenir en la colección provenía del valor simbólico de participar de ese proyecto editorial impulsado por el Estado nacional, integrándose al canon de los prologuistas.

En algunos casos parece haber habido un cambio de registro, e incluso de opinión, dependiendo del lugar de publicación y de los editores al frente da cada proyecto editorial. Difícil es probar esta suposición ya que no contamos con registros de los prólogos enviados y corregidos por el censor. En el caso de Bula Píriz pudimos demostrar la censura rotunda; sin embargo, en este punto vamos a sugerir la autocensura, al comparar las distintas posiciones de Alberto Zum Felde frente a la obra que le tocó prologar, teniendo en cuenta comparativamente el prólogo para la Colección ... y otras publicaciones alejadas de la órbita estatal, sobre el mismo tema. Consideramos que tanto la autocensura del autor como la censura de los editores conformaron un aparato crítico paralelo, referenciando las mismas obras clásicas, pero con opiniones dispares. Por lo tanto, es posible pensar que el canon construido no solo fue una selección de obras de autores nacionales, sino que también fue una selección de posturas críticas sobre ellas.

Zum Felde (1889-1976) fue crítico y ensayista importante en el Uruguay de la primera mitad del siglo XX. Nació en Bahía Blanca (Argentina), pero desde muy chico se radicó en Uruguay; perteneció a un hogar de clase media, formado por su padre (Emilio Zum Felde), de origen germano, y su madre (Josefina Alberdi), criolla uruguaya, de ascendencia claramente patricia. No siguió estudios terciarios, por lo que su formación fue autodidacta, como la de muchos cultores de las letras y la historia durante los primeros años del siglo XX (Zum Felde 1930b, p. 321). En su juventud, se vinculó con la intelectualidad modernista del Uruguay, integrando el círculo del poeta Roberto de las Carreras, cuyas reuniones se realizaban en el Café Moka en pleno centro de la actual Ciudad Vieja, en la calle Sarandí. Fue dueño de una obra crítica sólida e importante. Políticamente estuvo vinculado al anarquismo batllista.

Su variada actuación en la prensa montevideana, ${ }^{293}$ ejerciendo la crítica literaria, implicó la redacción de varias obras: Crítica de la literatura uruguaya (1921), Proceso histórico del Uruguay (1920), Estética del 900 (1929), Proceso intelectual del Uruguay y crítica de su literatura (1930), Índice de la poesía uruguaya contemporánea (1933) y La literatura del Uruguay (1939).

\footnotetext{
${ }^{293}$ Publicó notas en diario batllista El Día, luego en su versión vespertina llamado El Ideal, y en la revista $L a$ Pluma, de la que fue director.
} 
Entre sus cargos públicos, fue director de la Biblioteca Nacional entre 1940 y 1944. Gracias a su obra poética, en 1957 se le otorgó el Premio Nacional de Literatura (bienio 19551956) y, en 1968, el Premio Nacional de Literatura (trienio 1964-1967) por segunda vez.

Zum Felde es también recordado por un episodio del que fue protagonista, y que tomó estado público en la época. En 1910, cuando murió Julio Herrera y Reissig, y sin que nadie lo invitara, pronunció durante su sepelio un discurso extremadamente duro y crítico que hizo callar al propio Zorrilla de San Martín, quien se aprestaba a pronunciar él también unas palabras sobre el poeta. En su alocución, el crítico literario acusaba a la sociedad uruguaya por las condiciones duras en las que se había obligado a vivir a Herrera y Reissig durante sus últimos años. Como resultado del incidente, su discurso fue publicado en el diario La Semana. ${ }^{294}$

Con respecto a su actuación como crítico de la Colección ..., Zum Felde fue designado en dos ocasiones como prologuista. En 1955, para llevar adelante el estudio previo de Tabaré (1956, vol 18), de Zorrilla de San Martín, y en 1966, para hacer lo mismo con Obras poéticas de Herrera y Reissig (1966, vol. 113).

Qusiéramos comparar tres estudios críticos de Zum Felde, para observar su cambio de registro. En primer término, el caso citado del prólogo a la edición de Tabaré hecho por el Estado uruguayo. En dicho estudio, de 24 páginas, el crítico literario realizó una reseña formal de la obra, dejando de lado la biografía del autor. Para comparar, haremos referencia al capítulo —bastante más extenso y escrito 25 años antes - sobre Zorrilla de San Martín, publicado en el Proceso histórico..., y el prólogo a Tabaré editado en 1944 (con reedición en 1968) por la editorial argentina Ángel Estrada.

Con respecto a los estudios críticos de referencia para este capítulo, consideramos que existen dos niveles de diferencias. El primero entre el Proceso... y el prólogo a Tabaré editado por Ángel Estrada. Entre ellos, el cambio en la crítica se dio como consecuencia de la transformación del paradigma crítico. Dado que Zum Felde integró aspectos del psicoanálisis, el estudio de Tabaré se vio esencialmente modificado. Sin embargo, en el segundo nivel, las diferencias entre el prólogo de 1944 y el de 1956 parecen ser de forma. Se transcribió prácticamente el mismo trabajo, con algunas modificaciones, donde muchas palabras fueron sustituidas para mejorar la sonoridad y clarificar lo expuesto. Sin embargo, hubo notorias eliminaciones de pasajes enteros, que pueden interpretarse como la autocensura de algunas opiniones. No fue un cambio crítico como en el primer nivel citado, sino algo perteneciente al punto de vista de Zum Felde que quizás no era conveniente editar en la Colección...

\footnotetext{
${ }^{294}$ La Semana (26 de marzo de 1910), Montevideo, año II, n. ${ }^{\text {o }} 36$.
} 
Tabaré, publicado originalmente en 1888 por Barreiro y Ramos, fue una de las obras más resaltadas por la crítica y reseñadas de toda la literatura nacional. El poema fue trabajado en los liceos, dentro de los programas de literatura, como ejemplo de composición patria de tema indígena.

La obra, ambientada geográficamente en la zona que actualmente es territorio uruguayo, durante el siglo XVI, cuenta la historia de amor entre Tabaré, un mestizo mitad indio charrúa, mitad español, y una castellana llamada Blanca, sobre el telón de fondo del enfrentamiento entre indígenas y españoles. En este sentido, Tabaré reelaboró los tópicos más comunes del pacto socio-sexual forjado por la literatura romántica latinoamericana, para imaginar la fundación de la nación como amalgama interétnica, tal como ha sido estudiado por Sommer (2010).

Sin embargo, el crítico uruguayo señalaba que «Forzoso es reconocer que, —exceptuando la novela «Amalia», ${ }^{295}$ por su interés histórico - casi nada sobrevive de la obra literaria de la primera generación romántica platense. Ninguna de sus producciones llega, ni lejanamente, a la categoría de la producción europea de la época, de la cual era simple remedo» $(1944$, p. 16). Claramente, esta sentencia desapareció de la Colección ... ya que no era apta para un panegírico a Zorrilla de San Martín como poeta nacional.

Durante todo el prólogo de la Colección..., Zum Felde concluyó que lo que se buscó fue resaltar la originalidad del poema, y los puntos positivos que la hicieron merecedora de su calidad de «clásico» de la literatura uruguaya (Zum Felde, 1956, p. 23). Sin embargo, si bien el crítico literario acentuó algunos aspectos importantes de la obra de Zorrilla de San Martín, en el Proceso histórico... no se mostró defensor de la totalidad del poema; más bien asumió muchas de sus deficiencias o «flaquezas», preguntándose:

¿Logra «Tabaré», ser expresión cabal y símbolo pleno de aquello que quiere representar?; es lo que debe ser?; se realiza a sí mismo? (sic) A tales preguntas —que implican todo el problema crítico de «Tabaré» solo puede responderse lealmente: hasta cierto punto (Zum Felde, 1930, p. 257). ${ }^{296}$

Sin embargo, repetir determinadas posturas críticas a la hora de presentar el trabajo para la Colección... podía encerrar algunos problemas. Como sabemos, el motivo de editar obras nacionales, por parte del Estado uruguayo, implicaba la idea de estabilizar un canon literario. Si la crítica a un libro que se editaba era negativa, probablemente - como sucedió en el caso de Bula Píriz-, podría quedar afuera de la Colección... En este sentido, es probable que Zum

\footnotetext{
${ }^{295}$ Escrita por José Mármol y editada en 1851.

${ }^{296}$ Falta de signos de interrogación, y cursiva en el original.
} 
Felde reconociera, en el proyecto del gobierno colorado, que era conveniente no decir algunas cosas, y en cambio sostener la importancia de cada autor nacional para la cultura mundial.

Dentro de la Colección..., el prologuista pretendió llevar adelante un necesario estudio previo, ubicando cronológicamente la obra, señalando sus características, adscribiéndola dentro de una escuela literaria y reseñando sus aspectos formales y morfológicos, para finalizar con apreciaciones críticas.

En su prólogo, Zum Felde estableció los antecedentes del romanticismo —en el que ubicó la obra de Zorrilla de San Martín - en América y en Uruguay. ${ }^{297}$ Además, afirmó que Tabaré fue una creación literaria única en su género. Esa afirmación se basaba en que, en el resto de la poesía romántica regional, los personajes estaban armados siguiendo parámetros más bien europeos, frustrando la búsqueda de la originalidad americana y/o rioplatense (Zum Felde, 1956, p. 11).

Para Zum Felde, los mejores exponentes del movimiento romántico en la región fueron Domingo F. Sarmiento, José Hernández y Eduardo Acevedo Díaz. Sin embargo, ellos tuvieron una ventaja respecto de Zorrilla de San Martín, ya que escribieron sobre personajes que se encontraban relacionados con su entorno. En cambio, el poeta objeto de este prólogo tuvo que «operar con una realidad muy lejana, ya muerta en el tiempo e imaginativamente reconstruida, por lo que su labor se presentaba más difícil y peligrosa» (Zum Felde, 1956, p.12).

En el Proceso histórico..., el crítico literario también resaltó la importancia de Zorrilla de San Martín dentro del conglomerado de poetas románticos, al manifestar que era

...el único poeta romántico cuya obra ha sobrevivido a su tiempo; y comparte, con Acuña de Figueroa ${ }^{298}$, el único legado relativamente válido de la poesía del siglo XIX a la posteridad de nuestra historia literaria. Todos sus congéneres — como los congéneres clasicistas de Figueroa — son mencionables solamente como datos históricos, para documentar la vida intelectual de su tiempo y su medio; las cualidades de su producción no alcanzan a valorizarla en sí misma (Zum Felde, 1930, p. 251).

Por tanto, algo que mantuvo en su discurso Zum Felde fue considerar como destacada la actuación que tuvo Zorrilla de San Martín como poeta, y su obra Tabaré, merecedores de integrar un canon nacional debido a virtudes propias y deficiencias ajenas — por la mediocridad del resto de los escritores. El Estado ya había asumido la grandeza y las aptitudes poéticas de

\footnotetext{
${ }^{297}$ Haciendo referencia a Esteban Etcheverría como el introductor del romanticismo en el continente, y a sus posteriores seguidores uruguayos: Adolfo Berro, Juan Carlos Gómez y Magariños Cervantes (Zum Felde, 1956, pp. 9-12).

${ }^{298}$ Acuña de Figueroa fue el autor del himno nacional uruguayo. Zum Felde lo consideró junto a Zorrilla de San Martín como los dos poetas fundamentales del canon nacional. Recordemos que la Colección... editó sus obras en un total 18 tomos, reafirmando su importancia para la centralidad canónica.
} 
Zorrilla de San Martín, al encargarle una obra que tuviera como personaje principal a José Artigas. El resultado fue La epopeya de Artigas, editada en 1910.

Más allá de su importancia para la historia de la literatura uruguaya, el crítico literario manifestó la caída en desgracia de las obras de Zorrilla de San Martín, fomentada por el olvido, además de los cambios de gusto estético:

\begin{abstract}
La gloria de «Tabaré» sufrió un eclipse al entrar en el siglo XX. El realismo literario por una parte, por otra el imperio del «modernismo», apartaron el gusto y el concepto de la élite intelectual, del modo romántico de «Tabaré», haciéndole perder mucho de sus prestigios. Se llegó, inclusive, a la negación casi total de sus méritos. La verdadera posición crítica a este respecto, está, empero, tan lejos de esta negación radical — aún persistente en ciertos sectores juveniles - como de aquella admiración absoluta que el poema de Zorrilla llegó a gozar en otros lustros (Zum Felde, 1930, p. 254).
\end{abstract}

En cambio, dentro de la Colección... ese olvido en el que supuestamente ya se encontraba la obra en 1930, fue dejado de lado. Evidentemente el romanticismo de Tabaré caía fuera incluso de lo legible, excepto como documento de la historia literaria, lo cual exigía una preparación historiográfica de parte del lector de las capas medias. Justamente, la idea del prólogo era preparar al lector medio para leer un texto cuyo parámetro estético caía fuera del gusto hegemónico de su presente, ampliando su horizonte de expectativas (Iser, 1987).

Otro de los aspectos manejados en la mayoría de los prólogos era el «rescate del olvido» de las distintas obras. En el caso de Zorrilla de San Martín, también parecía ser la norma, ya que, como decía Zum Felde, el olvido le había llegado de manera irremediable, y mantener vivas las obras fundamentales del nacionalismo cultural uruguayo era uno de los fines que perseguían las ediciones del Estado. Sin embargo, como veremos más adelante ${ }^{299}$, Zorrilla de San Martín siempre gozó de la centralidad canónica al ser editado en todas las colecciones privadas literarias del siglo XX y en las panorámicas de la historia de la literatura nacional.

Además, cuando era momento de realizar una crítica negativa sobre Tabaré, Zum Felde olvidó, recortó y autocensuró partes de lo escrito en el Proceso histórico... y en el prólogo de 1944. Estos recortes fueron hijos del cambio de paradigma en la lectura llevada adelante por el crítico, y en algunos casos, como consecuencia de editar sus opiniones dentro de la Colección... Por ejemplo, respecto del protagonista, el indio Tabaré, Zum Felde observó en dicho libro dos flaquezas en su construcción. La primera daba cuenta del invento en sí del indio «sin apoyo en la historia o en la leyenda» (Zum Felde 1930, p. 258). La segunda, como símbolo, 
Aun puesto en el trance de crear imaginativamente su protagonista, por no hallar en la historia ni en la leyenda el que sirviera a sus designios poemáticos - el poeta pudo, y debió, haberlo formado por síntesis de los caracteres genuinos de su raza, a fin de que fuera su representación típica-. Pero no lo hizo así: creó un personaje de excepción, un ente por completo singular, a cuyo origen concurren también supuestas circunstancias, no menos excepcionales; no es por tanto este indio o mestizo un tipo representativo de su raza, sino una concepción un tanto arbitraria (Zum Felde, 1930, p. 259).

La historia de Tabaré le parecía una construcción arbitraria, sin un buen fundamento histórico. Al presentar al protagonista como una excepción, Zorrilla de San Martín equivocaba su camino. En cambio, en el prólogo de 1944 y en el hecho para la Colección..., Tabaré es presentado como un personaje verosímil si se lo piensa desde el punto de vista de la creación subconsciente por parte del autor, y en última instancia no tan importante para el verdadero significado de todo el poema:

Dadas las circunstancias y la anécdota imaginada por el autor - $\mathrm{y}$, en especial, esa reminiscencia de su llorosa madre blanca, y de su infancia arrullada por oraciones, flotando en su subconsciente - Tabaré es, empero, un personaje verosímil; y esta verosimilitud de caracteres salva, en cierto modo, la ausencia de aquella verdadera entidad histórica procedente de la tradición en que se basa la poesía épica [...] el nacimiento del mestizo Tabaré, híbrido de sus sangres, pudo haber ocurrido, puesto que se sabe que ocurrieron casos semejantes en los asaltos que los indígenas llevaban a los fortines y poblaciones de los españoles (Zum Felde, 1956, pp. 14-15).

Tabaré pasó de ser una creación sin base histórica, a presentar rasgos verosímiles, ya que lo que cambió fue el punto de vista del crítico: en el primer caso se lo juzgó desde el realismo estético, en el segundo, desde la dimensión subconsciente que regía la escritura. También dejó de ser indio o mestizo para pasar a ser mestizo, a secas. El discurso cambia porque es el propio Zum Felde el que madura en sus posturas críticas, pasando del impresionismo amateur a posiciones estéticas sui generis.

Por otro lado, en el Proceso histórico..., terminó afirmando que el protagonista del poema tenía que ser Yamandú y no Tabaré (Zum Felde, 1930, p. 264), mientras que, en la Colección..., solo se lamentaba de que Yamandú, siendo el más original de los indios, tuviera tan poco lugar en la obra. Sin embargo, lo consideraba coherente ya que tenía que desaparecer porque no era el protagonista (Zum Felde, 1966, p. 20).

Coherente con este planteo, en el prólogo para la Colección..., Zum Felde eliminó dos párrafos sobre Yamandú presentes en la edición de 1944: 
Como protagonista del poema, el cacique Yamandú sólo pertenecería al pasado de la raza aborigen, desaparecida para siempre en esta banda del Plata, borrada de su historia futura. Tabaré, en cambio, hijo de una española cautiva y de un jefe charrúa, acunado entre lloros y rezos, en medio de la primitiva soledad de los bosques, tiene ya su perfil triste vuelto hacia la posteridad de la herencia [...]. Los mestizos indo-hispanos que conoce la historia, y la tradición recuerda, fueron rudos gauchos de nuestras guerras y de nuestras faenas de estancia, cuando no matreros o milicos (Zum Felde, 1944, p. 34).

Posteriormente el crítico literario borró un pasaje de una página, en donde se refería a la influencia del poeta irlandés Ossian (también influencia de Goethe,y por tanto de las Cuitas del joven Werther ya mencionadas en el prólogo de 1944). Con relación al carácter lírico del Tabaré, Zum Felde afirmó que

... la concepción de Zorrilla procede más bien de la sugestión ossiánica [...] La genial impostura del poeta inglés, cuyo espíritu ha sido, por ironía, una de las presencias más vivas y dominantes en toda la lírica del romanticismo, ejerció sobre Zorrilla de San Martín, como sobre muchos poetas europeos de su tiempo, un hechizo supremo. El autor de TABARÉ estaba hondamente empapado de Ossian; y a su tiempo que escribía su poema, traducía al verso castellano algunos de esos Cantos del Norte, que pueden, paradójicamente, llamarse engaño verdadero (Zum Felde, 1944, pp. 35-36). ${ }^{300}$

En cambio, al inicio del prólogo editado por el Estado, puede leerse: «Zorrilla de San Martín amaba a Ossian —vivo aún el culto de su genial impostura-y estaba profundamente empapado de su grandeza melancólica; tanto que, a tiempo mismo de concebir "Tabaré", vertía al verso castellano fragmentos de aquella ficción nórdica» (Zum Felde, 1956, p. 9). ${ }^{301}$

Lo llamativo es que, eliminada esa cita, el prólogo en la Colección... continúa prácticamente sin ningún cambio (Zum Felde, 1956, pp. 20-21). Por lo tanto, la extracción de dichos párrafos fue directamente pensada para hacer desaparecer de la crítica anterior esa relación de Zorrilla de San Martín con Ossian, que quitaba ciertas características auténticas del mayor poeta nacional uruguayo.

Finalmente, en el Proceso histórico..., Zum Felde terminaba de criticar la obra, enfrentándola a sí misma, ya que no tenía contendientes con los cuales compararla. Afirmaba que

... no es que debamos considerar a «Tabaré» obra de alta perfección literaria;

al contrario, tiene grandes defectos; y no con respecto a otros cánones y

\footnotetext{
${ }^{300}$ La mayúscula del original y el destacado es mío.

${ }^{301}$ El destacado es mío.
} 
perspectivas cualesquiera, sinó [sic] con respecto a sí mismo, a su intrínseca naturaleza, a lo que quiere expresar y tiende a ser (Zum Felde, 1930, p. 256).

Si bien en la cita, uno de los problemas que espetó el crítico literario fue la incapacidad de Zorrilla de San Martín para decir lo que quería expresar, en el prólogo de la Colección..., la opinión fue en sentido contrario. A medida que pasaban las páginas, parecía que el Zum Felde prologuista oficial quería convencer al Zum Felde crítico literario de 1930. La forma que encontró el autor del prólogo para justificar esos supuestos problemas en la obra, fue el «símbolo poético»:

En la realidad histórica, el fenómeno del mestizaje, en lo que respecta a Uruguay, no da los caracteres de que Zorrilla dota a su personaje epónimo. Pero hay que tener en cuenta que Tabaré es solo un símbolo poético y no una realidad histórica (Zum Felde, 1956, p. 16).

La importancia que el crítico le dio a la historia, e incluso el halago de lo documentado que estuvo Zorrilla de San Martín respecto a los charrúas, para escribir sobre la tribu de Tabaré, se perdió al defender el poema por su carácter simbólico y desechar la realidad étnica del Uruguay. Recordemos que Tabaré era un mestizo, mitad español y mitad indio, «híbrido de ojos azules y de cuerpo de bronce, extraña sombra de pelo hirsuto y de corazón blando» (Zum Felde, 1956, p. 16).

Fue en la poesía de Zorrilla de San Martín en donde se mezclaba un ingrediente importante para toda su anterior y posterior literatura, el cristianismo: en «su alma oscura [...] se confunden la primitividad salvaje de su tribu y la sentimentalidad caballeresca de los héroes cristianos» (Zum Felde, 1956, p. 16). Este personaje romántico, al estilo europeo -como decía Zum Felde-, fue el que quiso confeccionar Zorrilla de San Martín, aunque incurrió en un supuesto error, que veremos no terminó siendo tal:

Tabaré ama a Blanca, la doncella española, con ese amor puro, hecho de casta adoración y de sublime sacrificio, que es un rasgo característico de la literatura romántica. Podría observarse que el autor incurre en cierto anacronismo, puesto que da a un mestizo del siglo XVI rasgos característicos del estado de alma europeo de tres siglos más tarde, de aquél en que el autor concibe y escribe el poema, dotando al personaje creado de su propia sentimentalidad. Sin embargo, y aún reconociendo que lo predominante en la concepción de esta figura es su valor simbólico y que, por lo tanto, él representa una verdad poética mas que una verdad estrictamente histórica, advertiríase que, a la luz de la más avanzada ciencia psicoanalítica de nuestros días, la casta pasión del mestizo por la doncella española puede tener su entera explicación en aquella profunda reminiscencia de infancia (Zum Felde, 1956, pp. 16-17). 
En la larga cita, se detectaban nuevamente dos de los problemas del poema que fueron señalados por Zum Felde. Por un lado, el alejamiento de la realidad histórica, y por otro, el anacronismo en la psiquis del protagonista. Sin embargo, desde su paradigma crítico esta aparente contradicción era superada en el ámbito simbólico; en su lectura plantea que el subconsciente del autor estaba centrado en el mestizaje y que ello se proyectó en la construcción del personaje.

Sin embargo, lentamente la crítica se desvaneció bajo los efectos del panegírico, del servilismo discursivo, coherente con lo pedido por el Estado nacional. Reafirmar, incluso bajo el efecto de los errores, la supuesta maestría de la obra, era lo mejor que podía tener un prólogo del nuevo canon oficial.

Entonces, los dos problemas fueron solucionados a través del simbolismo del poema y de la psicología, que pudo dar sentido y verosimilitud a la construcción hecha por Zorrilla de San Martín en la obra que estudiamos.

La autocensura, llevada adelante por Zum Felde fue fundamental para que pudiéramos comprobar que los prólogos de la Colección ... estuvieron más cerca de las alabanzas a las obras, que de la crítica realizaba con cierta libertad.

\section{Conclusiones parciales}

Entendemos que la Colección ... fue un proyecto que pasó por varias manos y distintos partidos políticos y regímenes de gobierno en sus más de cincuenta años de historia. Sin embargo, la amalgama de todas estas variables terminó siendo Pivel.

La censura llevada adelante por la Comisión tuvo diferentes aristas: desde las exclusiones conscientes de algunos nombres que no servían al proyecto historiográfico de la nación, hasta algunos prologuistas que no cumplían con los postulados sugeridos por el editor en jefe.

En el caso de Eduardo Acevedo, si bien fue un historiador de renombre durante principios del siglo XX, Pivel tenía una larga enemistad con él que lo volvía poco elegible. El editor pensó que la Colección... también tenía que ser un canon de libros de historia, y en la nómina de autores se tendría que observar quién poseía el título de heredero nacional. Desde la publicación de Bauzá, pasando por de la Sota, de María y Blanco Acevedo, el que quedaba por editar era Pivel. La autoconsagración y el intento de hegemonización del discurso nacional historiográfico hizo que Acevedo quedara fuera de la serie.

En el caso de Bula, nos encontramos con un tipo de censura visible, activo e incómodo. Pivel no dudó en marcar los desatinos a los que, según sus repetidas y molestas consideraciones, el crítico literario había incurrido. En este caso, el editor se encontró con un orgulloso crítico que no quiso cambiar un ápice lo que había escrito. Conjeturamos que las opiniones que tuvo 
para con Agustini fueron mal vistas por lo sensible del tema de su muerte y por el estilo romántico con que fue relatada la violencia del crimen. La sustitución de Bula por de Cáceres es un síntoma de cuál era el tono que se buscaba para los prólogos.

Por otro lado, entendemos que la autocensura es más difícil de demostrar. El cambio de discurso puede explicarse por el cambio de postulados metodológicos, ideológicos o de otra índole. Sin embargo, creemos que el caso de Zum Felde, de alguna manera nos acerca a entender cómo publicar un estudio previo a un texto dentro de la Colección... podía llevar a dejar algunas cosas fuera, para evitar choques con los editores para solventar más adecuadamente el edificio nacional. 


\section{CONCLUSIONES GENERALES}

En esta tesis doctoral, nos propusimos como objetivo principal estudiar a dos protagonistas del campo cultural e intelectual uruguayo de la segunda mitad del siglo XX: la Colección de Clásicos Uruguayos y Juan E. Pivel Devoto.

En primera instancia, describimos la materialidad de toda la serie de libros, sus dispositivos discursivos, las decisiones editoriales por parte de sus editores, la selección de obras y autores y demás resoluciones dentro de su círculo de producción. Posteriormente, nos centramos en Pivel su más importante editor, estudiando sus primeros años, la conformación de sus redes intelectuales, y su lento y firme ascenso político y administrativo dentro del Estado, para luego examinar su diversa y extensa obra. Debemos destacar que, en este caso, utilizamos como fuente, por primera vez, la Biblioteca privada de Pivel, que consideramos fundamental para la reconstrucción de sus redes intelectuales.

La Colección... fue el proyecto editorial de índole oficial más importante de la historia del Estado uruguayo. Para responder sobre su éxito dentro del mercado editorial nacional solo nos basta una visita a una librería de usados o a una biblioteca pública, para encontrar en sus anaqueles al menos algunos de sus tomos.

En la Colección... puede observarse el proyecto de nación que se pretendía llevar a cabo, desde un sector del campo intelectual, representado por la política editorial que encabezaba Pivel. A pesar de que la identidad nacional cultural había sido un tema fundamental para la clase dirigente desde el siglo XIX, hasta la aparición de la Colección... no había habido un proyecto editorial capaz de definir la identidad nacional en términos literarios e historiográficos.

Las diferentes comisiones editoras buscaron que la serie de libros fuera reconocible para el público lector al adoptar el sobrio color verde que cubre sus tapas. Materialmente, se intentó hacer económico el precio del tomo para multiplicar su posibilidad de venta. Esto le jugó en contra a la Colección... ya que muchas librerías y exportadores preferían no tenerlos por el bajo nivel de ganancias. Sin embargo, la cantidad de ejemplares que se imprimían por tomo hablaba de una perspectiva y proyección muy optimistas. Durante el período estudiado, podemos afirmar que la Comisión Editora cumplió con el objetivo primordial de vender los tomos, muy a largo plazo, y hacer a la Colección... reconocible en el mercado editorial. 
Debemos destacar que la mayoría de la nómina de libros estudiados por esta tesis se encuentra agotada, ya sea por la venta de los ejemplares, como por los repartos a repositorios públicos y privados, y por las constantes ventas de grandes paquetes en oferta como forma de hacer espacio en los depósitos estatales. Es más, respecto a los tomos analizados, algunos tuvieron un prominente éxito de ventas, sobre todo en los años cincuenta donde la producción de libros uruguayos era muy escasa, reflejado en la venta total de sus primeras ediciones y la necesidad de reimpresiones. ${ }^{302}$

Por otro lado, la efectividad del proyecto también es observable al ser la única serie de libros, con pretensiones canónicas tanto en literatura como en historiografía, que continúa saliendo al día de hoy en Uruguay. Sin embargo, los intentos por extender su zona de influencia más allá del mercado editorial nacional fueron infructuosos. El momento de mayor producción e impresión de títulos de la Colección..., durante la década del sesenta, coincidió con la aparición de nuevas editoriales nacionales y sudamericanas que cooptaron al amplio público lector, el cual se volcó a los autores del boom de las letras latinoamericanas. Por tanto, la experiencia de recepción de la Colección... varía desde el punto de vista de su éxito en el mercado editorial: pasa de tener un papel protagónico, a adoptar un rol cada vez más secundario por la explosión de las publicaciones contemporáneas nacionales, para quedar finalmente relegada a un reducido público de especialistas.

Desde la Comisión Editora se buscó conscientemente huir de polémicas dentro del campo cultural, seleccionando a aquellos autores que ya habían sido marcados por la crítica literaria y los historiógrafos como fundamentales para la conformación de la ciudadanía uruguaya. Esta idea conservadora del canon se mantiene hasta el día de hoy, donde su actual director, Wilfredo Penco, busca seguir interpretando el espíritu de Pivel, su más importante editor.

A lo largo de nuestra investigación hemos demostrado que formar parte del catálogo de la Colección... implicaba una consagración para las obras y sus escritores.

La figura que se destacó, dentro de los más de setenta años que tiene el proyecto, fue Pivel. Este historiador, editor, intelectual, militante político, funcionario público, entre otras funciones, tuvo una fundamental participación en casi todas las etapas del proceso de producción de cada uno de los tomos de la Colección....

Pivel, desde su juventud, se fue forjando como el intelectual oficial del Estado, al aprovechar sus redes intelectuales para acceder a su primer puesto de poder dentro de la

\footnotetext{
${ }^{302}$ El caso de Ismael de Acevedo Díaz (tomo 4) es quizá el más significativo.
} 
administración. Desde allí, y de manera ininterrumpida hasta 1982, pretendió gestar un ámbito de producción historiográfica apegada a su visión del pasado del Uruguay y gracias a la poca profesionalización del medio.

Hemos observado cómo desde su adolescencia, Pivel comenzó a forjar sus lazos con docentes que más adelante le permitieron ir formándose como historiador amateur. Además, sus vínculos como militante del Partido Nacional y con el caudillo Luis Alberto de Herrera le permitió ir posicionándose en lugares hegemónicos.

Sin embargo, no debemos darle todo el crédito a sus vínculos intelectuales, hay que reconocer que el discurso historiográfico piveliano se amoldaba a su contexto histórico. El Poder Ejecutivo, en el Uruguay de los años cincuenta y sesenta, fue compartido por los dos partidos políticos mayoritarios, con la configuración del colegiado. Con esto se ponía fin al duro enfrentamiento que ya tenía más de un siglo de desarrollo. El relato de Pivel sirvió para amalgamar a las dos entidades políticas partidarias más importantes de la Historia del país. Además, el aparato erudito utilizado y el estilo literario que tuvo en sus libros y prólogos, hizo mucho más fácil la tarea de consagrar el discurso historiográfico piveliano como el oficial del Estado uruguayo.

Desde la llegada al Museo Histórico Nacional, Pivel se aseguró un lugar en la puja por la hegemonía discursiva que hasta ese momento había pertenecido a figuras de la historiografía colorada. Inteligentemente, su postura conciliadora de los héreos nacionales también la practicó con los historiadores colorados. Como vimos en el prólogo a Bauzá, su historiografía se construyó como amalgama, agregando los tintes blancos al discurso colorado hegemónico.

Una vez creada la Colección..., en 1953, Pivel pasó a ocupar un lugar en la Comisión Editora ya que cada uno de los directores de los tres repositorios documentales del país tenía un puesto asegurado junto con el Ministro de Instrucción Pública del momento. Con esta posición de privilegio participó en la toma de decisiones, y conoció desde el principio el sentido del proyecto editorial.

Esta posición hegemónica dentro del campo intelectual le permitió repartir dineros públicos entre los nuevos integrantes de sus redes intelectuales, a través de la publicación de obras y artículos, mediante concursos estatales y recomendaciones personales.

La posición hegemónica de Pivel, en el campo intelectual, coincidiría con la victoria electoral, por primera vez en 93 años, de su partido político, conduciéndolo a ser parte del Poder Ejecutivo. Una vez al frente del Ministerio en 1963, se encargó de seleccionar a los autores y títulos de la mayoría de la serie estudiada. Si tenemos en cuenta que, dentro de su gestión se publicaron 166 tomos de los 200 que tiene actualmente la Colección..., entendemos que esta 
serie mantiene, aún hasta el momento, una impronta mayoritariamente piveliana que sigue siendo, como dijimos, compartida por el actual director.

Sin embargo, ¿qué es lo piveliano? Entendemos, luego de este trabajo, que es esa impronta que tanto los libros como los prólogos y demás características del proyecto tuvieron durante el período estudiado y más allá. Lo caracterizamos como una amalgama entre posturas historiográficas que buscaron un relato homogéneo de lo nacional, ideologías de tinte conservador, fuerte estatismo, neutralidad política entre los dos partidos tradicionales - blanco y colorado - y una importante influencia directriz llevada adelante por nuestro protagonista.

Lo piveliano, decimos, tiene tintes conservadores y estatistas. Pivel se mostraba como un ferviente católico, en su momento emparentado con el falangismo español, y contrario a los postulados de la izquierda decimonónica. Su pretendido catolicismo se observó oportunamente en varias decisiones que tomó como editor. Cuando trabajamos con el prólogo de Agustini, notamos un cierto decoro en el trato para con su biografía. Además, en muchas oportunidades, y cuando se trataba de prologar a autoras, Pivel encargó la redacción de dichos estudios prelimiares a Esther de Cáceres - otra católica conservadora- quinen fuera una de sus discípulas intelectuales. Su manera de concebir la nación fue asumida por la dictadura militar en su discurso de unión de todos los orientales, por más que él fuera contrario a los gobernantes de facto.

Con respecto a su postura historiográfica, debemos recordar que hubo dos libros fundamentales en la bibliografía básica redactada por Pivel: la Historia de la República Oriental del Uruguay 1830-1930 (1945) y la Historia de los partidos y las ideas políticas en Uruguay (1956). Desde esos libros ensayó una visión neutra, aunque más apegada al Partido Nacional - por tanto, blanca-, y teleológicamente "condenada" a la unificación partidaria en favor de la nación.

La selección de historiadores, por parte de la Comisión, terminó consagrando a Pivel como el último eslabón de la cadena de la historiografía nacional. Como hemos visto, incluso desde los prólogos - mayoritariamente hechos por el mismo Pivel-, la importancia de remarcar los puntos fundamentales de su propio discurso historiográfico llevaba a concluir que naturalmente todos los autores sostenían de manera monolítica posturas en favor de la obra historiográfica piveliana.

Inteligentemente, Pivel reforzó su relato autobiográfico como un prócer de la historiografía nacional, borrando sus marchas y contramarchas de su archivo documental privado - hoy en manos del AGN-, y apadrinando a los futuros historiadores que terminaron hegemonizando el campo historiográfico luego de la dictadura. El caso más representativo fue el de José Pedro Barrán, que trabajó para Pivel bajo la Colección..., y que desarrolló su obra 
historiográfica por caminos diferentes respecto de los pivelianos, lo que le valió posteriores enfrentamientos hasta que, hacia el final de su vida, volvió a rendir homenaje a su antiguo maestro.

Pivel fue efectivo al crear una imagen de él que ciertamente es difícil de desentrañar. El ejemplo más llamativo para este tesista fue el de su ferviente catolicismo. Si uno observa su accionar y sus redes, además de sus vínculos insitucionales y declaraciones ante la prensa, y sus producciones intelectuales, sería dificil dudar de que Pivel fuese un católico practicante ${ }^{303}$.

Con respecto a la literatura, la Colección... buscó conformar un canon literario oficial. La centralidad de dicho canon fue ocupado por Zorrilla de San Martín, que ya tenía la aceptación unánime de la crítica uruguaya. La pequeñez del cielo literario uruguayo no dio lugar a la muerte estelar, sino más bien a la suma de cuerpos celestes en la oscuridad literaria nacional.

El accionar de Pivel dentro del plano literario remite a un intelectual que buscó establecer un equilibrio armónico — tanto epistemológico como político- entre distintas posturas, permitiendo una integración simbólica superadora de las diferencias políticas y estéticas, directamente relacionada con su visión "armónica" de la identidad nacional. Ese ideal de armonía integradora - en base al cual se incorporaron autores de diversas vertientes políticas, neutralizando así las tendencias del Partido Colorado y del Partido Nacionalpermite entrever, indirectamente, el conservadurismo político de fondo que alienta su editor ya que, en última instancia, tiende a producir una visión a-conflictiva de la nación, por encima de cualquier lucha de clases y/o enfrentamiento político.

Ese conservadurismo político se traduce, en el campo estético, en la selección de autores y textos vinculados sobre todo a la novela histórica decimonónica, el realismo/naturalismo y/o la "cultura modernista" de entresiglos, negándole así visibilidad a las producciones de vanguardia que eclosionan desde la década del veinte, y que reaparecen con fuerza en las escrituras de Felisberto Hernández, Juan Carlos Onetti o Armonía Somers — solo por citar algunos de los principales nombres de la renovación estética y de la experimentación formal desplegadas en el mismo período en que Pivel dirige la Colección...-. Esos autores quedan excluidos de la Colección..., lo que refuerza su perfil estético conservador.

\footnotetext{
${ }^{303}$ Sin embargo, ante la consulta con su hijo sobre el catolicismo de su padre, la respuesta fue categórica: "mi padre no era católico para nada" (Ver Entrevista a Juan Pablo Pivel).
} 
En el estudio de los prólogos que hemos realizado, intentamos demostrar la importancia fundamental que la Comisión Editora otorgó a este dispositivo de control de lectura, ya que se seleccionó cuidadosamente a los autores, muchos de los cuales ya contaban previamente con prestigio académico e intelectual. Este punto fue uno de los más conflictivos que tuvieron los editores. Como observamos, dio lugar a la censura de prologuistas.

Para las obras historiográficas, Pivel se encargó de la mayoría de los prólogos ya que desde allí se pretendió resaltar la coherencia que los autores anteriores a él tenían respecto de la identidad nacional, no solo seleccionando las obras a editar, sino también marcándolas con su impronta simbólica e interpretativa. Eso le valió ser el prologuista más abundante de la Colección..., contando por ejemplo, tal como vimos, con un prólogo que se extendió por dos tomos — algo único hasta el momento-.

El director de la colección hegemonizó las interpretaciones de las fuentes editadas, al controlar el contenido de los prólogos, que operaban como dispositivos textuales estratégicos en este sentido. Es posible que los autores que intervinieron como prologuistas — aún las figuras disidentes ligadas a la izquierda y/o a proyectos estéticos radicales- "negociaran" implícitamente una lectura afín al perfil ideológico conciliador - $-\mathrm{y}$ también a la estética antivanguardista - dominante en la Colección..., incluso cuando en otros espacios editoriales y críticos esas mismas fuguras promovían experiencias estéticas y culturales rupturistas.

Desde la introducción general del primer tomo, la Colección... se propuso establecer un pacto de lectura amplio, que interpelara a un lectorado masivo por encima del mundo universitario; sin embargo, los prólogos solían presentar un nivel elevado de erudición que contradecía, al menos en parte, ese objetivo de democratización cultural extendido.

Luego de la muerte de Pivel, su inmensa obra historiográfica y de editor sigue en pie. Con respecto a su discurso historiográfico, algunos de sus discípulos ${ }^{304}$ comenzaron a distanciarse respecto del nacionalismo piveliano, golpeado fundamentalmente en dos períodos: desde la colonia hasta la independencia en 1830, y su historia de los primeros años del siglo XX. Además, gran parte de su mirada sobre los primeros setenta años de vida del Uruguay independiente siguen teniendo el peso de antaño. Sin embargo, sus obras historiográficas se leen cada vez menos. Casi no existen reediciones, y solamente es leído por el público de especialistas y académicos. El éxito de su obra editorial superó el de su tarea historiográfica

\footnotetext{
${ }^{304}$ El caso más importante es el de José Pedro Barrán, que si bien estuvo enemistado con Pivel durante mucho tiempo, al final de su vida terminó recordando y rindiendo homenaje a quien consideró su maestro. Ver Barrán (2010).
} 
Esta tesis de doctorado intentó demostrar cómo la idea de la nación cultural — historiográfica y literaria para los casos que nos ocuparon - fue desarrollada desde un proyecto editorial estatal. La Colección... buscó configurar, con su importante aparición en el mercado uruguayo, una selección canónica que sigue siendo ampliamente exitosa.

Al concluír esta tesis hay preguntas que no hemos podido responder, y que quedarán abiertas para posteriores avances (quizás de posdoctorado), relacionadas con la dictadura y Pivel. Si Pivel reafirmaba su compromiso democrático de manera constante en sus discursos, ¿cómo pudo mantenerse en su puesto público hasta 1982? ¿Hablamos de éxito cuando observamos el discurso de nación que elaboró Pivel durante toda su carrera historiográfica y editorial, y que luego fue asumido por la dictadura sin grandes diferencias? Dicho éxito ¿fue la razón de su fracaso posterior, al generarse una reacción mayoritaria contra el legado cultural y político de la dictadura...?

Estas preguntas, entre otras, permanecen aún sin respuesta, y pueden guiar futuros desarrollos, permitiéndonos ahondar en otras aristas que la tesis deja entrever, y que quedan aún sin ser resueltas. 


\section{APÉNDICE A: DOCUMENTO}

\section{BIBLIOTECA ARTIGAS}

\section{Pliego de condiciones particulares}

Licitación pública para la formulación de precios por la composición e impresión de los volúmenes de la «Biblioteca Artigas».

Artículo 1: los proponentes deberán cotizar precios por pliegos, según el cuerpo de composición que se utilizara, y que es el que se indica a continuación.

a- pliegos de 16 páginas, en cuerpo 10/10, medida 18, composición corrida, páginas de 36 líneas.

Art 2: en los precios por los pliegos serán impresos en papel media pluma extranjera de 30 kilos

Art 4: deberán cotizarse precios por la impresión de mil ejemplares de estos pliegos en papel offset de $80 \mathrm{~kg}$, y en papel obra 1a de $45 \mathrm{~kg}$.

Art 5: el formato de la página será de $12 \frac{1}{2} 2$ x 19 centímetros

Art 6 deberán cotizarse precios por página de grabados, en papel ilustración de 43 kilos

Art 7: deberán cotizarse precios por tres mil y cinco mil caratulas a una sola y a dos tintas, en papel nacional para caratula, serie 112 .

Art 8: deberán cotizarse precios de tres mil y por cinco mil ejemplares de cada volumen.

Art 9: la firma a la que se adjudique la presente licitación tendrá a su cargo la publicación de los primeros veinte títulos de la biblioteca artigas

Art 10: lo que no se establece en el presente pliego, se regirá por el pliego general de condiciones

Montevideo, 12 de noviembre de $1951 .{ }^{305}$

\footnotetext{
${ }^{305}$ Caja 128, Carpeta 407, folios 25 y 26.
} 


\section{APÉNDICE B: ENTREVISTAS}

Las entrevistas realizadas en esta tesis tuvieron como objetivo indagar sobre algunas cuestiones que se me presentaron un tanto oscuras, y en otros casos reforzar ciertas hipótesis que fui generando durante la investigación. Busqué otorgarle cierta humanidad a la frialdad de la documentación. El testimonio de muchos que lo conocieron y trataron de primera mano, me permitió avanzar con más fuerza en varias de las hipótesis.

Hice cuatro entrevistas: a Julio Mosses que fue un importante librero a nivel nacional y regional, que estuvo al frente de la Librería Oriente y Occidente y fue quién se encargó de vender muchos de los libros de la biblioteca de Pivel que poseían cierto valor para los coleccionistas. La segunda fue a Wilfredo Penco, actual director de la Colección.... La tercera a Guillermo Vázquez Franco, historiador y compañero de Pivel en Marcha, y la última de forma virtual al hijo de Pivel, Juan Pablo.

Lamentablemente, cuando hice la entrevista a Pivel hijo, no pude cruzar la información con Julio Mosses, que ya había fallecido. Con Mosses me preocupé sobre la biblioteca privada de Pivel que él conoció antes de su llegada a la Universidad de Montevideo, además de su relación con Pivel. Y con su hijo me intenté acercar al Pivel no académico, al que se ocultaba tras los papeles.

Con Wilfredo Penco busqué ver si los lineamientos establecidos por Pivel eran tomados en cuenta en la nueva etapa de la Colección..., y me encontré con que Penco (también integrante del Partido Nacional) busca emular en la selección de textos y autores, así como en las características físicas de la colección, a quien fuera su antiguo director. 


\section{Entrevista a Julio Moses ${ }^{306}$}

Me encuentro en su extensa, poblada, y clásica librería ubicada en Rincón 609 dentro de la Ciudad Vieja. Julio Moses comenzó a vender libros en 1969 siendo muy joven, y tan solo tres años después compró Oriente y Occidente a la viuda de Luis A. Mencker ubicada en la calle Cerrito. ${ }^{307}$ Su especialidad son los libros antiguos, donde se encuentran primeras ediciones, que, según sus propias palabras, no hallan comprador en nuestro país, por lo que muchas veces debe recurrir a la venta al exterior. Un ejemplo, son las primeras ediciones de El Astillero y El Pozo de Juan Carlos Onetti, que por su alto precio ${ }^{308}$ para el mercado local, no se han podido vender.

Adentrándonos en el local, lo encontramos sentado en un sofá, frente a una mesa ratona poblada de libros, entre ellos, dos ejemplares de la Colección que casualmente estaban allí. Luego de unas breves palabras de introducción, gentilmente accedió a la entrevista que a continuación se transcribe.

NG: ¿Cómo puede describir la Colección de Clásicos Uruguayos?

JM: En un principio la intención era hacer una edición económica, razón por la cual el papel era muy malo. Pero hay que ver en la época qué era lo que interesaba, si editar el libro o hacerlo con buen papel, pero los costos... En general, se editaron todos en Monteverde o en Barreiro.

NG: Usted, como librero que practica la profesión desde el año 1969, ¿qué importancia tuvo la Colección?

JM: Tiene su importancia, muchos de ellos son buscados, y están agotados, eso significa que tuvieron o tienen un interés. Hay muchos textos que son únicos prácticamente, los prólogos son muy importantes. El prólogo de Pivel Devoto de Historia de la dominación española en el Uruguay, por ejemplo, es inmenso, dos volúmenes sobre [Francisco] Bauzá, y no hay otro. Además, ayudó demasiado a la gente que los hizo. Prácticamente toda la intelectualidad estaba metida ahí dentro. Hay algunos textos como el de Osvaldo Crispo Acosta, que quizás no interesen, pero no sabemos qué va a pasar dentro de cincuenta años, de repente sea muy importante. Fue la visión de alguien que dijo: «Vamos a meter acá lo mejor que tenemos».

NG: Entonces, ¿cuál sería el criterio de selección a su entender?

\footnotetext{
${ }^{306}$ Realizada en Montevideo el 5 de julio de 2013.

${ }^{307} \mathrm{http}: / /$ www.mosesbks.com/indice.php?part=about-us, — - visto el 5 de enero de 2013.

${ }^{308}$ En el momento de realizada la entrevista costaban quinientos dólares.
} 
JM: Era la cabeza de Pivel, que no sé cómo funcionaba, ojalá supiera cómo funcionaba. Pero realmente no lo sé. Creo que el prólogo de Soledad era de Francisco Espínola. Eran los grandes del momento. Hoy en día no sé cómo lo verá la gente. [...] Son raras las colecciones completas de Clásicos Uruguayos, actualmente no sé en cuántos andan.

NG: 193.

JM: Incluso hay uno que le dedicaron a Pivel que es sobre la leyenda negra, ahí ya cambiaron el papel, las tapas, es de otra calidad. Pero hay que considerar también que hoy en día no hay una calidad tan mala como la de aquel entonces. Es decir, era la que había. Hay que ubicarse en la época. Yo recuerdo, iba al almacén y me hacían un paquetito de porotos con un papel de estraza, hoy en día no existe eso.

NG: No sé si usted observó cuando compró o vendió libros de la Colección que muchos de ellos continúan cerrados...

JM: Sí, porque no todos interesan. Yo no voy a leer a Osvaldo Crispo Acosta, puedo leer Soledad perfectamente bien, puedo leer los Cuentos de [Horacio] Quiroga.

NG: Es algo que llama la atención, sucede hasta en las bibliotecas públicas.

JM: Claro, en su momento se distribuyó en todas las bibliotecas municipales y estatales. El fin era ese, llegar a todo el mundo. Y bueno, algunos títulos quizás para alguna gente eran más importantes que otros.

NG: En muchos de ellos, gran parte de la generación crítica estuvo metida en los prólogos.

JM: Toda la generación del ' 45 estaba metida en los prólogos, y sirvió para que [Benjamín] Nahum y [José Pedro] Barrán trabajaran en los prólogos de una cantidad de temas, y ahí después siguieron su tarea haciendo cosas mucho más importantes, quizás gracias a eso...

NG: ¿Piensa que pudo tener alguna intencionalidad política por parte de Pivel Devoto el sacar algunos textos en la Colección?

JM: No creo, era una persona muy especial. Ahí está [Carlos] Real de Azúa, blancos, colorados, están todos. Yo creo que en ese sentido el «viejo» era muy particular, muy neutro. Hizo la Historia del Uruguay y la Historia de los partidos políticos desde lo neutro, no era tendencioso. Publicó lo mejor que había hasta ese momento. No sé cuál era el plan que tenía, sé que había uno.

NG: Usted tuvo contacto con la biblioteca de Pivel Devoto, ¿qué recuerda de ella, tenía todos los Clásicos?

JM: Si los tenía todos. Incluso había más de una. Una la mandé al liceo de Paysandú «Juan E. Pivel Devoto», la colección de Clásicos Uruguayos y de la Revista Histórica. Esa fue una orden que me dio la sucesión.

NG: ¿Realizaba algún tipo de anotación en ellos? 
JM: Los tenía marcados con papelitos. Al viejo estilo, sin computadora, hacía notas en papel, y a su vez, las ponía en cajas. Cuando se le ocurría hacer un trabajo, lo ponía toda encima de una gran mesa, lo ordenaba, y en 24 o 48 horas te hacía un libro. Si hubiera manejado una computadora... sucede que para él era un invento del diablo. Apenas llegó a escribir en birome, escribía con lapicera fuente. Era gente de otra época, no es normal que actualmente exista una persona así. Con una gran memoria. Una vez, el tipo agarró un libro de León Bloy y me dice: «Ábralo». Lo abro y empieza a citar de memoria la primera página del texto. Es decir, recordó la foto de lo que había leído, y quién sabe cuánto tiempo hacía que lo había leído.

NG: Eso se puede vincular, a que estuvo emparentado a casi todos los emprendimientos culturales estatales durante esa época.

JM: Era a la cultura a lo que se dedicaba. Hay un montón de anécdotas en ese respecto. Una vez me trajeron unos documentos de Artigas, supuestamente, a lo cual, le mostré, lo abrió y dice: «No, es falso». Y claro, te llama la atención, cuando lo ves, decís: «No, ¿por qué?», y él te dice: «Mirá, ese día Artigas no estaba ahí», y ¿cómo se le puede quedar en la cabeza?, yo no me puedo acordar dónde estaba antes de ayer. Eran personajes fuera de serie, con una memoria increíble. Creo que dentro de cien años se van a acordar. Hoy en día, como no es marxista y no condice con la posición política de mucha gente... el tipo era un historiador. Hoy se antepone la parte política. Hizo mucho por el país, era un estadista. Era un tipo muy abierto, hay una anécdota cuando le quisieron hacer una entrevista: «¿Profesor qué opina sobre tal cosa?», y le dijo: «Mirá antes de preguntarme, estudio». Y tenía razón, qué va a perder el tiempo. Cuando le preguntaron antes de la apertura democrática, que vino el Rey de España, qué opinaba de los conocimientos que tenía el Rey sobre la historia del Uruguay, y les dijo: «Yo no le voy a tomar lecciones al Rey de España». Bueno quizás dentro de cincuenta años se den cuenta, lamentablemente no le sacaron el jugo que le tuvieron que haber sacado.

NG: ¿Cómo podría caracterizar su biblioteca?

JM: Era una biblioteca de una persona que le interesaba muchísimo la historia y la literatura. No te olvides que era la biblioteca de él y de la señora que tenía libros en inglés, alemán, francés, italiano. El archivo de papeles que juntó, correspondencia que compró, con gran sacrificio había comprado todo el archivo de [Juan Francisco] Giró, se formó un conjunto que se vendió al Estado y está en el AGNU. La biblioteca se donó al Partido Nacional, que lo puso en custodia de la Universidad de Montevideo. Él, hacia el año veinte comenzó a comprar libros, toda una vida comprando libros, le regalaban libros, documentos, papeles, y lo que formó en la Biblioteca del Museo Nacional fue algo muy importante. Yo no sé cuándo los leía. Lo peor de todo es que sí los leía, porque vos le hablabas y él te decía: «mire, en tal parte, y en tal caja del Archivo General de la Nación va a encontrar el documento que está buscando». 
NG: ¿Recuerda qué se leía a finales de los sesenta cuando usted comenzó a trabajar?

JM: Yo comencé a trabajar en la feria de Tristán Narvaja y se vendían muchos libros de filosofía, esotéricos, entre otros. Había mucho más público, había coleccionistas, ahora no los hay. Es una diferencia grande. Hoy en día tengo una primera edición de El pozo, y acá en Uruguay no la puedo vender. Antes estaban interesados por la pasión de tenerlos. Hay dos problemas, uno cultural y otro de plata. Los profesores hoy en día no están en condiciones de comprar libros. En aquél entonces vos veías que la gente tenía interés.

NG: Y existían varios tipos de publicaciones que alimentaban el consumo.

JM: Claro, vos tenías la Colección de Clásicos Uruguayos que era tan económica, que no podías decir que no. [...] Al ver la biblioteca de la gente de la época, observas que eran enormes, y ¿cómo hacían para conseguir todo eso? Tenían un acceso al libro quizás mejor al que hay en estos momentos. Me refiero, más que nada, a un libro de historia, una novelita hoy está en el entorno de los 200 pesos. Pero en aquel entonces, el libro de historia ya era otra cosa. Hay cosas que actualmente, por más que quieran, no se pueden hacer. Por ejemplo, el Gobierno del Cerrito de [Alejandro] Magariños Cervantes, hoy no se puede hacer. Son cosas que se pueden valorar en el futuro.

NG: ¿Cómo es el público actualmente?

JM: Yo creo que hay de todo. El lector por el libro en sí. El lector que puede leer en la pantalla de la computadora, o el lector que quiere tener el libro en la mano, organizarlo, anotarlo, son cosas diferentes. Hoy en Uruguay el nivel de tirada de libros es muy bajo (500 ejemplares para novelas, 250 para libros de historia) y con ello no se puede hacer nada. Los libros que se venden son la pavada, vos agarras un libro en serio, importante, no vendes más de 200 o 250 ejemplares. [...] Es difícil saber cuál es el mecanismo por el cual un artista llama interés al público. Un ejemplo es El pozo, [Juan Carlos] Onetti tardó mucho en vender su primera edición, y hoy en día estoy seguro que si sale de nuevo se vende. Quizás no se conocía, no tenía publicidad o el suficiente marketing.

NG: Ahí se ve la importancia de Marcha como publicación cultural.

JM: Sí, pero no te olvides de que Marcha era para determinada gente y no llegaba a todos lados. NG: Pero hoy en día no existe una publicación de ese nivel.

JM: No, no hay. Tampoco hay gente que lo haga. No tenés un Angel Rama, [Emir] Rodríguez Monegal, [Carlos] Real de Azúa. ¿De dónde sacás gente así? Se dio un momento cultural. ¿Cómo se dio todo junto en un mismo momento? Es difícil de explicar.

NG: Actualmente, ¿la Colección se vende? 
JM: Difícil porque mucha gente ya la tiene. ¿A dónde la voy a vender? ¿Instituciones? Es difícil encontrar un comprador para ellos. Una institución del exterior difícil que no la tenga. En Israel y Alemania debe haber varias, en Estados Unidos hay montones.

NG: Lo interesante es que, posteriormente, muchos de esos libros no tuvieron nuevas ediciones, salvo excepciones como podría ser Ismael de Eduardo Acevedo Díaz.

JM: Creo que salió Montevideo Antiguo, Artigas de [Carlos María] Ramírez, Quiroga y otros. Lo que es importante, en cambio, es el prólogo. Hay que informarle a la gente, si querés leer un buen prólogo, o si querés leer un texto crítico sobre [José Enrique] Rodó o sobre otros, en la Colección lo tenés.

NG: Entonces, ¿usted destaca el valor del prólogo?

JM: Yo destaco el valor de la obra. No tiene faltas. ¿Qué libro de hoy en día sale de la imprenta sin errores? Eso se hizo sin computadora. Yo creo que dentro de cincuenta años alguien va a decir: «Pá, lo que se hizo». Hoy en día, ¿por qué no se hace nada parecido?

\section{Entrevista a Wilfredo Penco ${ }^{309}$}

Wilfredo Penco es el actual director de Investigación y Publicación de la Colección de Clásicos Uruguayos, cargo honorario que se encontraba vacante desde que lo dejara Juan E. Pivel Devoto.

Es Doctor en Derecho y Ciencias Sociales, pero también se lo conoce en su actividad como ensayista y crítico literario. Actualmente se desempeña como vice-presidente de la Corte Electoral, y en su despacho nos recibió cordialmente.

NG: ¿Cuáles serían los orígenes de la Colección de Clásicos Uruguayos?

WP: Habría que buscar los antecedentes de la ley que crea la Biblioteca Artigas-Colección de Clásicos Uruguayos. Pivel Devoto ya era director del Museo Histórico hacía tiempo, pero en realidad, el que era el Ministerio de Instrucción Pública en esa época, la figura central del batllismo, era Zavala Muniz. Creo que él tuvo mucha importancia en el impulso. El primer tomo Artigas de Ramírez tiene un prólogo de Luis Bonavita, un historiador colorado que no creo que lo hubiera elegido Pivel y menos para prologar el primer título de un libro, que, además, es sobre Artigas. Entonces, en los primeros números de la Colección, creo que la influencia de Zavala Muniz debe haber sido importante. El propio hecho de haber ejercido el Ministerio de Instrucción Pública en un gobierno batllista, le da una jerarquía. Además, figura como presidente. Porque, ¿cómo se integra la Comisión editora? La preside el ministro, y después la integran las tres cabezas de las instituciones que se supone tienen vinculación directa con lo

\footnotetext{
${ }^{309}$ Entrevista realizada el 10 de julio de 2013.
} 
que sería una Biblioteca que lleve el nombre de Artigas. Ellos son: el director del MHN; el director del AGNU, que ya se había separado del museo, y el director de la Biblioteca Nacional. Son los tres directores, que a su vez son los tres repositorios de la historia documental del país. NG: Entre ellos van a trabajar en forma conjunta.

WP: Sí, exactamente, aunque esa es una concepción teórica. En la práctica, sobre todo cuando es ministro, el que le da el impulso a la Colección es Pivel, que cuando deja de ser ministro, es el ideólogo, y es el que lleva adelante la parte más de impulso.

NG: Durante el período en que Pivel Devoto es ministro, se sacan la mayoría de los tomos, cuando en los cincuenta salieron muy pocos. Ahora, también observamos que ese aumento coincide con el crecimiento en la venta de libros uruguayos en la década del sesenta.

WP: Eso es cierto, yo creo que está acompañando esa década del sesenta al fenómeno del boom literario en el Uruguay. La literatura uruguaya se vuelve a leer, o se lee por primera vez de un modo mucho más intenso, con la creación de las editoriales nacionales, la edición de autores nacionales, incluso ya en colecciones que impulsan las propias editoriales, la Feria del Libro, las páginas literarias más sistematizadas en los diarios. Aunque no necesariamente del hecho que afloren editoriales privadas, quiere decir que el Estado, que había tenido una política más sobria y lenta en materia de publicaciones oficiales, se lanzara de ese modo. La explicación, entonces, no es que surgieron editoriales privadas nacionales y eso estimuló la producción estatal. Quien promueve, quien incentiva, es fundamentalmente la figura de Pivel. Es, además, el que arma la Colección, es el que piensa en los títulos, en los prologuistas. Porque también la Colección está concebida de ese modo. Yo en algún momento lo conversé con Pivel, sin yo tener idea de que algún día iba a dirigirla. Y él justamente me decía, que la idea era que fuera una edición muy popular, con altos tirajes que hoy serían impensables. La idea de tirajes importantes era para una difusión masiva, siempre pensando en las escuelas, liceos, bibliotecas. Son libros que tienen que tener ese destino, además de la difusión en lugares habituales de comercialización. Pero piensa también desde el punto de vista formal en una edición muy sobria, está caracterizada desde la portada, pero con un prólogo muy importante. Los prólogos están integrados como un valor agregado fundamental que caracteriza a la Colección. Uno puede encontrar Motivos de Proteo o Ismael, en muchas otras ediciones, pero solo en Clásicos uno va a encontrar los prólogos de [Carlos] Real de Azúa, [Emir] Rodríguez Monegal, [Roberto] Ibáñez. Son muy importantes, no solo porque revelan una lectura de su tiempo de esa obra, que en muchos casos, tratándose de autores que habían producido setenta años antes, la lectura que esos prólogos proponen son lecturas nuevas, lecturas contemporáneas a la edición, sino también porque son prólogos muy cuidados en cuanto al repaso del texto y del autor que se estaba considerando. Eso, complementado con los otros dos elementos paratextuales, que 
son la síntesis biobibliográficas de cada autor, y los criterios de edición. Es muy probable, que Pivel haya tomado como referencias algunas colecciones en otros países latinoamericanos como Colombia, Venezuela, incluso Argentina y Chile. Pero esas características que de algún modo individualizan a la Colección, son propias de Clásicos Uruguayos. También, es muy interesante, que ese modelo, aunque no calcado, varios años después fue tomado por la Biblioteca Ayacucho en Venezuela impulsada por Angel Rama, que fue de los que trabajó con Pivel en la Colección. Existe otra característica, que es el cuidado de la edición, uno ve los nombres de los que figuran como responsables de su cuidado y se encuentra a [José Pedro] Barrán, Rama y otras figuras muy relevantes en su época.

NG: ¿Cómo hacía Pivel Devoto la selección de los autores?

WP: Creo que salvo algunas excepciones, solo publicaba autores fallecidos. La excepción es [Francisco] Espínola, [Carlos] Vaz Ferreira, más adelante, [Adolfo] Montiel Ballesteros, [Pedro] Ipuche, [Fernán] Silva Valdez. Salvo Espínola, pero tanto Silva Valdez como Ipuche, son figuras ya consagradas que habían conseguido premios nacionales de literatura, y que ya estaban en su crepúsculo. No estaban muertos cuando publicaron sus ediciones pero estaban finalizando sus vidas. Ese es uno de los criterios que aplicaba Pivel. También, en lo literario, agrega figuras indiscutibles porque también son parte de toda una generación que caracteriza la literatura uruguaya en determinado momento como es la generación del Novecientos, [Horacio] Quiroga, [Carlos] Reyles, Delmira [Agustini], Julio Herrera [y Reissig], Florencio Sánchez, [José Enrique] Rodó, todas esas figuras están incorporadas. Aunque, curiosamente, un nombre que se repite más, ya que además tiene una producción basta, es Reyles, mucho más que Quiroga. Por ejemplo, hay una selección de sus cuentos en dos tomos, e Historia de un amor turbio, pero son los títulos que agotan a Quiroga en Clásicos. [Eduardo] Acevedo Díaz, ni que hablar, prácticamente en forma completa. [Juan] Zorrilla [de San Martín], es también un autor que es publicado en forma reiterada. Eso da también una idea de una concepción de lo que se entendía como figura representativa de un momento del país, mirado siempre en forma retrospectiva. Si uno ve la obra de Ipuche o de Silva Valdez, son figuras que se les publica en los años setenta, pero en realidad es una obra de los años veinte, cuando el criollismo o el nativismo entran en auge. Desfilaron, además, unas cuantas figuras del ' 45 entre los prologuistas, pero el que más perdura es [Arturo Sergio] Visca, también con una concepción muy definida sobre la literatura uruguaya. Por supuesto, Rodríguez Monegal que también prologa, pero lo hace a Quiroga, Acevedo Díaz, Real de Azúa a Rodó, pero son casos más aislados, y casi referidos a autores concretos. Mientras que Visca publica el famoso tomo, hoy muy polémico, llamado Antología de poetas modernistas menores, que es una visión de él sobre la generación del Novecientos, con 
un punto de vista aparentemente menor, aunque pone a Roberto de las Carreras, que años después es reivindicado como una figura muy importante. La Colección refleja una concepción de la literatura al estado de situación de esos años.

NG: También sucede con la historia

WP: También, hay un evidente peso de la figura de Pivel en la publicación de la obra de [Francisco] Bauzá, que es su historiador modelo.

NG: Además le publica un tomo y medio de prólogo siendo el más extenso de toda la obra. Pero, ¿había una idea de extensión?

WP: No, si uno nota hay un promedio, pero hay excepciones como la de Pivel. La Colección es una convergencia de personas que se suman para construir una lectura colectiva, justamente desde los prólogos.

NG: ¿Se piensa hacer alguna reedición?

WP: Sí, la idea es volver a editar algunos tomos agotados, pero con un nuevo prólogo, manteniendo el prólogo inicial, para ver una nueva lectura, porque en el caso de los primeros han pasado sesenta años. Manteniendo el prólogo inicial porque ya están incorporados al volumen. Pero no es tan sencillo encontrar prologuistas que hagan una nueva lectura sobre el autor y que quedan enfrentados al prólogo anterior. Esa es una cierta dificultad que se encuentra. Todavía no lo hemos hecho, pero mi idea es volver a hacerlo.

NG: Podemos observar que la calidad de la obra de los nuevos tomos es muy distinta respecto a los que salían en los primeros años.

WP: Las técnicas son otras y los tirajes son menores, estamos en unos 700 ejemplares. Hoy no se justifican los mismos de antes. Lo que he querido mantener son las características físicas, ya que hubo un determinado momento, después de la muerte de Pivel y antes de que yo asumiera la dirección, de cierta modernización en la tapa, que es una concepción distinta, pero que le quitaba un rasgo de identidad física. Aún cuando a mucha gente no le pueda resultar estéticamente muy atractivo, de todas maneras es la característica de la Colección que vale la pena mantener.

NG: ¿Y la selección será igual a la que se hacía en tiempos de Pivel Devoto?

WP: Sí, en principio he mantenido que se hayan muerto. Segundo, tengo una lista manuscrita por el propio Pivel de autores que él tenía idea de sacar310, que estoy tratando de incorporar, también estoy en lo que es lo literario de actualizar, porque la Colección se acababa un poco con los autores del treinta. Ahora he incorporado a casi toda la generación del '45, ya no como prologuistas sino como autores. Incorporé a un autor que no podía estar fuera de la Colección

\footnotetext{
${ }^{310}$ Uno de ellos es Páginas sueltas de Juan Lindolfo Cuestas en tres tomos a principios del siglo XX, según lo que más adelante el entrevistado adelantará off the record.
} 
que es [Juan Carlos] Onetti, con La vida breve. Ahora voy a editar a Felisberto [Hernández] que es una figura que ha adquirido en los últimos años una dimensión que una Colección de Clásicos Uruguayos no puede prescindir.

NG: ¿La Colección tiene que tomar en cuenta en que está la crítica literaria?

WP: Sí, en cierto modo, hay que recoger los consensos críticos, o de la propia sociedad expresada a través de otro tipo de reconocimientos, como el interés de los lectores. También, hay que seguir rescatando autores olvidados. Hay en algunos, casos donde la Colección fue la que canonizó.

NG: ¿Usted reconoce que se está construyendo el canon de obras clásicas por parte del Estado? WP: Sí, eso por un lado, pero por otro porque es también el Estado el que está en condiciones de publicar o de reeditar. José Pedro Díaz, [Carlos] Martínez Moreno, no son reeditados en las editoriales nacionales y menos en las internacionales, son autores que el Estado tiene que editar, además de canonizarlos en cierto modo, recogiendo lo que es un consenso crítico lo que está dado en la lectura de los prólogos.

NG: A veces Pivel no solo seleccionaba, sino que según se recoge en los archivos, algunos legisladores le pedían publicar algunos tomos, como fue el caso de las Instrucciones del año XIII de Miranda.

WP: No puedo dar fe de ello porque no conozco ninguna situación en particular.

NG: Con relación a la fuerte figura directriz de Pivel Devoto, se nota una selección de los prólogos y prologuistas, llama la atención una carta donde le dice a Alberto Bula Píriz que no va a publicar su trabajo porque no coincidía con ciertos lineamientos que previamente le había comunicado sobre la obra de Delmira Agustini.

WP: Ahí puede ser que estuviera influido por el equipo que lo rodeaba, sobre todo en materia literaria, aunque él también tenía sus ideas sobre la literatura. En materia de historia la suya era la última palabra, pero en autores literarios, el caso de Bula fue una figura muy polémica. Aunque ahora está siendo un poco reivindicada, en los últimos trabajos de Aldo Mazzucchelli que justamente prologó la prosa inédita de Herrera y Reissig, reivindica bastante los trabajos de Bula, pero que en su momento fueron muy polémicos. Tuvo controversias públicas con Ibáñez, con [Alberto] Zum Felde. Entonces, si bien Pivel se lo debe haber encargado, la lectura que la habrá hecho él y algún otro asesor, aunque esto es una especulación, haya hecho de que le contestara de esa manera. Yo conocí bastante a Bula Píriz, y alguna vez él me contó esto.

NG: También aparecen trabajando en la Colección grandes autores que posteriormente desarrollaran sus trabajos, como fue el caso de José Pedro Barrán, Benjamín Nahum y Angel Rama. WP: Que eran funcionarios de la Biblioteca Nacional, además, Pivel logra armar equipos junto a ellos, luego de que se mete en la Biblioteca porque ahí funcionaba el Iniel, Instituto Nacional 
de Investigaciones y Estudios Literarios que dirigía Ibáñez. Cuando Ibáñez se va a Cuba a recibir el premio Casa de las Américas por un libro de poesía, Pivel que era el ministro, aunque ese era un cargo honorario, lo destituye, lo que genera una gran polémica con intervención parlamentaria donde hay un intento de interpelación a Pivel por parte de los socialistas, porque aparte Ibáñez era socialista, pero en definitiva interviene el Instituto. Y después termina formalmente incorporado a la estructura de la Biblioteca Nacional y se convierte en el actual Departamento de Investigaciones Literarias. Y cuando interviene se relaciona con toda la gente que estaba trabajando allí, entre ellos los mencionados.

NG: Respecto a la posición política de Pivel Devoto, ¿se puede ver un intento de darle cierto color político, o quizás como hizo con su trabajo de historiador, trató de balancear la Colección? WP: Él balanceaba bastante, era lo que le daba confianza porque cuando a él lo nombran director del Museo, lo nombra un gobierno colorado, y se mantiene a lo largo del tiempo también. Es cierto que había mucha influencia blanca, y que él provenía de una familia colorada vierista aunque él estaba reconocido como blanco. En general es muy respetado por esa búsqueda de todos los elementos más allá de las banderías que conforman la historia nacional. El sello de Pivel está muy marcado en el caso de Bauzá, que no es blanco ni colorado, o que es un tipo constitucionalista, más cercano a la divisa colorada desde el punto de vista católico, prebatllista. En definitiva, creo que logra ciertos equilibrios y ciertas ponderaciones dentro de la concepción que tiene sobre la historia y sobre la literatura. Y en años de dictadura, se publican ciertos títulos, pero ahí más influencia tuvo Visca.

NG: ¿Cómo definiría la Colección de Clásicos Uruguayos?

WP: La Colección de Clásicos Uruguayos es una construcción canónica de la literatura uruguaya concebida ampliamente, es decir incorporando también no solo a sus literatos sino también a sus historiadores, filósofos, geógrafos. Tiene el sello de quienes la impulsaron y al mismo tiempo, con una visión bastante plural en cada caso en particular, porque las lecturas van variando a medida que van cambiando sus prologuistas, que son figuras que en el momento en que se publican esas ediciones, tienen una voz autorizada para esas circunstancias. Son los que, además, escribían en la prensa y construían desde esos otros medios, más cercanos a la gente, como lo podían ser los medios periódicos. Es muy interesante porque amplía el abanico y no hace que la Colección sea una visión cerrada o acotada, sino que pluraliza las voces sobre todo en lo que es la lectura de esos autores. También, el aceptar ser prologuista de cierto autor, es una forma de adhesión a la selección de ese autor para la Colección. Creo que tiene una gran importancia sobre todo en los años sesenta cuando toma ese impulso y se instala con una familiaridad en las bibliotecas, o en las casas de los lectores uruguayos, y que pese a que en años 
posteriores pierde el ritmo y la intensidad de su número de ediciones, sigue cada vez que aparece un título, reivindicando esa idea inicial tan contundente en su momento.

NG: Entonces, ¿cumplió con su objetivo propuesto?

WP: Yo creo que sí, y lo cumplió ampliamente. Porque, además, son ediciones a las que se recurre como un elemento de referencia, no solo por el texto, sino por la lectura que sobre ese texto se propone en la Colección.

\section{Entrevista a Guillermo Vázquez Franco ${ }^{311}$}

Guillermo Vázquez Franco nació en 1924, y lejos de estar retirado, es uno de los historiadores más polémicos en lo que refiere a la posición nacional uruguaya que se quiso tejer desde los tiempos de Artigas. Profesor de historia de profesión, escribió primeramente para el semanario Marcha publicando algunos artículos históricos y posteriormente produjo varios libros de historia.

En su casa, repleta de libros, entre ellos muchos ejemplares de la Colección de Clásicos Uruguayos, aceptó concedernos una entrevista.

NG: ¿Cómo comienza a trabajar en Marcha?

VF: Yo comencé a trabajar en Marcha porque era profesor en el IUDE, que era un instituto privado de enseñanza que dictaba clases de preparatorios. Un estudiante, egresa de allí, ingresa a la facultad de Derecho y se hace cargo de la directiva de la sociedad de estudiantes, dentro de la división biblioteca y saca un folleto llamado Jus, de vieja tradición dentro de los estudiantes, y me pide un artículo sobre Artigas, yo se lo hice. Al año siguiente, otro alumno mío, Quijano, hijo del director de Marcha, dice: «Mi padre en la mesa conversaba sobre un artículo suyo que vio en Jus, y yo le dije que era profesor mío y quiere conocerlo». Por lo tanto, fui a conocer a Carlos Quijano, y me invitó a escribir en Marcha, y naturalmente comencé a hacerlo. Recuerdo que me dijo: «Nosotros pagamos las colaboraciones». Yo no le había dicho nada, pero si las pagaban mejor (risas). Llegué a figurar en el cuadro de colaboradores que tenía Marcha al pie. Aunque me costó caro, porque cuando vino la dictadura saltó que yo había colaborado en el semanario. Por un artículo que publiqué, desfavorable sobre [Washington] Reyes Abadie, donde le cuestionaba algunas interpretaciones sobre Artigas, Quijano me encontró en la redacción de Marcha y me dijo: «discrepo con su artículo, se lo voy a contestar», a lo que le manifesté que iba a ser un honor, ¡qué más quería yo que me contestara Quijano! En definitiva, no me contestó y me sacó de los cuadros de colaboradores de Marcha.

NG: Durante los años cincuenta y sesenta, ¿como recuerda el ambiente intelectual?

\footnotetext{
${ }^{311}$ Entrevista realizada el 12 de julio de 2013.
} 
VF: No lo recuerdo muy bien, yo no tengo muy buena opinión. Ni que tuviéramos una gran enseñanza. Fíjese, yo por mi apellido soy uno de los últimos en lista, y en tercero de liceo nocturno yo tenía el número 54 y en cuarto tenía el 59. Teníamos salones muy nutridos en gente. En preparatorios algunas de las materias se tenían que dar en el salón de actos del IAVA, como literatura dictada por [Roberto] Ibáñez, porque éramos alrededor de 180 en lista, y presentes o actuantes en torno de los 120 . O sea, eran conferencias lo que daba Ibáñez, ¿qué se puede esperar de una enseñanza donde casi no había contacto entre docentes y alumnos?

NG: Mucho de esos profesores que integraban el cuadro del IAVA integraron la generación de 1945, de alguna manera allí también se gestó.

VF: Sí, como Ibáñez, también estaba [Emir] Rodríguez Monegal, [Alejandro] Peñasco, [Manuel] Claps, [Angel] Rama.

NG: Y esas personas también trabajaban en Marcha.

VF: Sí, había una especie de régimen incestuoso. Yo te leo, vos léeme, yo te cito, cítame. No era explícito, pero...

NG: ¿Usted reconoce alguna influencia de ellos sobre el estudiantado?

VF: No.

NG: ¿La forma de pensar que tenían los estudiantes estaba muy separada respecto a los docentes?

VF: Tampoco me animo a decirle eso. Había terminado la guerra mundial, y había rispideces. Entre comunistas y anarquistas más que nada.

NG: Ahora, ya en el sesenta llama la atención el radicalismo de la intelectualidad.

VF: -Claro, pero allí está la revolución cubana.

NG: ¿Pero es solo la revolución cubana o también todo el trabajo intelectual de la generación crítica que formó a sus estudiantes?

VF: Puede ser, no lo he pensado. Puede ser que la revolución cubana haya sido el click. No había una prensa de izquierda, salvo El Sol que era muy endogámico. Pero la revolución cubana marca un antes y un después, así lo veo yo. Quizás, había pasiones contenidas en aquellos años cuarenta, había un anticomunismo muy beligerante, belicoso, sobre todo por parte del diario $E l$ Día.

NG: La publicación que marca toda la evolución desde 1939 hasta 1974 es Marcha.

VF: Marcha es un cordón umbilical. Marcha me ayudó a no estar de acuerdo. Aprendí a usar mi cabeza. Otro que me enseñó también fue Justino Jiménez de Aréchaga, profesor mío de derecho constitucional. Los análisis que hizo de la Constitución, nos enseñaban a diseccionar. Tierra y derecho en la rebelión oriental, es un libro donde apliqué la metodología que aprendí con él. Todavía hoy la sigo utilizando. 
NG: Esa generación está inmersa en sus prólogos dentro de la Colección de Clásicos Uruguayos, ¿qué era y es la Colección según usted?

VF: Sí, van a participar muchos de la generación del '45, pero también del '54, no porque fueran de ese año, sino que es 45 dado vuelta. Está [Raúl] Montero Bustamante, Ariosto González, entre otros. Ellos son el anti 45. Esa Colección en definitiva es Pivel Devoto. Él va a convocar a muchos integrantes de dicha generación pero con restricciones, filtros. Fíjese que no está publicado absolutamente nada de Eduardo Acevedo, y él es un pensador y científico medular en la cultura del país. Cuando usted está pensando en esta Colección, este silencio es también un testimonio.

NG: ¿Cree usted que Pivel Devoto fue importante para la selección que se realizó?

VF: Era el káiser. Sin Pivel no pasaba nada y con Pivel pasaba todo.

NG: ¿Cree que le imprimió una importa política, o intentó balancear la selección?

VF: Él trataba de balancear. Vamos a darle entrada a los colorados también, pero ¿a qué colorados? Gente de militancia notoria, no recuerdo que haya escrito. No es una colección de los blancos, tal vez no es de ninguno. Yo creo que estuvo bien administrada.

NG: ¿Cuál cree que podría ser la idea de Pivel Devoto en la selección?

VF: De Pivel sentí una definición que decía que era el historiador del Estado. La idea era mostrar al Estado autores de un calibre muy amplio a través de mucho tiempo. Es una colección muy rica.

NG: A usted, en su trabajo como historiador ¿le ha servido?

VF: Sí, me ha servido y me sigue sirviendo. Es una de mis fuentes, junto con la Revista Histórica. Es innegable. Además, rescató material que si no fuera por él, yo no lo tendría, por ejemplo a [Juan] de la Sota, [Alejandro] Magariños Cervantes, a su hermano Mateo. Estoy muy satisfecho. En cambio, [Francisco] Berra no está.

NG: Pero está la polémica que mantuvo con Carlos María Ramírez.

VF: Sí, pero el Bosquejo histórico no está.

NG: ¿Allí estaba la mirada artiguista de Pivel Devoto?

VF: No cabe duda. No tengo la prueba, pero si la convicción.

NG: ¿No se observa también un nacionalismo cultural?

VF: Sí, es un nacionalismo que tiene la doctrina Pivel. De un documento que no hable bien de los próceres que hicieron a la patria y a los partidos, si conozco uno de ellos no lo doy. Además, a partir de no dar un documento, el paso siguiente es lo oculto, y el siguiente es lo destruyo. Eso va en contra de lo que es nuestra disciplina. Es la esencia. Si usted intercala sus amores y odios, entonces no está haciendo historia. Está haciendo una apología.

NG: Pivel Devoto ¿era un historiador o un apologista? 
VF: Yo creo que era un apologista. La revolución oriental fue democrática y popular, la de Buenos Aires fue aristocrática y de una minoría de patricios. O sea, acá están los buenos, y acá los malos. Era un maniqueo. Y además, era un porteñofobo que inoculaba porteñofobia. Muy delicadamente, pero lo hacía. En los Clásicos se nota, dentro del energúmeno de [Francisco] Bauzá, en el embustero de Pablo Blanco Acevedo. Que tienen sus preciosos tomos en la Colección de Clásicos Uruguayos.

NG: Actualmente ¿le reconoce un peso cultural?

VF: -Creo que sí. Lo observo en gente del ambiente historiográfico.

NG: Esa unanimidad historiográfica, ¿fue solo un trabajo de Pivel Devoto?

VF: No solo Pivel, porque él también tiene un caudal detrás. Bauzá, Felipe Ferreiro, [Juan Antonio] Rebella, Héctor Miranda, están detrás de él, o sea, viene recogiendo una cosecha que viene sembrada de antes. Además, tiene una enorme influencia cultural y política. Ejerció en el Instituto de Profesores y formó a muchas generaciones. Era un tipo cautivante, seductor. A mí me sedujo. Era un encanto. Era ministro de Instrucción Pública, director del Museo, del Archivo, sacaba la Revista Histórica, los Clásicos, era profesor del IPA, y me lo cruzo sorpresivamente en Sarandí e Ituzaingó. Había un café llamado Pedemonte, y ese hombre que era todo eso me dice. «Vamos a tomar un copetín y seguimos charlando». Yo estaba apurado, pero ¿cómo le decía que no? Entonces fui a tomar con él y a hablar. Además era un tipo que podía tenerlo en una carcajada permanente de diez, doce, quince minutos, y había que decirle: «Pare Pivel, me duele el diafragma de reírme». Cada una de sus cosas venía con una erudición militada. Le daba el autor, la obra, el pie de imprenta, el año. Era apabullante, cuando hablaba Pivel ¿quién le iba a decir «callesé que ahora voy a hablar yo»? Pivel arrugaba a cualquiera. [Wilson] Ferreira Aldunate, le tenía mucho respeto.

NG: Hoy en día, la visión que se tiene sobre él es distinta, no de tanta admiración.

VF: -Sí, le han bajado los decibeles.

NG: ¿Eso es porque ya está muerto, y es más sencillo hacerle frente, o porque existe una renovación historiográfica?

VF: Creo que es porque ya murió, porque la historiografía acá no se renueva. Porque si sucede eso, sería dramático. Tendríamos que aceptar que estamos parados sobre una estafa. Entonces, a nadie le gusta que su país sea una estafa.

NG: ¿Cree quizás que la Colección intentó justificar culturalmente el nacionalismo estatal?

VF: Tal cual usted lo ha dicho. La Colección al servicio de una idea. 


\section{entrevista a Juan Pablo Pivel}

Juan Pablo Pivel Ranieri es uno de los dos hijos de Pivel Devoto. Es bioquímico de profesión y vive en Madrid desde los años setenta. Esta entrevista fue realizada entre los días 15 y 17 de noviembre de 2020.

NG: ¿Cuáles son los orígenes filiares de su padre?

JPP: El apellido Pivel es un viejo apellido francés de la zona de Lorena. De modo que cuando dicen Pivel de origen vasco eso se lo inventó él. En el fondo porque su origen le importaba un carajo. Durante la guerra Franco-Prusiana, mi bisabuelo Joseph Pivel Creux ${ }^{312}$ seguramente soldado derrotado, huyó a París, porque los soldados atacaron la comuna de París bajo órdenes de Napoleón III. Es perseguido judicialmente. Era ingeniero. De modo que mi bisabuelo se llamaba Pivel Creux, Creux es un apellido Breton. Hay algunos Creux de la nobleza lituana. Se casó en Euskadi, seguramente, con una señora de apellido Berjot cuyo segundo apellido no me acuerdo, pero es seguro que ese segundo apellido de mi bisabuela fuera vasco. Se embarcaron huyendo y se instalaron en Buenos Aires. Y de allí nació mi abuelo, Juan Pivel Bertoj, que nació en Buenos Aires, yo creo que nació en el barco. Y luego emigran para el Uruguay, para arriba, Salto, Paysandú, Montevideo. Y por el lado materno, Devoto Cibila era mi abuela que era pianista. Un hermano de ella fue tenor en Salto. Fue el primero que cantó Tosca de Puccini en Uruguay. Son apellidos típicos ligures ${ }^{313}$. Los Devoto son de un pueblecillo de la Liguria que se llama Chiavari, un pequeño puertecillo que está cerca de Génova. De modo que entre genovés y de Lorena, por ahí están los antepasados reales de mi padre.

NG: Quizá la foto más conocida de Pivel sea la que está parado con traje negro y una mano sobre la mesa, ¿dónde se encuentra?, ¿es su casa o un escritorio de trabajo? No encontré nunca referencias, ni siquiera quién pudo haber tomado la foto.

JPP: No estoy seguro esa foto donde es. Él está de pie, yo creo que es en mi casa. Hay un mublecillo que está en la entrada que es ese. Creo que es en mi casa.

NG: ¿Cómo podría definir a su padre en términos personales, intelectuales y políticos?

JPP: Mi padre, si lo tuviera que definir con una palabra, visto desde afuera, diría que es una persona contradictoria. Muy contradictoria. En términos personales, era una persona muy activa, muy marcada por la temprana muerte de su padre. Cuando dio a luz a su hermano menor

\footnotetext{
${ }^{312}$ Originalmente este antepasado de Pivel es a su vez hijo de Nicolas Pivel y Julie Sophie Creux. Nicolas es de Polaincourt, Francia.

${ }^{313}$ De la región italiana de Liguria.
} 
Ulises que nació en 1923. Era Ulises una persona más suelta para hacer Pivel, que son más secos que el desierto. Pero intelectualmente y políticamente muy mediocre. Llegó a ser presidente de la cámara de Diputados, quizá por eso.

Mi padre era contradictorio personalmente porque era una persona con gran afectividad, pero con una muy particular incapacidad para demostrarla, sin embargo, era más afectivo fuera de casa que dentro de casa. Era más afectivo con los hijos de un amigo o de una amiga que conmigo. No son celos, no digo que no fuera afectivo, pero era más expresivo cuando no tenía un compromiso de tipo pater familiae. Desde el punto de vista intelectual, quizá era el punto en que fuera menos conflictivo, porque desde el punto de vista intelectual yo creo que está muy bien retratado en el reportaje que le hizo Alicia Vidaurreta. Mi padre rompió los moldes de una historia liberal, mitrista, siguiendo la estela de Luis Alberto de Herrera y del revisionismo histórico, que en Uruguay fue bastante más que en Argentina. En Argentina tuvo personajes patéticos como Jorge Abelardo Ramos o Jaureche. No sabría cuál es el equivalente a Pivel y a Herrera en Argentina.

Lamento haber perdido un libro de la historia de Argentina escrito por un historiador de Santa Fe, de apellido Busaniche ${ }^{314}$, la historia más equilibrada. Pues Pivel no era nada contradictorio en la historia, desde el punto de vista de que se volcó a rescatar toda la documentación que había en el país, cuando hablo de documentación me refiero a papel. También se dedicó a rescatar todo lo rescatable desde el punto de vista arquitectónico o artístico. Como ministro dio apoyo a las letras, a las artes. La lista de casas que adquirió el MHN es enorme y creo que cuando mi padre asumió, yo no había nacido, el museo tenía la casa de Rivera y Lavalleja y se acabó. En ese sentido era muy coherente.

La mayor coherencia está en dos cosas: mi padre nació y vivió bajo el Imperio de la cultura mitrista, liberal, colorada, batllista, sectaria, dominante, muy sectaria. Y del Colorado se pasó al rojo, rojo y Colorado eran lo mismo. El comunismo y el marxismo no puede negar su origen, parte de su origen en la Ilustración, en el liberalismo, en el peor liberalismo. El liberalismo del siglo XIX, el de la Defensa de Montevideo, el de los ríos abiertos para que entraran las naves hasta Paraguay. El liberalismo del modelo único, que no tiene nada que ver con el liberalismo moderno de Hayek o de Isaiah Berlin o de Hannah Arendt, por citar algunos. Mi padre rompió todos los moldes, hay un historiador que para mi gusto es patético que se llama Torres Wilson ${ }^{315}$, que creo era del Partido Nacional. Yo aclaro que no soy del Partido Nacional, yo soy blanco que no es lo mismo. Se lo dije a Cuqui Lacalle ${ }^{316}$ en casa. Porque él me dijo: vos sos más del

\footnotetext{
${ }^{314}$ Muy probablemente José Luis Busaniche (1892-1959) integrante del revisionismo histórico argentino.

${ }^{315}$ José de Torres Wilson (1931-1999) fue docente e historiador, se hizo cargo del MHN en el período 1992-1997.

${ }^{316}$ Hace referencia al ex presidente Luis Alberto Lacalle Herrera que se hizo cargo del Poder Ejecutivo entre
} 
Partido Nacional que yo, Y yo le dije: No Cuqui, yo sí soy algo soy blanco pero el Partido Nacional creo que no. Esta es una anécdota, usted sabe que la relación entre mi familia y la de Luis Alberto de Herrera ${ }^{317}$ fue muy íntima, muy cercana. Aparte yo fui compañero del liceo y bachillerato con Cuqui padre, obviamente.

Mi padre se pasó por el forro de la nariz las ideologías. Hizo una historia limpia basada en datos. Torres Wilson lo califica de historiógrafo, es decir, el historiador para este señor y para los marxistas, para los que llevaban Marcha debajo del sobaco todas las semanas hasta que les destiñera. Esa historia ideologizada, sea mitrista o sea marxista, esos eran historiadores, los que contaban los hechos, esos eran historiógrafos. Pivel rompió con eso completamente, e hizo de la historia una revolución cultural. En la historia uruguaya que escribo muy pocos la han seguido fielmente. La famosa pareja de Nahum y Barrán, quizá más Barrán, no lo sé, hace años que no los leo. Conocí poco a Nahum, a Barrán lo conocí bastante, era una persona muy entrañable. El dato, la búsqueda del dato, no decir nada que no estuviera fundamentado, eso me parece muy importante. Entonces yo distingo, en ese sentido, las dos historias: la historia con mayúscula es la historia ideológica, la estrella que va unida a una interpretación, o mejor dicho la historia de que los hechos hay que encajarlos en una interpretación aunque sean redondos y la interpretación cuadrada. La historia con minúscula es contar lo que pasó, crudamente, el hecho, el dato pelado. Y a veces, no transcurre un tiempo suficiente para hacer un análisis, y mucho menos el análisis del pasado en un solo molde, en ese sentido Pivel era muy ecléctico. Por ejemplo, Pivel no era enemigo de la empresa privada pero era estatista. Era blanco, pero era partidario de una economía estatizada. Era partidario de las empresas públicas, le ofrecieron muchas veces ir a la empresa privada, por su capacidad de gestión, siempre dijo que no, adoraba lo público, el Estado. Como lo puede adorar un republicano francés. De hecho, ahí hay otra contradicción sobre los orígenes étnicos de mi padre. En ese sentido era más batllista que otra cosa, pero nunca despreció la iniciativa privada, ni consideraba al empresario un delincuente, no tenía prejuicios en lo absoluto. También en el aspecto religioso, mi padre no era católico para nada. No era católico ni de ninguna religión. Lo que pasa es que respetaba, tenía un aspecto conservador, respetaba lo instituido, la Iglesia Católica con su valor de, que yo no comparto obviamente, con su valor de horma de la sociedad. Respetaba la jerarquía católica. De hecho, cuando él fue consejal o ministro fue la primera vez que los estudiantes de colegios católicos pudieron subir gratis a los autobuses.

En términos políticos, también contradicciones. ¿Un estatista blanco? Yo entiendo que una persona pueda ser estatista para la salud púbica pero no para vender whisky. El Espinillar me

1990 y 1995. Su hijo, Luis Alberto Lacalle Pou, es el actual presidente del Uruguay.

${ }^{317}$ Herrera era el abuelo de Lacalle. 
parece un disparate. ${ }^{318}$ Que los servicios públicos del transporte municipal tengan que ser del ayundamiento, ¿por qué? Que tenga que haber una línea aérea de bandera, que por las vías de un país no puedan circular trenes operados por otras empresas, pero de la telefonía móvil sí. ¿Entonces la telefonía móvil es de derechas y los trenes son de izquierdas? Es todo una gran masturbación mental. Y en ese sentido mi padre era contradictorio porque era estatista pero respetaba la actividad privada. Evidentemente, si mi padre hubiera entendido, porque no era muy adepto a buscar esquemas filosóficos, yo creo que el filosofo de mi padre sería David Hume. La negación de la causalidad, me parece que es lo que guía..., aunque creo que no se daba cuenta, era en ese sentido muy creador y no se llevaba por guías de otros. Le salió así, le salió una historia libre. Esa es la palabra. Yo que soy antiestatista, por mí los países deberían funcionar como sociedades anónimas, patrióticas pero sociedades anónimas con un gerente.

Quiero dar un ejemplo que para mi es fantástico. Es una película que no sé si es de Scorsese o Tarantino. En cuyas películas de mafiosos siempre se vierte sangre más que en la Guerra de Corea. La historia es que hay tres mafiosos, uno de edad media, uno joven y uno viejo que van a cenar a la casa de la mamma de uno de ellos. Con la cual los tres mafiosos, el hijo y los amigos del hijo son súper cariñosos. Y la vieja les había preparado unos macarrones a la boloñesa. Y los mafiosos se comen los spaguettis o los tallarines, no sé que eran, y luego de un determinado momento salen a la calle. El de edad media era el hijo de la vieja y salen los dos, el viejo y el joven. El viejo era Donna Meche, que hizo de galán en los años treinta y cuarenta, con poco éxito y después fue un buen actor viejo. Lo que no había contado de la película es que dentro del maletero del coche llevaban un cadáver que acababan de matar (sic). Cuando sale el viejo, el joven va aa fumarse un cigarrillo o a hablar mientras el del medio o de edad madura se despedía de la mamma, pues se ve que hay un enorme charco de sangre debajo de la matrícula posterior del coche. Entonces el joven se queda traumado porque no estaba muy fogueado en ver sangre fuera de las venas y le pregunta al viejo ¿por qué es que pasan estas cosas?, ¿qué está pasando?, y entonces el viejo lo mira con una cara como de lejanía y le dice: - Things happen. Es decir, las cosas suceden. Esa es la ideología histórica de Pivel Devoto.

NG: Historicista. Considero leyendo su obra que hay por lo menos dos etapas marcadas. Uno durante su juventud hasta los $40 \mathrm{y}$ la posterior. En esos primeros años de artículos hay estudios pioneros sobre las imprentas, además de historia diplomática y poca cosa de los partidos. Recién cuando asume en el MHN se posiciona como un historiador nacional y es allí donde arrancan sus libros de Historia nacional y de los partidos. Es más, hay una referencia en uno de esos

\footnotetext{
${ }^{318}$ Hace referencia a una bebida producida por la empresa estatal ANCAP (Administración Nacional de Combustibles, Alcohol y Pórtland). Sin embargo, el Espinillar es un ron, no un whisky como dice el entrevistado.
} 
primeros artículos donde habla de Berra y se lo pondera en parte positivamente, y posteriormente se lo machaca mayoritariamente con el libro de Bauzá en la mano. Y coincido que el libro de los bancos es francamente imprescindible. Pero hay que agregar todos los prólogos de la Colección de Clásicos Uruguayos, sobre todo el de Bauzá de 700 páginas...

JPP: Es cierto que sus primeros trabajos fueron diplomáticos. Él viajó a Río de Janeiro para estudiar la Misión de Nicolás Herrera, conste que yo no soy historiador, soy bioquímico. Quiero decir, yo soy un aficionado en esto. No me haga mucho caso en mis especulaciones teóricas. Es graciosa una foto de él bajando del barco con una cantidad de libros bajo el brazo, jovencito, con su bigotito chaplinesco, un señor muy delgado además. Yo creo que todo empieza con la Historia del Uruguay que escribió con mi madre y que editó Artagaveytia que era el marido de Emma su hermana. Después se separaron y Artagaveytia, pues no sé. El marido de Emma Pivel. Esa fue la primera edición, luego se editó en Medina en fascículos, algunos de ellos solo firmados por mi madre, creo recordar. La cosa es que efectivamente luego empieza la Historia de los Partidos Políticos que editó el Parlamento sin que viéramos un peso. Luego para mí, en otro nivel todo lo que publicó en el Archivo Artigas, los prólogos, Raíces Coloniales... que para mí es un libro esencial de la Historia del Uruguay, la Historia de los Bancos, y un libro poco conocido, pero muy importante, que escribió con mi madre, fueron los dos únicos libros que escribió con mi madre, que es la Historia de la Amnistía del Uruguay, hecho en plena dictadura militar, un señor libro. También escribió una reseña pequeña sobre Oribe. A mi el de Bauzá me gusta. No entiendo por qué eso que lo machaca. No lo veo tan claro. A mi me gustó y creo que ha captado la esencia de Berro ${ }^{319}$ que era un yanqui por decirlo así. Era un hombre con mucha historia norteamericana, con un gran posicionamiento en lo que es el poder municipal, que es esencial en el Partido Nacional, basta ver las intendencias que tiene y los gobiernos departamentales. También esa posición equilibrada de los autores entre el caudillismo y por supuesto, su posición, lo que provoca su caída, la Revolución Libertadora de Flores y Paysandú y la Guerra del Paraguay. Recordando que el canciller de Berro fue Juan José de Herrera, el padre de Luis Alberto, el abuelo del Cuqui, el bisabuelo del Cuquito.

En cuanto a la Historia de los Partidos... yo creo recordar que lamentablemente, excepto pocos partidos en el mundo, son leninistas. Cuando digo leninistas no digo que adoptan el marxismoleninismo pero sí adoptan la estructura de partidos políticos que definió Lenin para el Partido Comunista que es un núcleo central. Una institución central, que es el comité central, unas filiales muy centralizadas, que de hecho fueron los soviets, que en la práctica no deben haber sido, pero lo fueron de hecho, porque mataron a todos los que no eran comunistas, una estructura

\footnotetext{
${ }^{319}$ Se equivoca y cambia a Berra por Berro, lo que genera el error de personalidades políticas.
} 
de definición de línea política rígida, definida por congresos anuales, un órgano directivo centralizado denominado máximo órgano de congresos, llámese comité central, comité federal, comintern, etc, el mandato imperativo, las cuestiones de disciplina interna, la posibilidad de echar a un miembro por no cumplir las normas del partido, lógicamente el aporte económico. Echar del partido tiene distintas connotaciones, en Europa puede ser fundar otro, quedarse en casa leyendo el periódico. En el caso del comunismo implicaba un tiro en la nuca. La mayoría de los partidos occidentales siguen un perfil leninista, en Uruguay eso no sucedió tanto, excepto el batllismo. Donde como dijo un político español Alfonso Guerra "el que se mueve no sale en la foto". En el Partido Nacional hubo disidencias, fuera del lema inclusive lo de Carnelli ${ }^{320}$, la reconstrucción del lema con la $\mathrm{UBD}^{321}$, que nosotros le llamábamos en broma la iúbede ${ }^{322}$ porque eran pitucos, que los llevaban el $\mathrm{MPN}^{323}$ que era de origen herrerista. La unificación del partido pero siempre con una lasitud y una amplitud distinta a los partidos leninistas. Este es el comentario en general. Yo no soy capaz de analizar a ese detalle los libros sino ver la tendencia general, que se ve tanto en los prólogos como en la Revista Histórica, como en la cantidad de gente que formó para que pudiera leer los documentos. Hasta la definición de una caligrafía que se ve clarísima en los documentos del Archivo Artigas. Algunos alumnos y alumnas que tuvo muy importantes: Maria Julia Ardao, Elisa Silva Cazet en el Museo, Aurora Capillas de Castellanos. Lo fundamental es la ausencia del corset ideológico, la objetividad, el hecho, la importancia del hecho, y después cada cual que se lo lea como quiera. Los hechos de la Historia del Uruguay para mí son incontestables. Uruguay pasó del colorado al rojo, y de estar en rojo a ver como se hace un poco más rosado.

Sobre la Colección de Clásicos voy a tratar de recordar algunos títulos porque yo creo que es muy difícil hablar de clásicos uruguayos en un país que tiene muy pocos años. El concepto de lo clásico es el que habla, precisamente en un tomo de los clásicos, yo creo que está en dos tomos, Torres García ${ }^{324}$, lo clásico como modelo. No como antiguo sino como prototipo, como modelo. La cultura clásica es la que deja modelos estéticos o modelos de lo que sea. Entonces en un país tan pequeño es muy difícil discernir dónde está el límite entre lo clásico y entre lo que aún no se sabe, lo que va a ser clásico o no. Es lógico que no esté Onetti, que no esté Benedetti, en primer lugar porque es un cursi. El único que echo en falta, y se lo dije una vez,

\footnotetext{
${ }^{320}$ En referencia a Lorenzo Carnelli (1887-1960) que escindiera el Partido Nacional, entre 1925 y 1933, por diferencias ideológicas con Herrera (ver Frega y otros, 2008).

${ }^{321}$ La UBD (Unión Blanca Democrática) fue un sublema dentro del Partido Nacional contrario al Herrerismo. Fue creada en 1956 y logró acceder a la Intendencia de Montevideo en las elecciones de 1958, y a la jefatura del gobierno nacional en el segundo colegiado blanco (1963-1967).

${ }^{322}$ Pronunciación en francés (ver Frega y otros, 2008).

${ }^{323}$ El MPN (Movimiento Popular Nacionalista) fue creado en 1953 por Daniel Fernández Crespo y disputó dentro del Herrerismo las elecciones durante las décadas del cincuenta y sesenta (ver Frega y otros, 2008).

${ }^{324}$ Hace referencia a La recuperación del objeto, editados por la Colección... en 1965 (vols. 75-76).
} 
es Líber Falco. Falco para mí es un clásico y no está. Sin embargo, hay verdaderos hallazgos, puede sorprender que haya puesto en los clásicos la memoria de un general colorado que participó en la Guerra del Paraguay ${ }^{325}$, pero bueno es un clásico. Lauracha, Acevedo Díaz, las poetizas Ibarbourou, Delmira Agustini, María Eugenia Vaz Ferreira. No están otras posteriores como Ida Vitale o Idea Vilariño. Vitale fue Cervantes el año pasado. Los geógrafos, Reyes, eso sí es un clásico. Benjamín Fernández y Medina que es un tipo de cuento distinto donde aparece el mar, por ejemplo, que no aparece normalmente. Benjamín Fernández y Medina tiene cuentos hermosísimos sobre el mar. No aparece Espínola ${ }^{326}$, creo que no aparece Morosoli ${ }^{327}$, aparece Acuña de Figueroa. En fin, es muy interesante un análisis de quién aparece y quién no aparece y cuál es el concepto de clásicos uruguayos. También recuerdo la Colección de Clásicos Universales en la cual lo que más destaca es el gran tomazo del libro del inca Garcilaso. La tierra purpúrea y algo de cultura romana. Insisto, un análisis curioso es analizar qué es clásico uruguayo y si la colección está acertada en esos temas o no. Hay algún libro sobre el caudillismo, que es muy importante, sobre la discusión sobre el caudillismo. Me parece muy interesante analizar los títulos y decir quién era clásico, si estamos todos de acuerdo en quién es un clásico uruguayo y quién no es, y qué clásico faltaría.

NG: En función a la definición de clásico creo que tiene que ver con canon, como construcción de un canon nacional. Tratar de formar al ciudadano en términos culturales. Para eso es necesario leer los clásicos uruguayos. Hay un canon literario y uno historiográfico. Ese canon historiográfico es seleccionado por Pivel. En todos los libros de historiografía los prólogos son de Pivel, algo que llama la atención y es interesante, y en esa selección se establece quiénes son los historiadores más importantes. Faltaría uno, ese sería Pivel que más adelante sería editado por la Colección.... Uno de los que falta es Eduardo Acevedo con quien había tenido una enemistad como consecuencia del Archivo Artigas. Otro de los enfrentamientos que tuvo fue con Bula Píriz sobre el prólogo de Agustini. Quien se encargó posteriormente de ese prólogo fue Esther de Cáceres. ${ }^{328}$ Yo pensaba que había una relación fuerte con el catolicismo ya que dicha autora era una católica ferviente. En consecuencia, creo que la ausencia de Eduardo Acevedo es importante.

JPP: Lo de Eduardo Acevedo no tengo ni idea. Puede ser un tema de celos profesionales. Mi padre era muy joven. No lo sé. En cuanto al clásico como canon, claro, esa es la idea. El asunto qué es un canon uruguayo o nacional. ¿Cuál es el canon artístico? Aparece Figari, Torres García

\footnotetext{
${ }^{325}$ En referencia a Díaz, César (1968). Memorias. Vol. 129.

${ }^{326}$ Recién en el 2001 se publicará por la Colección... a Espínola, será Sombras sobre la tierra (vol. 175).

${ }^{327}$ Sin embargo, Morosoli y Espínola serán prologuistas de la Colección....

${ }^{328}$ Ver Capítulo 7.
} 
y no se si alguien más. En los poetas aparece, aparte de las tres poetas grandes, Julio Herrera y Reissig, Carlos Sabat Ercasty, En geografía, que es otro canon importante, aparece Larrañaga, Reyes. Y en cuanto a los prólogos él tenía un staff de gente afín. No veo demasiada afinidad con Esther de Cáceres, ella era muy amiga de mi madre, muy afín en temas religiosos, Ella estaba casada con el psiquiatra Alfredo Cáceres. Mi padre como católico nada, yo nunca lo vi en ningún acto católico, ni ninguna manifestación de fe.

NG: ¿Por qué se han negado a una nueva edición de la gran mayoría de sus obras? ¿Conoce si existe alguna obra inconclusa de su padre?

JPP: La reedición de libros de mi padre se hizo dos veces. Las dos veces la familia no cobró ni un duro. La primera del parlamento, en "homenaje" le editó una edición horrible de la Historia de los Partidos Políticos, horrorosa de fea. Fea, fea, fea. Y luego el Partido Nacional con nuestra anuencia reeditó, en ocasión de una fecha determinada, pero tarde porque no llegó a tiempo. Creo que era en el 2011 por la Batalla de las Piedras y se publicó como cuatro o cinco años después. En esa época fue cuando el Estado compró el archivo y nosotros donamos la biblioteca al Partido Nacional. Y se reeditó Raíces Coloniales... entera, facsímil. Se reeditó con tres prólogos, uno por Luis Alberto Heber (presidente del Directorio del PN en ese momento), otro de Rodolfo Rodríguez Rissoto ${ }^{329}$ que fuera la primera víctima uruguaya del virus chino de mierda éste ${ }^{330}$, muy amigo personal mío también, que ha escrito un libro sobre los indígenas del Uruguay que es magnífico, reivindicando lo guaraní uruguayo. Y luego un prólogo mío, y en ese prólogo digo lo que pienso sobre la historia ideologizada. Más que contradictorio mi padre era poliédrico, tenía muchas caras. Pero yo creo que ni él mismo sabía que las tenía. Era un tipo genial que creó una historia única, libre. Libre de toda atadura ideológica, circunstancial, política, y como muestra el último botón. Uno de los alumnos extranjeros predilectos fue Milton Vanger, el historiador del batllismo. Casado con una Oribe, ella se convirtió al judaísmo por él y se fue a los Estados Unidos. Murió hace pocos días Vanger ${ }^{331}$. Yo me acuerdo mucho de él. Fue el que escribió el famoso libro sobre Batlle que según dicen llegó a inspirar a Roosevelt, no me encajan las épocas. Cuando Vanger venía a mi casa ${ }^{332}$ Roosevelt ya había muerto, en 1945.

NG: ¿Y qué me dice de la biblioteca de su padre?, ¿cuál fue su derrotero?

JPP: La biblioteca era un caos. Estaba todo en mal estado. Recuerdo que en el escritorio de mi padre había una colección de Marcha, cuya parte inferior se había podrido. En la habitación de la parte trasera de la casa, una habitación que era un garage se había llenado de libros. Está casi

\footnotetext{
${ }^{329}$ Profesor de Historia en formación docente.

${ }^{330}$ En referencia al COVID 19.

${ }^{331}$ En realidad murió en Julio del 2018.

${ }^{332}$ Vanger había llegado a Uruguay en 1963, por lo tanto, lo que dice Pivel (h) es más que coherente.
} 
inaccesible, se llovía y había también podredumbre. Entonces para donar la biblioteca, para tomar la decisión de donar la biblioteca tuvimos que llegar a un acuerdo con Julio Moses de la librería Oriente y Occidente, que éramos amigos. Para que él se dedicara a ordenar y limpiar todo eso, la biblioteca de Historia Nacional y Americana, no la Universal que está en Ellauri ${ }^{333}$ todavía. Porque no interesaba. Libros que, por otra parte, pueden hacer mención a Uruguay pero pueden estar en cualquier lado. La única forma de pagarle a Moses su trabajo, porque él vivía prácticamente para ordenar 20 mil libros, fue seleccionar unos pocos libros, algunos raros evidentemente, y venderlos para sacar dinero para pagarle a él. Y también para ir refaccionando la casa porque se venía abajo. Es decir, la casa tenía una instalación eléctrica la cual no se incendió de casualidad. A medida que se iba limpiando y arreglando, se iba arreglando la electricidad. Moses muere con algunos libros sin vender, de cierto valor y que yo no pude recuperar. Lo pregunté con su viuda y ella no me supo decir donde estaban. Yo creo que los tenía en Buenos Aires, porque algunos libros me consta que fueron para Buenos Aires o Brasil. Es decir que no se vendió a Estados Unidos. Yo creo que se vendió a través de Buenos Aires algunas cosas. Y le estoy hablando a cifras que no llegan a diez mil dólares el total. Yo podía donar la biblioteca pero no pagar para que se limpiara. Yo vivo en Madrid, tengo mi familia aquí y bastante hacíamos, porque mi hermana nunca se metió. Mi padre pidió que la biblioteca, está en el reportaje de Vidaurreta, no se dispersara y quedara en el país. Sí claro, pero eso no es una herencia, eso es un embolado, como se dice aquí. Y hubo que pensar mucho cómo afrontar poner eso a disposición para que alguien se lo llevara. De tal manera que primero se negoció con los jesuitas, y ellos habían conseguido un espacio en la curia, en la Ciudad Vieja, y el acuerdo con la curia se rompió. El director de la curia se casó, dejó los hábitos y la biblioteca se donó al Partido Nacional que a su vez se la dio a la Universidad de Montevideo (UM). Pero los libros estuvieron en fase de desinfección todavía un buen tiempo en la UM para hacerlos accesibles al público. Y yo creo que hay algunos libros allí que Moses se equivocó porque yo no quería que se donaran. Libros de cartografía del Río de la Plata que a mí me interesaban, pero bueno, se donaron y ya está. Mi padre nunca vendió. A mi me ofrecieron en el año $85 \mathrm{u}$ 87, 97 cuando murió mi padre. Mi padre fue director del CODICEN entre el 85 y el 90, por esa fecha es cuando va Wilson ${ }^{334}$ y Sanguinetti a ofrecer el cargo a mi casa, cuando empieza la democracia vigilada. Y mi padre muere en el 97 con 87 años. Yo creo que Sanguinetti estaba en su segundo mandato ${ }^{335}$, y yo fui a casa de gobierno, el edificio moderno ese, el edificio

\footnotetext{
${ }^{333}$ José Ellauri (número 484) es el nombre de la calle donde quedaba la casa de Pivel, ubicada en el barrio de Punta Carretas.

${ }^{334}$ Se refiere al líder del Partido Nacional Wilson Ferreira Aldunate (1919-1988).

${ }^{335}$ Es inexacto, Sanguinetti fue presidente en dos oportunidades, los períodos 1985-1990 y 1995-2000, por lo tanto, quien estaba al frente del ejecutivo era Lacalle Herrera.
} 
Libertad, fui con quien era el director del Archivo, que también era amiguete, y me preguntó por la biblioteca. Yo le dije que los Pivel no vendemos libros, los compramos, porque yo también soy de comprar libros, y Sanguinetti se rió y fue muy amable y cariñoso. Él hizo un precioso discurso cuando murió mi padre en el entierro. Tuvimos que enfrentar eso. Yo hablé con Moses, mi hermana no se metió para nada, no tenía ni idea. Yo hablé con Moses y le dije que aquí había que sacrificar algo para financiar esto. Porque tal como estaba no lo recibía nadie, porque mi padre tuvo derrame cerebral cuatro años antes de morir y ahí no se tocó nada. Y no tocar nada en Montevideo con la humedad que hay, imagínese. ¿Qué algún libro importante se vendió? Por supuesto, lo único que faltaba era que yo tuviera que sacar un crédito para colocar la herencia de mi padre en un sitio sin sacar un peso. Porque la biblioteca se donó en su integridad, el archivo no, el archivo se vendió y lo negocié yo personalmente. Pedí lo que pedí libre de impuestos. 


\section{LISTA CRONOLÓGICA DE OBRAS EDITADAS POR LA COMISIÓN EDITORA DE LA COLEC- CIÓN DE CLÁSICOS URUGUAYOS}

\section{Período colonial y revolucionario (1787-1814)}

Selección de escritos. Crónicas históricas (1787-1814), Juan Manuel Pérez Castellano, 1787-1814.

\section{Siglo XIX del Estado uruguayo (1830-1900)}

El parnaso oriental o la guirnalda poética de la República del Uruguay, Luciano Lira, 1835-1837.

Historia del territorio oriental del Uruguay, Juan M. de la Sota, 1841, con un capítulo de 1851.

El caudillismo y la revolución americana. Polémica, Manuel Herrera y Obes y Bernardo Prudencio Berro, $1847-$ 1848.

Selección de escritos. Tomo I. Observación sobre agricultura, José María Pérez Castellanos, 1848.

Diario de Viaje, Francisco Xavier de Viana, 1849- 1850.

Estudios históricos, políticos y sociales sobre el Río de la Plata, Alejandro Magariños Cervantes, 1854.

Diario histórico del sitio de Montevideo en los años 1812-13-14, Francisco Acuña de Figueroa, 1844 y 1854.

Descripción Geográfica del Territorio de la República Oriental del Uruguay. Tomo I. Acompañado de observaciones geológicas y cuadros estadísticos, José María Reyes, 1859.

Curso elemental de Derecho de Gentes. Tomo I, Gregorio Pérez Gomar, 1864.

Conferencias sobre Derecho Natural. Como introducción el curso de Derecho de Gentes, Gregorio Pérez Gomar, 1864.

Diario de la Campaña de las Fuerzas Aliadas contra el Paraguay, León de Palleja, 1865-1866.

Curso elemental de Derecho de Gentes. Tomo II, Gregorio Pérez Gomar, 1866.

Los tres gauchos orientales, Antonio D. Lussich, 1872.

La Educación del Pueblo, José Pedro Varela, 1874.

Deportación a La Habana en la barca «Puig». Historia de un atentado célebre, Agustín de Vedia, 1875.

La Legislación Escolar, José Pedro Varela, 1876.

El destino nacional y la universidad, José Pedro Varela, Carlos María Ramírez, recopilado 1876.

Memorias, César Díaz, 1878.

La leyenda Patria, Juan Zorrilla de San Martín, 1879.

Artigas, Carlos María Ramírez, 1884.

Las mujeres de Shakespeare, Luis Melián Lafinur, 1884.

Estudios literarios, Francisco Bauzá, 1885.

Escritos sociológicos. 1881-1885, Martín C. Martínez, recopilado: 1881-1885.

Estudios constitucionales, Francisco Bauzá, 1887.

Historia de la dominación española en el Uruguay, Francisco Bauzá, 1887.

Narraciones, Manuel P. Bernárdez, 1887 ?

Ismael, Eduardo Acevedo Díaz, 1888.

Tabaré, Juan Zorrilla de San Martín, 1888.

Vocabulario Rioplatense Razonado, Daniel Granada, 1889.

Nativa, Eduardo Acevedo Díaz, 1890. 
Grito de Gloria, Eduardo Acevedo Díaz, 1893.

Beba, Carlos Reyles, 1894.

Soledad y El combate de la tapera, Eduardo Acevedo Díaz, 1894.

Versitos Criollos, Elías Regules, 1894; Versos Criollos, 1900.

Montevideo Antiguo, Isidoro de María, 1887-1895.

Todos los cantos, Álvaro Armando Vasseur, 1898-1912.

Gaucha, Javier de Viana, 1899.

La raza de Caín, Carlos Reyles, 1900.

Ariel, Rodó, 1900 (junto a Liberalismo y jacobinismo).

Huerto cerrado, Juan Zorrilla de San Martín, 1900.

\section{Siglo xx del Uruguay (1901- 1961)}

Nativos, Santiago Maciel, 1901.

Liberalismo y jacobinismo, Rodó, 1906 (junto a Ariel).

Lauracha, Otto Miguel Cione, 1906.

Historia de un amor turbio, Horacio Quiroga, 1908.

Motivos de Proteo, José Enrique Rodó, 1909.

La Epopeya de Artigas, Zorrilla, 1910.

Las Instrucciones del Año XIII, Héctor Miranda, 1910.

Obras pedagógicas, Varela, 1910.

Arte, estética ideal, Pedro Figari, 1912.

El mirador de Próspero, Rodó, 1913.

Lanza y Sable, Eduardo Acevedo Díaz, 1914.

Motivos de Crítica, Osvaldo Crispo Acosta, 1914.

La agricultura colonial, Mariano B. Berro, 1914.

Crítica y arte. Tierra española. Visiones de Italia, Gustavo Gallinal, 1914 y 1920.

El Terruño y Primitivo, Carlos Reyles, 1916.

Paja Brava, El Viejo Pancho, 1916.

Sobre la propiedad de la tierra, Carlos Vaz Ferreira, 1918.

Doñarramona, José Pedro Bellán, 1918.

Praderas soleadas y otros poemas, Andrés Héctor Lerena Acevedo, 1918.

Las Lenguas de Diamante, Juana de Ibarbourou, 1919.

Ante la nueva Constitución, Dr. Martín C. Martínez, 1919.

Época colonial. La compañía de Jesús en Montevideo, Carlos Ferrés, 1919.

Pasar..., Mateo Magariños Solsona, 1920.

Crítica y arte. Tierra española. Visiones de Italia, Gustavo Gallinal, 1914 y 1920.

Estudios Filosóficos, José P. Massera, 1920 en adelante.

Sobre los Problemas Sociales, Carlos Vaz Ferreira, 1922.

La independencia nacional. Tomo II, Pablo Blanco Acevedo, 1922.

La Isla de los Cánticos, María Eugenia Vaz Ferreira, 1924 (póstuma). 
El sermón de la Paz, Juan Zorrilla de San Martín, 1924.

La cruzada de los Treinta y Tres, Luis Arcos Ferrand, 1925.

El Uruguay entre dos siglos, Mario Falcao Espalter, 1926.

Raza ciega y otros cuentos, Francisco Espínola, 1926 y 1961.

Crónicas de un crimen, Justino Zavala Muniz, 1926.

El libro de Ruth, Juan Zorrilla de San Martín, 1928.

Letras uruguayas, Gustavo Gallinal, 1928.

Poética y plástica, Emilio Oribe, 1930.

Purificación. Sede del protectorado de «Los Pueblos Libres». 1815-1818, Juan Antonio Rebella, 1933.

El Gobierno Colonial en el Uruguay y los orígenes de la nacionalidad. Tomo I, Pablo Blanco Acevedo, 1936.

Fermentario, Carlos Vaz Ferreira, 1938.

Anecdotario del uruguayo Santiago Marcos, Ramón Píriz Coelho, 1938.

Teseo. Los Problemas del Arte, Eduardo Dieste, 1940.

Paráfrasis, Roberto Sienra, 1941.

El narrador gaucho (novela en cuentos), selección de cuentos, Valentín García Sainz, 1945.

Dos ensayos constitucionales, Juan Andrés Ramírez, 1949.

La recuperación del objeto, Joaquín Torres García, 1952.

Un panorama del espiritu. Tomo I. El «Ariel» de Rodó, José G. Antuña, 1952.

Estudios históricos, Lorenzo Barbagelata, 1954 (desde 1907).

Raza ciega y otros cuentos, Francisco Espínola, 1926 y 1961.

Selección de prosas, Pedro Leonardo Ipuche, de 1931 hasta 1961.

Recopilaciones, antologías y misceláneas. 


\section{CATÁLOGO COLECCIÓN DE CLÁSICOS URUGUAYOS (1953-1982)}

1. Artigas

Autor: Carlos María Ramírez.

Montevideo, 1953, 423 páginas.

Prólogo: Luis Bonavita.

Terminado de imprimir: 30/6/1953.

Impresora: Colombino SA.

Original: 1884.

2. Fermentario

Autor: Carlos Vaz Ferreira

Montevideo. 1953, 203 páginas

Prólogo: Carlos Vaz Ferreira

Terminado de imprimir: 10/7/1953

Impresora: Colombino SA.

Original: 1938.

3. El Terruño y Primitivo

Autor: Carlos Reyles.

Montevideo, 1953, 321 páginas.

Prólogo: Ángel Rama.

Terminado de imprimir: 4/7/1953

Impresora: Bianchi Altuna.

Original: 1916.

4. Ismael

Autor: Eduardo Acevedo Díaz.

Montevideo, 1953, 361 páginas.

Prólogo: Roberto Ibáñez.

Terminado de imprimir: 9/1953, reimpresión en 1985.

Impresora: Uruguaya

Original: 1888.

5. Sobre los Problemas Sociales

Autor: Carlos Vaz Ferreira

Montevideo, 1953,143 páginas

Terminado de imprimir: 7/1953

Impresora: Uruguaya.

Original: 1922. 
6. Sobre la propiedad de la tierra

Autor: Carlos Vaz Ferreira

Montevideo, 1953, 375 páginas

Prólogo: Carlos Vaz Ferreira

Terminado de imprimir: 7/1953

Impresora: Uruguaya

Original: 1918.

7. Descripción Geográfica del Territorio de la República Oriental del Uruguay. Tomo I. Acompañado de observaciones geológicas y cuadros estadísticos

Autor: José María Reyes

Montevideo, 1953, 192 páginas

Prólogo: Juan E. Pivel Devoto

Terminado de imprimir: 22/08/1953, reimpreso en 1960.

Impresora: Colombino

Original: 1859.

8. Descripción Geográfica del Territorio de la República Oriental del Uruguay. Tomo II. Acompañado de observaciones geológicas y cuadros estadísticos

Autor: José María Reyes

Montevideo, 1953, 284 páginas

9. Estudios literarios

Autor: Francisco Bauzá.

Montevideo, 1953, 258 páginas.

Terminado de imprimir: 15/12/1953

Impresora: Impresora Uruguaya.

Original: 1885

10. Artículos

Autor: Sansón Carrasco

Montevideo, 1953, 398 páginas

Prólogo: José Pereira Rodríguez

Terminado de imprimir: 12/1953

Impresora: Bianchi Altuna.

11. Estudios Constitucionales

Autor: Francisco Bauzá

Montevideo, 1953, 413 páginas

Prólogo: Alfredo Castellanos

Terminado de imprimir: 12/1953

Impresora: Colombino. 
Original: 1887

12. Estudios Filosóficos

Autor: José P. Massera

Montevideo, 1954, 276 páginas

Prólogo: Arturo Ardao

Terminado de imprimir: 3/1954

Impresora: Uruguaya.

Original: 1920 en adelante.

\section{Paja Brava}

Autor: El Viejo Pancho.

Montevideo, 1954, 190 páginas.

Prólogo: Serafín J. García.

Terminado de imprimir: 10/12/1954

Impresora: Bianchi Altuna.

Original: 1916

14- Doñarramona

Autor: José Pedro Bellán.

Montevideo, 1954, 173 páginas.

Prólogo: José Pedro Díaz.

Terminado de imprimir: 10/12/1954

Impresora: Colombino.

Original: 1918

15- Soledad y el Combate de la Tapera

Autor: Eduardo Acevedo Díaz.

Montevideo, 1954, 99 páginas.

Prólogo: Francisco Espínola.

Terminado de imprimir: 6/1954

Impresora: Uruguaya.

Original: 1894.

16- Todos los cantos

Autor: Álvaro Armando Vasseur.

Montevideo, 1955, 293 páginas.

Prólogo: Emilio Frugoni.

Terminado de imprimir: 1/1955

Impresora: Colombino.

Original: 1898-1912. 
17- Narraciones

Autor: Manuel P. Bernárdez.

Montevideo, 1955, 167 páginas.

Prólogo: Juan José Morosoli.

Terminado de imprimir 3/1955.

Impresora: Colombino.

18- Tabaré

Autor: Juan Zorrilla de San Martín.

Montevideo, 1956, 231 páginas.

Prólogo: Alberto Zum Felde.

Terminado de imprimir: 6/1956.

Impresora: Impresora Uruguaya.

Original: 1888.

19- Gaucha

Autor: Javier de Viana.

Montevideo, 1956, 266 páginas.

Prólogo: Arturo Sergio Visca.

Terminado de imprimir: 6/1956.

Impresora: Impresora Uruguaya.

Original: 1899.

20- La Isla de los Cánticos

Autor: María Eugenia Vaz Ferreira.

Montevideo, 1956, 91 páginas.

Prólogo: Esther de Cáceres.

Terminado de imprimir:7/1956, reeditado en 1975.

Impresora: Impresora Uruguaya.

Original: 1929.

21- Motivos de Proteo. Tomo I

Autor: José Enrique Rodó

Montevideo, 1957, 150 páginas

Prólogo: Carlos Real de Azúa

Terminado de imprimir: 20/7/1957

Impresora: Impresora Uruguaya.

Original: 1909.

22- Motivos de Proteo. Tomo II 
Autor: José Enrique Rodó

Montevideo, 1957, 287 páginas

Terminado de imprimir: 20/7/1957

Impresora: Impresora Uruguaya.

23- Montevideo Antiguo. Tomo I. Tradiciones y Recuerdos

Autor: Isidoro de María.

Montevideo, 1957, 313 páginas.

Prólogo: Juan E. Pivel Devoto.

Terminado de imprimir: 6/1957, reeditado en octubre de 1976 e impreso por la Imprenta Nacional.

Impresora: Colombino.

Original: $1887-1895$

24- Montevideo Antiguo. Tomo II. Tradiciones y Recuerdos

Autor: Isidoro de María.

Montevideo, 1957, 365 páginas.

Terminado de imprimir: 6/1957, reeditado en octubre de 1976 e impreso por la Imprenta Nacional.

Impresora: Colombino.

25- Vocabulario Rioplatense Razonado. Tomo I

Autor: Daniel Granada

Montevideo, 1957, 227 páginas

Prólogo: Lauro Ayestarán

Terminado de imprimir: 6/1957

Impresora: Impresora Uruguaya.

Original: 1889.

26- Vocabulario Rioplatense Razonado. Tomo II

Autor: Daniel Granada

Montevideo, 1957, 267 páginas

Terminado de imprimir: 6/1957

Impresora: Impresora Uruguaya.

27- Diario de Viaje. Tomo I

Autor: Francisco Xavier de Viana

Montevideo, 1958, 295 páginas

Prólogo: Homero Martínez Moreno

Terminado de imprimir: 12/1958.

Impresora: Colombino.

Original: 1849-1850. 
28- Diario de viaje. Tomo II

Autor: Francisco Xavier de Viana

Montevideo, 1958, 297 páginas

Terminado de imprimir: 12/1958.

Impresora: Colombino.

29- Diario de la Campaña de las Fuerzas Aliadas contra el Paraguay. Tomo I

Autor: León de Palleja.

Montevideo, 1960, 380 páginas.

Prólogo: Eduardo de Salterain y Herrera.

Terminado de imprimir: 6/1960.

Impresora: Impresora Uruguaya.

Original: 1865-1866.

30- Diario de la Campaña de las Fuerzas Aliadas contra el Paraguay. Tomo II

Autor:León de Palleja.

Montevideo, 1960, 390 páginas.

Terminado de imprimir: 6/1960.

Impresora: Impresora Uruguaya.

31- Arte, estética ideal. Tomo I

Autor: Pedro Figari

Montevideo, 1960, 204 páginas.

Prólogo: Arturo Ardao

Terminado de imprimir: 10/1960, reeditado por la Imprenta Nacional en octubre de 1988.

Impresora: Colombino.

Original: 1912.

32- Arte, estética ideal. Tomo II

Autor: Pedro Figari

Montevideo, 1960, 250 páginas.

Terminado de imprimir: 10/1960, reeditado por la Imprenta Nacional en octubre de 1988.

Impresora: Colombino.

33- Arte, estética ideal. Tomo III.

Autor: Pedro Figari

Montevideo, 1960, 221 páginas.

Terminado de imprimir: 10/1960, reeditado por la Imprenta Nacional en octubre de 1988.

Impresora: Colombino. 
Autor: Santiago Maciel.

Montevideo, 1961, 171 páginas.

Prólogo: Jorge Albistur.

Terminado de imprimir: 11/1961.

Impresora: Colombino.

Original: 1901

35- Estudios históricos, políticos y sociales sobre el Río de la Plata. Tomo I

Autor: Alejandro Magariños Cervantes.

Montevideo, 1963, 396 páginas.

Prólogo: Juan E. Pivel Devoto.

Terminado de imprimir: 6/1963.

Impresora: Impresora Uruguaya.

Original: 1854.

36- Estudios históricos, políticos y sociales sobre el Río de la Plata. Tomo II Autor: Alejandro Magariños Cervantes.

Montevideo, 1963, 237 páginas.

Terminado de imprimir: 6/1963.

Impresora: Impresora Uruguaya.

37- La Epopeya de Artigas. Tomo I

Autor: Juan Zorrilla de San Martín.

Montevideo, 1963, 260 páginas.

Prólogo: Juan E. Pivel Devoto.

Terminado de imprimir: 8/1963.

Impresora: Barreiro y Ramos.

Original: 1910.

38- La Epopeya de Artigas. Tomo II

Autor: Juan Zorrilla de San Martín.

Montevideo, 1963, 290 páginas.

Terminado de imprimir: 8/1963.

Impresora: Barreiro y Ramos.

39- La Epopeya de Artigas. Tomo III

Autor: Juan Zorrilla de San Martín.

Montevideo, 1963, 282 páginas.

Terminado de imprimir: 8/1963.

Impresora: Barreiro y Ramos. 
40- La Epopeya de Artigas. Tomo IV

Autor: Juan Zorrilla de San Martín.

Montevideo, 1963, 276 páginas.

Terminado de imprimir: 8/1963.

Impresora: Barreiro y Ramos.

41- La Epopeya de Artigas. Tomo V

Autor: Juan Zorrilla de San Martín.

Montevideo, 1963, 334 páginas.

Terminado de imprimir: 8/1963.

Impresora: Barreiro y Ramos.

42- Las Lenguas de Diamante

Autor: Juana de Ibarbourou.

Montevideo, 1963, 132 páginas.

Prólogo: José Pereira Rodríguez.

Terminado de imprimir: 8/1963.

Impresora: Impresora Uruguaya.

Original: 1919.

43- Teseo. Los Problemas del Arte

Autor: Eduardo Dieste

Montevideo, 1964, 227 páginas

Prólogo: Esther de Cáceres

Terminado de imprimir: 3/1964.

Impresora: Barreiro y Ramos.

Original: 1940.

44- Ariel. Liberalismo y Jacobinismo

Autor: José Enrique Rodó

Montevideo, 1964, 188 páginas

Prólogo: José Pereira Rodríguez

Terminado de imprimir: 9/1964.

Impresora: Barreiro y Ramos.

Original: 1900 y 1906.

45- Pasar...

Autor: Mateo Magariños Solsona.

Montevideo, 1964, 292 páginas.

Prólogo: Arturo Sergio Visca.

Terminado de imprimir: 6/1964. 
Impresora: Barreiro y Ramos.

Original: 1920.

46- Las Instrucciones del Año XIII. Tomo I

Autor: Héctor Miranda.

Montevideo, 1964, 143 páginas.

Prólogo: Arturo Sergio Visca.

Terminado de imprimir: 6/1964.

Impresora: Barreiro y Ramos.

Original: 1910.

47- Las Instrucciones el Año XIII. Tomo II

Autor: Héctor Miranda.

Montevideo, 1964, 232 páginas.

Terminado de imprimir: 6/1964.

Impresora: Barreiro y Ramos.

48- Ante la nueva Constitución

Autor: Dr. Martín C. Martínez

Montevideo, 1964, 268 páginas

Prólogo: Héctor Gros Espiell

Terminado de imprimir: 8/1964.

Impresora: Barreiro y Ramos.

Original: 1919.

49- Obras pedagógicas. Tomo I

Autor: José Pedro Varela

Montevideo, 1964, 380 páginas

Prólogo: Arturo Ardao

Terminado de imprimir: 9/1964.

Impresora: Barreiro y Ramos.

Original: 1910.

50- Obras Pedagógicas. Tomo II. La Educación del Pueblo Autor: José Pedro Varela

Montevideo, 1964, 234 páginas

Terminado de imprimir: 9/1964.

Impresora: Barreiro y Ramos.

Original: 1874.

51- Obras Pedagógicas. Tomo I. La Legislación Escolar 
Autor: José Pedro Varela

Montevideo, 1964, 221 páginas

Terminado de imprimir: 9/1964

Impresora: Barreiro y Ramos.

Original: 1876.

52- Obras Pedagógicas. Tomo II. La Legislación Escolar

Autor: José Pedro Varela

Montevideo, 1964, 183 páginas

Terminado de imprimir: 9/1964.

Impresora: Barreiro y Ramos.

53- Nativa

Autor: Eduardo Acevedo Díaz.

Montevideo, 1964, 420 páginas.

Prólogo: Emir Rodríguez Monegal.

Terminado de imprimir: 10/1964.

Impresora: Barreiro y Ramos.

Original: 1890.

54- Grito de Gloria

Autor: Eduardo Acevedo Díaz.

Montevideo, 1964, 380 páginas.

Prólogo: Emir Rodríguez Monegal.

Terminado de imprimir: 10/1964.

Impresora: Barreiro y Ramos.

Original: 1893.

55- Selección de Poesías

Autor: Carlos Roxlo.

Montevideo, 1964, 163 páginas.

Prólogo: Eustaquio Tomé.

Terminado de imprimir: 11/1964.

Impresora: Barreiro y Ramos.

Original: 1893.

56- Los tres gauchos orientales

Autor: Antonio D. Lussich.

Montevideo, 1964, 346 páginas.

Prólogo: Eneida Sansone de Martínez.

Terminado de imprimir: 11/64 
Impresora: Barreiro y Ramos.

Original: 1883 [1872].

57- Versos criollos

Autor: Elías Regules.

Montevideo, 1965, 176 páginas.

Prólogo: Lauro Ayestarán.

Terminado de imprimir: 3/1965.

Impresora: Barreiro y Ramos.

Original: 1894.

58- Motivos de Crítica. Tomo I

Autor: Osvaldo Crispo Acosta "Lauxar"

Montevideo, 1965, 279 páginas

Prólogo: Domingo Luis Bordoli

Terminado de imprimir: 2/1965.

Impresora: Barreiro y Ramos.

Original: 1914.

59- Motivos de Crítica. Tomo II

Autor: Osvaldo Crispo Acosta "Lauxar"

Montevideo, 1965, 222 páginas

Terminado de imprimir: 2/1965.

Impresora: Barreiro y Ramos.

60- Motivos de Crítica. Tomo III

Autor: Osvaldo Crispo Acosta "Lauxar"

Montevideo, 1965, 237 páginas

Terminado de imprimir: 2/1965.

Impresora: Barreiro y Ramos.

61- Motivos de Crítica. Tomo IV

Autor: Osvaldo Crispo Acosta "Lauxar"

Montevideo, 1965, 325 páginas

Terminado de imprimir: 2/1965.

Impresora: Barreiro y Ramos.

62- Beba

Autor: Carlos Reyles.

Montevideo, 1965, 266 páginas.

Prólogo: Walter Rela. 
Terminado de imprimir: 5/1965

Impresora: Barreiro y Ramos.

Original: 1894.

63- Lanza y Sable

Autor: Eduardo Acevedo Díaz.

Montevideo, 1965, 357 páginas.

Prólogo: Emir Rodríguez Monegal.

Terminado de imprimir: 5/1965.

Impresora: Barreiro y Ramos.

Original: 1914.

64- Conferencias y Discursos. Tomo I

Autor: Juan Zorrilla de San Martín

Montevideo, 1965, 174 páginas

Prólogo: José G. Antuña

Terminado de imprimir: 6/1965

Impresora: Barreiro y Ramos.

65- Conferencias y Discursos. Tomo II

Autor: Juan Zorrilla de San Martín

Montevideo, 1965, 209 páginas

Terminado de imprimir: 6/1965

Impresora: Barreiro y Ramos.

66- Conferencias y Discursos. Tomo III

Autor: Juan Zorrilla de San Martín

Montevideo, 1965, 196 páginas

Terminado de imprimir: 6/1965

Impresora: Barreiro y Ramos.

67- El destino nacional y la universidad. Tomo I. Polémica

Autor: José Pedro Varela, Carlos María Ramírez

Montevideo, 1965, 276 páginas

Prólogo: Arturo Ardao

Terminado de imprimir: 6/1965.

Impresora: Barreiro y Ramos.

Original: 1876.

68- El destino nacional y la universidad. Tomo II. Polémica Autor: José Pedro Varela, Carlos María Ramírez 
Montevideo, 1965, 387 páginas

Terminado de imprimir: 6/1965.

Impresora: Barreiro y Ramos.

69- Antología

Autor: Delmira Agustini.

Montevideo, 1965, 65 páginas.

Prólogo: Esther de Cáceres.

Terminado de imprimir: 7/1965, reeditado en marzo de 1986 por la Imprenta Nacional.

Impresora: Barreiro y Ramos.

70- Selección de cuentos. Tomo I

Autor: Javier de Viana.

Montevideo, 1965, 231 páginas.

Prólogo: Arturo Sergio Visca.

Terminado de imprimir: 7/1965.

Impresora: Barreiro y Ramos.

71- Selección de cuentos. Tomo II

Autor: Javier de Viana.

Montevideo, 1965, 269 páginas.

Terminado de imprimir: 7/1965.

Impresora: Barreiro y Ramos.

72- Historia del territorio oriental del Uruguay. Tomo I

Autor: Juan M. de la Sota.

Montevideo, 1965, 191 páginas.

Prólogo: Juan E. Pivel Devoto.

Terminado de imprimir: 7/1965.

Impresora: Barreiro y Ramos.

Original: 1841-1851.

73- Historia del territorio oriental del Uruguay. Tomo II

Autor: Juan M. de la Sota.

Montevideo, 1965, 241 páginas.

Terminado de imprimir: 7/1965.

Impresora: Barreiro y Ramos.

74- Cuentos

Autor: Benjamín Fernández y Medina.

Montevideo, 1965, 289 páginas. 
Prólogo: Arturo Sergio Visca.

Terminado de imprimir: 9/1965.

Impresora: Barreiro y Ramos.

75- La recuperación del objeto. Tomo I

Autor: Joaquín Torres García

Montevideo, 1965, 227 páginas

Prólogo: Esther de Cáceres

Terminado de imprimir: 8/1965.

Impresora: Impresora Uruguaya.

Original: 1952.

76- La recuperación del objeto. Tomo II

Autor: Joaquín Torres García

Montevideo, 1965, 224 páginas

Terminado de imprimir: 8/1965.

Impresora: Impresora Uruguaya.

77- Deportación a La Habana en la barca "Puig". Historia de un atentado célebre Autor: Agustín de Vedia.

Montevideo, 1965, 193 páginas.

Prólogo: Eustaquio Tomé.

Terminado de imprimir: 9/1965.

Impresora: Impresora Uruguaya.

Original: 1875.

78- Escritos sociológicos. 1881-1885

Autor: Dr. Martín C. Martínez

Montevideo, 1965, 176 páginas

Prólogo: Arturo Ardao

Terminado de imprimir: 9/1965.

Impresora: Impresora Uruguaya.

Original: 1881-1885.

79- El mirador de Próspero. Tomo I

Autor: José Enrique Rodó

Montevideo, 1965, 199 páginas

Prólogo: Carlos Real de Azúa

Terminado de imprimir: 9/1965

Impresora: Barreiro y Ramos.

Original: 1913. 
80- El mirador de Próspero. Tomo II

Autor: José Enrique Rodó

Montevideo, 1965, 357 páginas

Terminado de imprimir: 9/1965.

Impresora: Barreiro y Ramos.

81- Educación y arte

Autor: Pedro Figari

Montevideo, 1965, 226 páginas

Prólogo: Arturo Ardao

Terminado de imprimir: 10/1965.

Impresora: Impresora Uruguay.

Original: 1900-1925.

82- Antología

Autor: Francisco Acuña de Figueroa.

Montevideo, 1965, 182 páginas.

Prólogo: Armando D. Pirotto.

Terminado de imprimir: 11/1965.

Impresora: Barreiro y Ramos.

83- Selección de poesías

Autor: Romildo Risso.

Montevideo, 1965, 213 páginas.

Prólogo: Domingo Luis Bordoli.

Terminado de imprimir: 11/1965.

Impresora: Impresora Uruguaya.

84- Ensayos. Tomo I

Autor: Carlos Reyles

Montevideo, 1965, 271 páginas

Prólogo: Arturo Sergio Visca

Terminado de imprimir: 11/1965.

Impresora: Barreiro y Ramos.

85- Ensayos. Tomo II

Autor: Carlos Reyles

Montevideo, 1965, 206 páginas

Terminado de imprimir: 11/1965. 
Impresora: Barreiro y Ramos.

86- Ensayos. Tomo III

Autor: Carlos Reyles

Montevideo, 1965, 298 páginas

Terminado de imprimir: 11/1965.

Impresora: Barreiro y Ramos.

87- Teatro completo. Tomo I

Autor: Ernesto Herrera.

Montevideo, 1965, 140 páginas.

Prólogo: Walter Rela.

Terminado de imprimir: 11/1965.

Impresora: Barreiro y Ramos.

88- Teatro completo. Tomo II

Autor: Ernesto Herrera

Montevideo, 1965, 196 páginas

Terminado de imprimir: 11/1965.

Impresora: Barreiro y Ramos.

89- Los modernistas. Tomo I

Autor: Víctor Pérez Petit.

Montevideo, 1965, 208 páginas.

Prólogo: Nicolás Fusco Sansone.

Terminado de imprimir: 11/1965.

Impresora: Barreiro y Ramos.

90- Los modernistas. Tomo II

Autor: Víctor Pérez Petit.

Montevideo, 1965, 251 páginas.

Terminado de imprimir: 11/1965.

Impresora: Barreiro y Ramos.

91- Las mujeres de Shakespeare

Autor: Luís Melian Lafinur.

Montevideo, 1965, 186 páginas.

Prólogo: José G. Antuña.

Terminado de imprimir: 1/1966.

Impresora: Barreiro y Ramos.

Original: 1884. 
92- Selección de escritos.

Autor: Dámaso A. Larrañaga

Montevideo, 1965, 254 páginas

Prólogo: Alfredo Castellanos

Terminado de imprimir: 2/1966.

Impresora: Barreiro y Ramos.

93- Escritos filosóficos.

Autor: Prudencio Vázquez y Vega

Montevideo, 1965, 228 páginas

Prólogo: Sergio Pittaluga Stewart

Terminado de imprimir: 11/1968, compaginado en 1965.

Impresora: Barreiro y Ramos.

94- La raza de Caín

Autor: Carlos Reyles.

Montevideo, 1965, 298 páginas.

Prólogo: Carlos Martínez Moreno.

Terminado de imprimir: 1/1966.

Impresora: Impresora Uruguaya.

Original: 1900.

95- Historia de la dominación española en el Uruguay. Tomo I (dos partes)

Autor: Francisco Bauzá.

Montevideo, 1965, 254 páginas.

Prólogo: Juan E. Pivel Devoto.

1880-1882, 1895-1897

Terminado de imprimir: 1/1966.

Impresora: Barreiro y Ramos.

Originales: $1880-1882$ y $1898-1897$.

96- Historia de la dominación española en el Uruguay. Tomo II

Autor: Francisco Bauzá.

Montevideo, 1965, 370 páginas.

Terminado de imprimir: 1/1967.

Impresora: Barreiro y Ramos.

97- Historia de la dominación española en el Uruguay. Tomo III

Autor: Francisco Bauzá.

Montevideo, 1965, 420 páginas. 
Terminado de imprimir:

Terminado de imprimir: 12/1967.

Impresora: Barreiro y Ramos.

98- Historia de la dominación española en el Uruguay. Tomo IV

Autor: Francisco Bauzá.

Montevideo, 1965, 394 páginas.

Terminado de imprimir: 12/1967.

Impresora: Barreiro y Ramos.

99- Historia de la dominación española en el Uruguay. Tomo V

Autor: Francisco Bauzá.

Montevideo, 1965, 415 páginas.

Terminado de imprimir: 1/1966.

Impresora: Barreiro y Ramos.

100- Historia de la dominación española en el Uruguay. Tomo VI

Autor: Francisco Bauzá.

Montevideo, 1965, 444 páginas.

Terminado de imprimir: 12/1967.

Impresora: Barreiro y Ramos.

101- Selección de cuentos. Tomo I

Autor: Horacio Quiroga.

Montevideo, 1966, 229 páginas.

Prólogo: Emir Rodríguez Monegal.

Terminado de imprimir: 6/1966.

Impresora: Barreiro y Ramos.

102- Selección de cuentos. Tomo II

Autor: Horacio Quiroga.

Montevideo, 1966, 341 páginas.

Terminado de imprimir: 6/1966.

Impresora: Barreiro y Ramos.

103- Conferencias de Derecho Constitucional

Autor: Carlos María Ramírez

Montevideo, 1966, 270 páginas

Prólogo: Héctor Gros Espiell

Terminado de imprimir: 8/1966.

Impresora: Barreiro y Ramos. 
104- Antología

Autor: Fernán Silva Valdez.

Montevideo, 1966, 251 páginas.

Prólogo: Arturo Sergio Visca.

Terminado de imprimir: 11/1966.

Impresora: Barreiro y Ramos.

105- Selección de cuentos. Tomo I

Autor: Yamandú Rodríguez.

Montevideo, 1966, 221 páginas.

Prólogo: Domingo Luis Bordoli.

Terminado de imprimir: 10/1966.

Impresora: Barreiro y Ramos.

106- Selección de cuentos. Tomo II

Autor: Yamandú Rodríguez.

Montevideo, 1966, 326 páginas.

Terminado de imprimir: 10/1966.

Impresora: Barreiro y Ramos.

107- Crónicas de un crimen

Autor: Justino Zavala Muniz

Montevideo, 1966, 276 páginas

Prólogo: Arturo Sergio Visca

Terminado de imprimir: 11/1966.

Impresora: Barreiro y Ramos.

Original: 1926.

108- Anecdotario del uruguayo Santiago Marcos

Autor: Ramón Píriz Coelho.

Montevideo, 1966, 184 páginas.

Prólogo: Arturo Sergio Visca.

Terminado de imprimir: 8/1966.

Impresora: Barreiro y Ramos.

Original: 1938.

109- Lauracha

Autor: Otto Miguel Cione.

Montevideo, 1966, 283 páginas.

Prólogo: Arturo Sergio Visca. 
Terminado de imprimir: 9/1966.

Impresora: Barreiro y Ramos.

Original: 1906.

110- El caudillismo y la revolución americana. Polémica

Autores: Manuel Herrera y Obes y Bernardo Prudencio Berro.

Montevideo, 1966, 155 páginas.

Prólogo: Juan E. Pivel Devoto.

Terminado de imprimir: 10/1966.

Impresora: Uruguaya Colombino.

111- Escritos selectos

Autor: Bernardo Prudencio Berro.

Montevideo, 1966, 350 páginas.

Prólogo: Juan E. Pivel Devoto.

Terminado de imprimir: 12/1966.

Impresora: Uruguaya Colombino.

112- Estudios históricos

Autor: Lorenzo Barbagelata.

Montevideo, 1966, 131 páginas.

Prólogo: Eustaquio Tomé.

Terminado de imprimir: 12/1966.

Impresora: Barreiro y Ramos.

113- Obras poéticas

Autor: Julio Herrera y Reissig.

Montevideo, 1966, 279 páginas.

Prólogo: Alberto Zum Felde.

Terminado de imprimir: 12/1966, reeditado en julio de 1976 por Monteverde.

Impresora: Barreiro y Ramos.

114- Conferencias sobre Derecho Natural. Como introducción el curso de Derecho de Gentes Autor: Gregorio Pérez Gomar

Montevideo, 1966, 176 páginas

Prólogo: Emilio Siemens Amaro

Terminado de imprimir: 12/1966.

Impresora: Monteverde.

Original: 1864.

115- Curso elemental de Derecho de Gentes. Tomo I 
Autor: Gregorio Pérez Gomar

Montevideo, 1967, 238 páginas

Terminado de imprimir: 12/1966.

Impresora: Monteverde.

Original: 1864-1866.

116- Curso elemental de Derecho de Gentes. Tomo II

Autor: Gregorio Pérez Gomar

Montevideo, 1967, 196 páginas

Terminado de imprimir: 12/1966.

Impresora: Monteverde.

117- Raza ciega y otros cuentos

Autor: Francisco Espínola.

Montevideo, 1967, 173 páginas.

Prólogo: Esther de Cáceres.

Terminado de imprimir: 1/1967.

Impresora: Barreiro y Ramos.

118- Dos ensayos constitucionales

Autor: Juan Andrés Ramírez

Montevideo, 1967, 227 páginas

Prólogo: Ariosto D. González

Terminado de imprimir: 2/1967.

Impresora: Uruguaya Colombino.

Original: 1945.

119- Cartas íntimas

Autor: Rafael Barrett

Montevideo, 1967, 124 páginas

Prólogo: Luis Hierro Gambardela

Terminado de imprimir: 2/1967.

Impresora: Barreiro y Ramos.

120- Praderas soleadas y otros poemas

Autor: Andrés Héctor Lerena Acevedo.

Montevideo, 1967, 104 páginas.

Prólogo: Giselda Zani.

Terminado de imprimir: 1/1967.

Impresora: Barreiro y Ramos. 
121- Teatro. Tomo I

Autor: Florencio Sánchez.

Montevideo, 1967, 230 páginas.

Prólogo: Walter Rela.

Terminado de imprimir: 10/1967, reeditado en diciembre de 1975 por Monteverde.

Impresora: Barreiro y Ramos.

122- Teatro. Tomo II

Autor: Florencio Sánchez.

Montevideo, 1967, 290 páginas.

Terminado de imprimir: 10/1967, reeditado en diciembre de 1975 por Monteverde.

Impresora: Barreiro y Ramos.

123- Antología

Autor: Juana de Ibarbourou.

Montevideo, 1967, 150 páginas.

Prólogo: Dora Isella Russell.

Terminado de imprimir: 12/1967.

Impresora: Barreiro y Ramos.

124- Crítica y arte. Tierra española. Visiones de Italia

Autor: Gustavo Gallinal

Montevideo, 1967, 282 páginas

Prólogo: Carlos Real de Azúa

Terminado de imprimir: 12/1967.

Impresora: Barreiro y Ramos.

125- Letras uruguayas

Autor: Gustavo Gallinal

Montevideo, 1967, 402 páginas

Prólogo: Carlos Real de Azúa

Terminado de imprimir:

Impresora: Barreiro y Ramos.

Original: 1928.

126- Historia de un amor turbio

Autor: Horacio Quiroga.

Montevideo, 1968, 91 páginas.

Prólogo: Emir Rodríguez Monegal.

Terminado de imprimir: 6/1968.

Impresora: Barreiro y Ramos. 
Original: 1908.

127- Selección de prosas. Tomo I

Autor: Pedro Leonardo Ipuche.

Montevideo, 1968, 211 páginas.

Prólogo: Domingo Luis Bordoli.

Terminado de imprimir: 8/1968.

Impresora: Barreiro y Ramos.

128- Selección de prosas. Tomo II

Autor: Pedro Leonardo Ipuche.

Montevideo, 1968, 223 páginas.

Terminado de imprimir: 8/1968.

Impresora: Barreiro y Ramos.

129- Memorias

Autor: César Díaz.

Montevideo, 1968, 366 páginas.

Terminado de imprimir: 7/1968.

Impresora: Barreiro y Ramos.

Original: 1878.

130- Selección de escritos. Crónicas históricas (1787-1814)

Autor: Juan Manuel Pérez Castellano.

Montevideo, 1968, 229 páginas.

Prólogo: Alfredo R. Castellanos.

Terminado de imprimir: 9/1968.

Impresora: Barreiro y Ramos.

131- Selección de escritos. Tomo I. Observación sobre agricultura.

Autor: José María Pérez Castellanos.

Montevideo, 1968, 330 páginas.

Terminado de imprimir: 9/1968

Impresora: Barreiro y Ramos.

Original: 1848.

132- Selección de escritos. Tomo II. Observación sobre agricultura.

Autor: José María Pérez Castellanos.

Montevideo, 1968, 293 páginas.

Terminado de imprimir: 9/1968

Impresora: Barreiro y Ramos. 
133- Paráfrasis

Autor: Roberto Sienra.

Montevideo, 1968, 285 páginas.

Prólogo: Arturo Sergio Visca.

Terminado de imprimir:

Impresora: Monteverde.

Original: 1941.

134- Poética y plástica. Tomo I

Autor: Emilio Oribe.

Montevideo, 1968, 279 páginas.

Prólogo: Alfonso Llambías de Azevedo.

Terminado de imprimir: 12/1968.

Impresora: Uruguay Colombino.

Original: 1930.

135- Poética y plástica. Tomo II

Autor: Emilio Oribe.

Montevideo, 1968, 283 páginas.

Terminado de imprimir: 12/1968.

Impresora: Uruguay Colombino.

136- Un panorama del espíritu. Tomo I. El "Ariel” de Rodó.

Autor: José G. Antuña.

Montevideo, 1969, 308 páginas.

Prólogo: Raúl Montero Bustamante.

Terminado de imprimir: 11/1969.

Impresora: Barreiro y Ramos.

Original: 1930.

137- Un panorama del espíritu. Tomo I. El "Ariel” de Rodó.

Autor: José G. Antuña.

Montevideo, 1969, 329 páginas.

Terminado de imprimir: 11/1969.

Impresora: Barreiro y Ramos.

138- Selección de cuentos.

Autor: Adolfo Montiel Ballesteros.

Montevideo, 1970, 308 páginas.

Prólogo: Domingo Luis Bordoli. 
Terminado de imprimir: 8/1970.

Impresora: Uruguaya Colombino.

139- Antología de poetas modernistas menores

Selección y prólogo: Arturo Sergio Visca.

Montevideo, 1971, 392 páginas.

Terminado de imprimir: 5/1971.

Impresora: Monteverde.

140- Estudios sociales y económicos. Tomo I.

Autor: Francisco Bauzá.

Montevideo, 1972, 400 páginas.

Prólogo: Juan E. Pivel Devoto.

Terminado de imprimir: 8/1972.

Impresora: Barreiro y Ramos.

141- Estudios sociales y económicos. Tomo II

Autor: Francisco Bauzá.

Montevideo, 1972, 248 páginas.

Prólogo: Raúl Montero Bustamante.

Terminado de imprimir: 8/1972.

Impresora: Barreiro y Ramos.

142- Selección de Discursos. Tomo I.

Autor: Francisco Acuña de Figueroa.

Montevideo, 1972, 308 páginas.

Prólogo: Héctor H. Muiños.

Terminado de imprimir: 9/1972.

Impresora: Barreiro y Ramos.

143- Selección de Discursos. Tomo II

Autor: Francisco Acuña de Figueroa.

Montevideo, 1972, 308 páginas.

Terminado de imprimir: 9/1972.

Impresora: Barreiro y Ramos.

144- Selección de Discursos. Tomo III

Autor: Francisco Acuña de Figueroa.

Montevideo, 1972, 308 páginas.

Terminado de imprimir: 9/1972.

Impresora: Barreiro y Ramos. 
145- La independencia nacional. Tomo I

Autor: AA. VV.

Montevideo, 1975, 270 páginas.

Prólogo: Juan E. Pivel Devoto.

Terminado de imprimir: 5/1975.

Impresora: Barreiro y Ramos.

146- La independencia nacional. Tomo II

Autor: Pablo Blanco Acevedo

Montevideo, 1975, 292 páginas.

Terminado de imprimir: 5/1975.

Impresora: Barreiro y Ramos.

147- Época colonial. La compañía de Jesús en Montevideo

Autor: Carlos Ferrés.

Montevideo, 1975, 367 páginas.

Prólogo: Juan Villegas.

Terminado de imprimir: 8/1978.

Impresora: Uruguay Colombino.

Original: 1919.

148- La agricultura colonial.

Autor: Mariano B. Berro.

Montevideo, 1975, 400 páginas.

Prólogo: Ernesto Villegas Suárez.

Terminado de imprimir: 10/1975.

Impresora: Impresora Rex.

Original: 1914.

149- El Gobierno Colonial en el Uruguay y los orígenes de la nacionalidad. Tomo I Autor: Pablo Blanco Acevedo.

Montevideo, 1975, 314 páginas.

Prólogo: Raúl Montero Bustamante.

Terminado de imprimir: 12/1975.

Impresora: Barreiro y Ramos.

Original: 1929.

150- El Gobierno Colonial en el Uruguay y los orígenes de la nacionalidad. Tomo II Autor: Pablo Blanco Acevedo.

Montevideo, 1975, 354 páginas. 
Terminado de imprimir: 12/1975.

Impresora: Barreiro y Ramos.

151- La cruzada de los Treinta y Tres

Autor: Luis Arcos Ferrand.

Montevideo, 1976, 313 páginas.

Prólogo: Elisa Silva Cazet.

Terminado de imprimir: 4/1975.

Impresora: Impresora Cordón.

152- Páginas de historia

Autor: Carlos María Ramírez.

Montevideo, 1978, 348 páginas.

Prólogo: Raúl Montero Bustamante.

Terminado de imprimir: 2/1978.

Impresora: Impresora Rex.

153- El narrador gaucho (novela en cuentos), selección de cuentos

Autor: Valentín García Sainz.

Montevideo, 1978, 236 páginas.

Prólogo: Domingo Luis Bordoli.

Terminado de imprimir: 9/1978.

Impresora: Barreiro y Ramos.

154- Ensayos. Tomo I. El sermón de la Paz.

Autor: Juan Zorrilla de San Martín.

Montevideo, 1978, 161 páginas.

Prólogo: Arturo Sergio Visca.

Terminado de imprimir: 9/1978.

Impresora: Barreiro y Ramos.

Original: 1924.

155- Ensayos. Tomo II. El libro de Ruth.

Autor: Juan Zorrilla de San Martín.

Montevideo, 1978, 177 páginas.

Terminado de imprimir: 9/1978.

Impresora: Barreiro y Ramos.

Original: 1928.

156- Ensayos. Tomo III. Huerto Cerrado.

Autor: Juan Zorrilla de San Martín. 
Montevideo, 1978, 157 páginas.

Terminado de imprimir: 9/1978.

Impresora: Barreiro y Ramos.

Original: 1900.

157- Diario histórico del sitio de Montevideo en los años 1812-13-14. Tomo I

Autor: Francisco Acuña de Figueroa.

Montevideo, 1978, 440 páginas.

Prólogo: Roger Basagoda.

Terminado de imprimir: 10/1978.

Impresora: Impresora Nacional.

Original: 1844.

158- Diario histórico del sitio de Montevideo en los años 1812-13-14. Tomo II

Autor: Francisco Acuña de Figueroa.

Montevideo, 1978, 365 páginas.

Terminado de imprimir: 10/1978.

Impresora: Impresora Nacional.

159- El parnaso oriental o la guirnalda poética de la República del Uruguay. Tomo I Autor: Luciano Lira.

Montevideo, 1981, 348 páginas.

Prólogo: Juan E. Pivel Devoto.

Terminado de imprimir: 6/1981.

Impresora: Barreiro y Ramos.

Original: 1837.

160- El parnaso oriental o la guirnalda poética de la República del Uruguay. Tomo II Autor: Luciano Lira.

Montevideo, 1981, 430 páginas.

Terminado de imprimir: 6/1981.

Impresora: Barreiro y Ramos.

161- El parnaso oriental o la guirnalda poética de la República del Uruguay. Tomo III Autor: Luciano Lira.

Montevideo, 1981, 374 páginas.

Terminado de imprimir: 6/1981.

Impresora: Barreiro y Ramos.

162- El Uruguay entre dos siglos

Autor: Mario Falcao Espalter. 
Montevideo, 1981, 239 páginas.

Terminado de imprimir: 10/1983.

Impresora: Impresora Rex.

Original: 1926.

163- Purificación. Sede del protectorado de «Los Pueblos Libres». 1815-1818

Autor: Juan Antonio Rebella.

Montevideo, 1981, 189 páginas.

Terminado de imprimir: 8/1981.

Impresora: Impresora Rex.

Original: 1933.

164- La leyenda Patria.

Autor: Juan Zorrilla de San Martín.

Montevideo, 1978, 119 páginas.

Introducción: Eustaquio Tomé

Estudio crítico: Arturo Sergio Visca.

Terminado de imprimir: 5/1979.

Impresora: Barreiro y Ramos.

Original: 1897, publicación em base a la edición de 1930.

165- Antología. Tomo I.

Autor: Carlos Sabat Ercasty.

Montevideo, 1982, 236 páginas.

Selección y prólogo: Dora Isabel Russell.

Terminado de imprimir: 4/1983.

Impresora: Carlos Casares Impresores.

166- Antología. Tomo II.

Autor: Carlos Sabat Ercasty.

Montevideo, 1982, 309 páginas.

Terminado de imprimir: 4/1983.

Impresora: Carlos Casares Impresores. 


\section{BIBLIOTECA INTERNACIONAL DE OBRAS FAMOSAS}

\section{Tomo 19}

Zorrilla de San Martín, Juan, Los funerales de Tabaré (Tomo 19).

Berro, Adolfo, Yandubayú y Liropeya (Tomo 19).

Bauzá, Francisco, Proceso de alta traición (Tomo 19).

Acuña de Figueroa, Francisco, Himno Nacional de la República Oriental del Uruguay (Tomo 19).

Ramírez, Carlos María, Grandeza é infortunios de Bolívar (Tomo 19).

Montes, Victoriano E., El Tambor de San Martín (Tomo 19).

Bauzá, Francisco, Los poetas de la revolución (Tomo 19).

Acevedo Díaz, Eduardo, Ismael (Tomo 19).

Berro, Aurelio, Al monumento elevado en la Florida (Tomo 19).

Rodó, José Enrique, El espíritu de Goethe (Tomo 19).

Hidalgo, Bartolomé, Diálogo de Chano y Contreras (Tomo 19).

Larrañaga, Dámaso Antonio, Oración inaugural, en la apertura de la Biblioteca pública de Montevideo (Tomo 19).

Ramírez, Carlos María, Artigas (Tomo 19).

Pérez, Abel J., Artigas (Tomo 19).

De Santiago, Ramón, La loca de Bequeló (Tomo 19).

De Viana, Javier, El viejo caudillo (Tomo 19).

Sierra Carranza, José M., A una paraguaya (Tomo 19).

Maeso, Carlos M., El tiempo de los tres botones (Tomo 19).

Sastre, Marcos, El viaje á las islas (Tomo 19).

Melián Lanifur, Luis, El canto de la alondra (Tomo 19).

Roxlo, Carlos, La trilla (Tomo 19).

Acevedo Díaz, Eduardo, Incendio de un campo (Tomo 19).

Fernández Medina, Benjamín, Campera (Tomo 19).

Muñoz, Daniel, La feria (Tomo 19).

Regules, Elías, Mi tapera (Tomo 19).

Lamas, Andrés, Poesía Nacional (Tomo 19).

Magariños Cervantes, Alejandro, La gloria (Tomo 19).

Gómez, Juan Carlos, El «Celiar» de Magariños Cervantes (Tomo 19).

Gómez, Juan Carlos, Ida y vuelta (Tomo 19).

Gómez, Juan Carlos, Desconsuelo (Tomo 19).

Becchi, Constantino, A la memoria de Juan C. Gómez (Tomo 19).

Roxlo, Carlos, Andresillo (Tomo 19).

Blanco, Juan Carlos, Los pueblos de América (Tomo 19).

Acuña de Figueroa, Francisco, A un coplero plagiario (Tomo 19).

Falco, Ángel, El beso de América (Tomo 19).

Zorrilla de San Martín, Juan, El mensaje de América (Tomo 19).

Acuña de Figueroa, Francisco, La culti-parla (Tomo 19).

Acuña de Figueroa, Francisco, No perdonar ni al demonio (Tomo 19).

De Vedia, Agustín, Derecho constitucional é internacional (Tomo 19). 
Sienra Carranza, José, Carta (Tomo 19).

Acuña de Figueroa, Francisco, Una momia (Tomo 19).

Martínez Vigil, Daniel, Siempre á ti (Tomo 19).

Fragueiro, Rafael, Rondel (Tomo 19).

\section{Tomo 20}

Martínez Vigil, Carlos, Cave ne cadas (Tomo 20).

Agustini, Delmira, La sed (Tomo 20).

Zum Felde, Alberto, El solitario llama (Tomo 20).

Bustamante, Pedro, Del valor cívico (Tomo 20).

Berro, Aurelio, A la industria (Tomo 20).

Blixen, Samuel, Cuento de hadas (Tomo 20).

Sánchez, Florencio, Nuestros hijos (Tomo 20).

Herrera y Obes, Julio, Alfredo Ténnyson (Tomo 20).

Nin Frías, José, Pensamientos (Tomo 20).

Zubillaga, Juan A., «Redención», novela de Ángel Estrada (Tomo 20).

Rodó, José Enrique, Los seis peregrinos (Tomo 20).

Martínez Vigil, Daniel, Símbolos (Tomo 20).

Herrera y Reissig, Julio, Poesías: El banco del suplicio, el suicidio de las almas, el viaje (Tomo 20).

Vaz Ferreira, Carlos, Reacciones (Tomo 20).

Vaz Ferreira, María Eugenia, Invicta (Tomo 20).

Vaz Ferreira, María Eugenia, La viejecita (Tomo 20).

\section{Tomo 21}

Figueroa, Francisco, Andar cubierto (Tomo 21).

Acuña de Figueroa, Francisco Epigramas (Tomo 21).

\section{Tomo 24}

Reyles, Carlos, Vesania amorosa (Tomo 24).

Pérez Petit, Víctor, Mi caballo (Tomo 24).

Pérez Petit, Víctor, Heroísmo (Tomo 24).

Bernández, Manuel, El desquite (Tomo 24).

Castell, Adela, Tus ojos de esmeralda (Tomo 24).

Frugoni, Emilio, Súplica (Tomo 24).

Rodó, José Enrique, Ariel (Tomo 24).

De Salterain, Joaquín, Helénica (Tomo 24).

Schinca, Francisco Alberto, ¡Evohé! (Tomo 24).

Kubly, Enrique, El principio y el fin (Tomo 24).

Floro Costa, Ángel, La lucha por la vida. - Nirvana (Tomo 24).

Sánchez, Ricardo, Ante la tumba de un amigo (Tomo 24).

Papini y Zas, Guzmán, A un cardenal (Tomo 24).

Vaz Ferreira, Carlos, Moral de periodistas (Tomo 24).

Martínez Vigil, Carlos, La educación pública (Tomo 24).

Soca, Francisco, La juventud es la legión de la gloria (Tomo 24). 
Varela, José Pedro, Gobierno de la escuela (Tomo 24).

Thévenin, Leopoldo, En relación (Tomo 24).

\section{Todos}

Acevedo Díaz, Eduardo, Incendio de un campo (Tomo 19).

Acevedo Díaz, Eduardo, Ismael (Tomo 19).

Acuña de Figueroa, Francisco Epigramas (Tomo 21).

Acuña de Figueroa, Francisco, A un coplero plagiario (Tomo 19).

Acuña de Figueroa, Francisco, Andar cubierto (Tomo 21).

Acuña de Figueroa, Francisco, Himno Nacional de la República Oriental del Uruguay (Tomo 19).

Acuña de Figueroa, Francisco, La culti-parla (Tomo 19).

Acuña de Figueroa, Francisco, No perdonar ni al demonio (Tomo 19).

Acuña de Figueroa, Francisco, Una momia (Tomo 19).

Agustini, Delmira, La sed (Tomo 20).

Bauzá, Francisco, Los poetas de la revolución (Tomo 19).

Bauzá, Francisco, Proceso de alta traición (Tomo 19).

Becchi, Constantino, A la memoria de Juan C. Gómez (Tomo 19).

Bernández, Manuel, El desquite (Tomo 24).

Berro, Adolfo, Yandubayú y Liropeya (Tomo 19).

Berro, Aurelio, A la industria (Tomo 20).

Berro, Aurelio, Al monumento elevado en la Florida (Tomo 19).

Blanco, Juan Carlos, Los pueblos de América (Tomo 19).

Blixen, Samuel, Cuento de hadas (Tomo 20).

Bustamante, Pedro, Del valor cívico (Tomo 20).

Castell, Adela, Tus ojos de esmeralda (Tomo 24).

De Salterain, Joaquín, Helénica (Tomo 24).

De Santiago, Ramón, La loca de Bequeló (Tomo 19).

De Vedia, Agustín, Derecho constitucional é internacional (Tomo 19).

De Viana, Javier, El viejo caudillo (Tomo 19).

Falco, Ángel, El beso de América (Tomo 19).

Fernández Medina, Benjamín, Campera (Tomo 19).

Floro Costa, Ángel, La lucha por la vida. —Nirvana (Tomo 24).

Fragueiro, Rafael, Rondel (Tomo 19).

Frugoni, Emilio, Súplica (Tomo 24).

Gómez, Juan Carlos, Desconsuelo (Tomo 19).

Gómez, Juan Carlos, El «Celiar» de Magariños Cervantes (Tomo 19).

Gómez, Juan Carlos, Ida y vuelta (Tomo 19).

Herrera y Obes, Julio, Alfredo Ténnyson (Tomo 20).

Herrera y Reissig, Julio, Poesías: El banco del suplicio, el suicidio de las almas, el viaje (Tomo 20).

Hidalgo, Bartolomé, Diálogo de Chano y Contreras (Tomo 19).

Kubly, Enrique, El principio y el fin (Tomo 24).

Lamas, Andrés, Poesía Nacional (Tomo 19). 
Larrañaga, Dámaso Antonio, Oración inaugural, en la apertura de la Biblioteca pública de Montevideo (Tomo 19).

Maeso, Carlos M., El tiempo de los tres botones (Tomo 19).

Magariños Cervantes, Alejandro, La gloria (Tomo 19).

Martínez Vigil, Carlos, Cave ne cadas (Tomo 20).

Martínez Vigil, Carlos, La educación pública (Tomo 24).

Martínez Vigil, Daniel, Siempre á ti (Tomo 19).

Martínez Vigil, Daniel, Símbolos (Tomo 20).

Melián Lanifur, Luis, El canto de la alondra (Tomo 19).

Montes, Victoriano E., El Tambor de San Martín (Tomo 19).

Muñoz, Daniel, La feria (Tomo 19).

Nin Frías, José, Pensamientos (Tomo 20).

Papini y Zas, Guzmán, A un cardenal (Tomo 24).

Pérez Petit, Víctor, Heroísmo (Tomo 24).

Pérez Petit, Víctor, Mi caballo (Tomo 24).

Pérez, Abel J., Artigas (Tomo 19).

Ramírez, Carlos María, Artigas (Tomo 19).

Ramírez, Carlos María, Grandeza é infortunios de Bolívar (Tomo 19).

Regules, Elías, Mi tapera (Tomo 19).

Reyles, Carlos, Vesania amorosa (Tomo 24).

Rodó, José Enrique, Ariel (Tomo 24).

Rodó, José Enrique, El espíritu de Goethe (Tomo 19).

Rodó, José Enrique, Los seis peregrinos (Tomo 20).

Roxlo, Carlos, Andresillo (Tomo 19).

Roxlo, Carlos, La trilla (Tomo 19).

Sánchez, Florencio, Nuestros hijos (Tomo 20).

Sánchez, Ricardo, Ante la tumba de un amigo (Tomo 24).

Sastre, Marcos, El viaje á las islas (Tomo 19).

Schinca, Francisco Alberto, ¡Evohé! (Tomo 24).

Sienra Carranza, José, Carta (Tomo 19).

Sierra Carranza, José M., A una paraguaya (Tomo 19).

Soca, Francisco, La juventud es la legión de la gloria (Tomo 24).

Thévenin, Leopoldo, En relación (Tomo 24).

Varela, José Pedro, Gobierno de la escuela (Tomo 24).

Vaz Ferreira, Carlos, Moral de periodistas (Tomo 24).

Vaz Ferreira, Carlos, Reacciones (Tomo 20).

Vaz Ferreira, María Eugenia, Invicta (Tomo 20).

Vaz Ferreira, María Eugenia, La viejecita (Tomo 20).

Zorrilla de San Martín, Juan, El mensaje de América (Tomo 19).

Zorrilla de San Martín, Juan, Los funerales de Tabaré (Tomo 19).

Zubillaga, Juan A., «Redención», novela de Ángel Estrada (Tomo 20).

Zum Felde, Alberto, El solitario llama (Tomo 20). 


\section{Los más editados}

Acuña de Figueroa, Francisco 7

Gómez, Juan Carlos, 3

Rodó, José Enrique, 3

Acevedo Díaz, Eduardo, 2

Vaz Ferreira, María Eugenia 2

Zorrilla de San Martín, Juan, 2

Roxlo, Carlos, 2

Vaz Ferreira, Carlos, 2

Ramírez, Carlos María, 2

Pérez Petit, Víctor, 2

Martínez Vigil, Carlos, 2

Martínez Vigil, Daniel, 2

Berro, Aurelio, 2

Bauzá, Francisco, 2

Sierra Carranza, José M., A una paraguaya (Tomo 19).

Sienra Carranza, José, Carta (Tomo 19).

\section{Con solo una aparición}

Agustini, Delmira

Becchi, Constantino

Bernández, Manuel

Berro, Adolfo

Blanco, Juan Carlos

Blixen, Samuel

Bustamante, Pedro

Castell, Adela

De Salterain, Joaquín

De Santiago, Ramón

De Vedia, Agustín

De Viana, Javier

Falco, Ángel

Fernández Medina

Floro Costa, Ángel

Fragueiro, Rafael

Frugoni, Emilio

Herrera y Obes, Julio

Herrera y Reissig, Julio

Hidalgo, Bartolomé 
Kubly, Enrique

Lamas, Andrés

Larrañaga, Dámaso Antonio

Maeso, Carlos M.

Magariños Cervantes

Melián Lanifur, Luis

Montes, Victoriano E.

Muñoz, Daniel

Nin Frías, José

Papini y Zas

Pérez, Abel J.

Regules, Elías

Reyles, Carlos

Sánchez, Florencio

Sánchez, Ricardo

Sastre, Marcos

Schinca, Francisco Alberto

Soca, Francisco

Thévenin, Leopoldo

Varela, José Pedro

Zubillaga, Juan A.

Zum Felde, Alberto 


\section{CATÁLOGO CUADERNOS DE LA ENCICLOPEDIA URUGUAYA}

Introducción I- El pensamiento de Artigas.

II- Horacio Quiroga. Cuentos de horror.

II- Benedetti, Hernández, Martínez Moreno, Onetti, Somers. Montevideo en cuentos.

1- Lozano, Azara, Larrañaga, Zorrilla de San Martín, Acevedo Díaz. Los indios del Plata.

2- Dámaso Antonio Larrañaga. Diario de Viaje a Paysandú.

3- Colón, Vespucio, Lópes de Sousa. Cartas del nuevo mundo.

4- La voz de los vencidos (textos indígenas).

5- Cardiel, González. Las vaquerías del mar.

6- Muerte al invasor (poemas y proclamas).

7- La poesía política (antología).

8- Pérez Castellano y otros. El nacimiento de la ciudad.

9- Rossi y otros. Cantos y bailes negros.

10- Las visitas extranjeras (antología).

11- José A. Wilde. Buenos Aires antes.

12- Artigas: El juicio de la historia. Antología de testimonios.

13- Paz, Iriarte, Dorrego. El pueblo en armas.

14- Julio Lerena Joanicó. Crónica de un hogar montevideano.

15- Eduardo Acevedo Díaz. Batallas contra imperios.

16- Juan C. Gómez, Francisco Bauzá. ¿Independencia, anexión, integración?

17- Carlos María Ramírez. La guerra civil y los partidos.

18- Alejandro Dumas. Montevideo o la nueva Troya.

19- Abdón Arózteguy. La revolución de las lanzas.

20- Berro, Magariños Cervantes y otros. Rimas y leyendas.

21- Agustín de Vedia. La barca Puig.

22- Angel Floro Costa. Panfletos como puñales.

23- José Pedro Varela. La democracia y la escuela.

24- Eduardo Gutiérrez, José J. Podestá. Juan Moreira.

25- Javier de Viana y otros. Cuentos camperos.

26- Florencio Sánchez. La gringa.

27- Las logias secretas. Selección documental.

28- Teófilo Díaz, Samuel Blixen, R. de las Carreras. Crónicas mundanas.

29- Francisco Piria. El socialismo triunfante.

30- Ernesto Herrera. El león ciego.

31- José E. Rodó. Ariel.

32- Rafael Barrett. La huelga y la cuestión social.

33- Julio Herrera y Reissig. Modernismo y poesía.

34- El pensamiento de Batlle.

35- Variaciones sobre el mismo tema.

36- José Pedro Bellán. La inglesita. 
37- ¿Virajes o continuidad?

38- La poesía femenina.

39- Carlos Vaz Ferreira. Moral para intelectuales.

40- Enrique Amorim. Del 1 al 6.

41- Juan Parra del Río. Polirritmos.

42- Crónicas de fútbol de El Hachero.

43- Cambalache. Antología de letras de tango.

44- J. A. Ramírez, J. Batlle, J. Serrato, M. C. Martínez, D. Arena, P. Blanco Acevedo. La doma del poder. 45- Joaquín Torres García. Unidad de la pintura.

46- Alfredo Mario Ferreiro. El hombre que se comió un autobus.

47- Francisco Espínola, Juan José Morosoli. Los mejores cuentos.

48- Juan Carlos Onetti. El pozo.

49- La voz de los estudiantes.

50- El pensamiento de Herrera.

51- Felisberto Hernández. Úrsula y otros cuentos.

52- Carlos Maggi. Mascarada.

53- La joven narrativa.

54- Punta del Este, 1961. John F. Kennedy- Ernesto Guevara.

55- Mario Benedetti. Poemas de la oficina y otros expedientes.

56- Carlos Quijano. «A rienda corta» y otros escritos.

57- La canción protesta.

58- Carlos Martínez Moreno. Cuentos de la ciudad.

59- El rico patrimonio de los orientales.

60- El rico patrimonio de los orientales. 


\section{CATÁLOGO DE LA BIBLIOTECA RODÓ}

Dirigida por Ovidio Fernández Ríos

Ediciones de obras de los mejores autores de nuestras letras, sin distinción de ideas ni tendencias.

1- Ariel.

José E. Rodó

Prólogo Leopoldo Alas

2- 1810 Poema dramático en tres actos y el milagro, poema en un acto.

Yamandú Rodríguez.

3- Versos Criollos.

Elías Regules

Prólogo Dr. J. Irureta Goyena

Semblanza: Eliseo Cantón

4- Fraile Aldao, poema dramático en 2 actos. Renacentista, poema en 1 acto. El Demonio de los Andes, poema en 1 acto.

Yamandú Rodríguez

5- Parábolas y otras lecturas.

José E. Rodó

6- Crónicas, discursos y conferencias. Páginas olvidadas.

Eduardo Acevedo Díaz.

Perfil: O. Fernández Ríos.

7-8- Motivos de Proteo.

José E. Rodó

9- Ensayos sobre marxismo.

Emilio Frugoni.

10- Teatro.

Florencio Sánchez.

11-12- Tabaré y La Leyenda Patria.

Juan Zorrilla de San Martín.

13-14- Clínica de niños.

Apuntes de clase tomados por el Dr. Dewet Barbato. 
Luis Morquio.

15- Eslabones.

Constancio Vigil.

16- Abrojos.

Javier de Viana.

17 a 20-Cuentos

Horacio Quiroga.

21-22- Los tres gauchos orientales.

Antonio D. Lussich.

23- Cuentos de la selva (para niños)

Horacio Quiroga.

24-26- Rodó. Su vida. Su obra.

Víctor Pérez Petit.

27- Batlle y el proceso histórico histórico del Uruguay.

Francisco Pintos.

28-29- Artículos de costumbres.

Mariano José de Larra.

30-31- Grito de Gloria.

Eduardo Acevedo Díaz.

32- La colina de los vaticinios.

Mario Falcao Espalter.

33- Nuevas opiniones literarias.

Alberto Lasplaces.

34-35- El mirador de Próspero.

José E. Rodó

36-37- Hombres de América

José E. Rodó

38-39- Poemas 
Walt Whitman

Traducidos por Armando Vasseur.

Estudio de Angel Guerra.

40- Generaciones

Alfredo Lepro

41-42- Batlle y los problemas sociales en Uruguay.

Domingo Arena.

43- Cuadros criollos y escenas de la dictadura de Latorre.

Domingo Arena.

44-45- Caramurú

Alejandro Magariños Cervantes

46-47- Poesías

Delmira Agustini

48-50- Vida y obra de Horacio Quiroga.

José M. Delgado, Alberto J. Brignole.

51-52- Miel amarga

Dr. Borges, Elsa Fernández

53-54- Paráfrasis

Roberto Sienra

55- Cuentos (tomo V)

Horacio Quiroga

56- Cuentos (tomo VI)

Horacio Quiroga

57-58- El camino de Paros

José E. Rodó

59-60- Academias, Cuentos y Ensayos

Carlos Reyles

61- Los perseguidos y otros cuentos (tomo VII) 
Horacio Quiroga

62-63- El error del Profesor Bodhel

Raúl E. Beathgen

64- Hermano de Bronce

Angel Falco

65-66- Teatro

Ismael Cortinas

67-68- Barro y sol

Serafín García

69-70- El que vendrá

José E. Rodó

71-72- Sobre el recado

Javier de Viana

73- Forastero...

E. Trías du Pré

74-75- Estudios literarios y filosóficos

Alejandro Arias

76-78- Juan María

J. M. Delgado

79-80- Poesías

O. Fernández Ríos

81-82- Las mujeres de Shakespeare

Luis Melián Lafinur

83- Pasado Amor

Horacio Quiroga

84- El crimen del otro y otros cuentos Horacio Quiroga 
85-87- Pompeyo Amargo (Novela)

Dionisio Trillo Pais

88- Cuentos (tomo IX)

Horacio Quiroga

89-90- Emociones Montevideanas

Orestes Baroffio

91-92- Cuentos (tomo X)

Horacio Quiroga

93- Arrecifes de Coral

Horacio Quiroga

94-97- Imágenes y Sugestiones

Francisco Ruqui

98-99- Abajo se vive mal

A. Tejera

100- Historia de un amor turbio

Horacio Quiroga

101-104- Lanza y Sable

Eduardo Acevedo Díaz

105- La carreta

O. Fernández Ríos

106-107- Antología del cuento uruguayo (tomo I)

Alberto Lasplaces

108-109- Antología del cuento uruguayo (tomo II)

Alberto Lasplaces

110-111- Epístolas. Psalmos y otros poemas

Roberto de las Carreras

112-113- Crónica de la Revolución del Quebracho Javier de Viana 
114-116- Nuevo mosaico Poético

Francisco Acuña de Figueroa

117- Hombres y mujeres (cuentos)

J. P. Morosoli

118- Poemas Civiles

Emilio Frugoni

119-120- José Enrique Rodó. Su personalidad y su obra.

Gonzalo Zaldumbide

121-122- Zarzas

Dionisio Trillo Pais

123-124- Burbujas

Serafin García

125-127- Historia de la literatura gauchesca en Uruguay

Domingo A. Caillava

128-129- Más allá y otros cuentos

Horacio Quiroga

130-131- Cuento terciario y otros cuentos

Horacio Quiroga

132-133- Idilio y otros cuentos (tomo XII)

Horacio Quiroga

134-135- Filosofía preuniversitaria en el Uruguay

Arturo Ardao

136-137- Campo

Javier de Viana

138-139- Leyendas del Terruño

Juan Carlos Pedemonte

140-142- Gurí y otras novelas 
Javier de Viana

143-145- Lauracha

Otto Miguel Cione

Gaucha

Javier de Viana

Totales:

Rodó 12 vol.

Quiroga 22 vol. 


\section{CAPÍTULO ORIENTAL}

1- La patria vieja (antología)

Eduardo Acevedo Díaz

2- La novia robada y otros cuentos

Juan Carlos Onetti

3- Montevideanos

Mario Benedetti

4- El país de los orientales

Antonio Dámaso Larrañaga

J. P. Robertson

F. de Azara

J. M. Pérez Castellano

F. de Azara

J. B. de Puente

J. M. Salazar

5- De las «Toraidas» al «Tabaré» (antología)

6- Ismael

Eduardo Acevedo Díaz

7- Selección de prosa

Juan Zorrilla de San Martín

8- El Uruguay y sus problemas en el siglo XIX (antología)

Andrés Lamas

Bernardo P. Berro

Juan Carlos Gómez

Gómez y Pedro Bustamante

Domingo Ordoñana

José Pedro Varela

Carlos María Ramírez

Francisco Bauzá 
Angel Floro Costa

Juan Carlos Blanco

Julio Herrera y Obes

9- El viejo tiempo: cronistas y memoralistas

Ramón de Cáceres

General Ventura Rodríguez

Orlando Ribero

León de Palleja

Luis Ponce de León

Isidoro de María

Antonio N. Pereira

Daniel Muñoz

Mariano B. Berro

Pedro Erasmo Callorda

Luis Suárez

Emilio Oribe

10- La poesía gauchesca

11- El color del 900

Víctor Pérez Petit

Julio Herrera y Reissig

Carlos Reyles

Josefina L. A. de Blizin

Alberto Zum Felde

Florencio Sánchez

Emir Rodríguez Monegal

Federico Ferrando

Horacio Quiroga

Ernesto Mario Barreda

César Miranda

Juan Mas y Pí

Alberto Zum Felde

César Miranda

Roberto de las Carreras

Herrera y Reissig y de las Carreras

Pedro Manini Ríos 
Adalberto Solf

José Bianco

12- El camino de Paros (viajes)

José Enrique Rodó

13- Antología

Herrera y Reissig

14- Los Cálices Vacíos y La isla de los Cánticos

Delmira Agustini y María Eugenia Vaz Ferreira

15- Barranca abajo y En familia

Florencio Sánchez

16- La raza de Caín

Carlos Reyles

17- A la deriva y otros relatos

Horacio Quiroga

18- Los mejores cuentos de

Javier de Viana

19- Crónica de un crimen

Justino Zavala Muniz

20- Las lenguas de diamante

Juana de Ibarbourou

21- La poesía de los años veinte (antología) Ida Vitale selecciona

22- Fermentario

Carlos Vaz Ferreira

23- Poemas Nativos y romances

24- Los poetas del centenario

25- Tierra y tiempo

juan José Morosoli 
26- Don Juan el Zorro (fragmentos)

Francisco Espínola

27- La desembocadura

Enrique Amorim

28- Las máscaras del amor

Juan Carlos Onetti

29- El cocodrilo y otros cuentos

Felisberto Hernández

30- Humoristas y cronistas (antología)

31- Las llamadas y otras obras

Carlos Maggi

32- La poesía del 45 (antología)

Orfilia Bardesio

Mario Benedetti

Amandra Berenguer

Carlos Brandy

Sarandy Cabrera

Humberto Megget

Ricardo Paseyro

Idea Vilariño

Ida Vitale

33- Los fuegos de San Telmo

José Pedro Díaz

34- La sirena y otros cuentos

Carlos Martínez Moreno

35- La crítica del 45 (antología)

Emir Rodríguez Monegal

Mario Benedetti

Carlos Real de Azúa 
Domingo L. Bordoli

Arturo Sergio Visca

José Pedro Díaz

Ángel Rama

Carlos Martínez Moreno

Hugo R. Alfaro

H. Alsina Thevenet

Mauricio Müller

José Carlos Álvarez

Antonio Larreta

36- El Uruguay visto por los uruguayos (I) selección por Carlos Real de Azúa

Reyes Abadie, Bruschera y Melogno

Esteban Campal

Vivián Trías

Reyes Abadie

Washington Lockhart

Oscar H. Bruschera

Roberto Ares Pons

Carlos Machado

Lucía Sala, Rodríguez y de la Torre

Anibal Barrios Pintos

Barrán y Nahum

Gustavo Beyhaut

Guillermo Vázquez Franco

Juan Antonio Oddone

Blanca París

Reyes Abadie

Ricardo Martínez Ces

37- El Uruguay visto por los uruguayos (II) selección

38- La nueva narrativa (antología)

L. S. Garini

Anderssen Banchero

Jorge Musto

Mario César Fernández

Juan Carlos Somma 
Jorge Onetti

Alberto Paganini

Jesús C. Guiral

Silvia Lago

Hiber Conteris

Gley Eyherabide

Jorge Sclavo

Fernando Ainsa

Eduardo Galeano

Teresa Porsekansky

39- La nueva poesía (antología)

40- Políticos y románticos

Raúl Montero Bustamante

41- Lo aparente y lo concreto del arte Joaquín Torres García

42- El fútbol (antología)

43- El tango (antología)

44- Los cantos de Maldoror (antología)

Lautréamont 
ESQUEMA DE PIVEL Y SUS REDES INTELECTUALES

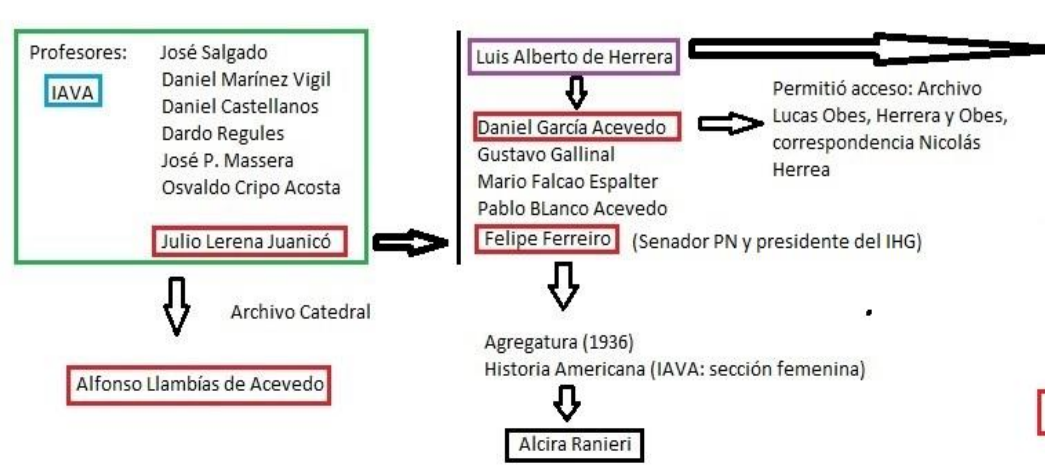

Ejercito
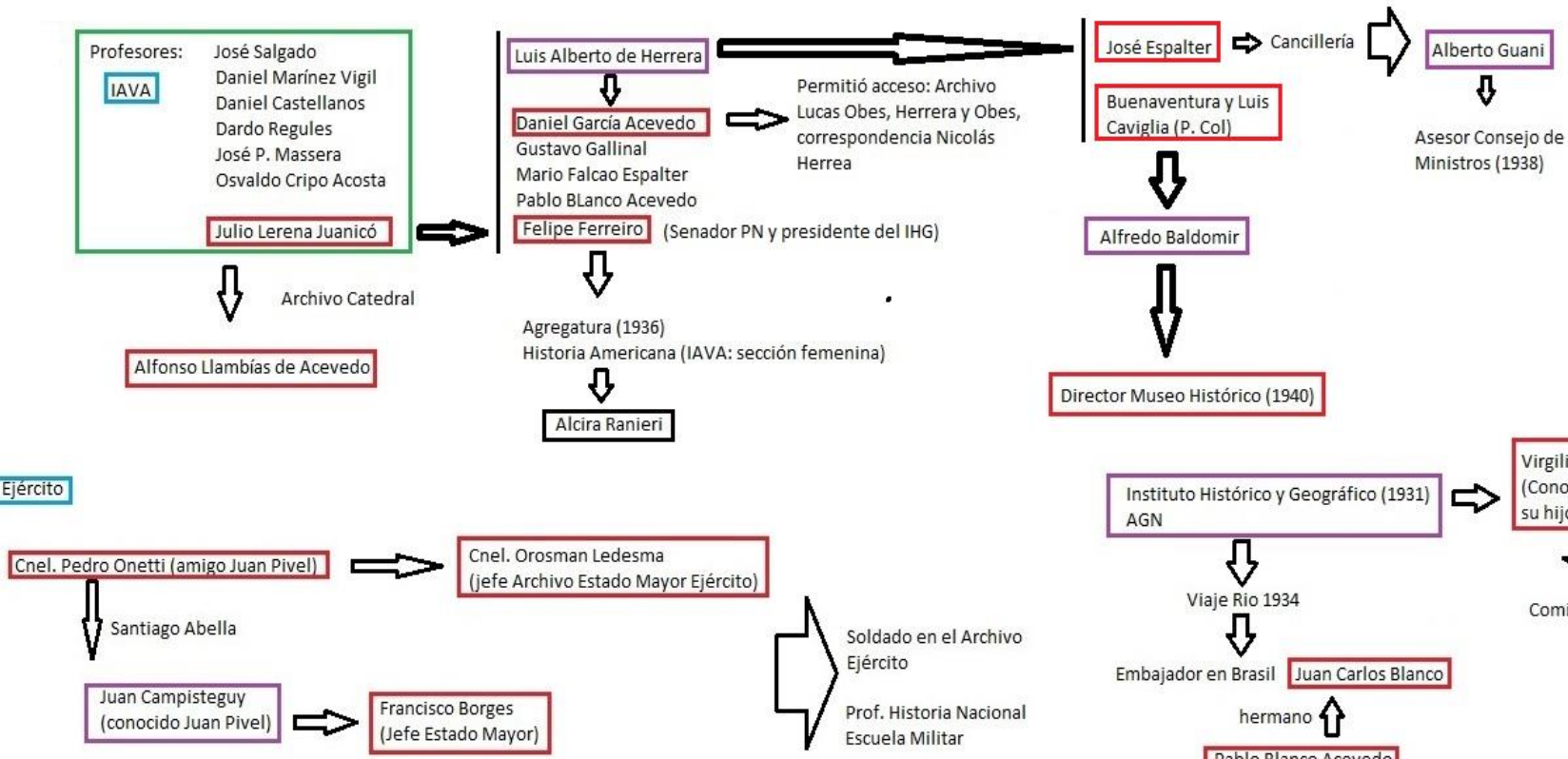

Director Museo Histórico (1940)

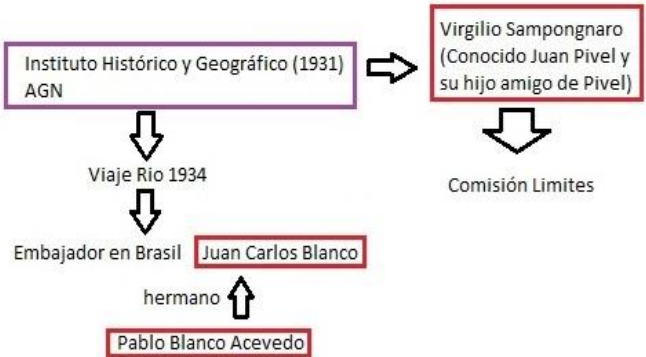

Religioso

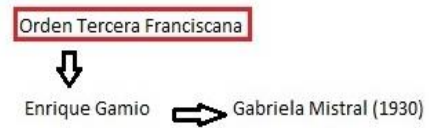

TOMOS DE LA COLECCIÓN... IMPRESOS POR AÑO

En el gráfico pueden verse las distintas etapas que debidamente señalé y demostré en mi tesis: la «génesis colorada» (1953-1959), los «años dorados», durante la estancia de Pivel en el Ministerio de Instrucción Pública y Seguridad Social (1963-1967), en la tercera etapa, encontramos un «estancamiento y decadencia» (1968-1982), para finalizar con el freno en la edición, establecido sobre todo durante la dictadura cívico-militar (1973-1985).

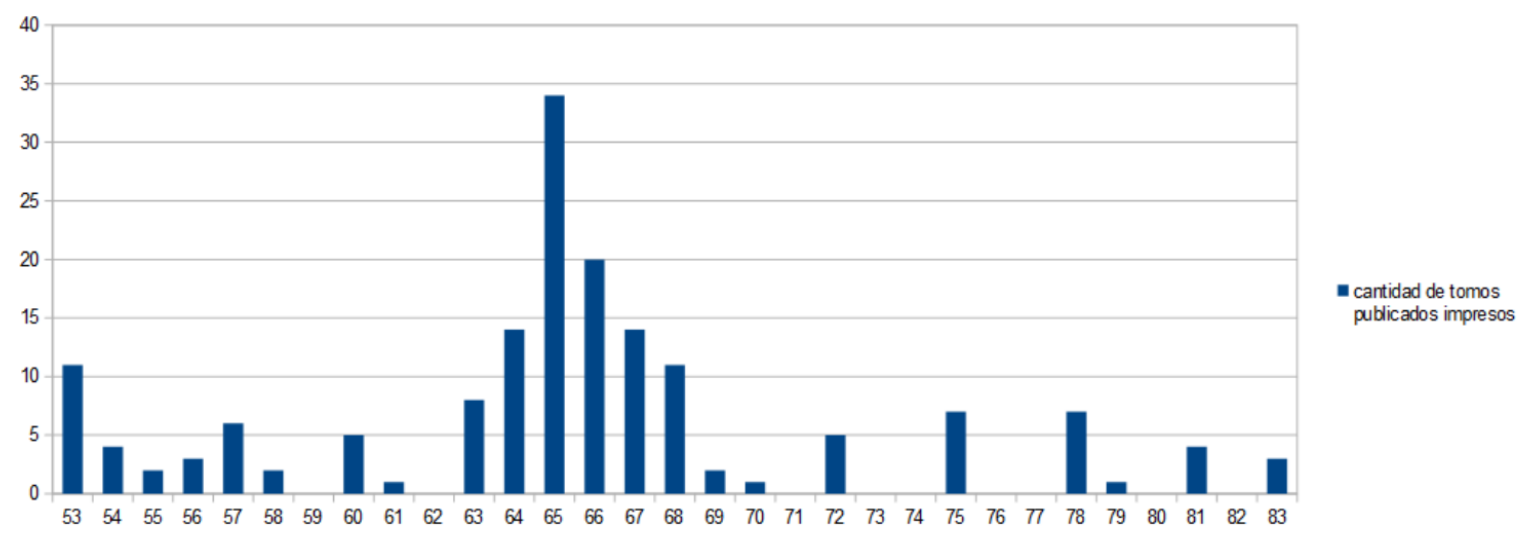




\section{BIBLIOGRAFÍA}

\section{Fuentes primarias}

Colección de clásicos uruguayos "Biblioteca Artigas" (1953- 1982). Montevideo, Ministerio de Instrucción Pública y Previsión Social.

Revista Histórica, segunda época (1942-1982), Museo Histórico Nacional.

\section{Fuentes inéditas}

Archivo General de la Nación del Uruguay. Ministerio de Justicia, Culto e Instrucción Pública (1883- 1891).

------. Universidad de la República (1827- 1953).

------. Juan E. Pivel Devoto (1770- 1997).

Archivo de la Biblioteca Nacional del Uruguay.

Biblioteca Personal Pivel Devoto, Montevideo, Universidad de Montevideo.

\section{Publicaciones periódicas}

Semanario Marcha (1939- 1974). Montevideo.

Revista Clinamen (1947-1948). Montevideo, El Siglo Ilustrado.

Revista Asir (1948-1959). Mercedes, Ceibo.

Revista Número (1949-1955; 1963- 1964). Montevideo, Rosgal (1era época), Emecé (2da época).

Revista Nexo (1955-1958). Montevideo, Hispano uruguaya de artes gráficas.

Entregas de la Licorne (1947-1948; 1953-1961). París y Montevideo, Uruguaya.

Revista Capitulo Oriental (1968-1969). Montevideo, Centro Editor de América Latina.

La Enciclopedia Uruguaya (1968-1970). Montevideo.

\section{BIBLIOGRAFÍA GENERAL}

AA. VV (1975). La independencia nacional. Montevideo: Ministerio de Educación y Cultura, Colección de Clásicos Uruguayos. 
AA.VV. (1997). Diccionario Akal de términos literarios, Madrid, Akal.

AA. VV. (1972). Una política nacional del libro. Montevideo: Comunidad Sur, Biblioteca Nacional.

AA.VV. (2021). Una aproximación a la historia de la edición en Uruguay [En prensa]. Madrid: EDI-RED.

ABRAHAM, C. (2016). La editorial Tor: Medio siglo de libros populares. Temperley: Tren en Movimiento.

ACEVEDO, E. (1933). Anales Históricos del Uruguay, tomos I, II, III, IV y V. Montevideo: Barreiro y Ramos.

(1985). Poesía y sociedad (Uruguay 1881-1991). Montevideo: Arca.

(1994a). La Balsa de la Medusa. Ensayos sobre identidad, cultura y fin de siglo en Uruguay. Montevideo: Ediciones Trilce.

(1994b). La biblioteca en ruinas. Reflexiones culturales desde la periferia.

Montevideo: Ediciones Trilce.

ACHUGAR, H. (Comp.) (1998). La fundación por la palabra. Letra y nación en América Latina en el siglo XIX. Montevideo: FHCE, Universidad de la República.

y CAETANO, G. (Comp.) (1993). Identidad uruguaya: ¿mito, crisis o afirmación? Montevideo: Ediciones Trilce.

ACREE, W. (2013). La lectura cotidiana. Cultura impresa e identidad colectiva en el Río de la Plata, 1780-1910. Buenos Aires: Prometeo.

AÍNSA, F. (2002). Del canon a la periferia. Encuentros y transgresiones en la literatura uruguaya. Montevideo: Ediciones Trilce.

— (2003). Reescribir el pasado. Mérida: Ediciones El otro, el mismo.

(2008). Espacios de la memoria. Lugares y paisajes de la cultura uruguaya.

Montevideo: Ediciones Trilce.

(2011). Confluencias en la diversidad: siete ensayos sobre la inteligencia creadora uruguaya. Montevideo: Ediciones Trilce.

ALFARO, H. (1984). Navegar es necesario: Quijano y el semanario Marcha. Montevideo: Ediciones de la Banda Oriental.

ALONSO, R. y DEMASI, C. (1986). Uruguay 1958-1968. Crisis y estancamiento. Montevideo: Ediciones de la Banda Oriental.

ALSINA THEVENET, H. y ROCCA, P. (1994). La obra crítica de Emir Rodríguez Monegal. Montevideo: Ediciones de la Banda Oriental.

ALTAMIRANO, C. (2013). Intelectuales, notas de investigación sobre una tribu inquieta. Buenos Aires: Siglo XXI. 
(2008). Historia de los intelectuales en América Latina, 2 tomos. Buenos

Aires: Katz.

AMENGUAL, C. (2012). Rara Avis. Montevideo: Taurus.

ANDERSON, B. (2011). Comunidades imaginadas. Reflexiones sobre el origen y la difusión el nacionalismo. Ciudad de México: Fondo de Cultura Económica.

ANDERSON IMBERT, E. (1987). Historia de la literatura latinoamericana, 2 tomos. Ciudad de México: Fondo de Cultura Ecónomica.

ANGENOT, M. (2010). El discurso social. Buenos Aires: Siglo XXI. y otros. (2002). Teoría literaria, México, Siglo XXI.

ANTEQUERA, J. Á. (2004). Ángel Rama y la Biblioteca Ayacucho: Aporte fundamental a la autonomía y la integración cultural latinoamericana. Voz y Escritura. Revista de Estudios Literarios, (14).

BARBIER, F. (2015a). Historia del libro. Madrid: Alianza Editorial. (2015b). Historia de las bibliotecas. De Alejandría a las bibliotecas virtuales. Buenos Aires: Ampersand.

BARBOZA BORGES, A. (2013). La marginalidad canonizada y el caso Leo Maslíah. Montevideo: Antítesis.

BARRÁN, J. P. (1989). Historia de la sensibilidad en el Uruguay. Montevideo: Ediciones de la Banda Oriental.

(2010). Epílogos y legados. Escritos inéditos, Testimonios.Montevideo: Ediciones de la Banda Oriental.

y NAHUM, B. (1994). Historia social de las revoluciones de 1897 y 1904. Montevideo: Ediciones de la Banda Oriental.

BARTHES, R. (2003). El grado cero de la escritura y otros ensayos críticos. Buenos Aires: Siglo XXI.

(2013). Variaciones de la escritura. Buenos Aires: Paidós.

BAUZÁ, F. (1965). Historia de la Dominación Española en el Uruguay, Tomo I (segunda parte). Montevideo: Ministerio de Instrucción Pública y Seguridad Social, Colección de Clásicos Uruguayos.

BENEDETTI, M. (1966). El país de la cola de paja. Montevideo: Arca. (1997). Literatura uruguaya siglo XX. Montevideo: Seix Barral.

BENÍTEZ, H. (1997). Poetas uruguayos de los '60. Montevideo: Ediciones Rosgal. (2000). Interpretación y eclipse: ensayos sobre literatura uruguaya (Lautréamont, Julio Herrera y Reissig, Felisberto Hernández, Juan Carlos Onetti y Marosa di Giorgio). Montevideo: Linardi y Risso. 
BENTANCUR, A. (1997). El puerto colonial de Montevideo (2 vol.). Montevideo: Facultad de Humanidades y Ciencias de la Educación. (2011). La familia en el Río de la Plata a fines del período hispánico: historias de la sociedad montevideana. Montevideo: Planeta.

BENVENUTO, L. y otros. (1971). Uruguay hoy. Buenos Aires: Siglo XXI.

BERAZA, A. (1967). El pueblo reunido y armado. Montevideo: Ediciones de la Banda Oriental.

BHABHA, H. K. (Comp.) (2010). Nación y narración. Buenos Aires: Siglo XXI.

BLOOM, H. (2012). El canon occidental. La escuela y los libros de todas las épocas. Barcelona: Anagrama.

BOSCHETTI, A. (1985). Sartre et «Les Temps modernes». París: Minuit.

BOURDIEU, P. (1995). Las reglas del arte. Génesis y estructura del campo literario. Barcelona: Anagrama. (1999). Intelectuales, política y poder. Buenos Aires: Eudeba.

(2002). Campo de poder, campo intelectual. Buenos Aires: Montressor. (2013). El sentido social del gusto. Buenos Aires: Siglo XXI.

BRALICH, J. (1990). Los textos escolares como instrumento ideológico. Montevideo: Universidad de la República.

BRANDO, Ó. (2002). La generación del 45: una mirada desde la literatura. Montevideo: Editorial Técnica.

BRAVO, L. (2007). Escrituras visionarias: ensayos sobre literaturas iberoamericanas. Montevideo: Fin de Siglo.

(2012). Voz y palabra. Historia transversal de la poesía uruguaya 19501973. Montevideo: Estuario Editorial.

BROQUETAS, M. (2014). La trama autoritaria. Derechas y violencia en Uruguay (1958-1966). Montevideo: Ediciones de la Banda Oriental.

BULA PÍRIZ, R. (1964). Delmira Agustini. Montevideo: s/e.

BUONOCORE, D. (1994). Libreros, editores e impresores de Buenos Aires. Buenos Aires: El Ateneo.

BURKE, P. (1995). Los avatares de El cortesano. Lecturas y lectores de un texto clave del espíritu renacentista. Barcelona: Gedisa Editorial.

(2001). Formas de hacer historia. Madrid: Alianza Editorial. (2010). ¿Qué es la historia cultural? Barcelona: Paidós.

CABELLO, A. y otros (2011). En los márgenes del canon. Aproximaciones a la literatura popular y de masas escrita en español (siglos XX y XXI). Madrid: CSIC. 
CAETANO, G. (dir.) (2000). Los uruguayos del Centenario. Nación, ciudadanía, religión y educación (1910-1930). Asunción: Taurus.

y ALFARO, M. (1995). Historia del Uruguay contemporáneo. Materiales para el debate. Montevideo: Fundación de Cultura Universitaria-ICP, Universidad de la República.

CAETANO, G. y RILLA, J. (1999). Historia contemporánea del Uruguay. De la colonia al Mercorsur. Montevideo: Fin de Siglo.

(2011). Breve historia de la dictadura. Montevideo: Ediciones de la Banda Oriental.

CAMPODÓNICO, M. Á. (2007). Diccionario de la cultura uruguaya. Montevideo: Linardi y Risso.

CASAL, J. (1940). Exposición de la poesía uruguaya: desde sus orígenes hasta 1940. Montevideo: Claridad.

CASTELlANOS, A. (1971). Historia del desarrollo edilicio y urbanístico de Montevideo (1829-1914). Montevideo: Junta Departamental de Montevideo.

CASTRO, J. (1965, 3 de setiembre). «El libro al alcance de todos», Marcha, Montevideo.

CATTARUZZA, A. (Dir.) (2001). Nueva Historia Argentina. Tomo VII: Crisis económica, avance del estado e incertidumbre política (1930- 1943). Buenos Aires: Sudamericana.

CAVAlLO, G. y CHARTIER, R (Comps.) (1998). Historia de la lectura en el mundo occidental. Madrid: Taurus.

CELLA, S. (1998). Canon y otras cuestiones. En: CELLA, S. (Comp.). Dominios de la literatura. Acerca del canon. Buenos Aires: Losada.

CHARTIER, R. (1994). El orden de los libros. Lectores, autores, bibliotecas en Europa entre los siglos XIV y XVIII. Barcelona: Gedisa.

(1999). Cultura escrita, literatura e historia. Ciudad de México: Fondo de Cultura Económica.

(2000). El juego de las reglas: lecturas. Buenos Aires: Fondo de Cultura

Económica.

(2005). El mundo como representación. Barcelona: Gedisa.

(2006a). Inscribir y borrar. Cultura escrita y literatura (siglos XI-XVIII),

Buenos Aires: Katz.

(2006b). ¿Qué es un texto? Madrid: Círculo de Bellas Artes.

(2008). Escuchar a los muertos con los ojos. Buenos Aires: Katz. 
COSSE, R. (2008). Tradición y cambio en la narrativa uruguaya: Levrero, Onetti, Zorrilla de San Martín, Acevedo Díaz, Rodó, Dossetti. Montevideo: Linardi y Risso.

COSSE, I. y MARKARIAN, V. (1996). 1975: año de la orientalidad. Identidad, memoria e historia de una dictadura. Montevideo: Trilce.

D’ELIA, G. (1986). El Uruguay neobatllista. Montevideo: Ediciones de la Banda Oriental.

DALMARONI, M. (2006). Una república de las letras: Lugones, Rojas, Payró: escritores argentinos y Estado. Rosario: Beatriz Viterbo.

DARNTON, R. (1999). La gran matanza de gatos y otros episodios de la historia cultural francesa. Ciudad de México: Fondo de Cultura Económica.

(2008). Los best-sellers prohibidos en Francia antes de la revolución.

Buenos Aires: Fondo de Cultura Económica.

(2010). El beso de Lamourette: Reflexiones sobre historia cultural. Buenos Aires: Fondo de Cultura Económica.

(2014). Censores trabajando. De cómo los Estados dieron forma a la literatura. Ciudad de México: Fondo de Cultura Económica.

DE ARMAS, G. y GARCÉ, A. (1997). Uruguay y su conciencia crítica. Intelectuales y política en el siglo XX. Montevideo: Ediciones Trilce.

DE CÁCERES, E. (1965). Prólogo. En: Agustini, D. Antología. Montevideo: Ministerio de Instrucción Pública y Previsión Social, Colección de Clásicos Uruguayos.

DE DIEGO, J. L. (2014). Editores y políticas editoriales en Argentina (1880-2010). Buenos Aires: Fondo de Cultura Económica.

(2015). La otra cara de Jano: una mirada crítica sobre el libro y la edición.

Buenos Aires: Ampersand.

(2017). «Semblanza de José Boris Spivacow (1915- 1994)». En: Biblioteca Virtual Miguel de Cervantes - Portal Editores y Editoriales Iberoamericanos (siglos XIX-XXI). EDI-RED: http://www.cervantesvirtual.com/obra/jose-boris-spivacow-buenos-aires19151994-semblanza-777066/

(2019). Los autores no escriben libros. Nuevos aportes a la historia de la edición. Buenos Aires: Ampersand.

DE MATTOS, T. (1988). ¡Bernabé!, ¡Bernabé! Montevideo: Ediciones de la Banda Oriental.

DEGIOVANNI, F. (2007). Los textos de la patria. Nacionalismo, políticas culturales y canon en Argentina. Rosario: Beatriz Viterbo. 
(2015). La invención de los clásicos: nacionalismo, filología y políticas

culturales en Argentina. Orbis Tertius, $10 \quad$ (11). Recuperado de https://www.olivar.fahce.unlp.edu.ar/index.php/OT/article/view/OTv10n11d04

DELGADO, V. y ESPÓSITO, F. (2014). «1920-1937: La emergencia del sector editor moderno». En: DE DIEGO, J. L. Editores y políticas editoriales en Argentina (1880-2010). Buenos Aires: Fondo de Cultura Económica.

DEMASI, C. y otros (2009). La dictadura civico-militar. Uruguay 1973-1985. Montevideo: Ediciones de la Banda Oriental.

DERRIDA, J. (1997). La diseminación. Madrid: Editorial Fundamentos.

DEVÉS VALDÉS, E. (2007). Redes intelectuales en América Latina. Hacia la constitución de una comunidad intelectual. Santiago de Chile: Universidad de Chile.

DUJOVNE, A. (2014). Una historia del libro judio. La cultura judía argentina a través de sus editoriales, libreros, traductores, imprentas y bibliotecas. Buenos Aires: Siglo XXI.

EAGLETON, T. (1999). La función de la crítica. Barcelona: Paidós. (2004). Una introducción a la teoría literaria. Ciudad de México: Fondo de Cultura Económica.

ECO, H. (1992). Obra abierta. Buenos Aires: Planeta.

ESCARPIT, Robert (1968). La revolución del libro, Madrid, Alianza Editorial.

ESPECHE, X. (2010). Marcha del Uruguay hacia América Latina por el Río de la Plata. En: ALTAMIRANO, C. (Dir.). Historia de los intelectuales en América Latina. Buenos Aires: Katz.

(2016). La paradoja uruguaya. Intelectuales, latinoamericanismo y nación a mediados del siglo XX. Bernal: Universidad Nacional de Quilmes.

ESPIGA, S. (2015). La infancia normalizada. Libros, maestros e higienistas en la escuela pública uruguaya 1885-1918. Montevideo: Antítesis Editorial.

EVEN-ZOHAR, I. (1990). Polysystem Theory. Poetics Today, 11, 9-26. Traducción de Ricardo Bermudez Otero, versión digital en internet: http://www.tau.ac.il/ itamarez/works/papers/trabajos/EZ-teoria-polisistemas.pdf

FERNÁNDEZ, A. y VILLA, Ó. (2012). Bibliotecas coloniales. Libros, lecturas y bibliotecas en la América Española y la Banda Oriental durante el período colonial. Montevideo: Ediciones de la Banda Oriental.

FERNÁNDEZ MORENO, C. (Coord.) (1998). América Latina en su literatura. Ciudad de México: Siglo XXI.

FERNÁNDEZ Y MEDINA, B. (1918). Librería Nacional A. Barreiro y Ramos. Montevideo: Barreiro y Ramos. 
FEVBRE, L. y MARTIN, H.-J. (1958/2005). La aparición del libro. Ciudad de México: Fondo de Cultura Económica.

FINCH, H. (1980). Historia económica del Uruguay contemporáneo. Montevideo: Ediciones de la Banda Oriental.

(2005). La economía política del Uruguay contemporáneo: 1870-2000. Montevideo: Ediciones de la Banda Oriental.

FINKELSTEIN, D. y McCLEERY, A. (2014). Una introducción a la historia del libro. Buenos Aires: Paidós.

FISHER, D (2013). Serás mía o de nadie. La verdadera muerte de Delmira Agustini. Montevideo: Sudamericana.

FOUCAULT, M. (1990). Historia de la locura en la época clásica. Ciudad de México: Fondo de Cultura Económica.

(2007). La arqueología del saber, Buenos Aires: Fondo de Cultura Económica.

(2008). La verdad y las formas jurídicas. Buenos Aires: Gedisa.

- (2010a). Defender la sociedad. Buenos Aires: Fondo de Cultura Económica. (2010b). Las palabras y las cosas, Buenos Aires, Siglo XXI.

FREGA, A y otros (2008). Historia del Uruguay en el siglo XX (1890-2005). Montevideo: Ediciones de la Banda Oriental.

GARCÍA BERISSO, N. (1956). «Evocando a Claudio García», en: El Fogón, año J, n 1 , Montevideo.

GATES, H. L. (1998). Las obras del amo: sobre la formación del canon y la tradición afroamericana. En: SULLÁ, E. El canon literario. Madrid: Arco/Libros.

GENETTE, G. (1967). Estructuralismo y crítica literaria. Córdoba: Universitaria. (1989). Figuras III. Barcelona: Lúmen. (1989). Palimpsestos. La literatura en segundo grado. Madrid: Taurus. (2001). Umbrales. Buenos Aires: Siglo XXI.

GILMAN, C. (2012). Entre la pluma y el fusil: debates y dilemas del escritor revolucionario en América Latina, Buenos Aires, Siglo XXI.

GINZBURG, C. (1994). El queso y los gusanos. Madrid: Muchnik Editorial. (2008). Mitos, emblemas, indicios. Barcelona: Gedisa. (2010). El hilo y las huellas: lo verdadero, lo falso, lo ficticio. Buenos Aires: Fondo de Cultura Económica. 
GIORDANO, L. (1931). María Elena Muñoz. En: REYLES, C. Historia sintética de la literatura uruguaya: plan aprobado por la comisión nacional del centenario. Montevideo: Alfredo Vila.

GIULIANI, A. (2018). Editores y política: entre el mercado latinoamericano de libros y el primer peronismo: 1938-1955. Temperley: Tren en Movimiento.

GOCIOL, J. (2010). Boris Spivacow. El señor editor de América Latina. Buenos Aires: Capital Intelectual.

GUTIÉRREZ, N. (2013a). República Oriental de las Letras. La Colección de Clásicos Uruguayos como política cultural del Estado (1950- 1967). Tesis de maestría. Montevideo: Universidad de Montevideo [inédita].

(2013b). La formación de los lectores críticos según los programas de literatura de 1957. En: DELIO, L. (Comp.). Estudios en Historia de la Educación: algunas políticas, prácticas, ideas. Vol. I. Montevideo: ANEP-CFE.

(2017a) «Semblanza de la Colección de Clásicos Uruguayos (1953- )». En: Biblioteca Virtual Miguel de Cervantes - Portal Editores y Editoriales Iberoamericanos (siglos XIX-XXI). EDI-RED: http://www.cervantesvirtual.com/obra/coleccion-declasicos-uruguayosmontevideo-1953--semblanza-848964/

(2017b). «Semblanza de Juan Ernesto Pivel Devoto (1910-1997)». En Biblioteca Virtual Miguel de Cervantes - Portal Editores y Editoriales Iberoamericanos (siglos XIX-XXI). EDI-RED: http://www.cervantesvirtual.com/obra/juan-ernesto-piveldevotopayusandu-1910--montevideo-1997-semblanza-788502/

HARRIS, W. (1998). La canonicidad. En: SULLÁ, E. El canon literario. Madrid: Arco/Libros.

HOBSBAWM, E. (1998). Naciones y nacionalismo desde 1780. Barcelona: Crítica.

ISER, W. (1987). El proceso de lectura: Enfoque fenomenológico. En: VV. AA. Estética de la recepción. Madrid: Arco/Libros.

JABLONKA, I. (2016). La historia es una literatura contemporánea: manifiesto por las ciencias sociales. Buenos Aires: Fondo de Cultura Económica.

JITRIK, N. (1998). Canónica, regulatoria y transgresiva. En: CELLA, S. (Comp.). Dominios de la literatura. Acerca del canon. Buenos Aires: Losada.

JURT, J. (2014). Naciones literarias. Una sociología histórica del campo literario. Villa María: Eduvim.

KERMODE, F. (1998). El control institucional de la interpretación. En: SULLÁ, E. El canon literario. Madrid: Arco/Libros. 
KUSCHNER, E. (2002). Articulación histórica de la literatura. En: ANGENOT, M. y otros. Teoría literaria. México: Siglo XXI.

LABROUSSE, A. (2009). Una historia de los tupamaros: de Sendic a Mujica. Montevideo: Editorial Fin de Siglo.

LESSA, A. (2010). La revolución imposible. Los Tupamaros y el fracaso de la vía armada en el Uruguay del siglo XX. Montevideo: Editorial Sudamericana.

LYONS, M. (2012). Historia de la lectura y de la escritura en el mundo occidental. Buenos Aires: Editoras del Calderón.

(2016). La cultura escrita de la gente común en Europa, c. 1860-1920.

Buenos Aires: Ampersand.

MAGGI, C. (1968). Sociedad y cultura en el presente. En: Capítulo Oriental. Montevideo: Centro Editor de América Latina, Fasc. 3.

MANGUEL, A. (2014). Una historia de la lectura. Buenos Aires: Siglo XXI .

MAILHE, A. (2016). La colección «Humanior» y la formación de un lectorado americanista. En: II Coloquio Argentino de Estudios sobre el Libro y la Edición. Córdona: Conicet-UNC.

MARCHESE, A. y FORRADELLAS, J. (2006). Diccionario de retórica, crítica y terminología literaria. Barcelona: Ariel.

MARCHESI, A. (2019). Hacer la revolución. Guerrillas latinoamericanas, de los años sesenta a la caída del Muro. Buenos Aires: Siglo XXI.

(2009). "Una parte del pueblo uruguayo feliz, contento, alegre". Los caminos culturales del consenso autoritario durante la dictadura. En: DEMASI, C. y otros. La dictadura civico-militar. Uruguay 1973-1985. Montevideo: Ediciones de la Banda Oriental.

MARÍAS, J. (1967). El método histórico de las generaciones. Madrid: Revista Occidente.

MAUNÁS, D. (1995). Boris Spivacow. Memoria de un sueño argentino. Buenos Aires: Colihue.

MENA SEGARRA, E.; PALOMEQUE, Á. L. y DELIO MACHADO, L. (2012). Historia de la educación uruguaya. Tomo 2, La educación uruguaya 1830-1886. Montevideo: Ediciones de la Plaza.

MICELI, S. (2003). Nacional estrangeiro, história social e cultural do modernismo artístico em São Paulo. San Pablo: Cia. das Letras.

(2012). Ensayos porteños. Borges, el nacionalismo y las vanguardias.

Bernal: Universidad Nacional de Quilmes.

MIGNOLO, W. (1998). Los cánones y (más allá de) las fronteras culturales (o ¿de quién es el canon del que hablamos?). En: SULLÁ, E. El canon literario. Madrid: Arco/Libros. 
MOLLIER, J.-Y. (2013). La lectura y sus públicos lectores en la Edad Contemporánea: ensayos de historia cultural en Francia. Buenos Aires: Ampersand.

MORETTI, F. (2015). Lectura distante. Buenos Aires: Fondo de Cultura Económica.

NAHUM, B. (Comp.) (2007). Estadísticas históricas del Uruguay (1900-1950). Montevideo: Universidad de la República.

(2011). Manual de historia del Uruguay, Montevideo, Ediciones de la Banda

Oriental.

(Dir.) (2003). Uruguay del siglo XX. La economía. Montevideo: Ediciones de la Banda Oriental.

(Dir.) (2008). Uruguay del siglo XX. La sociedad. Montevideo: Ediciones de la Banda Oriental.

OLIVERO, I. (1999). L'Invention de la collection. De la diffusion de la litttérature et des savoirs à la formation du citoyen au XIX siècle. París: Edition de L'Imec.

ONETTI, J. C. (1939, 28 de julio). «La piedra en el charco», Marcha, Montevideo.

ORTEGA Y GASSET, J. (1947). El tema de nuestro tiempo: el ocaso de las revoluciones, el sentido histórico de la teoría de Einstein. Buenos Aires: Espasa- Calpe.

PALOMEQUE, Á. (2012). Historia de la educación uruguaya, Tomo 3, La educación uruguaya 1886-1930. Montevideo: Ediciones de la Plaza.

PARADA, A. (1998). El mundo del libro y de la lectura durante la época de Rivadavia: una aproximación a través de los avisos de La Gaceta Mercantil (1823-1828). Buenos Aires: Universidad de Buenos Aires. (2007). Cuando los lectores nos susurran: libros, lecturas, bibliotecas, sociedad y prácticas editoriales en la Argentina. Buenos Aires: Instituto de Investigaciones Bibliotecológicas.

PEIRANO BASSO, L. (2001). Marcha de Montevideo y la formación de conciencia latinoamericana a través de sus cuadernos. Barcelona: Javier Vergara Editor.

PENCO, W. (1989). Diccionario de literatura uruguaya (2 vols.). Montevideo: Arca.

PERRET, E. (1923). Ensayo de Historia Patria: obra adaptada a los programas de Maestros y de la Universidad de Montevideo. Montevideo: Barreiro y Ramos.

PIVEL DEVOTO, J. E. (1945). Historia de la República Oriental del Uruguay 18301930. Montevideo: Editor Raúl Artagaveytia.

(1930). «La imprenta del Ejército Republicano, 1826-1828». Boletín del Instituto de Investigaciones Históricas, Tomo 11, Buenos Aires. 
y FURLONG CARDIFF, G. (1930). «Historia y Bibliografía de la Imprenta de la Provincia (1826-1828) y de la Imprenta San Carlos», en Revista del Instituto Histórico y Geográfico del Uruguay, Vol. VII, Montevideo.

(1930). «La imprenta del Ejército Republicano, 1826-1828», en Boletín del Instituto de Investigaciones Históricas, Tomo 11, Buenos Aires.

(1931). «La Misión de Nicolás Herrera a Río de Janeiro (1829-1830). Contribución al estudio de nuestra Historia Diplomática», en Revista del Instituto Histórico y Geográfico del Uruguay, Vol. VIII, Montevideo, Imprenta El Siglo Ilustrado.

(1932). «La Misión de Francisco J. Muñoz a Bolivia (1831-1835). Contribución al estudio de nuestra Historia Diplomática», en Revista del Instituto Histórico y Geográfico del Uruguay, Vol. IX, Montevideo, Imprenta El Siglo Ilustrado.

(1933a). «De nuestra Historia Diplomática», apartado del Boletín del Ministerio de Relaciones Exteriores, Montevideo, Imprenta El Siglo Ilustrado.

(1933b). «General Fructuoso Rivera», apartado del Boletín del Ministerio de Relaciones Exteriores, Vol. II, n 4-5. Montevideo, Imprenta El Siglo Ilustrado.

(1933c). «Los Corsarios de Artigas», apartado del Boletín del Ministerio de Relaciones Exteriores, Vol. II, n 4-5. Montevideo, Imprenta El Siglo Ilustrado.

(1933d). «Contribución Documental sobre nuestras relaciones Dipolomáticas y Comerciales con Gran Bretaña 1834-1835». en apartado del Boletín de Relaciones Exteriores, Vol. n 5-6, Montevideo, Imprenta El Siglo Ilustrado. (1934-1935). «El Instituto Histórico y Geográfico Nacional 1843 - 1845. documentos que sirven para su Historia Pública», en Revista del Instituto Histórico y Geográfico del Uruguay, Vol. XI, Montevideo, Imprenta El Siglo Ilustrado. (1937a) «El Congreso Cisplatino (1821)”, en apartado Revista del Instituto Histórico y Geográfico del Uruguay, Vol. XII, Montevideo, Imprenta El Siglo Ilustrado. (1937b). «El Congreso Cisplatino (1821)», en Revista del Instituto Histórico y Geográfico del Uruguay, Vol. XII, Montevideo, Imprenta El Siglo Ilustrado. (1938-1939). «Las ideas políticas de Bernardo P. Berro», en Revista Nacional, Vol. 129-134, Montevideo.

(1940a) «Exaltación de Artigas», en Revista Voluntad, Año VII, n8, Montevideo, Universidad del Trabajo.

(1940b). «Manuel José García y la Independencia del Uruguay», en Anuario de Historia Argentina, Volumen I, Buenos Aires. 
(1940c). «Las Imprentas Históricas que estuvieron al servicio de la causa de la Independencia 1826 - 1828», en Revista Voluntad, Año I, apartado 1, Montevideo, Universidad del Trabajo.

(1953). Prólogo. En: REYES, J. M. Descripción Geográfica del Territorio de la República Oriental del Uruguay. Montevideo: Ministerio de Instrucción Pública, Colección de Clásicos Uruguayos.

(1953b). Prólogo. En: RAMÍREZ, C. M. Artigas. Montevideo: Ministerio de Instrucción Pública, Colección de Clásicos Uruguayos.

(1957). Prólogo. En: DE MARÍA, I. Montevideo Antiguo. Montevideo: Ministerio de Instrucción Pública, Colección de Clásicos Uruguayos.

(1963). Prólogo. En: MAGARIÑOS CERVANTES, A. Estudios históricos, políticos y sociales sobre el Río de la Plata. Montevideo: Ministerio de Instrucción Pública y Seguridad Social, Colección de Clásicos Uruguayos.

(1963b). Prólogo. En: ZORRILLA DE SAN MARTÍN, J. La Epopeya de Artigas. Montevideo: Ministerio de Instrucción Pública y Seguridad Social, Colección de Clásicos Uruguayos.

(1965). Prólogo. En: BAUZÁ, F. (1965). Historia de la Dominación Española en el Uruguay, Tomo I (primera parte). Montevideo: Ministerio de Instrucción Pública y Seguridad Social, Colección de Clásicos Uruguayos.

(1965b). Prólogo. En: BAUZÁ, F. (1965). Historia de la Dominación Española en el Uruguay, Tomo I (segunda parte). Montevideo: Ministerio de Instrucción Pública y Seguridad Social, Colección de Clásicos Uruguayos.

(1965c). Prólogo. En: DE LA SOTA, J. M. Historia del territorio oriental del Uruguay. Montevideo: Ministerio de Instrucción Pública y Seguridad Social, Colección de Clásicos Uruguayos.

(1966). Prólogo. En: HERRERA Y OBES, M. y BERRO, B. P. El caudillismo y la revolución americana. Polémica. Montevideo: Ministerio de Instrucción Pública y Seguridad Social, Colección de Clásicos Uruguayos.

(1966b). Prólogo. En. BERRO, B. P. Escritos selectos. Montevideo:

Ministerio de Instrucción Pública y Seguridad Social, Colección de Clásicos Uruguayos.

(1968). Prólogo. En: DÍAZ, C. Memorias. Montevideo: Ministerio de Educación y Cultura, Colección de Clásicos Uruguayos.

(1972). Prólogo. En: BAUZÁ, F. Estudios Sociales y Económicos. Montevideo: Ministerio de Educación y Cultura, Colección de Clásicos Uruguayos. 
(1974). Advertencia. En: Archivo Artigas. Tomo XI. Montevideo: Ministerio de Educación y Cultura.

(1975). Prólogo. En: AA. VV. La independencia nacional. Montevideo:

Ministerio de Educación y Cultura, Colección de Clásicos Uruguayos.

(1981). Prologo. En: LIRA, L. El Parnaso Oriental o Guirnalda Poética de la República Uruguaya. Montevideo: Ministerio de Educación y Cultura, Colección de Clásicos Uruguayos.

y RANIERI, A. (1971). La Guerra Grande 1839-1851. Montevideo: Medina.

POZUELO YVANCOS, J. M. (1998). I. Lotman y el canon literario. En: SULLÁ, E. El canon literario. Madrid: Arco/Libros.

(2006). «Canon e historiografía literaria», en Iberoamericana. América Latina, España, Portugal, Vol. 6, n 22, Berlín, Ibero-Amerikanisches Institut.

QUIRING, D. (2016, 22 de marzo). «A la sombra del Paraíso», La Diaria, Montevideo.

RAMA, Á. (1969). «La conciencia crítica». En: Enciclopedia uruguaya, Fasc. 56, Montevideo, Editores Reunidos- Arca.

(1972). La generación crítica 1939-1969. Montevideo: Arca.

(1981). La Biblioteca Ayacucho como instrumento de integración cultural latinoamericana. Latinoamérica: Anuario de Estudios Latinoamericanos, (14). Ciudad de México: Universidad Nacional Autónoma de México.

(1971). «La generación crítica (1939-1969)», en: AA. VV., Uruguay hoy.

Buenos Aires: Siglo XXI.

(1961, 27 de enero). «La feria por dentro o el arte de vender uruguayos», Marcha, Montevideo.

(1971). La generación crítica (1939-1969). En: BENVENUTO, L. y otros.

Uruguay hoy, Buenos Aires, Siglo XXI.

(1998). La ciudad letrada. Montevideo: Arca.

(1966, 19 de agosto). «Los libros que el Uruguay produce», Marcha,

Montevideo.

(1961, 24 de marzo). «La biblioteca de un historiador», Marcha,

Montevideo.

(1955, 15 de julio). «Sobre el Manifiesto de los Escritores», Marcha,

Montevideo.

RAVIOLO, H. y ROCCA, P. (Dirs.) (1996). Historia de la literatura uruguaya contemporánea (2 vols.). Montevideo: Ediciones de la Banda Oriental. 
REAL DE AZÚA, C. (1973). El 900 y el modernismo en la literatura uruguaya. Montevideo: Fundación de Cultura Universitaria.

(1984). Ambiente espiritual del 900: Carlos Roxlo: un nacionalista popular.

Montevideo: Arca.

(1990). Los orígenes de la nacionalidad uruguaya. Montevideo: Arca.

(1964). Antología del ensayo uruguayo contemporáneo. Montevideo:

Publicaciones de la Universidad de la República.

RELA, W. (1963). Contribución a la bibliografía de la literatura uruguaya: 1835-1962. Montevideo: FHCE, Universidad de la República.

(1986). Diccionario de escritores uruguayos. Montevideo: Ediciones de la Plaza.

REYES ABADIE, W., y otros (1979). Crónica general del Uruguay, 7 tomos. Montevideo: Ediciones de la Banda Oriental.

REYLES, C. (1931). Historia sintética de la literatura uruguaya: plan aprobado por la comisión nacional del centenario. Montevideo: Alfredo Vila.

RIBADERO, M. (2016). Editoriales, libros e ideas. La «Izquierda Nacional» de Jorge Abelardo Ramos a principios de los años sesentas [Mimeo]. Buenos Aires: Universidad de Buenos Aires.

RIBEIRO, A. (1991). Historia e historiadores nacionales (1940-1990). Del ensayo sociológico a la historia de las Mentalidades. Montevideo: Ediciones de la Plaza. (1994). Historiografía nacional (1880-1940). De la épica al ensayo sociológico. Montevideo: Ediciones de la Plaza.

RICOEUR, P. (1999). Historia y narratividad. Barcelona: Paidós. (2002). La interpretación de la narración. Pamplona: Eunsa. (2010). La memoria, la historia, el olvido. Madrid: Editorial Trotta.

(2008). Hermenéutica y acción: de la hermenéutica del texto a la hermenéutica de la acción. Buenos Aires: Prometeo.

(2013). La historia, la memoria, el olvido. Buenos Aires: Fondo de Cultura Económica.

RILLA, J. (2008). La actualidad del pasado. Usos de la historia en la política de partidos del Uruguay (1942-1972). Montevideo: Debate.

ROBINSON, L. (1998). Traicionando nuestro texto. Desafíos feministas al canon literario. En: SULLÁ, E. El canon literario. Madrid: Arco/Libros.

ROCCA, Pablo (2003). Poesía y política en el siglo XIX, Montevideo, Ediciones de la Banda Oriental. 
(2006). Ángel Rama, Emir Rodríguez Monegal y el Brasil: dos caras de un proyecto latinoamericano. Montevideo: Ediciones de la Banda Oriental.

(1992). 35 años en Marcha (Crítica y literatura en Marcha y en el Uruguay 1939-1974). Montevideo: Intendencia Municipal de Montevideo- División Cultura.

(2009). Revistas culturales en el Río de la Plata: campo literario, debates, documentos, índices (1942-1964). Montevideo: Universidad de la República.

(2012). «Editar en el Novecientos (Orsini Bertani y algunos problemas de las culturas material y simbólica)», en Revista Orbis Tertius, Vol. 17, $\mathrm{n}^{\circ}$ 18, La Plata, Universidad Nacional de La Plata.

RODRÍGUEZ MONEGAL, E. (1966). Literatura uruguaya del medio siglo. Montevideo: Alfa.

(1953, 13 de febrero). «El escritor y el problema editorial en nuestro país», Marcha, Montevideo.

(1954, 24 de diciembre). «¿A dónde va la Literatura Nacional? Reflexiones de fin de año», Marcha, Montevideo.

(1961, 6 de setiembre). «Aventura del libro uruguayo», Revista Reporter,

Montevideo.

ROJAS, R. (2000). Un banquete canónico. Ciudad de México: Fondo de Cultura Económica.

ROXLO, C. (1912). Historia crítica de la literatura uruguaya, 6 tomos. Montevideo: Barreiro y Ramos.

SANSÓN CORBO, T. (2006). La construcción de la nacionalidad oriental. Estudios de historiografia colonial. Montevideo: FHCE, Universidad de la República.

(2006-2007). «La influencia argentina en la configuración de la historiografía uruguaya. Estudio de caso: Francisco Bauzá», en Trabajos y Comunicaciones, ${ }^{\circ}$ 32-33, La Plata, UNLP.

(2001-2002). «Independencia y nación en las obras de Efraím Cardozo y Juan Pivel Devoto. Ensayo de historiografía comparada», en Revista de Estudios Paraguayos, $n^{\circ}$ 1-2, Asunción del Paraguay, Centro de Estudios Antropológicos de la Universidad Católica de Asunción.

(2011). El espacio historiográfico rioplantense y sus dinámicas (siglo XIX).

La Plata: Instituto Cultural de la Provincia de Buenos Aires.

SANSONE, E. (1964). Prólogo. En: LUSSICH, A. Los tres gauchos orientales. Montevideo: Ministerio de Instrucción Pública y Seguridad Social, Colección de Clásicos Uruguayos. 
SCARONE, A. (1937). Uruguayos contemporáneos. Montevideo: Barreiro y Ramos.

SHAW, Donald L. (1999). Nueva narrativa hispanoamericana: boom, posboom, posmodernismo, Madrid, Ediciones Cátedra.

SIGAL, Silvia (1991). Intelectuales y poder en la década del sesenta, Buenos Aires, Puntosur.

SLOTERDIJK, P. (2000). Normas para el parque humano. Una respuesta a la carta sobre el humanismo de Heidegger. Madrid: Siruela.

SOLER, L. (1993). La historiografía uruguaya contemporánea. Aproximación a un estudio. Montevideo: Ediciones de la Banda Oriental.

SOMMER, D. (2010). Un romance irresistible. Las ficciones fundacionales de América Latina. En BHABHA, H. K. (Comp.). Nación y narración. Buenos Aires: Siglo XXI.

(2004). Ficciones fundacionales: las novelas nacionales de América Latina, Bogotá: Fondo de Cultura Económica.

SORÁ, G. (2010). Misión de la edición para una cultura en crisis. El Fondo de Cultura Económica y el americanismo en Tierra Firme. En: ALTAMIRANO, C. (Dir.). Historia de los intelectuales en América Latina. Buenos Aires: Katz.

(2017). Editar desde la izquierda en América Latina. La agitada historia del Fondo de Cultura Económica y de Siglo XXI. Buenos Aires: Siglo XXI.

SOSNOWSKI, S. (Ed.) (1999). La cultura de un siglo. América Latina en sus revistas. Buenos Aires: Alianza Editorial.

SPERONI VENER, J. (1989). «Las ediciones furtivas de Claudio García», en: Revista de la Biblioteca Nacional, $\mathrm{n}^{\circ} 26$, Montevideo.

SUBERCASEAUX, B. (2000). Historia del libro en Chile (Alma y Cuerpo). Santiago de Chile: LOM.

SULLÁ, E. (1998). El canon literario. Madrid: Arco/Libros.

TODOROV, T. (Comp.) (2008). Teoría de literatura de los formalistas rusos. Buenos Aires: Siglo XXI.

(2010). Nosotros y los otros. Reflexión sobre la diversidad humana, Madrid:

Siglo XXI.

TORRES TORRES, A. (2012). Lectura y sociedad en los sesenta: a propósito de Alfa y Arca. Montevideo: Yaugurú.

TRAVERSO, E. (2012). La historia como campo de batalla. Interpretar las violencias del siglo XX. Buenos Aires: Fondo de Cultura Económica. 
VALINOTI, B. (2013). Una nueva Serendipia: David Peña y la Biblioteca Internacional de Obras Famosas. XIV Jornadas Interescuelas/Departamentos de Historia, Mendoza, Departamento de Historia de la Facultad de Filosofía y Letras, Universidad Nacional de Cuyo.

VARGAS LLOSA, M. (1971). García Márquez: historia de un deicidio. Lima: Barral Editores.

VERDESIO, G. (1995). Una ausencia en el canon: los discursos coloniales sobre el Uruguay en el marco de la historiografía literaria uruguaya y los estudios coloniales latinoamericanos. Revista Iberoamericana, Pittsburgh, University of Pittsburgh Press, LXI, 170171.

VEYNE, P. (1984). Cómo se escribe la historia. Foucault revoluciona la historia. Madrid: Alianza.

(2014). Foucault. Pensamiento y vida. Buenos Aires: Paidós.

VIDAURRETA, A. (2001). Conversaciones con Juan E, Pivel Devoto. Montevideo: Ediciones de la Plaza.

VISCA, A. S. (1979). La mirada crítica y otros ensayos. Montevideo: Academia Nacional de Letras.

WELLEK, René; WARREN, Austin (1974). Teoría literaria, Madrid, Gredos.

WHITE, H. (1992). Metahistoria: la imaginación histórica en la Europa del siglo XIX. México: Fondo de Cultura Económica.

WILLIAMS, Raymond (1994). Sociología de la cultura, Barcelona, Paidós.

ZAVALA MUNIZ, J. (1953). La Colección de Clásicos Uruguayos. En: RAMÍREZ, C. M. Artigas. Montevideo: Ministerio de Instrucción Pública, Colección de Clásicos Uruguayos.

ZANETTI, S. (1998). Apuntes acerca del canon latinoamericano. En: CELLA, S. (Comp.). Dominios de la literatura. Acerca del canon. Buenos Aires: Losada.

ZUBILlaGA, C. (2002). Historia e Historiadores en el Uruguay del Siglo XX. Montevideo: Librería de la Facultad de Humanidades y Ciencias de la Educación. (1999). «Libreros y editores gallegos en Montevideo», en: Madrygal: Revista de Estudios Gallegos, n², Madrid- Galicia. (1996). Los desafios del historiador. Montevideo: Universidad de la República.

ZUM FELDE, A. (1921). Crítica de la literatura uruguaya. Montevideo: Maximinio García.

(1930). Proceso intelectual del Uruguay: crítica de su literatura, tomo 2. Montevideo: Imprenta Nacional Colorada. 
(1930b). Proceso intelectual del Uruguay: crítica de su literatura, tomo 3.

Montevideo: Imprenta Nacional Colorada.

(1944). Prólogo. En: ZORRILLA DE SAN MARTÍN, J. Tabaré. Buenos

Aires: Ángel Estrada y Cía S.A.

(1956). Prólogo. En: ZORRILLA DE SAN MARTÍN, J. Tabaré. Montevideo: Ministerio de Instrucción Pública, Colección de Clásicos Uruguayos. 